\title{
Effects of Morrow's honeysuckle control and the impact of the shrub on invertebrates at Fort Necessity National Battlefield, Pennsylvania
}

\author{
Jason Patrick Love \\ West Virginia University
}

Follow this and additional works at: https://researchrepository.wvu.edu/etd

\author{
Recommended Citation \\ Love, Jason Patrick, "Effects of Morrow's honeysuckle control and the impact of the shrub on \\ invertebrates at Fort Necessity National Battlefield, Pennsylvania" (2006). Graduate Theses, Dissertations, \\ and Problem Reports. 2362. \\ https://researchrepository.wvu.edu/etd/2362
}

This Thesis is protected by copyright and/or related rights. It has been brought to you by the The Research Repository @ WVU with permission from the rights-holder(s). You are free to use this Thesis in any way that is permitted by the copyright and related rights legislation that applies to your use. For other uses you must obtain permission from the rights-holder(s) directly, unless additional rights are indicated by a Creative Commons license in the record and/ or on the work itself. This Thesis has been accepted for inclusion in WVU Graduate Theses, Dissertations, and Problem Reports collection by an authorized administrator of The Research Repository @ WVU. For more information, please contact researchrepository@mail.wvu.edu. 


\title{
Effects of Morrow's Honeysuckle Control and the Impact of the Shrub on Invertebrates at Fort Necessity National Battlefield, Pennsylvania
}

\author{
Jason Patrick Love
}

\author{
Thesis submitted to the \\ Davis College of Agriculture, Forestry, and Consumer Sciences \\ at West Virginia University \\ in partial fulfillment of the requirements \\ for the degree of \\ Master of Science \\ in \\ Wildlife and Fisheries Resources
}

James T. Anderson, Ph.D., Major Advisor James B. McGraw, Ph.D., Committee Member Constance A. Ranson, M.S., Committee Member

Division of Forestry and Natural Resources

\author{
Morgantown, West Virginia \\ 2006
}

Keywords: arthropods, glyphosate, herbaceous layer, herbicide, invasive, Lonicera morrowii, meadow, restoration, southern arrowwood, understory, Viburnum recognitum

Copyright 2006 Jason P. Love 


\section{ABSTRACT \\ Effects of Morrow's Honeysuckle Control and the Impact of the Shrub on Invertebrates at Fort Necessity National Battlefield, Pennsylvania}

\section{Jason Patrick Love}

Lonicera morrowii (Morrow's honeysuckle) dominates a degraded meadow at Fort Necessity National Battlefield, Pennsylvania, U.S.A. We tested four removal methods of Morrow's honeysuckle during spring and autumn 2004. Cut, stump application of $20 \%$ glyphosate, and mechanical removal in autumn were not successful ( $<47 \%$ reduction), while mechanical removal in spring and foliar application of $2 \%$ glyphosate were somewhat successful ( $>66 \%$ reduction). We used a modified leaf blower to sample invertebrates at our site. Invertebrate biomass was lowest within the native shrub, Viburnum recognitum (southern arrowwood) $(p<0.05)$. Biomass of larval leaf chewers was highest in the native shrub. Invertebrate abundance, biomass, and richness were reduced under dense thickets of Morrow's honeysuckle $(p<0.05)$, due to low amount of herbaceous cover beneath the shrubs. The amount of leaf area consumed by herbivores was 10 times more on the native shrub. Overall, our findings reveal that the exotic shrubs negatively impact invertebrate communities. 


\section{ACKNOWLEDGMENTS}

Funding for this research was provided by the National Park Service and Fort Necessity National Battlefield (FONE). I thank my advisor, Jim Anderson, for providing me with the opportunity to work on this project, giving me the freedom to select portions of the project for my thesis research, and for being a great mentor and friend. A special thanks is extended to Connie Ranson, Natural Resource Specialist at FONE, for her unwavering support and guidance. I thank Committee member Dr. Jim McGraw for advice on study design and statistics and for proofing earlier drafts of this manuscript. Dr. Jim Rentch, Dr. Linda Butler, Dr. George Seidel, A.B. Billings, and Dr. Stewart Welsh also provided advice on study design and statistics. Mike Henderson provided generous GIS support, particularly at the beginning of the project. Bill Grafton spent many hours in the field and in the lab helping us to identify plants and gave helpful advice on restoration of native vegetation after Morrow's honeysuckle is removed from the study site.

I was fortunate to have Jennifer Edalgo as my co-worker on this project; her smile, boundless energy, enthusiasm, and strong work ethic made field and office work something to look forward to (or at least not run away from). My wonderful wife, Jennifer Love, spent two summers (her summer vacation) crawling through thickets of Morrow's honeysuckle and sorting seemingly endless samples of invertebrates in the lab. Her patience, love, and sacrifice made these two years and 3 months of balancing a long-distance marriage and graduate school bearable. In addition, Mark Hepner, Jason Alexander, and Robbie Edalgo contributed an enormous amount of their time in the field and lab; without their hard work and attention to detail, this project would not have been possible. Tammy Webster and the WVU Rumen Fermentation lab performed lab analysis of TNC concentrations and leaf litter nutrients. Vicki 
Kondo gladly identified invertebrates that were beyond our ability to key-out. Chris Dacko and the WVU Chemistry Department provided dry ice for the TNC root collections. Paul Ludrosky cut the cover board "cookies" for our project and made sure our vehicles were in proper working order. Additional field and lab assistance was provided by: LeAnne Bonner, Ben Hoksch, Lisa Tager, Bridget Crokus, Valerie Wells, Amanda Strippel, Tom Swain, Joe Osbourne, Ed Ralph, Diane Ralph, Anthony Williams, Donna Hartman, Ryan Utz, Andrian Sherman, Ketan Tatu, Kelly Perkins, Sarah McClurg, Walter Veselka, Alida Clarke, and the 2005 Student Conservation Association crew (Hillary Thomson, James Rutherford, Abbie Paris, Julia Marder, Torie Neff, Jessica Zelle, Ray Chan, Dan Farrell, and Dalton Dwyer).

Finally, I thank my family and friends for their encouragement, love, and support. Thank you! 


\section{TABLE OF CONTENTS}

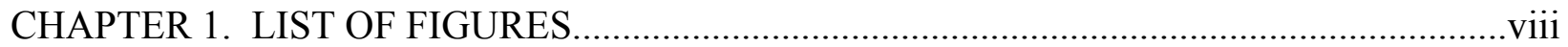

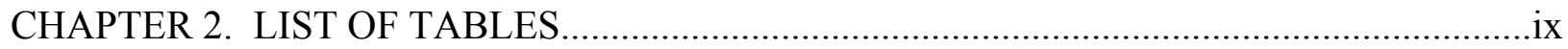

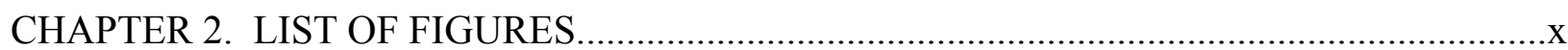

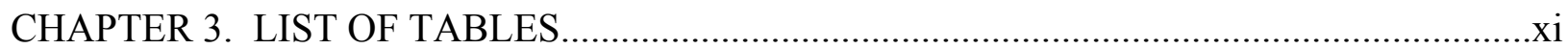

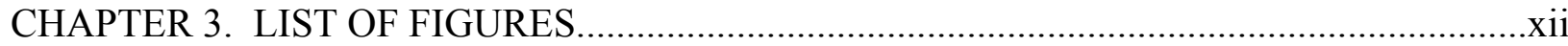

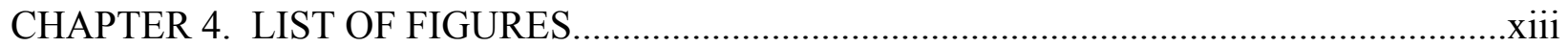

LIST OF APPENDICES............................................................................................

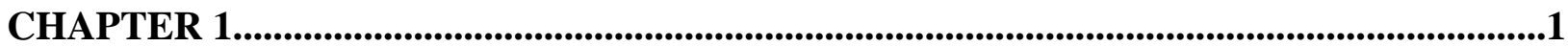

INTRODUCTION, LITERATURE REVIEW, AND JUSTIFICATION FOR

RESTORATION OF A DEGRADED MEADOW INFESTED WITH LONICERA

MORROWII (MORROW'S HONEYSUCKLE) AT FORT NECESSITY NATIONAL

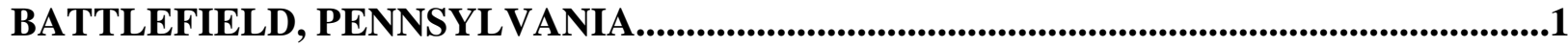

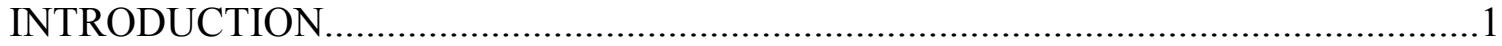

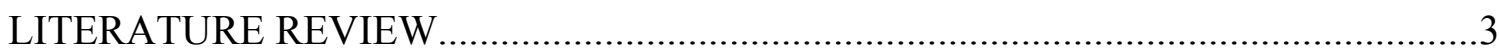

Description of Exotic Bush Honeysuckles..................................................... 3

Habitat and Range of Morrow's Honeysuckle..................................................

Reproduction and Dispersal of Exotic Bush Honeysuckles.................................6

Phenology of Exotic Bush Honeysuckles..............................................................

Wildlife Use of Exotic Bush Honeysuckles........................................................

Ecological Impacts of Exotic Bush Honeysuckles.............................................

Pests and Diseases of Exotic Bush Honeysuckles...............................................13

Control and Management of Exotic Bush Honeysuckles...................................14

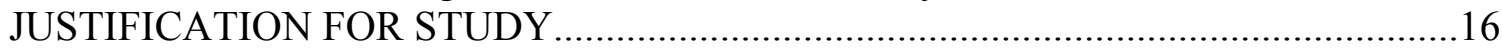

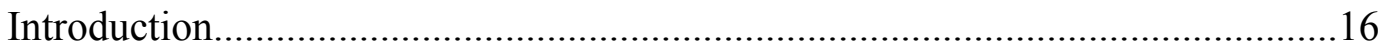

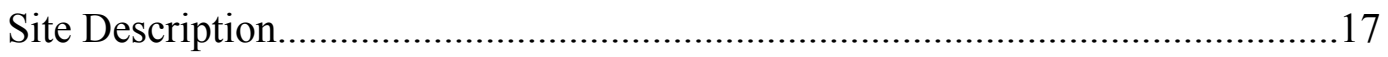

Objectives and Hypotheses................................................................................19

Relating total non-structural carbohydrates to plant phenological stages..............................................................................................19

Comparing abundance, biomass, and richness of invertebrates found on

Morrow's honeysuckle to invertebrates found on a native shrub.............19

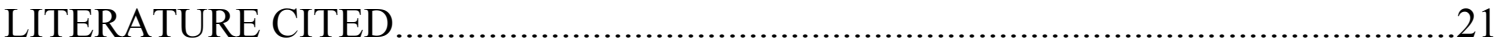

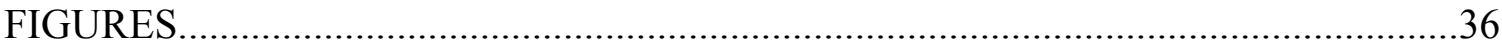

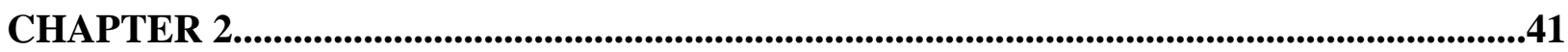

SEASONAL EFFECTS OF FOUR REMOVAL METHODS ON THE INVASIVE LONICERA MORROWII (MORROW'S HONEYSUCKLE) AND INITIAL RESPONSES OF UNDERSTORY PLANTS IN A SOUTHWESTERN PENNSYLVANIA OLD

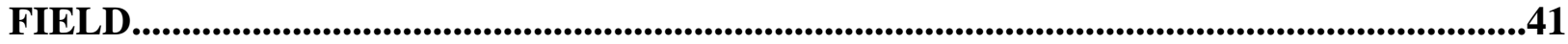

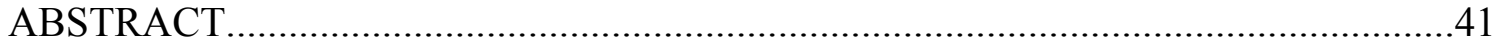

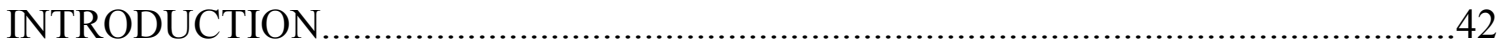

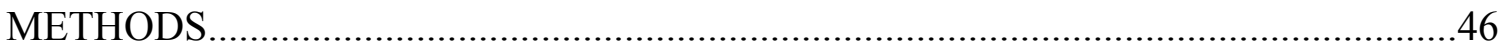




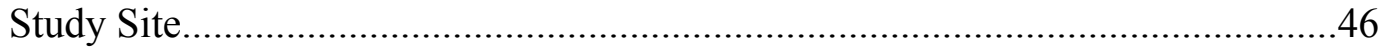

Total Nonstructural Carbohydrates.................................................................47

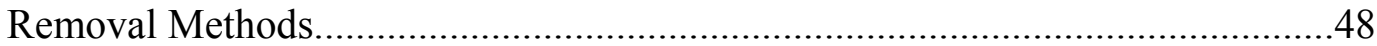

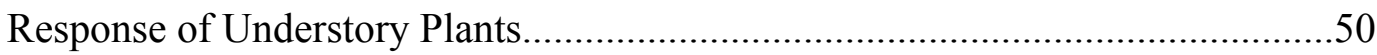

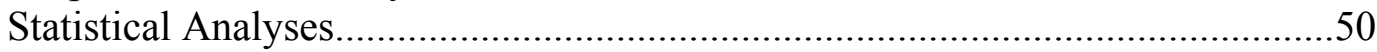

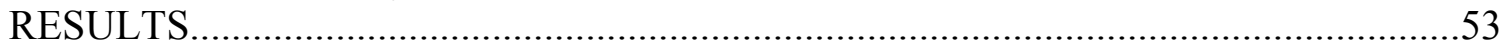

Total Nonstructural Carbohydrates..................................................................53

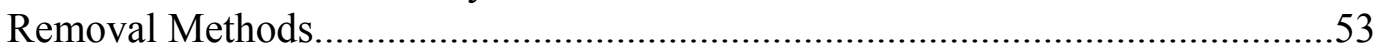

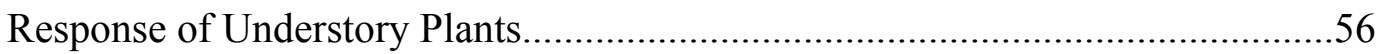

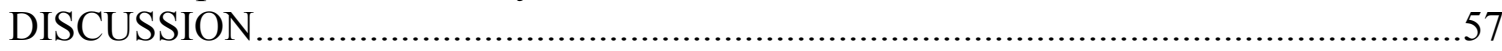

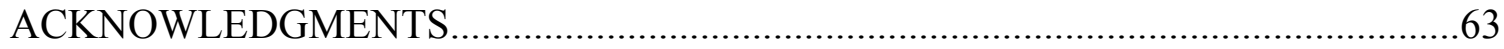

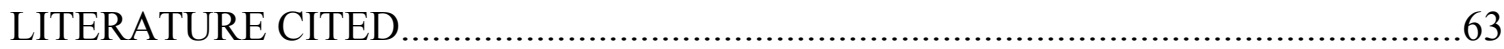

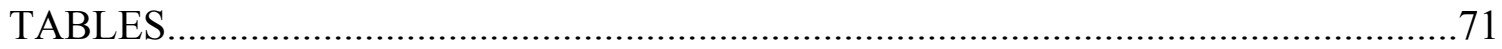

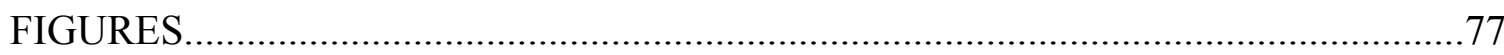

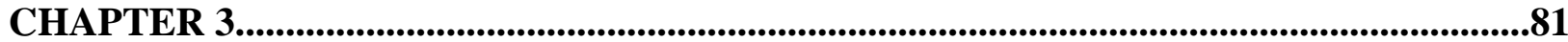

EFFECTS OF AN EXOTIC INVASIVE SHRUB (LONICERA MORROWII) ON INVERTEBRATE ABUNDANCE, BIOMASS, AND RICHNESS............................................81

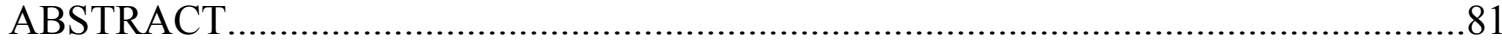

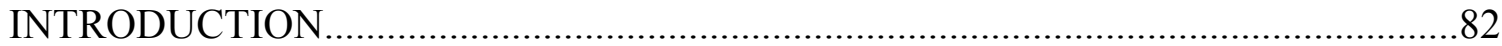

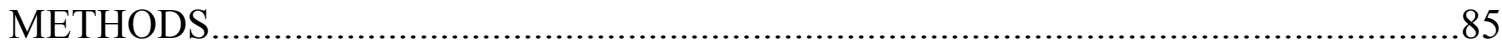

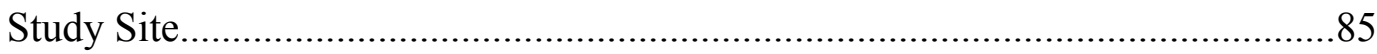

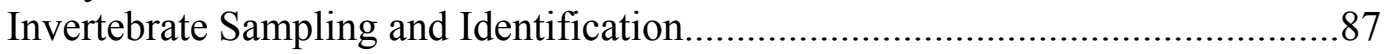

Factors Influencing Ground-dwelling Invertebrates............................................88

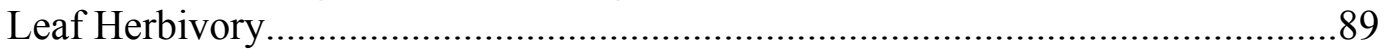

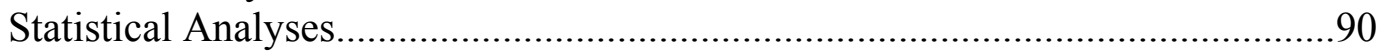

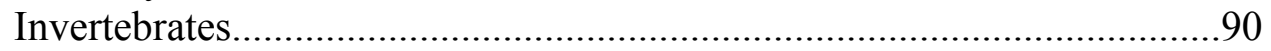

Factors Influencing Ground-dwelling Invertebrates.................................90

Leaf Herbivory..............................................................................92

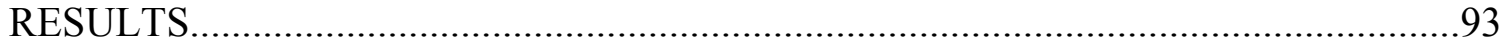

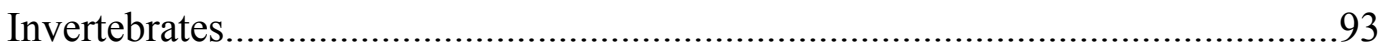

Factors Influencing Ground-dwelling Invertebrates........................................94

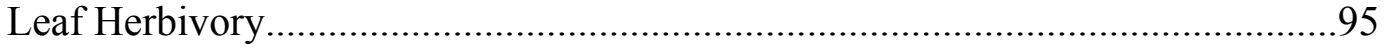

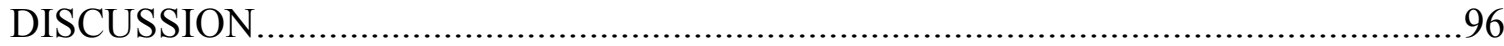

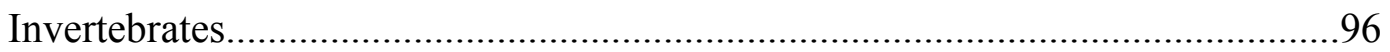

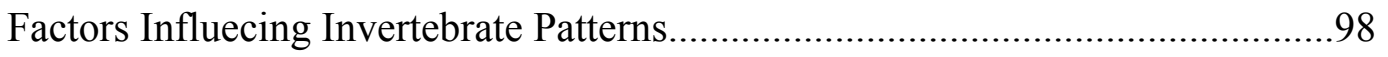

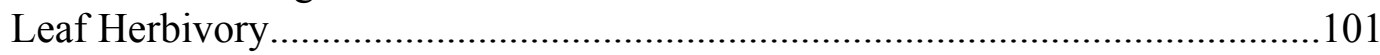

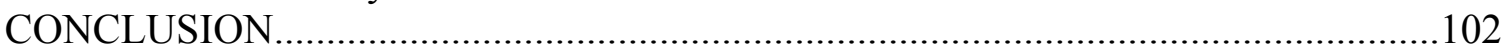

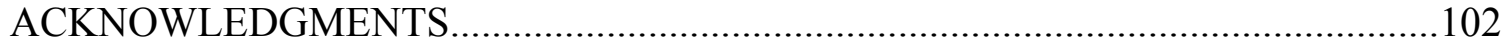

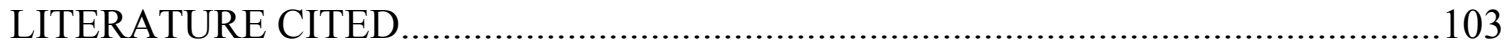

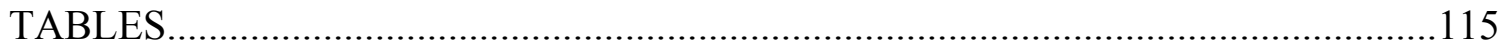

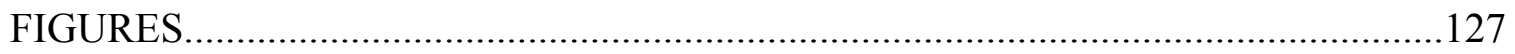


CONCLUSION AND MANAGEMENT IMPLICATIONS FOR RESTORATION OF A DEGRADED MEADOW INFESTED WITH AN INVASIVE SHRUB, LONICERA MORROWII (MORROW'S HONEYSUCKLE) ....................................................................130

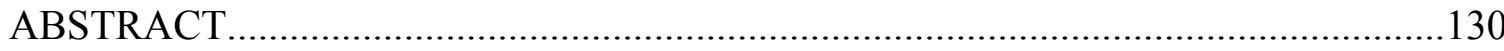

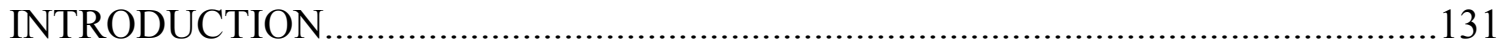

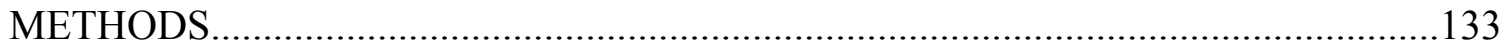

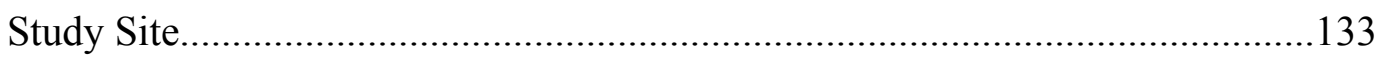

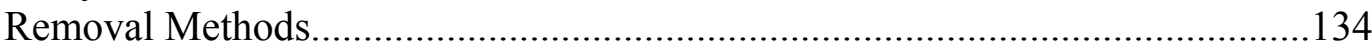

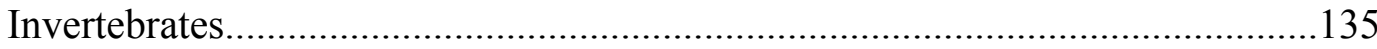

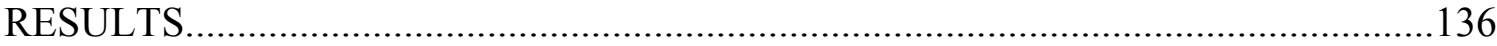

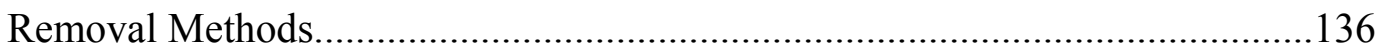

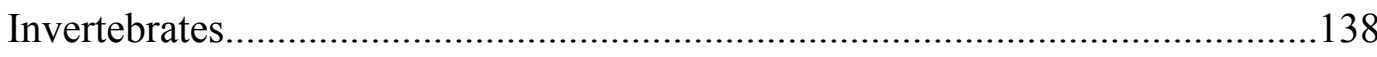

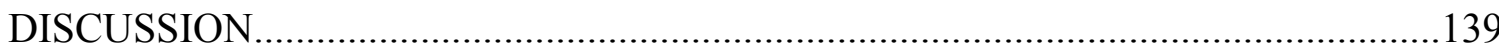

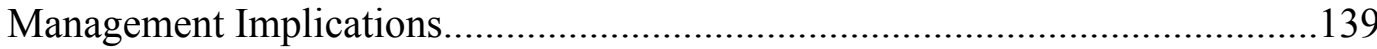

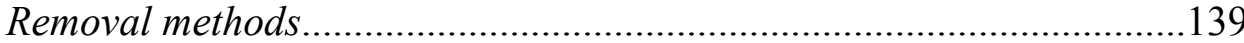

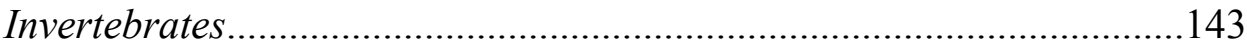

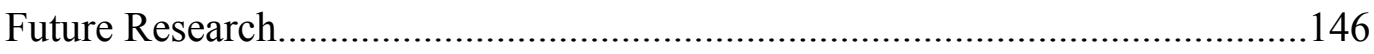

Morrow's honeysuckle and its relatives.................................................146

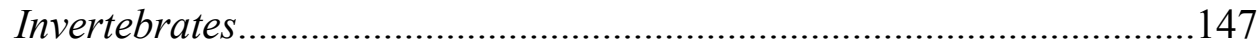

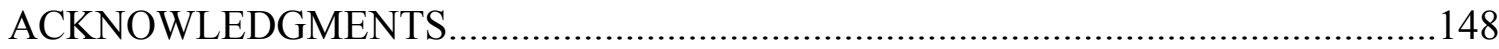

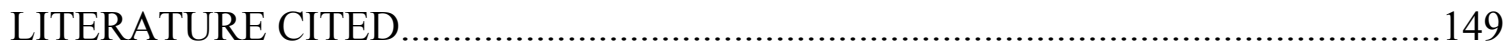

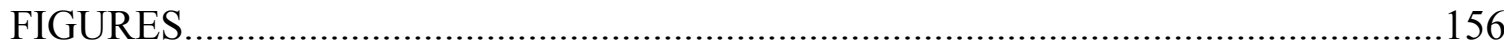

APPENDICES.....................................................................................................................159

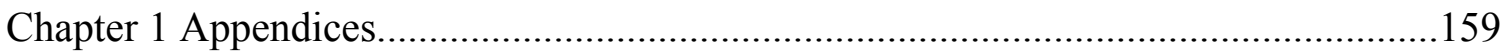

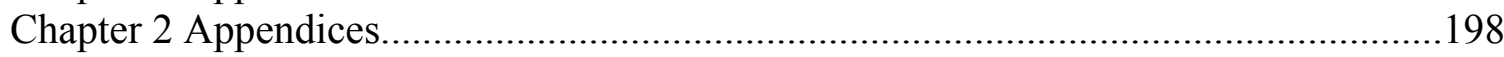




\section{CHAPTER 1. LIST OF FIGURES}

Figure 1. Lonicera morrowii (Morrow's honeysuckle) blooms May-June and has white flowers that later fade to yellow (top). When mature, the paired fruits of Morrow's honeysuckle are

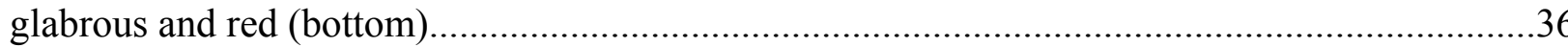

Figure 2. Fort Necessity National Battlefield lies in Fayette County, southwestern Pennsylvania

Figure 3. The study site is located within the 350.5 ha Fort Necessity National Battlefield. The site lies adjacent to the replica of Fort Necessity, the central historical attraction at the park......38

Figure 4. The study site overlooks the replica of Fort Necessity. Morrow's honeysuckle dominates the study site and has impeded natural regeneration of the hardwood forest........

Figure 5. An aerial photograph (circa 1985) reveals that the study area contained few shrubs (top). However, when mowing ceased, Morrow's honeysuckle invaded the site and now dominates the study area, as seen from this 2003 aerial photo (bottom). Yellow arrows point to an isolated spruce stand for reference. 


\section{CHAPTER 2. LIST OF TABLES}

Table 1. Mean ( \pm SE) Morrow's honeysuckle cover, stem density, shrub density, and native shrub density per $5 \times 5$-m plot differed between pre- and post-treatment at Fort Necessity National Battlefield, Pennsylvania, U.S.A

Table 2. Foliar application of herbicide was the cheapest treatment method, while stump application of herbicide was the most expensive method to control Morrow's honeysuckle growing in a degraded meadow at Fort Necessity National Battlefield, Pennsylvania, U.S.A.....73

Table 3. Mean $( \pm \mathrm{SE})$ herbaceous variables per $5 \times 5$-m plot differed between pre- and posttreatment removal of Morrow's honeysuckle and among post-treatment methods at Fort Necessity National Battlefield, Pennsylvania, U.S.A 


\section{CHAPTER 2. LIST OF FIGURES}

Figure 1. Our study site at Fort Necessity National Battlefield, Pennsylvania, U.S.A. was characterized by a dense monoculture of Lonicera morrowii (Morrow's honeysuckle); prior to treatment, we estimated that there were approximately 176,000 live stems/ha.

Figure 2. Total nonstructural carbohydrates for Morrow's honeysuckle were lowest in May at Fort Necessity National Battlefield, Pennsylvania, U.S.A., after the leaves were fully emerged; TNC levels were highest in October, as the leaves were beginning to senesce $(p<0.05) \ldots \ldots \ldots \ldots . .78$

Figure 3. Mean ( \pm SE) post-treatment percent cover, stem density, and shrub density of Morrow's honeysuckle differed based on treatment and season at Fort Necessity National Battlefield, Pennsylvania. Means with different letters are significantly different, based on Duncan's multiple range tests $(p<0.05)$.

Figure 4. Mean ( \pm SE) exotic herbaceous plant cover and Floristic Quality Index (FQI) scores differed based on treatment and season at Fort Necessity National Battlefield, Pennsylvania. Means with different letters are significantly different, based on Duncan's multiple range tests $(p<0.05)$ 


\section{CHAPTER 3. LIST OF TABLES}

Table 1. Biotic and abiotic habitat parameters, measured in the understory of a degraded meadow, included in linear regression models explaining microhabitat relationships of invertebrate abundance and biomass at Fort Necessity National Battlefield, Pennsylvania, U.S.A

Table 2. Linear regression models explaining influence of biotic and abiotic environmental variables on patterns of invertebrate abundance under different shrub types during different months in a degraded meadow at Fort Necessity National Battlefield, Pennsylvania, U.S.A. Model rankings were based on Akaike's Information Criterion corrected for small sample size $\left(\mathrm{AIC}_{\mathrm{c}}\right)$

Table 3. Linear regression models explaining influence of biotic and abiotic environmental variables on patterns of invertebrate biomass under different shrub types during different months in a degraded meadow at Fort Necessity National Battlefield, Pennsylvania, U.S.A. Model rankings were based on Akaike's Information Criterion corrected for small sample size $\left(\mathrm{AIC}_{\mathrm{c}}\right)$

Table 4. The five most common invertebrates ( $\geq 2 \mathrm{~mm}$ in length) collected from the shrub strata of three shrub types $(n=45)$ based on abundance (total number of invertebrates per Family) and biomass (total dry weight (mg)) at Fort Necessity National Battlefield, Pennsylvania, U.S.A...118

Table 5. Mean ( \pm SE) abundance, biomass (dry weight (mg)), and richness (Family or lowest taxonomic group) of invertebrates ( $\geq 2 \mathrm{~mm}$ in length) sampled within the shrub strata based on shrub type and month at Fort Necessity National Battlefield, Pennsylvania, U.S.A.....

Table 6. The five most common invertebrates ( $\geq 2 \mathrm{~mm}$ in length) collected from the understory of four shrub types $(n=45)$ based on abundance (total number of invertebrates per Family) and biomass (total dry weight (mg)) at Fort Necessity National Battlefield, Pennsylvania, U.S.A...120

Table 7. Mean ( \pm SE) abundance, biomass (dry weight (mg)), and richness (Family or lowest taxonomic group) of invertebrates ( $\geq 2 \mathrm{~mm}$ in length) sampled in the understory based on shrub type and month at Fort Necessity National Battlefield, Pennsylvania, U.S.A.

Table 8. Mean $( \pm \mathrm{SE})$ values of microhabitat variables recorded under Morrow's honeysuckle shrubs (L), southern arrowwood shrubs (V), dense thickets of Morrow's honeysuckle (X), and open plots with no shrub cover $(\mathrm{O})$ based on month at Fort Necessity National Battlefield, Pennsylvania, U.S.A

Table 9. Morrow's honeysuckle and southern arrowwood mean $( \pm \mathrm{SE})$ percent of leaves with evidence of herbivory, leaf area consumed $\left(\mathrm{cm}^{2}\right)$, and herbivory rank at Fort Necessity National Battlefield, Pennsylvania, U.S.A. 


\section{CHAPTER 3. LIST OF FIGURES}

Figure 1. Mean ( \pm SE) ground-dwelling invertebrate abundance and richness differed depending on shrub understory type and month at Fort Necessity National Battlefield, Pennsylvania. Means with different letters are significantly different, based on Duncan's multiple range tests $(p<0.05)$

Figure 2. Ground-dwelling mean invertebrate abundance and biomass over all months was positively related to percent herbaceous cover, which in turn was regulated by shrub type $(\mathrm{L}=$ lone Morrow's honeysuckle; V = lone southern arrowwood; X = dense thickets of Morrow's honeysuckle; and $\mathrm{O}=$ open plots with no overstory) within a degraded meadow at Fort Necessity National Battlefield, Pennsylvania, U.S.A.

Figure 3. Mean $( \pm \mathrm{SE})$ percent of leaves with evidence of herbivory and leaf rank differed between shrub type and seasons at Fort Necessity National Battlefield, Pennsylvania. Means with different letters are significantly different, based on Duncan's multiple range tests $(p<0.05)$ 


\section{CHAPTER 4. LIST OF FIGURES}

Figure 1. The "wetland" and "control" areas should be managed as quality early successional habitat, while the "treatment" area should be managed to facilitate the growth of a mature forest.

Figure 2. Approximately 2.75 ha of thinly scattered Morrow's honeysuckle should be treated by mechanically removing the shrubs. The study area outside the mechanical removal area should be treated with a foliar application of glyphosate in October, followed by bush-hogging in

May.....

Figure 3. Conceptual pathway to achieve desired conditions in a degraded meadow dominated by Morrow's honeysuckle at Fort Necessity National Battlefield, Pennsylvania, U.S.A...........154 


\section{LIST OF APPENDICES}

Appendix Ia. Results for the tests for homogeneity of slope for covariates (pre-treatment shrub metrics) versus the dependent variables (post-treatment shrub metrics) prior to running analysis of covariance for Morrow's honeysuckle and native shrubs at Fort Necessity National Battlefield, Pennsylvania, U.S.A.

Appendix IIa. Number of Morrow's honeysuckle root samples per phenological stage and their mean $( \pm \mathrm{SE})$ percent total nonstructural carbohydrates levels at Fort Necessity National Battlefield, Pennsylvania, U.S.A. from March 2004 - February 2005.

Appendix IIIa. Morrow's honeysuckle and $\mathrm{F}$ and $p$ values for pre- and post-treatment cover, stem density, shrub density, and native shrub density at Fort Necessity National Battlefield, Pennsylvania, U.S.A.

Appendix IVa. Morrow's honeysuckle $\mathrm{t}$ and $p$ values for pre- and post-treatment cover, stem density, shrub density, and native shrub density comparisons (paired t-tests) at Fort Necessity National Battlefield, Pennsylvania, U.S.A.

Appendix Va. Mean ( \pm SE) Morrow's honeysuckle cover, stem density, shrub density, and native shrub density per $5 \times 5$-m plot differed between pre- and post-treatment at Fort Necessity National Battlefield, Pennsylvania, U.S.A.

Appendix VIa. The majority of Morrow's honeysuckle post-treatment live stems were classified as sprouts at Fort Necessity National Battlefield, Pennsylvania, U.S.A. during the 2005 field season.

Appendix VIIa. We identified, recorded frequency, determined mean ( \pm SE) number of live stems and plants per plot, estimated mean $( \pm \mathrm{SE})$ number of live stems and plants per hectare, and determined mean $( \pm \mathrm{SE})$ basal diameter of live stems of 21 woody species within $455 \times 5-\mathrm{m}$ plots prior to testing Morrow's honeysuckle removal methods at Fort Necessity National Battlefield, Pennsylvania, U.S.A. Bold-faced species are exotic.

Appendix VIIIa. After Morrow's honeysuckle removal methods were completed, we identified, determined frequency, mean $( \pm \mathrm{SE})$ number of live stems and plants per plot, and mean $( \pm \mathrm{SE})$ number of live stems and plants per hectare for each season-treatment combination during the summer 2005 at Fort Necessity National Battlefield, Pennsylvania, U.S.A. Bold-faced species are exotic.

Appendix IXa. Following treatment, Morrow's honeysuckle still accounted for a large proportion of all live stems within a degraded meadow at Fort Necessity National Battlefield, Pennsylvania, U.S.A. in 2005 
Appendix Xa. F and $p$ values for herbaceous variables prior to and following the removal of Morrows honeysuckle at Fort Necessity National Battlefield, Pennsylvania, U.S.A.

Appendix XIa. T and $p$ values for pre- and post-treatment herbaceous community quality comparisons (paired t-tests) at Fort Necessity National Battlefield, Pennsylvania, U.S.A...

Appendix XIIa. Post-treatment mean ( \pm SE) herbaceous measurements for $455 \times 5$-m plots under different seasons and treatments were recorded at Fort Necessity National Battlefield, Pennsylvania, U.S.A. in July $2005 .$.

Appendix XIIIa. We calculated mean percent cover and percent frequency of 93 herbaceous species during our pre-treatment surveys in May 2004 and August 2004 within $455 \times 5$-m plots (225 $1 \times 1$-m nested subplots) at Fort Necessity National Battlefield, Pennsylvania, U.S.A. Bold-faced species are exotic

Appendix XIVa. List of shrubs and herbs, their exotic/native status, and coefficient of conservatism values (COC) (J. Rentch, West Virginia University, Division of Forestry, unpublished data) from $455 \times 5-\mathrm{m}$ shrub plots and $2251 \times 1-\mathrm{m}$ nested herb plots placed in a degraded meadow dominated by Morrow's honeysuckle at Fort Necessity National Battlefield, Pennsylvania, U.S.A. during the summer of 2004 and 2005. Bold-faced species are exotic.....188

CHAPTER 3. APPENDICES

Appendix Ib. Linear regression models explaining influence of biotic and abiotic environmental variables on patterns of invertebrate abundance under different shrub types $(n=167)$ in a degraded meadow at Fort Necessity National Battlefield, Pennsylvania, U.S.A. Model rankings were based on Akaike's Information Criterion corrected for small sample size $\left(\mathrm{AIC}_{\mathrm{c}}\right)$... 194

Appendix IIb. Linear regression models explaining influence of biotic and abiotic environmental variables on patterns of invertebrate biomass under different shrub types $(n=167)$ in a degraded meadow at Fort Necessity National Battlefield, Pennsylvania, U.S.A. Model rankings were based on Akaike's Information Criterion corrected for small sample size $\left(\mathrm{AIC}_{\mathrm{c}}\right)$.

Appendix IIIb. Abundance, frequency, and total biomass (mg) of 87 invertebrate groups sampled on 45 lone Morrow's honeysuckle shrubs at Fort Necessity National Battlefield, Pennsylvania, U.S.A. during July 2004 and May and August 2005.

Appendix IVb. Abundance, frequency, and total biomass (mg) of 89 invertebrate groups sampled on 45 lone southern arrowwood shrubs at Fort Necessity National Battlefield, Pennsylvania, U.S.A. during July 2004 and May and August 2005. .201

Appendix $\mathrm{Vb}$. Abundance, frequency, and total biomass (mg) of 85 invertebrate groups sampled on 45 dense thickets of Morrow's honeysuckle at Fort Necessity National Battlefield, Pennsylvania, U.S.A. during July 2004 and May and August 2005 .206 
Appendix VIb . $F$ and $p$ values of abundance, biomass, and richness of invertebrates $(\geq 2 \mathrm{~mm}$ in length) sampled in the shrub strata of three shrub types during three different months at Fort Necessity National Battlefield, Pennsylvania, U.S.A.

Appendix VIIb. Mean ( \pm SE) abundance, biomass, and richness of invertebrates $(\geq 2 \mathrm{~mm}$ in length) sampled in the shrub strata based on shrub type and season combinations at Fort Necessity National Battlefield, Pennsylvania, U.S.A.

Appendix VIIIb. Abundance, frequency, and total biomass (mg) of 74 invertebrate groups sampled in the understory of 45 lone Morrow's honeysuckle shrubs at Fort Necessity National Battlefield, Pennsylvania, U.S.A. during July 2004 and May and August 2005.

Appendix IXb. Abundance, frequency, and total biomass (mg) of 71 invertebrate groups sampled in the understory of 45 lone southern arrowwood shrubs at Fort Necessity National Battlefield, Pennsylvania, U.S.A. during July 2004 and May and August 2005.

Appendix Xb. Abundance, frequency, and total biomass (mg) of 67 invertebrate groups sampled in the understory of 45 dense thickets of Morrow's honeysuckle shrubs at Fort Necessity National Battlefield, Pennsylvania, U.S.A. during July 2004 and May and August 2005.

Appendix XIb. Abundance, frequency, and total biomass (mg) of 62 invertebrate groups sampled in the understory of 45 open plots with no overstory at Fort Necessity National Battlefield, Pennsylvania, U.S.A. during July 2004 and May and August 2005. .225

Appendix XIIb. $F$ and $p$ values of abundance, biomass, and richness of invertebrates $(\geq 2 \mathrm{~mm}$ in length) sampled in the understory below four shrub types during three different months at Fort Necessity National Battlefield, Pennsylvania, U.S.A.

Appendix XIIIb. Mean ( \pm SE) abundance, biomass, and richness of invertebrates $(\geq 2 \mathrm{~mm}$ in length) sampled in the understory based on shrub type and season combinations at Fort Necessity National Battlefield, Pennsylvania, U.S.A.

Appendix XIVb. Mean $( \pm \mathrm{SE})$ values of microhabitat variables recorded under Morrow's honeysuckle shrubs (L), southern arrowwood shrubs (V), dense thickets of Morrow's honeysuckle (X), and open plots with no shrub cover $(\mathrm{O})$ at Fort Necessity National Battlefield, Pennsylvania, U.S.A. 231

Appendix XVb. Mean ( $\pm \mathrm{SE}$ ) values of invertebrate abundance, biomass (mg), and microhabitat variables recorded under Morrow's honeysuckle shrubs (L), southern arrowwood shrubs (V), dense thickets of Morrow's honeysuckle (X), and open plots with no shrub cover (O) based on month at Fort Necessity National Battlefield, Pennsylvania, U.S.A.

Appendix XVIb. $F$ and $p$ values of leaf herbivory metrics for Morrow's honeysuckle and southern arrowwood at Fort Necessity National Battlefield, Pennsylvania, U.S.A 
Appendix XVIIb. Mean ( \pm SE) leaf herbivory metrics based on shrub-month combinations at

Fort Necessity National Battlefield, Pennsylvania, U.S.A................................................235 


\section{CHAPTER 1}

INTRODUCTION, LITERATURE REVIEW, AND JUSTIFICATION FOR

RESTORATION OF A DEGRADED MEADOW INFESTED WITH LONICERA

MORROWII (MORROW'S HONEYSUCKLE) AT FORT NECESSITY NATIONAL

BATTLEFIELD, PENNSYLVANIA

Jason P. Love ${ }^{1}$ and James T. Anderson ${ }^{1,2}$

\section{Introduction}

Plant invasions - the spread, proliferation, and persistence of exotic vegetation - threaten biodiversity (Slobodchikoff \& Doyen 1977; Macdonald \& Frame 1988; Jones \& Doren 1997; Manchester \& Bullock 2000), alter ecosystem functions (Vitousek et al. 1987; Gordon 1998; Ehrenfield 2003), and impair both global and local economies (Westbrooks 1998; Naylor 2000; Pimentel et al. 2000; Zavaleta 2000). The threat of invasive exotic plants, animals, and fungi is second only to habitat destruction in causing the endangerment of native species (National Research Council 1995; Wilcove et al. 1998). Over the last few hundred years, the introduction of invasive species by humans has increased exponentially, in concert with the exponential growth of the human population. In more recent decades, global travel and commerce has led to an even greater rise in invasions by exotic species (Mack \& Lonsdale 2001; Mack \& Erneberg 2002).

This chapter written in the style of Restoration Ecology.

\footnotetext{
${ }^{1}$ Division of Forestry and Natural Resources, West Virginia University, Morgantown, WV 26506, U.S.A.

${ }^{2}$ Address correspondence to J. T. Anderson, email wetland@wvu.edu
} 
Today exotic species can be found in nearly every ecosystem that has been monitored (e.g., Cohen \& Carlton 1998).

Exotic Lonicera spp. (bush honeysuckles) are invasive shrubs that are becoming increasingly common throughout eastern and mid-western United States and south-central Canada. Lonicera tatarica (tatarian honeysuckle) was introduced to North America as early as 1752 as an ornamental (Rehder 1940). In the late 1800s, L. maackii (Amur honeysuckle) and $L$. morrowii (Morrow's honeysuckle) were introduced to North America as ornamentals (Rehder 1940; Luken \& Thieret 1995). By the early 1900s, Amur honeysuckle and Morrow’s honeysuckle had escaped cultivation and were widely naturalized in the northeastern United States (Rehder 1903). Subsequent abandonment of agricultural land in the 1920s and 1930s created large areas of suitable habitat for these shrubs (Hauser 1966). Moreover, the shrubs have been planted as shelterbelts in the Midwest (Herman \& Davidson 1997), used in mine reclamation (Wade 1985), and planted for wildlife use (Cook \& Edminster 1944; Edminster 1950; Edminster \& May 1951; Martin et al. 1951; Ripley et al. 1957; Smith 1964; Mulvihill et al. 1992; VanDruff et al. 1996).

Several horticultural varieties of exotic bush honeysuckles have been produced and marketed (Sharp \& Belcher 1981; Dirr 1990; Luken \& Thieret 1996). Like many successful plants used in horticulture, the traits that make exotic honeysuckle shrubs ideal for nurseries and landscaping (i.e., disease free, free of pests, easy to propagate, able to thrive in different environments), also make them successful invaders (Reichard \& White 2001). Even though these shrubs are invasive and negatively affect native species (e.g., Woods 1993; Schmidt \& Whelan 1999; Collier et al. 2002), they are still being purposely propagated and marketed (Dirr 1990; VanDruff et al. 1996; Herman \& Davidson 1997). While ecologists and land managers are 
trying to understand ways to control these species (e.g., Kline 1981; Todd 1985; Nyboer 1992; Hartman \& McCarthy 2004), horticulturalists are engaging in conflicting studies that attempt to increase the shrubs' resilience to pests (Mahr \& Dittl 1986; Herman \& Davidson 1997).

\section{Literature Review}

\section{Description of Exotic Bush Honeysuckles}

Bush honeysuckles are in the Subclass Metachlamydea, Order Rubiales, and Family Caprifoliaceae. This family includes species in the genera Diervilla, Symphoricarpos, Linnaea, Viburnum, and Sambucus. Bush honeysuckles are deciduous shrubs that range in height from 2$6 \mathrm{~m}$. The shrubs have multiple stems and are oppositely-branched. Leaves are opposite, simple, and entire. The showy flowers are paired on axillary peduncles, and the corollas are white, pink, or yellow. The shrubs produce fleshy berries that are red or rarely yellow (Gleason \& Cronquist 1991).

When in flower, exotic bush honeysuckles can be distinguished from native bush honeysuckles by their hirsute styles. Only the native Lonicera oblongifolia (swamp-fly honeysuckle) cannot be distinguished by this characteristic, though other characteristics, such as its hairless leaves and twigs containing solid white pith, can be used to distinguish it from the exotic bush honeysuckles (Petrides 1972). When in fruit, the red or yellow berries of the exotic bush honeysuckles differentiate them from the blue or black berries of the native L. caerulea (waterberry or sweetberry) and L. involucrata (bearberry or twinberry honeysuckle) (Gleason \& Cronquist 1991). Exotic bush honeysuckles typically leaf-out earlier and hold their leaves longer than native bush honeysuckles (Harrington et al. 1989; Trisel \& Gorchov 1994).

Among exotic bush honeysuckles, only Amur honeysuckle has acuminate, lightly pubescent leaves (Luken \& Thieret 1995). Leaves of Amur honeysuckle range in size from 3.5- 
$8.5 \mathrm{~cm}$ (Gleason \& Cronquist 1991). Peduncles are $<6 \mathrm{~mm}$ in length. Branches are hollow with brown pith (Pringle 1973).

Morrow's honeysuckle, tatarian honeysuckle, and the hybrid L. $\times$ bella (Bell's honeysuckle) are difficult to distinguish from one another in the field. Morrow's honeysuckle has elliptic to oblong gray-green leaves that are pubescent beneath. Leaves are 3-6 cm long. Flowers of Morrow's honeysuckle are white, but later fade to yellow. The flowers are pubescent, $1.5-2 \mathrm{~cm}$ long and are attached to densely hairy peduncles 5-15 $\mathrm{mm}$ long. The fruits are red (Fig. 1). The shrub reaches a height of $2 \mathrm{~m}$ (Gleason \& Cronquist 1991). Twigs of Morrow's honeysuckle are hairy and hollow (Petrides 1972).

Tatarian honeysuckle, also called tartarian honeysuckle, has ovate to oblong leaves that are glabrous. Leaves are 3-6 cm long. Flowers of tatarian honeysuckle are glabrous, $1.5-2 \mathrm{~cm}$ long, and the color of the corolla varies from white to pink. The flowers are attached to peduncles 15-25 mm long. Fruits are red or rarely yellow. The plant reaches a height of $3 \mathrm{~m}$ (Gleason \& Cronquist 1991). Twigs are hairless and hollow (Petrides 1972).

Bell's honeysuckle, also known as Bella honeysuckle (Petrides 1972), is a hybrid between Morrow's and tatarian honeysuckle and has intermediate characteristics of its two parent species. Leaves are slightly hairy beneath. Flowers are pink, but fade to yellow over time. The flowers are attached to sparsely hairy peduncles 5-15 mm long. Fruits are red or rarely yellow. Bell's honeysuckle reaches a height of $6 \mathrm{~m}$ (Gleason \& Cronquist 1991). Twigs are hairless, or nearly so, and are hollow (Petrides 1972).

\section{Habitat and Range of Morrow's Honeysuckle}

Morrow's honeysuckle is native to Japan. The shrub was first collected by agriculturist Dr.

James Morrow on a U.S. Naval Expedition to Japan under Commodore M. C. Perry in 1852- 
1854. Specimens were subsequently brought to Cambridge, Massachusetts where the botanist Asa Gray formally described the species and named it after its collector (Barnes \& Cottam 1974). The shrub was introduced to North America in botanical gardens circa 1875 (Rehder 1940). Morrow's honeysuckle has escaped cultivation and is now naturalized in most northeastern and mid-Atlantic states, as well as southeastern and south-central Canada. In North America, the shrub has been reported in the following states and provinces: Arkansas, Colorado, Connecticut, District of Columbia, Illinois, Iowa, Kentucky, Maine, Maryland, North Carolina, Ohio, Ontario, Pennsylvania, Quebec, Rhode Island, Saskatchewan, Tennessee, Vermont, Virginia, West Virginia, Wisconsin, and Wyoming (Batcher \& Stiles 2000).

In North America, Morrow's honeysuckle occupies a wide range of sites. The shrubs are found both on forest edges and in interior forests. They occupy riparian areas and disturbed habitats, including abandoned agricultural land (Hauser 1966), roadsides, and railroad rights-ofway (Barnes \& Cottam 1974). Morrow’s honeysuckle can tolerate a range of soil types, from poorly drained to well drained, and from acidic to calcareous (Barnes \& Cottam 1974; Dirr 1990). In an Ohio forested glen, topography (east vs. west slope) did not play a role in the colonization and establishment of Amur honeysuckle (Gayek \& Quigley 2001). Past anthropogenic land disturbance activities, high levels of land development, and small soil particle size were the top factors influencing invasion of exotic species, including bush honeysuckles, in southern New England (Lundgren et al. 2004). In Ohio, percent cover of Amur honeysuckle and tatarian honeysuckle was best explained by the proportion of urban land cover within $1 \mathrm{~km}$ of riparian forests. Moreover, percent cover of bush honeysuckles was greater in forests within more urban landscapes than in forests within rural landscapes (Borgmann \& Rodewald 2005). 


\section{Reproduction and Dispersal of Exotic Bush Honeysuckles}

Bush honeysuckles reproduce almost entirely by seed, although greenwood and hardwood cuttings have been used extensively in their commercial propagation. Tatarian honeysuckle consistently produces abundant annual seed crops; the seeds ripen June through August (Schopmeyer 1974). Tatarian honeysuckle seeds digested by Turdus migratorius (American Robins) had a higher incidence of germination than control seeds, suggesting that seed scarification may be necessary. However, there was no difference in germination rates when the scarified seeds were compared with seeds that had been cold stratified for 90 days (Krefting \& Roe 1949). Horticultural recommendations for germination of seeds call for a three month stratification at $4.4^{\circ} \mathrm{C}$ (Dirr 1990). In a greenhouse experiment, Luken and Goessling (1995) found that Amur honeysuckle seeds collected in November germinated in just 18 days and continued to germinate three months from planting; light was not necessary for germination. However, another study found both Amur and Morrow's honeysuckle germinated to significantly higher percentages in light than in darkness (Hidayati et al. 2000). About 50\% of the seeds of Amur honeysuckle required warm- or cold stratification only to come out of dormancy; $50 \%$ of Morrow's honeysuckle seeds required warm-stratification only, whereas the other 50\% did not require stratification to germinate. More than $90 \%$ of seeds of Morrow's honeysuckle buried in soil in late June in Kentucky had germinated when they were exhumed in November. Both Amur honeysuckle and Morrow's honeysuckle germinated at high percentages under leaf litter and when buried under soil, suggesting that neither species have the potential to form a persistent seed bank (Hidayati et al. 2000). Deering and Vankat (1999) found that Amur honeysuckle growing in Ohio started producing fruit at 3-8 years of age.

The seeds of exotic bush honeysuckles are dispersed by songbirds (Ingold \& Craycraft 1983; White and Stiles 1992) and Odocoileus virginianus (white-tailed deer) (Vellend 2002). 
Dispersal of seeds by birds contributes to greater germination success by increasing the likelihood that seeds will be dropped in tree fall gaps and other openings rather than in shaded areas (Hoppes 1988). Large expanses of agricultural land act as barriers for dispersal for Amur honeysuckle, while greater forest cover and connectivity facilitate the spread of seeds by birds. In Ohio, Amur honeysuckle moved outward from its point of origin at the rate of $0.1-0.5$ km/year (Hutchinson \& Vankat 1998). Although seeds are consumed by small mammals, rodents are not thought to greatly influence the population dynamics of exotic bush honeysuckles (Williams et al. 1992).

\section{Phenology of Exotic Bush Honeysuckles}

Exotic bush honeysuckles are one of the earliest deciduous plants to leaf out (Harrington et al. 1989; Woods 1993; Trisel \& Gorchov 1994). The shrubs also retain their leaves longer than most other deciduous plants (Woods 1993). Exotic bush honeysuckles thrive in a number of different light regimes (Barnes \& Cottam 1974), though the shrubs grow more vigorously in open conditions (Luken \& Mattimiro 1991; Luken \& Goessling 1995; Luken et al. 1995). The shrubs' long photosynthetic period may explain their competitiveness when growing in shaded areas (Barnes \& Cottam 1974). Amur honeysuckle growing in open areas had significantly higher aboveground net primary production (NPP) and higher aboveground biomass in leaves than forest-grown populations. Open populations also had low stem recruitment and low stem mortality, while Amur honeysuckle growing in the forest had high stem recruitment and high mortality of small stems (Luken 1988). In a woodlot in Ohio, mean biomass of Amur honeysuckle was $361 \pm 69 \mathrm{~kg} / \mathrm{ha}$ and density of plants was $21,380 \pm 3,171$ plants/ha (Hartman \& McCarthy 2004). 


\section{Wildlife Use of Exotic Bush Honeysuckles}

Exotic bush honeysuckles may be important food sources for birds, especially in winter (Ingold \& Craycraft 1983; White \& Stiles 1992). Songbirds in Ohio consumed the fruit of Amur honeysuckle in winter, even though the fruit is bitter and low in fat. The shrubs produce a superabundance of fruits; in a southwestern Ohio study site, there was an estimated crop of over 400 million fruits/ha (Ingold \& Craycraft 1983). Tatarian honeysuckle growing in New Jersey was one of two introduced species used most by frugivores during winter after higher quality native fruit was no longer available (White \& Stiles 1992). Although the fruit of Morrow's honeysuckle is high in sugar $(73.8 \pm 0.7 \%)$, but low in lipids $(<2 \%)$, nitrogen $(0.53 \pm 0.01 \%)$, and protein (2.33\%), captive-fed Bombycilla cedrorum (Cedar Waxwings) fed only honeysuckle fruit maintained a stable body mass over 27 days (Witmer 1996). This is in contrast to fruits such as Viburnum dentatum (southern arrowwood), which are low in sugars (9\%), but relatively high in lipids (45\%) and nitrogen (0.7\%) (Witmer \& Van Soest 1998). Bush honeysuckles were among the highest producers of fruit in suburban forests and shrub-sapling stage forests during fall landbird migration in central Pennsylvania (Rodewald \& Brittingham 2004).

Robinia pseudoacacia (black locust) - tatarian honeysuckle dominated communities were attractive to Colinus virginianus (Northern Bobwhite) and Scolopax minor (American Woodcock) (Ripley et al. 1957). White-tailed deer fed on the leaves and fruit of exotic shrub honeysuckles (Vellend 2002). In southwestern Ohio, Peromyscus maniculatus (deer mice) were the major small mammal consumers of Amur honeysuckle fruit (Williams et al. 1992). It was thought that the spreading branches, coupled with the short pedicels of the berries, may permit easy access to the fruits by small mammals (Williams 1999). In a lab experiment, deer mice readily extracted and consumed seeds from the berries of Amur honeysuckle, although the berries have been described as bitter. They showed no distinct aversion, or preference, towards 
the fruit even when given equal amounts of fruit from other common invasive exotic shrubs and vines (Williams 1999).

Apis mellifera (honey bees) (Hymenoptera: Apidae) are attracted to bush honeysuckles in early summer when the plants are in bloom (Southwick et al. 1981; Clark 1984). Nectar gathered from the flowers creates a light, clear honey with an excellent, delicate flavor (Clark 1984). In Amur honeysuckle, nectar consists primarily of sucrose; one shrub was estimated to contain 21,000 open blossoms, providing $33.6 \mathrm{~g}$ of sugar in $24 \mathrm{hrs}$. (Southwick et al. 1981). In Wisconsin, the spread of exotic bush honeysuckles and other exotic shrubs may cause a restriction in the southern range of Bombus spp. (bumblebees) (Hymenoptera: Apidae) by competing with and subsequently reducing the abundance of native vegetation. Moreover, the abundance of nectar foragers on bush honeysuckles and other exotic shrubs indicates that the exotic plants may be competing with native plants in attracting foraging queens for pollination (Macior 1968). Densities of a predaceous mite (Kampimodromous aberrans; Acari:

Phytoseiidae) in vineyards were compared among several shrub species with different leaf characteristics, including bush honeysuckles, in France and Italy (Kreiter et al. 2002). A new mirine plant bug (Polymeria lonicerae; Heteroptera: Miridae) was collected from the Russian Far East on its host plant, Amur honeysuckle (Yasunaga 1997). However, most invertebrate studies have focused on Hyadaphis tataricae (honeysuckle aphid) (Homoptera: Aphididae), one of the few pests of bush honeysuckles (Mahr \& Dittl 1986; Herman \& Davidson 1997).

\section{Ecological Impacts of Exotic Bush Honeysuckles}

Although most studies have focused on the impacts of Amur honeysuckle, nearly all exotic bush honeysuckles, including Morrow's honeysuckle, can negatively impact forest regeneration and native herb diversity (Batcher \& Stiles 2000). In mesic forests of Vermont and Massachusetts, 
herb species richness, percent herbaceous cover, and density of tree seedlings were significantly depressed when tatarian honeysuckle cover exceeded 30\% (Woods 1993). In southwestern Ohio, tree seedling density, species richness of seedlings, and herb cover were all inversely related to Amur honeysuckle cover (Hutchinson \& Vankat 1997). Amur honeysuckle lowered plant species richness and abundance in secondary forests in Ohio (Collier et al. 2002). The presence of Amur honeysuckle lowered the fitness (the product of survival and fecundity) of three annuals growing in a forest in Ohio (Gould \& Gorchov 2000). In a field experiment in Ohio, Amur honeysuckle did not affect survival of three transplanted native herb species, but did reduce growth, final size, and seed production (Miller \& Gorchov 2004). Removal of Amur honeysuckle in Kentucky forests increased the density of generalist species that occur in early successional habitats (Luken et al. 1997). Within a single woodlot in Ohio, Amur honeysuckle basal area negatively affected species richness, basal area of native shrubs, and sapling density of native trees (Medley 1997). Although the shoots of Amur honeysuckle conferred some protection from deer browsing of native seedlings, the overall effect of the shrub was increased mortality of native tree seedlings (Gorchov \& Trisel 2003; Hartman \& McCarthy 2004). In Wisconsin forests, Cornus racemosa (gray dogwood) was negatively associated with Bell's honeysuckle (Barnes 1972). The shrubs degraded early successional (Fort Necessity National Battlefield 1991) and prairie habitat (McClain \& Anderson 1990; Laughlin 2004) and are becoming common invaders of natural areas (Crandall \& Dolan 1997).

Most studies agree that the shrub honeysuckle negatively impacts herbaceous diversity and seedling recruitment by shading (e.g., Barnes \& Cottam 1974; Gorchov \& Trisel 2003). However, there also is evidence that Amur honeysuckle may be allelopathic (Barnes 1972; Trisel 1997), a trait shared with other species in the genus Lonicera (Skulman et al. 2004). Trisel and 
Gorchov (1994) examined herbarium specimens of Amur honeysuckle and found less leaf damage compared to native shrubs, suggesting that the shrub may be relatively free from herbivores and/or pathogens; the lack of herbivores and pathogens may be partly responsible for its success in invading foreign soils (i.e., enemy release hypothesis - see Schierenbeck et al. 1994; Williamson 1996; Maron \& Vilà 2001; Siemann \& Rogers 2003).

Although the shrubs provide nesting substrate for many bird species (Whelan \& Dilger 1992), some bird species may have increased nest predation in shrub honeysuckles versus native shrubs. In Illinois, nest predation was higher in American Robin nests found in Amur honeysuckle; lower nest height, the absence of thorns, and branch architecture may have made it easier for predators to access American Robin nests in Amur honeysuckle compared to nests found in native shrubs (Schmidt \& Whelan 1999). In Ohio, Cardinalis cardinalis (Northern Cardinals) and American Robins had significantly higher nest predation in exotic honeysuckle shrubs compared to nests located in native shrubs. Nests in exotic shrubs located in urban landscapes were particularly vulnerable to predation compared to nests in more rural environments. Nests in exotic shrubs were 1.5-2 $\mathrm{m}$ lower to the ground and within patches containing 6-9 times more exotic shrub volume. Artificial nests placed in both native and exotic honeysuckle shrubs confirmed that nest predation was higher in exotic shrubs; based on marks recovered from the clay eggs, $68 \%$ of artificial nest predation was from mammals, while avian predators accounted for $19 \%$ of depredated eggs (Borgmann \& Rodewald 2004).

Cedar Waxwings feeding on the fruit of Morrow's honeysuckle and tatarian honeysuckle in New York were found to have orange tail bands instead of the normal yellow tail bands. Biochemical studies revealed that red carotenoid pigments (rhodoxanthin) found in the fruits of bush honeysuckles were responsible for the novel tail band coloration (Witmer 1996). If tail 
coloration is important in mate selection, then orange tail coloration may affect the attractiveness of Cedar Waxwings as mates (see Burley et al. 1982).

In an Ohio old-growth forest, diversity of amphibians and some reptiles was reduced in areas dominated by Amur honeysuckle. Plethodon glutinosus (northern slimy salamanders) and Rana clamitans (green frogs) had significantly reduced body mass in areas dominated by the honeysuckle compared to areas free of the shrub, suggesting that prey items (i.e., grounddwelling invertebrates) might be reduced under Amur honeysuckle. Terrapene carolina (eastern box turtles) were found only in the non-invaded areas, while snakes were found solely in habitats invaded by Amur honeysuckle. These findings suggest that the ecological changes caused by Amur honeysuckle may reduce the quality of habitat for some herpetofauna, while increasing habitat quality for other species (McEvoy \& Durtsche 2004).

There is growing evidence that invasive exotic plants may reduce insect abundance and diversity, particularly phytophagous insects (Olckers \& Hulley 1991; Samways et al. 1996; Fenner \& Lee 2001; Tewksbury et al. 2002). Phytophagous insects make up an estimated 26\% of animal species (Weis \& Berenbaum 1988) and play a critical role in transferring energy from plants to higher trophic levels (Wilson 1987). At least 90\% of phytophagous insects are specialists, feeding on specific plant hosts (Bernays \& Graham 1988). Although no studies have been performed that explicitly examine insect biomass of exotic plants versus closely-related native plants, it is possible that invasive exotic plants such as Morrow's honeysuckle reduce insect biomass, which in turn would negatively affect organisms of higher trophic levels (Tallamy 2004). By decreasing herbaceous diversity (e.g., Collier et al. 2002), exotic bush honeysuckles also may indirectly influence the abundance, diversity, and biomass of grounddwelling arthropods. For example, diversity of spiders (Arachnida: Araneae) in hedgerows 
dominated by Amur honeysuckle in Ohio was low relative to other vegetative communities. Amur honeysuckle caused reduced complexity in the ground layer, thus reducing grounddwelling spider diversity (Buddle et al. 2004).

\section{Pests and Diseases of Exotic Bush Honeysuckles}

Studies on invertebrate use of bush honeysuckles have focused on the honeysuckle aphid. The honeysuckle aphid is from the same region of Russia as its host plant, tatarian honeysuckle (Mahr \& Dittl 1986; Herman \& Davidson 1997). In North America the insect was first discovered in Quebec in the mid-1970s on infested plants from Europe (Boisvert et al. 1981). It is now found throughout North America. This insect infests the terminals of tatarian honeysuckle and related species. Feeding results in severely deformed terminals, commonly called "witches brooms" (Mahr \& Dittl 1986, Herman \& Davidson 1997). Infestations reduce fruit production and may cause mortality in the plant. Injury to the honeysuckle is the result of the plants' response to toxins or growth regulating substances in the aphids' saliva (Johnson \& Lyon 1988). Native lady bug beetles (Coleoptera: Coccinellidae) have been noted to control the honeysuckle aphid (Nyboer 1992).

White-tailed deer also may impact bush honeysuckles. In a Virginia pasture, tatarian honeysuckle was significantly higher in areas excluded from deer, suggesting that deer browsing may decrease bush honeysuckles in some circumstances (Bowers 1997; but see Vellend 2002).

Several species of bush honeysuckles are susceptible to leaf blight caused by the fungus Insolibasidium deformans (Auriculariales: Auriculariaceae). Symptoms include a slight crinkling or rolling of infected areas before the leaves turn yellow then brown after several days. Epidemics may cause defoliation, dieback, and reduced growth. The fungus can be found in the Midwest, eastern U.S., Pacific Northwest, and Canada (Sinclair et al. 1987). The blight has 
infected Morrow's honeysuckle at Fort Necessity National Battlefield (J. Love 2004, personal observation; confirmed by W. MacDonald 2004, Division of Plant \& Soil Sciences, West Virginia University, Morgantown).

\section{Control and Management of Exotic Bush Honeysuckles}

Exotic shrub honeysuckles have become a top priority for control efforts (e.g., Fort Necessity National Battlefield 1991; Tennessee Exotic Pest Plant Council 1996). Even though several methods of controlling shrub honeysuckles have been described (Kline 1981; Todd 1985; Luken 1990; Nyboer 1992; Batcher \& Stiles 2000), few rigorous studies exist that compare different management strategies (Luken \& Mattimiro 1991; Hartman \& McCarthy 2004). A need exists for more efficient control measures (Batcher and Stiles 2000).

Todd (1985) found that hand-pulling small shrubs after rain were successful in controlling bush honeysuckles. Larger shrubs were cut and pulled the following year. There was no regrowth on the 0.1 ha plot where this study was carried out. Hand-pulling small shrubs was found to be effective, but labor intensive (Batcher \& Stiles 2000). All of the large roots must be pulled out or resprouting will occur (Nyboer 1992; Gayek 2000). Pulling out larger shrubs with a tractor and chain was effective in eliminating Morrow's honeysuckle in a degraded wet meadow, but this approach was labor intensive (C. Ranson 2004, Fort Necessity National Battlefield, Farmington, PA, personal communication).

Clipping or cutting shrubs is unsuccessful unless carried-out repeatedly (Luken 1990; Luken \& Mattimiro 1991; Nyboer 1992). Clipping is more successful if the plants are growing under shade (Luken 1990; Luken \& Mattimiro 1991). Winter clipping encourages vigorous resprouting the following spring (Batcher \& Stiles 2000). The wood of bush honeysuckles is tough and dulls power-tool blades (Nyboer 1992). 
Herbicides are commonly used to control bush honeysuckles (Batcher \& Stiles 2000). Foliar applications of glyphosate or triclopyr ( $2 \%$ solutions) have been used with varying degrees of success (Nyboer 1992). In an Ohio nature preserve, a 1\% foliar application of glyphosate was effective in controlling Amur honeysuckle. Both spring and fall treatments were effective, though fall treatments had less impact on native shrubs and tree seedlings since most native plants were dormant at the time of treatment (Conover \& Geiger 1993). For foliar applications of herbicide, Miller (2003) suggested using a 2\% solution of glyphosate mixed with a surfactant; this treatment should be applied from August to October for best results. Bush honeysuckles treated in summer with a $2 \%$ foliar application of glyphosate had mortality rates of $80-95 \%$ after 100 days. The success of the treatment varies with season and the physiological stage of growth, with treatment success in autumn $>$ summer $>$ spring. Autumn is the best time to apply glyphosate because the mature senescing leaves translocate the herbicide rapidly to root systems, whereas in spring there may be insufficient tissue to afford significant translocation to roots. Other factors that may negatively affect translocation of glyphosate include drought stress, temperature extremes, insect damage, and disease stress (Lynn et al. 1979).

Most land managers use glyphosate ( $20 \%$ solution) as a cut-stump treatment to control bush honeysuckles (Batcher \& Stiles 2000; Miller 2003). Miller (2003) suggested applying one of the following herbicides with a surfactant to freshly cut stumps of bush honeysuckles: $10 \%$ solution of Arsenal AC (BASF Corporation, Research Triangle Park, NC, U.S.A.) or a $20 \%$ solution of glyphosate. Kline (1981) compared 20 and 50\% solutions of Roundup (Monsanto Company, St. Louis, MO, U.S.A.) applied to cut-stumps and found both methods were successful in controlling Bell's honeysuckle growing in Wisconsin. Application of herbicides to freshly cut Bell's honeysuckle stumps did not kill neighboring native plants (Kline et al. 1982). 
In Ohio, glyphosate killed $\geq 94 \%$ of Amur honeysuckle stems using either a cut-stump treatment with a solution of 50\% glyphosate or stem injection with an EZ-Ject lance (Odum Processing Engineering Consulting, Inc.; Waynesboro, MO, U.S.A.) (Hartman \& McCarthy 2004). Glyphosate capsules injected into Amur honeysuckle stems $>2.5 \mathrm{~cm}$ in diameter killed $78 \%$ of the shrubs (Franz \& Keiffer 2000). The cut-stump treatment works best in late summer, early fall, or in the dormant season (Nyboer 1992). A 20\% solution of Garlon 4 (Dow AgroSciences LLC, Indianapolis, IN, U.S.A.) in commercially available basal oil, diesel fuel, or kerosene mixed with a penetrant controls bush honeysuckles when sprayed on young bark as a basal spray (Miller 2003).

Prescribed burning during the growing season top-kills shrubs and inhibits new shoot production. Because exotic bush honeysuckles resprout, repeated burnings (every year or every other year) may be necessary (Nyboer 1992). Fire may play an important role in maintaining prairie communities by killing exotic woody invaders like bush honeysuckles (Laughlin 2004).

\section{Justification for Study}

\section{Introduction}

Exotic bush honeysuckles are becoming increasingly common invaders in eastern North America and southern portions of Canada (Batcher \& Stiles 2000). The plants are aggressive colonizers in secondary forests and early successional habitats (Barnes \& Cottam 1974; Luken \& Goessling 1995). Exotic shrub honeysuckles decrease species richness and inhibit forest regeneration in forested habitats (Woods 1993; Collier et al. 2002; Gorchov \& Trisel 2003; Hartman \& McCarthy 2004). However, there are no studies that examine the effect of exotic shrub honeysuckle removal on herbaceous species growing in a degraded meadow. Descriptive evaluations of shrub honeysuckle removal methods have been performed (e.g., Kline 1981; Todd 
1985; Nyboer 1992), but few quantitative studies exist (Luken \& Mattimiro 1991; Hartman \& McCarthy 2004). Because shrub honeysuckles are becoming increasingly common invaders in a number of different habitats, there is a strong need for more efficient control efforts (Batcher \& Stiles 2000).

At Fort Necessity National Battlefield in southern Pennsylvania, Morrow's honeysuckle has successfully invaded both meadows and forests (Fort Necessity National Battlefield 1991). The General Management Plan for Fort Necessity states that "the forest will be managed to prevent damage by exotic species" and "the park will manage species to help maintain health and diversity within the ecosystem, to ensure the continuation of rare, threatened, or endangered species, and to work toward reestablishing the vegetative conditions that existed during the historical period whenever possible" (Fort Necessity National Battlefield 1991). Morrow's honeysuckle infestation has impeded efforts to restore a degraded meadow to a desired historical and ecological condition (C. Ranson 2004, Fort Necessity National Battlefield, Farmington, Pennsylvania, personal communication). Moreover, Morrow's honeysuckle may be the cause of recent declines in two native plant species of special concern at Fort Necessity National Battlefield, Houstonia purpurea var. purpurea (purple bluet) and Hypericum densiflorum (bushy St. Johnswort) (Western Pennsylvania Conservancy 2003). Exotic bush honeysuckles also may negatively influence invertebrate abundance, diversity (Buddle et al. 2004), and biomass, which could negatively effect organisms at higher trophic levels (Tallamy 2004).

\section{Site Description}

Fort Necessity National Battlefield is a 350.5 ha historical park located in Fayette County in southwestern Pennsylvania (394 $48^{\prime} 43^{\prime \prime}$ N, $84^{\circ} 41^{\prime} 50^{\prime}$ W) (Fig. 2). The park lies in the Allegheny Mountains of the Appalachian Plateau, an area also known as the southern Laurel 
Highlands. The battlefield straddles an upland valley between Chestnut Ridge and Laurel Hill. Land within the park is rolling and well-drained, with the exception of the Great Meadows, a wet meadow complex in the northern corner the park. Elevations within the park range from $535-$ 710 m (Fort Necessity National Battlefield 1991).

Low lying areas within the meadow are characterized by Philo silt loams. These soils are deep, poor to moderately drained, medium textured, and were formed from acidic sediments derived from sandstone and shale. Upland sites within the meadow consist of Brinkerton and Armagh silt loams, Cavode silt loams, and Gilpin channery silt loams. These soils are moderately deep, moderate to well drained, medium-textured, and underlain by acidic shale and sandstone bedrock (Kopas 1973).

The climate is moderate continental. The average annual temperature is $9^{\circ} \mathrm{C}$. Mean winter temperature is $-3^{\circ} \mathrm{C}$ and mean summer temperature is $22^{\circ} \mathrm{C}$. Average annual precipitation is $119 \mathrm{~cm}$ (Fort Necessity National Battlefield 1991).

The study site is located on a hillside west of the replication of Fort Necessity (Fig. 3), a hastily-built fort constructed by George Washington and his troops in 1754 at the onset of the French-Indian War. The hillside was formerly an oak-hardwood forest, but was cleared for pasture prior to the establishment of the park in 1933 (Fort Necessity National Battlefield 1991). Pollen samples taken from cores near the fort reveal that Quercus spp. (oaks), Carya spp. (hickories), Betula spp. (birch), Fagus grandifolia (American beech), and Acer rubrum (red maple) were the major components of the forest prior to clearing (Kelso 1994). The pasture was maintained by mowing until the mid-1980s, at which time mowing ceased. It was thought that passive management would allow natural succession to occur, permitting the meadow to be eventually reforested by native hardwoods (C. Ranson 2004, Fort Necessity National Battlefield, 
Farmington, PA, personal communication). However, reforestation never occurred and today the pasture is characterized by a dense cover of Morrow's honeysuckle and other exotic species (Fort Necessity National Battlefield 1991) (Figs. 4 \& 5).

\section{Objectives and Hypotheses}

Relating total non-structural carbohydrates to plant phenological stages

Relating total nonstructural carbohydrate (TNC) levels to plant phenological stages allows resource managers to know when the best time is to mechanically remove or apply herbicide to undesirable plant species (Sosebee 1983). I hypothesized that mechanical removal methods should be most successful in the spring immediately after leaf formation. During this period plants have low levels of TNC and have difficulty resprouting. Herbicide application should be best in the fall, when TNC levels are highest. The shrubs are actively translocating carbohydrates to the roots for storage during this period; any herbicides applied during this time would also be transported down to the roots, making the plant more susceptible to the effects of the herbicide.

Roots of Morrow's honeysuckle were collected once a month for one year from March 2004 to February 2005. Prior to collection, the phenological stage (dormant, bud break, leaf development, seed formation, seed maturation, or leaf abscission) of the plant were noted (Sosebee 1983; Conway et al. 1999). The roots were analyzed for TNC using the anthrone reagent procedure (Yemm \& Willis 1954).

\section{Assessing removal methods of Morrow's honeysuckle}

The objectives of this portion of the study were to evaluate the success of four different control methods on Morrow's honeysuckle. I predicted that cut-stump herbicide treatment in late 
summer/early fall would be the most successful method, since the upper portion of the plant will be physically removed and the herbicide will be applied immediately afterwards when the phloem is in the process of translocating carbohydrates to the roots for storage. I compared a foliar application of $2 \%$ glyphosate (Roundup Pro; Monsanto, St. Louis, MO, U.S.A.), a cutstump application of $20 \%$ glyphosate, mechanical removal of the shrubs using a pulaski, and cutting the base of the shrubs with a chainsaw. I also compared the impacts of the different removal methods on the percent cover and composition of herbaceous species. Differences between early summer and late summer applications of the removal methods were also analyzed. Moreover, costs and time (person-hrs) for each method were evaluated.

Comparing abundance, biomass, and richness of invertebrates found on Morrow's honeysuckle to invertebrates found on a native shrub

The enemy release hypothesis predicts that 1) successful plant invaders have left behind herbivores and pathogens found in their native habitat and 2) herbivores and pathogens in the new habitat are lacking (e.g., Elton 1958). If this is true, then exotic plants should have a lower abundance of invertebrates than those found on native plants. Previous studies also have shown that the herbaceous layer is less diverse under bush honeysuckles compared to areas without honeysuckle (e.g., Woods 1993, Collier et al. 2002). If herbaceous diversity is negatively affected under canopies of bush honeysuckle, then arthropod abundance, diversity, and biomass should also be depressed (e.g., Buddle et al. 2004).

The invasive exotic Morrow's honeysuckle and a common native shrub, Viburnum recognitum (southern arrowwood) were the two most abundant shrubs in a degraded meadow at Fort Necessity National Battlefield (Chapter 2). Both shrubs are in the family Caprifoliaceae. 
Using a modified leaf blower-vacuum, we sampled invertebrates in the shrub layer and understory. We tested whether arthropod abundance, biomass, and diversity were significantly different among 1) the shrub layer of Morrow's honeysuckle occurring singly, dense thickets of

Morrow's honeysuckle, and single shrubs of southern arrowwood, and 2) among understory plots located below single Morrow's honeysuckle shrubs, dense thickets of Morrow's honeysuckle, single southern arrowwood shrubs, and open plots without shrub cover. The results of this study should give new insights to the effects of invasive plants on invertebrate communities, while also providing a baseline from which future restoration efforts can be measured.

\section{LITERATURE CITED}

Barnes, W. J. 1972. The autoecology of the Lonicera $\times$ bella complex. Ph.D. Dissertation. University of Wisconsin, Madison.

Barnes, W. J., and G. Cottam. 1974. Some autoecological studies of the Lonicera $\times$ bella complex. Ecology 55:40-50.

Batcher, M. S., and S. A. Stiles. 2000. Element stewardship abstract for Lonicera maackii (Rupr.) Maxim (Amur honeysuckle), Lonicera morrowii A. Gray (Morrow's honeysuckle), Lonicera tatarica L. (Tatarian honeysuckle), Lonicera $\times$ bella Zabel (Bell's honeysuckle). The Nature Conservancy, Arlington, Virginia. Available from http://tncweeds.ucdavis.edu/esadocs/documnts/loni_sp.pdf (accessed October 2005).

Bernays, E., and M. Graham. 1988. On the evolution of host specificity in phytophagus arthropods. Ecology 69:886-892.

Boisvert, J., C. Cloutier, and J. McNeil. 1981. Hyadaphis tataricae (Homoptera: Aphididae), a pest of the honeysuckle new to North America. Canadian Entomologist 113:415-418. 
Borgmann, K. L., and A. D. Rodewald. 2004. Nest predation in an urbanizing landscape: the role of exotic shrubs. Ecological Applications 14:1757-1765.

Borgmann, K. L., and A. D. Rodewald. 2005. Forest restoration in urbanizing landscapes: interactions between land uses and exotic shrubs. Restoration Ecology 13:334-340.

Bowers, M. A. 1997. Influence of deer and other factors on an old-field plant community. Pages 310-326 in W. J. McShea, H. B. Underwood, and J. H. Rappole, editors. The science of overabundance: deer ecology and population management. Smithsonian Books, Washington D.C.

Buddle, C. M., S. Higgins, and A. L. Rypstra. 2004. Ground-dwelling spider assemblages inhabiting riparian forests and hedgerows in an agricultural landscape. American Midland Naturalist 151:15-26.

Burley, N., G. Krantzberg, and P. Radman. 1982. Influence of colour-banding on the conspecific preferences of Zebra Finches. Animal Behaviour 30:444-455.

Clark, R. C. 1984. Amur honeysuckle: a significant but weedy early season nectar producer. American Bee Journal 125:857.

Cohen, A. N., and J. T. Carlton. 1998. Accelerating invasion rate in a highly invaded estuary. Science 279:555-558.

Collier, M. H., J. L. Vankat, and M. R. Hughes. 2002. Diminished plant richness and abundance below Lonicera maackii, an invasive shrub. American Midland Naturalist 147:60-71.

Conover, D. G., and D. R. Geiger. 1993. Glyphosate controls Amur honeysuckle in native woodland restoration (Ohio). Restoration and Management Notes 11:168-169.

Conway, W. C., L. M. Smith, R. E. Sosebee, and J. F. Bergan. 1999. Total nonstructural carbohydrate trends in Chinese tallow roots. Journal of Range Management 52:539-542. 
Cook, D. B., and F. C. Edminster. 1944. Survival and growth of shrubs planted for wildlife in New York. Journal of Wildlife Management 8:185-191.

Crandall, R. M. and R. W. Dolan. 1997. Floristic investigation of Crooked Creek Community Juan Solomon Park, Indianapolis, Indiana. Proceedings of the Indiana Academy of Science 106:1-23.

Deering, R. H., and J. L. Vankat. 1999. Forest colonization and developmental growth of the invasive shrub Lonicera maackii. American Midland Naturalist 141:43-50.

Dirr, M. A. 1990. Manual of woody landscape plants: their identification, ornamental characteristics, culture, propagation, and uses. 4th edition. Stipes Publishing Company, Champaign, Illinois.

Edminster, F. C. 1950. Use of shrubs in developing farm wildlife habitat. Transactions of the North American Wildlife Conference 15:519-550.

Edminster, F. C., and R. M. May. 1951. Shrub plantings for soil conservation and wildlife cover in the Northeast. U.S. Department of Agriculture Circular No. 887, Washington D.C.

Ehrenfield, J. G. 2003. Effects of exotic plant invasions on soil nutrient cycling processes. Ecosystems 6:503-523.

Elton, C. S. 1958. The ecology of invasion by plants and animals. Chapman and Hall, London, United Kingdom.

Fenner, M., and W. G. Lee. 2001. Lack of pre-dispersal seed predators in introduced Asteraceae in New Zealand. New Zealand Journal of Ecology 25:95-99.

Fort Necessity National Battlefield. 1991. General Management Plan/Development Concept Plan/Interpretive Prospectus. Unpublished report. 
Franz, C. R., and C. Keiffer. 2000. Effectiveness of the EZJect capsule injection system against the invasive shrub, Amur honeysuckle. The Ohio Woodland Journal 7:19-20.

Gayek, A. 2000. Effect of habitat variation on rate and success of colonization of two invasive shrubs, Lonicera maackii and Ligustrum vulgare, in a forested glen. MS Thesis. Ohio State University, Columbus.

Gayek, A., and M. F. Quigley. 2001. Does topography affect the colonization of Lonicera maackii and Ligustrum vulgare in a forested glen in southwestern Ohio? Ohio Journal of Science 101:95-100.

Gleason, H. A., and A Cronquist. 1991. Manual of vascular plants of northeastern United States and adjacent Canada. 2nd edition. The New York Botanical Garden, Bronx.

Gorchov, D. L., and D. E. Trisel. 2003. Competitive effects of the invasive shrub, Lonicera maackii (Rupr.) Herder (Caprifoliaceae), on the growth and survival of native tree seedlings. Plant Ecology 166:13-24.

Gordon, D. R. 1998. Effects of invasive, non-indigenous plant species on ecosystem processes: lessons from Florida. Ecological Applications 8:975-989.

Gould, A. M. A., and D. L. Gorchov. 2000. Effects of the exotic invasive shrub Lonicera maackii on the survival and fecundity of three species of native annuals. American Midland Naturalist 144:36-50.

Harrington, R. A., B. J. Brown, and P. B. Reich. 1989. Ecophysiology of exotic and native shrubs in southern Wisconsin: relationship of leaf characteristics, resource availability, and phenology to seasonal patterns of carbon gain. Oecologia 80:356-367. 
Hartman, K. M., and B. C. McCarthy. 2004. Restoration of a forest understory after the removal of an invasive shrub, Amur honeysuckle (Lonicera maackii). Restoration Ecology 12:154-165.

Hauser, E. J. P. 1966. The natural occurrence of a hybrid honeysuckle $($ Lonicera $\times$ bella $)$ in Ohio and Michigan. Michigan Botanist 5:211-217.

Herman, D. E., and C. G. Davidson. 1997. Evaluation of Lonicera taxa for honeysuckle aphid susceptibility, winter hardiness and use. Journal of Environmental Horticulture 15:177182.

Hidayati, S. N., J. M. Baskin, and C. C. Baskin. 2000. Dormancy-breaking and germination requirements of seeds of four Lonicera species (Caprifoliaceae) with underdeveloped spatulate embryos. Seed Science Research 10:459-469.

Hoppes, W. G. 1988. Seedfall pattern of several species of bird-dispersed plants in an Illinois woodland. Ecology 69:320-329.

Hutchinson, T. F., and J. L. Vankat. 1997. Invasibility and effects of Amur honeysuckle in southwestern Ohio forests. Conservation Biology 11:1117-1124.

Hutchinson, T. F., and J. L. Vankat. 1998. Landscape structure and spread of the exotic shrub Lonicera maackii (Amur honeysuckle) in southwestern Ohio forests. American Midland Naturalist 139:383-390.

Ingold, J. L., and M. J. Craycraft. 1983. Avian frugivory on honeysuckle (Lonicera) in southwestern Ohio in the fall. Ohio Journal of Science 83:256-258.

Johnson, W. T., and H. H. Lyon. 1988. Insects that feed on trees and shrubs. Comstock Publishing Associates, Cornell University Press, Ithaca, New York. 
Jones, D. T., and R. F. Doren. 1997. The distribution, biology and control of Schinus terebinthifolius in southern Florida, with special reference to Everglades National Park. Pages 81-93 in J. H. Brock, M. Wade, P. Pysek, and D. Green, editors. Plant invasions: studies from North America and Europe. Backhuys Publishers, Leiden, The Netherlands.

Kelso, G. K. 1994. Palynology in historical rural landscape studies: the pre-clearance forest border at Great Meadows, Pennsylvania. National Park Service, Technical Report NPS/MARFONE/NRTR - 95/067.

Kline, V. 1981. Control of honeysuckle and buckthorn in oak forests. Restoration and Management Notes 1:18.

Kline, V. M., G. Cottam, and T. Samingan. 1982. Response of oak woods understory plants to eradication of dense growth of an exotic invader, Lonicera $\mathrm{x}$ bella. Bulletin of the Ecological Society of America 63:102.

Kopas, F. A. 1973. Soil survey of Fayette County, Pennsylvania. U.S. Department of Agriculture, Soil Conservation Service, U.S. Government Printing Office, Washington D.C.

Krefting, L. W., and E. I. Roe. 1949. The role of some birds and mammals in seed germination. Ecological Monographs 19:269-286.

Kreiter, S., M.-S. Tixier, B. A. Croft, P. Auger, and D. Barret. 2002. Plants and leaf characteristics influencing the predaceous mite Kampimodromous aberrans (Acari: Phytoseiidae) in habitats surrounding vineyards. Environmental Entomology 31:648-660.

Laughlin, D. C. 2004. Woody plant invasion and the importance of anthropogenic disturbance within xeric limestone prairies. Journal of the Pennsylvania Academy of Science 78:1228. 
Luken, J. O. 1988. Population structure and biomass allocation of the naturalized shrub Lonicera maackii (Rupr.) Maxim. in forest and open habitats. American Midland Naturalist 119:258-267.

Luken, J. O. 1990. Forest and pasture communities respond differently to cutting of exotic Amur honeysuckle. Restoration and Management Notes 8:122-123.

Luken, J. O., and D. T. Mattimiro. 1991. Habitat-specific resilience of the invasive shrub Amur honeysuckle (Lonicera maackii) during repeated clipping. Ecological Applications 1:104109.

Luken, J. O., and N. Goessling. 1995. Seedling distribution and potential persistence of the exotic shrub Lonicera maackii in fragmented forests. American Midland Naturalist 133:124-130.

Luken, J. O., and J. W. Thieret. 1995. Amur honeysuckle (Lonicera maackii, Caprifoliaceae): its ascent, decline, and fall. Sida 16:479-503.

Luken, J. O., T. C. Tholemeir, L. M. Kuddes, and B. A. Kunkel. 1995. Performance, plasticity, and acclimation of the nonindigenous shrub Lonicera maackii (Caprifoliaceae) in contrasting light environments. Canadian Journal of Botany 73:1953-1961.

Luken, J. O., and J. W. Thieret. 1996. Amur honeysuckle, its fall from grace. BioScience 46:1824.

Luken, J. O., L. M. Kuddes, and T. C. Tholemeier. 1997. Response of understory species to gap formation and soil disturbance in Lonicera maackii thickets. Restoration Ecology 5:229235. 
Lundgren, M. R., C. J. Small, and G. D. Dreyer. 2004. Influence of land use and site characteristics on invasive plant abundance in the Quinebaug Highlands of southern New England. Northeastern Naturalist 11:313-332.

Lynn, L. B., R. A. Rogers, and J. C. Graham. 1979. Response of woody species to glyphosate in northeastern states. Proceedings of the Northeastern Weed Science Society 33:336-342.

Macdonald, I. A. W., and G. W. Frame. 1988. The invasion of introduced species into nature reserves in tropical savannahs and dry woodlands. Biological Conservation 44:67-93.

Macior, L. W. 1968. Bombus (Hymenoptera, Apidae) queen foraging in relation to vernal pollination in Wisconsin. Ecology 49:20-25.

Mack, R. N., and W. M. Lonsdale. 2001. Humans as global plant dispersers: getting more than we bargained for. BioScience 51:95-102.

Mack, R. N., and M. Erneberg. 2002. The United States naturalized flora: largely the product of deliberate introductions. Annals of the Missouri Botanical Gardens 89:176-189.

Mahr, D. L., and T. G. Dittl. 1986. Chemical, natural, and cultural control of Hyadaphis tataricae (Homoptera: Aphididae) on honeysuckle. The Great Lakes Entomologist 19:91100.

Manchester, S. J., and J. M. Bullock. 2000. The impacts of non-native species on UK biodiversity and the effectiveness of control. Journal of Applied Ecology 37:845-864.

Maron, J. L., and M. Vilà. 2001. When do herbivores affect plant invasion? Evidence for the natural enemies and biotic resistance hypothesis. Oikos 95:361-373.

Martin, A. C., H. S. Zim, and A. L. Nelson. 1951. American wildlife and plants: a guide to wildlife food habits. Dover Publications, Inc., New York, New York. 
McClain, W. E., and E. A. Anderson. 1990. Loss of hill prairie through woody plant invasion at Pere Marquette State Park, Jersey County, Illinois. Natural Areas Journal 10:69-75.

McEvoy, N. L., and R. D. Durtsche. 2004. Effect of the invasive shrub Lonicera maackii (Caprifoliaceae; Amur honeysuckle) on autumn herptofauna biodiversity. Journal of the Kentucky Academy of Science 65:27-32.

Medley, K. E. 1997. Distribution of the non-native shrub Lonicera maackii in Kramer Woods, Ohio. Physical Geography 18:18-36.

Miller, J. H. 2003. Nonnative invasive plants of southern forests: a field guide for identification and control. Revised. General Technical Report SRS-62. United States Department of Agriculture, Forest Service, Southern Research Station, Asheville, North Carolina.

Miller, K. E., and D. L. Gorchov. 2004. The invasive shrub, Lonicera maackii, reduces growth and fecundity of perennial forest herbs. Oecologia 139:359-375.

Mulvihill, R. S., K. C. Parker, R. C. Leberman, and D. S. Wood. 1992. Evidence for supporting a dietary basis for orange-tipped retrices in the Cedar Waxwing. Journal of Field Ornithology 63:212-216.

National Research Council. 1995. Science and the Endangered Species Act. National Academy, Washington D.C.

Naylor, R. L. 2000. The economics of alien species invasions. Pages 241-259 in H. A. Mooney and R. J. Hobbs, editors. Invasive species in a changing world. Island Press, Washington D.C.

Nyboer, R. 1992. Vegetation management guideline: bush honeysuckles - tatarian, Morrow's, Belle, and Amur honeysuckle (Lonicera tatarica L., L. morrowii Gray, L. x bella Zabel, and L. maackii [Rupr.] Maxim.). Natural Areas Journal 12:218-219. 
Olckers, T., and P. E. Hulley. 1991. Impoverished insect herbivore faunas on the exotic bugweed Solanum mauritianum Scop. relative to the indigenous Solanum species in Natal/KwaZulu and the Transkei. Journal of the Entomological Society of South Africa 54:489-494.

Petrides, G. A. 1972. A field guide to trees and shrubs: northeastern and north-central United States and southeastern and south-central Canada. Houghton Mifflin Company, Boston, Massachusetts.

Pimentel, D., L. Lach, R. Zuniga, and D. Morrison. 2000. Environmental and economic costs of nonindigenous species in the United States. BioScience 50:53-65.

Pringle, J. S. 1973. Lonicera maackii (Caprifoliaceae) adventive in Ontario. The Canadian Fieldnaturalist 8:54-55.

Rehder, A. 1903. Synopsis of the genus Lonicera. Missouri Botanical Garden Annual Report 1903:27-232.

Rehder, A. 1940. A manual of cultivated trees and shrubs. 2nd edition. MacMillan Publishing Company, New York, New York.

Reichard, S. H., and P. White. 2001. Horticulture as a pathway of invasive plant introductions in the United States. BioScience 51:103-113.

Ripley, T. H., R. A. Cookingham, and R. P. Corrinet. 1957. Black locust for quail in Massachusetts. Journal of Wildlife Management 21:459.

Rodewald, P. G., and M. C. Brittingham. 2004. Stopover habitats of landbirds during fall: use of edge-dominated and early successional forests. Auk 121:1040-1055. 
Samways, M. J., P. M. Caldwell, and R. Osborn. 1996. Ground-living invertebrate assemblages in native, planted and invasive vegetation in South Africa. Agriculture, Ecosystems and Environment 59:19-32.

Schierenbeck, K. A., R. N. Mack, and R. R. Sharitz. 1994. Effects of herbivory on growth and biomass allocation in native and introduced species of Lonicera. Ecology 75:1661-1672.

Schmidt, K. A., and C. J. Whelan. 1999. Effects of exotic Lonicera and Rhamnus on songbird nest predation. Conservation Biology 13:1502-1506.

Schopmeyer, C. S. 1974. Seeds of woody plants in the United States. Forest Service, U.S. Department of Agriculture, Washington D.C.

Sharp, W. C., and C. R. Belcher. 1981. 'Rem-Red' Amur honeysuckle - a multipurpose landscape shrub. American Nurseryman 153:7, 94-95.

Siemann, E., and W. E. Rogers. 2003. Herbivory, disease, and recruitment limitation, and success of alien and native tree species. Ecology 84:1489-1505.

Sinclair, W. A., H. H. Lyon, and W. T. Johnson. 1987. Diseases of trees and shrubs. Comstock Publishing Associates, Cornell University Press, Ithaca, New York.

Skulman, B. W., J. D. Mattice, M. D. Cain, and E. E. Gbur. 2004. Evidence for allelopathic interference of Japanese honeysuckle (Lonicera japonica) to loblolly and shortleaf pine regeneration. Weed Science 52:433-439.

Slobodchikoff, C. N., and J. T. Doyen. 1977. Effects of Ammophila arenaria on sand dune arthropod communities. Ecology 58:1171-1175.

Smith, R. H. 1964. Some experimental shrub plantings: 20 years later. New York Fish and Game Journal 11:91-105. 
Sosebee, R. E. 1983. Physiological, phenological, and environment considerations in brush and weed control. Pages 27-44 in Proceedings of the Brush Management Symposium, Albuquerque, NM, 16 February 1983. Texas Tech Press, Lubbock.

Southwick, E. E., G. M. Loper, and S. E. Sadwick. 1981. Nectar production, composition, energetics and pollinator attractiveness in spring flowers of western New York. American Journal of Botany 68:994-1002.

Tallamy, D. M. 2004. Do alien plants reduce insect biomass? Conservation Biology 18:16891692.

Tennessee Exotic Pest Plant Council. 1996. Tennessee exotic plant management manual. Available from http://www.webriver.com/tn-eppc (accessed February 2005).

Tewksbury, L., R. Casagrande, B. Bloosey, P. Häfliger, and M. Schwarzländer. 2002. Potential for biological control of Phragmites australis in North America. Biological Control 23:191-212.

Todd, R. 1985. Honeysuckle controlled by hand pulling (Illinois). Restoration and Management Notes 3:18.

Trisel, D. E., and D. L. Gorchov. 1994. Regional distribution, ecological impact, and leaf phenology of the invasive shrub, Lonicera maackii. Bulletin of the Ecological Society of America 75(Supplement):231-232.

Trisel, D. E. 1997. The invasive shrub, Lonicera maackii (Rupr.) Herder (Caprifoliaceae): factors contributing to its success and its effect on native species. PhD. Dissertation. Miami University, Oxford, Ohio. 
VanDruff, L. W., E. G. Bolen, and G. J. San Julian. 1996. Management of urban wildlife. Pages 507-530 in T. A. Bookhout, editor. Research and management techniques for wildlife and habitats, 5th edition. The Wildlife Society. Allen Press, Inc., Lawrence, Kansas.

Vellend, M. 2002. A pest and an invader: white-tailed deer (Odocoileus virginianus Zimm.) as a seed dispersal agent for honeysuckle shrubs (Lonicera L.). Natural Areas Journal 22:230234.

Vitousek, P. M., L. R. Walker, L. D. Whiteaker, D. Mueller-Dombois, and P. A. Matson. 1987. Biological invasion by Myrica faya alters ecosystem development in Hawaii. Science 238:802-804.

Wade, G. L. 1985. Success of trees and shrubs in an 18-year old planting on mine soil. U.S. Forest Service, Northeastern Forest Experiment Station, Broomall, Pennsylvania.

Weis, A. E., and M. R. Berenbaum. 1988. Herbivorous insects and green plants. Pages 123-162 in W. G. Abrahamson, editor. Plant-animal interactions: a textbook. McGraw-Hill, New York, New York.

Westbrooks, R. 1998. Invasive plants, changing the landscape of America: fact book. Federal Interagency Committee for the Management of Noxious and Exotic Weeds (FICMNEW), Washington D.C.

Western Pennsylvania Conservancy. 2003. Plant community mapping and surveys for species of special concern at Allegheny Portage Railroad National Historic Site, Johnstown Flood National Memorial, Fort Necessity National Battlefield, and Friendship Hill National Historic Site. Unpublished report.

Whelan, C. J., and M. L. Dilger. 1992. Invasive, exotic shrubs: a paradox for natural area managers? Natural Areas Journal 12:109-110. 
White, D. W., and E. W. Stiles. 1992. Bird dispersal of fruits in species introduced into eastern North America. Canadian Journal of Botany 70:1689-1696.

Wilcove, D. S., D. Rothstein, J. Dubow, A. Phillips, and E. Losos. 1998. Quantifying threats to imperiled species in the United States. BioScience 48:607-615.

Williams, C. E., J. J. Ralley, and D. H. Taylor. 1992. Consumption of seeds of the invasive Amur honeysuckle, Lonicera maackii (Rupr.) Maxim., by small mammals. Natural Areas Journal 12:86-89.

Williams, C. E. 1999. Fruits of alien shrubs and deer mice: a test of the persistent fruit defense hypothesis. Journal of the Pennsylvania Academy of Science 73:33-37.

Williamson, M. 1996. Biological invasives. Chapman \& Hall, London, United Kindgom.

Wilson, E. O. 1987. The little things that run the world (the importance and conservation of invertebrates). Conservation Biology 1:344-346.

Witmer, M. C. 1996. Consequences of an alien shrub on the plumage coloration and ecology of Cedar Waxwings. Auk 113:735-743.

Witmer, M. C., and P. J. Van Soest. 1998. Contrasting digestive strategies of fruit-eating birds. Functional Ecology 12:728-741.

Woods, K. D. 1993. Effects of invasion by Lonicera tatarica L. on herbs and tree seedlings in four New England forests. American Midland Naturalist 130:62-74.

Yasunaga, T. 1997. A new mirine plant bug (Heteroptera: Miridae) found in Kyushu Island, Japan and the southern Primorski Kraj, Russia. The Entomologist 116:116-121.

Yemm, E. W., and A. J. Willis. 1954. The estimation of carbohydrates in plant extracts by anthrone. Biochemical Journal 57:508-514. 
Zavaleta, E. 2000. Valuing ecosystem services lost to Tamarix invasion in the United States.

Pages 261-300 in H. A. Mooney and R. J. Hobbs, editors. Invasive species in a changing world. Island Press, Washington D.C. 

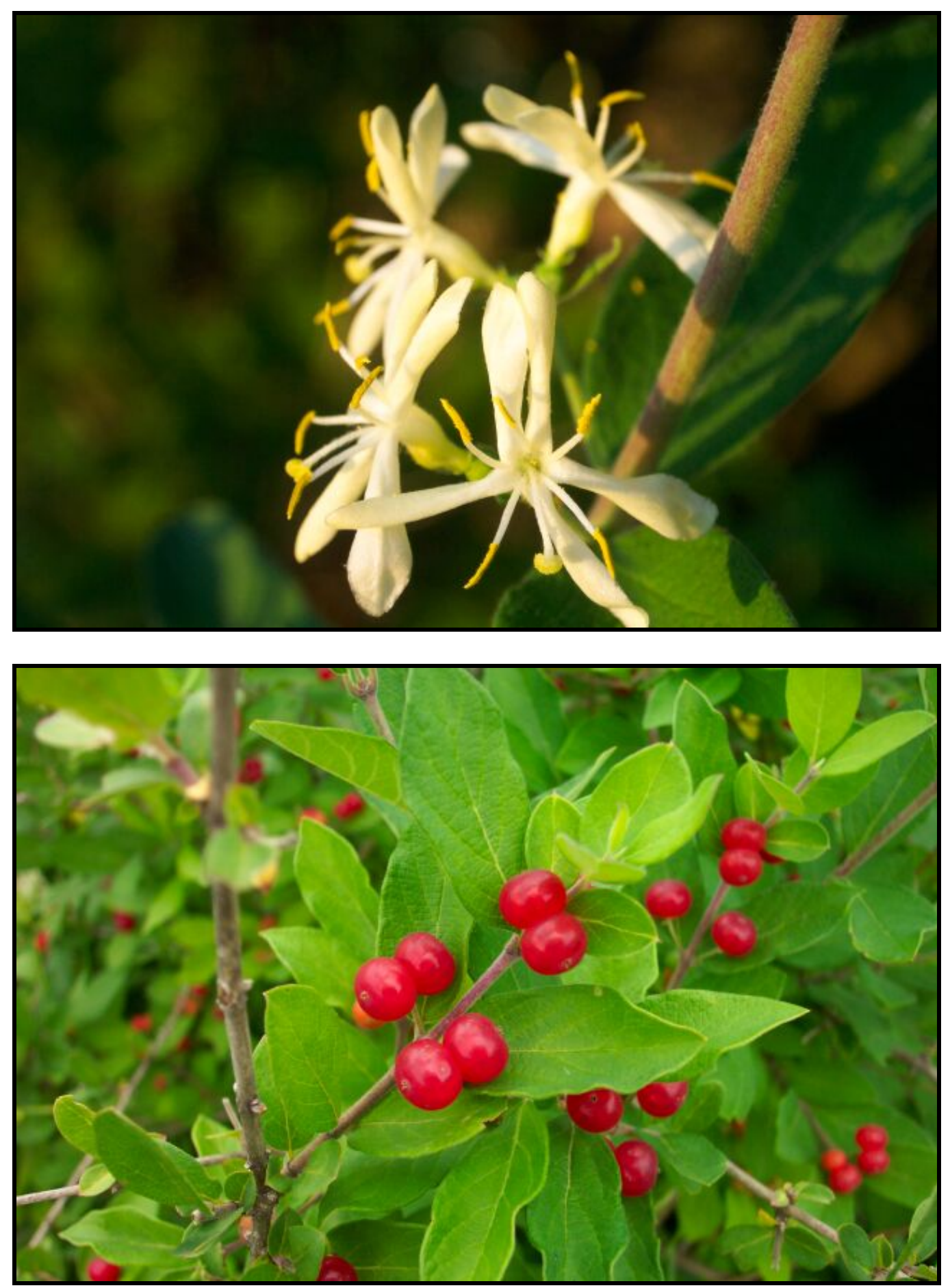

Figure 1. Lonicera morrowii (Morrow's honeysuckle) blooms May-June and has white flowers that later fade to yellow (top). When mature, the paired fruits of Morrow's honeysuckle are glabrous and red (bottom). 


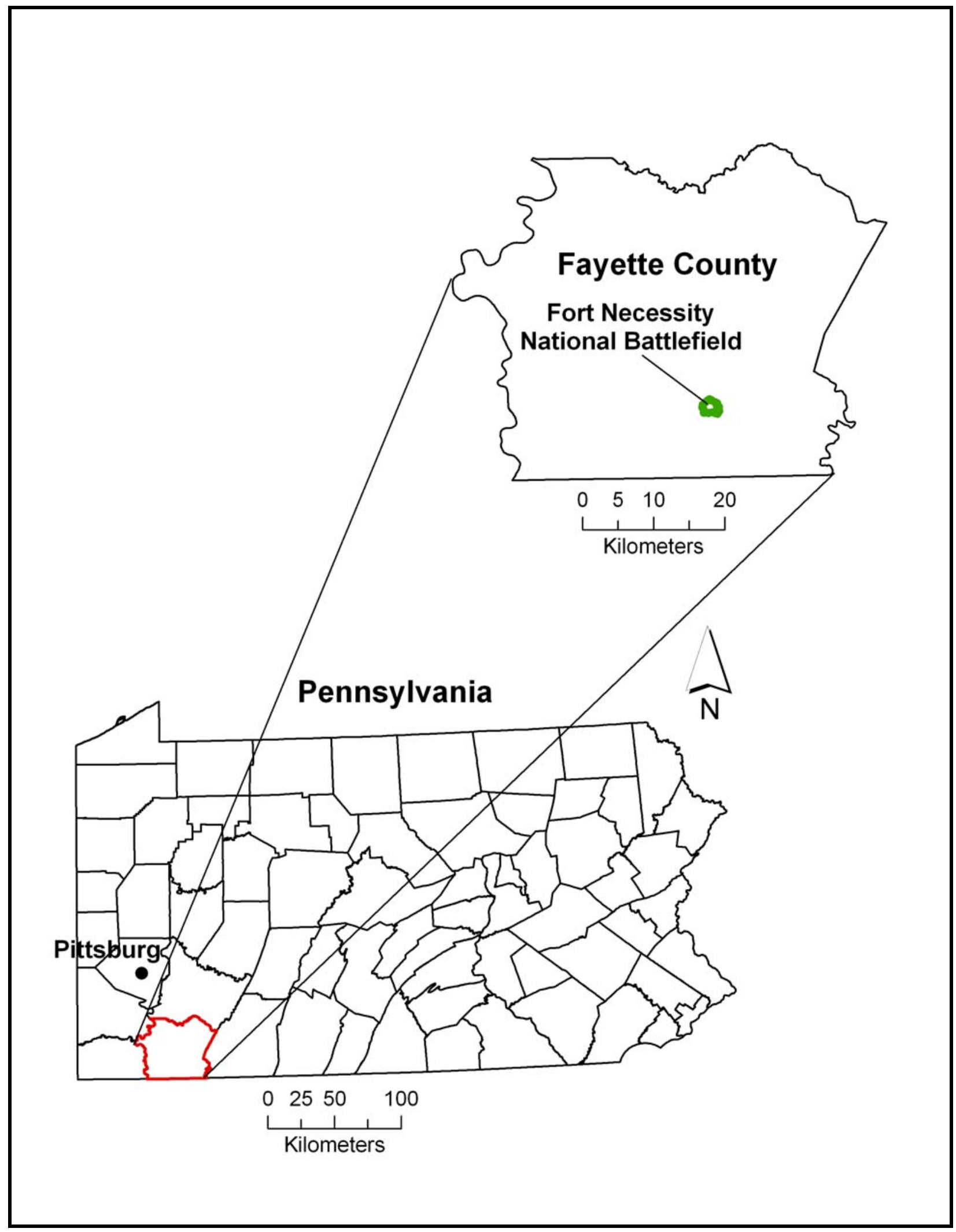

Figure 2. Fort Necessity National Battlefield lies in Fayette County, southwestern Pennsylvania. 


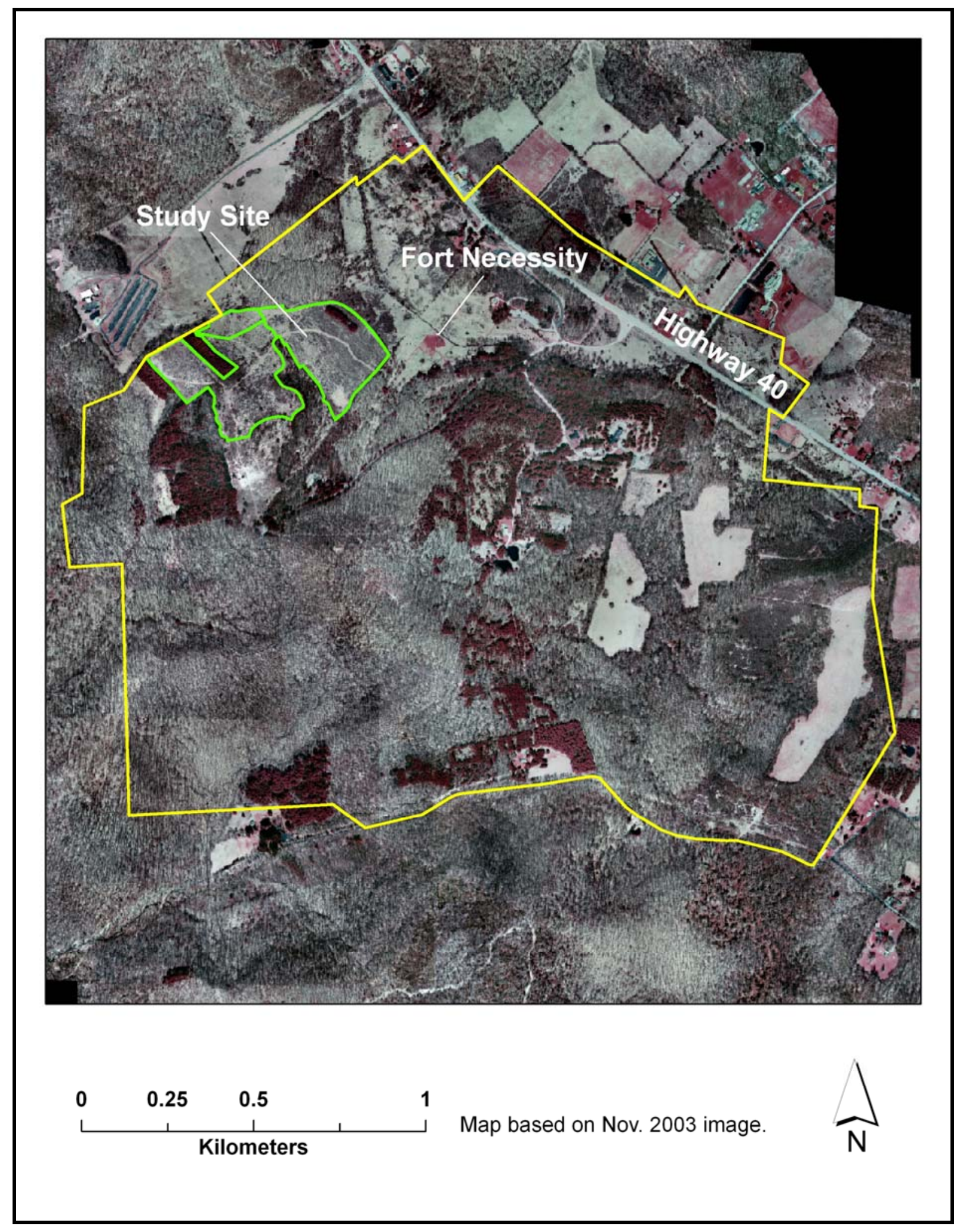

Figure 3. The study site is located within the 350.5 ha Fort Necessity National Battlefield. The site lies adjacent to the replica of Fort Necessity, the central historical attraction at the park. 


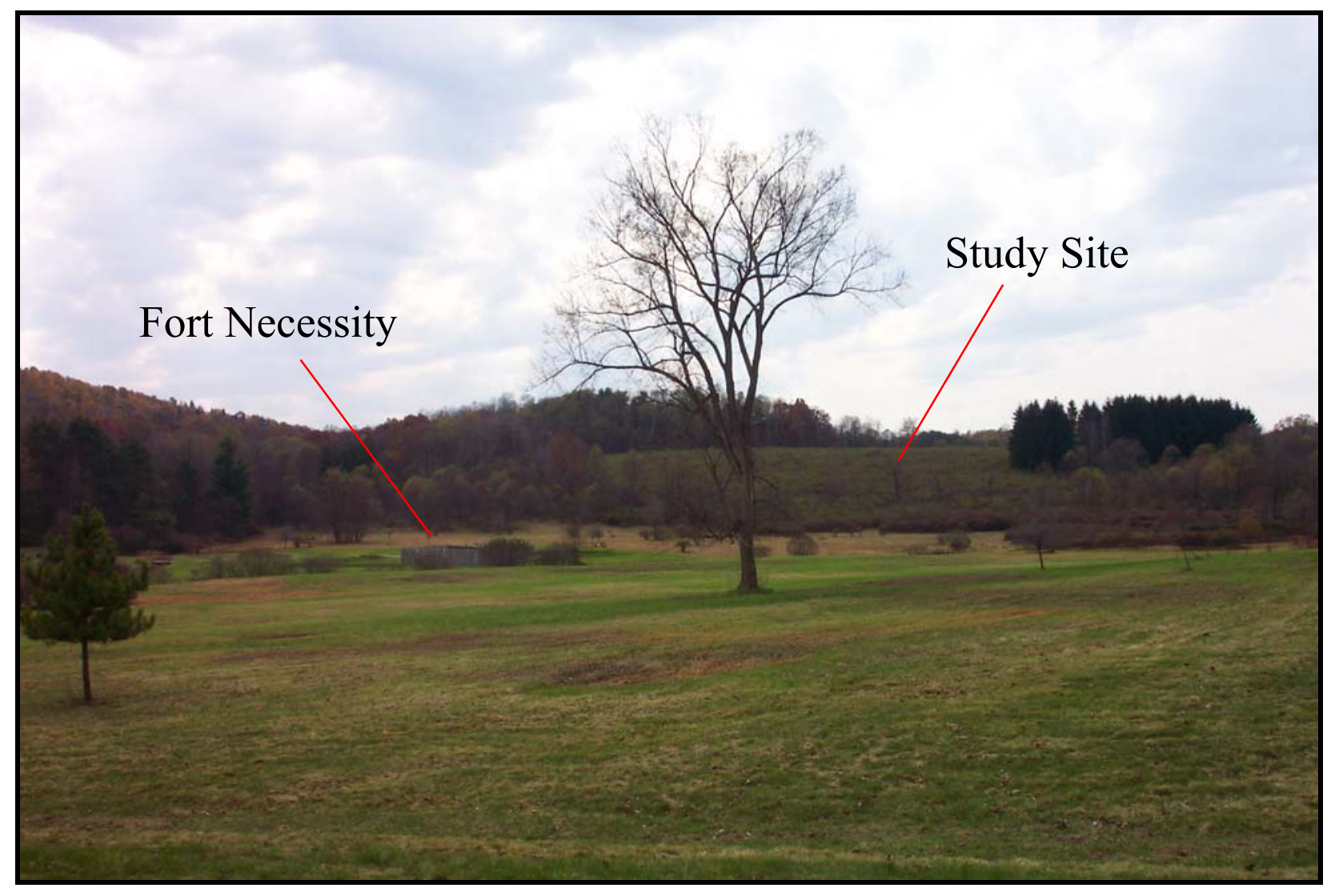

Figure 4. The study site overlooks the replica of Fort Necessity. Morrow's honeysuckle dominates the study site and has impeded natural regeneration of the hardwood forest. 

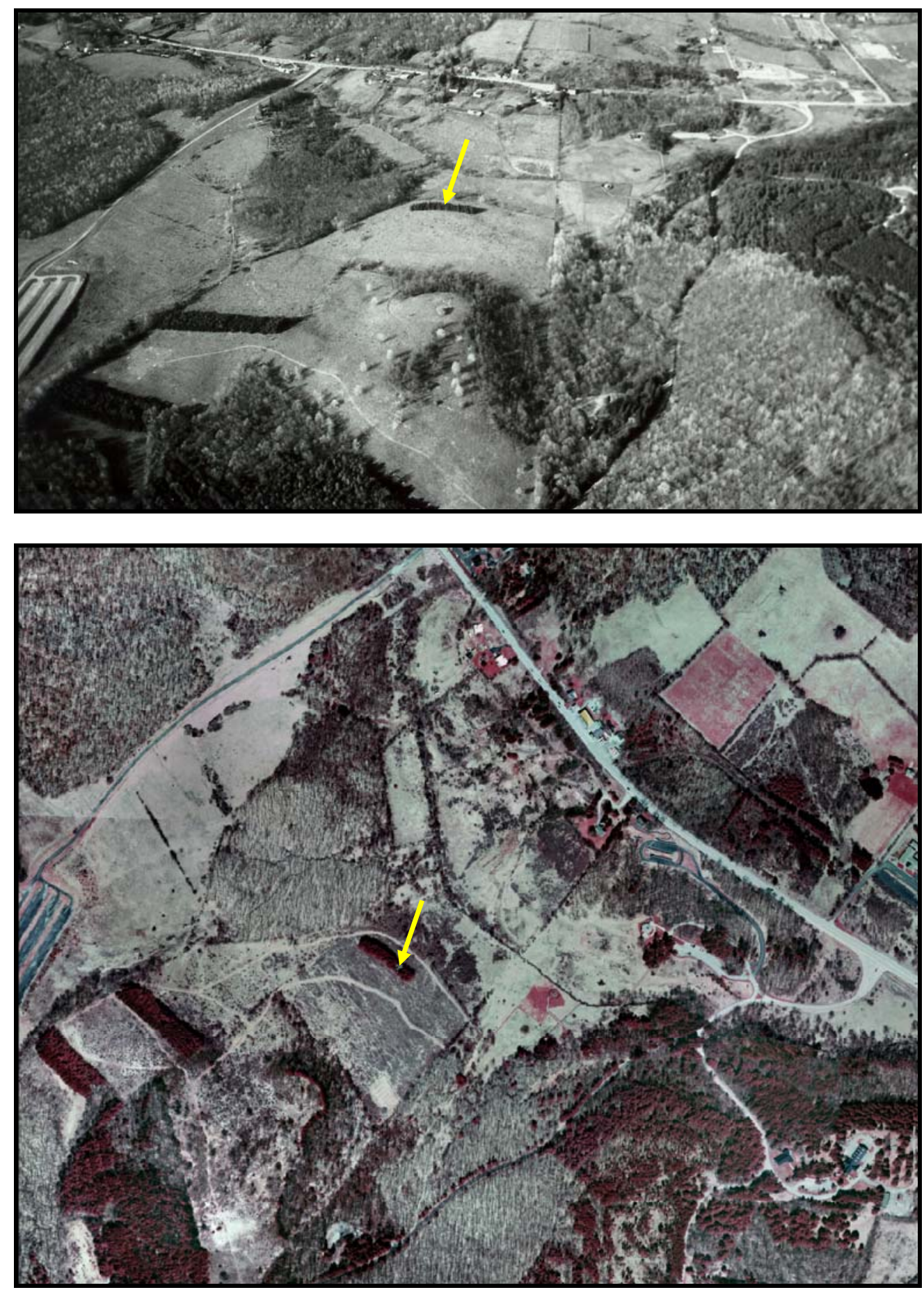

Figure 5. An aerial photograph (circa 1985) reveals that the study area contained few shrubs (top). However, when mowing ceased, Morrow's honeysuckle invaded the site and now dominates the study area, as seen from this 2003 aerial photo (bottom). Yellow arrows point to an isolated spruce stand for reference. 


\title{
CHAPTER 2
}

\section{SEASONAL EFFECTS OF FOUR REMOVAL METHODS ON THE INVASIVE LONICERA MORROWII (MORROW'S HONEYSUCKLE) AND INITIAL RESPONSES OF UNDERSTORY PLANTS IN A SOUTHWESTERN PENNSYLVANIA OLD FIELD}

Jason P. Love ${ }^{1}$ and James T. Anderson ${ }^{1,2}$

\begin{abstract}
The first step in restoration often involves the removal of invasive plants, but little research has focused on responses of plant communities to control methods. The shrub Lonicera morrowii Gray (Morrow's honeysuckle) is one of a suite of exotic bush honeysuckle species that have become some of the most pervasive woody invaders in eastern North America. In 2004, we tested four removal methods (cut, mechanical removal, stump application of glyphosate, and foliar application of glyphosate) carried out during late spring and early fall within a degraded meadow at Fort Necessity National Battlefield, Pennsylvania, United States. We established 45 $5 \times 5-\mathrm{m}$ plots to measure woody species; 5 plots of each treatment method were treated in spring, while the remaining 5 were treated in autumn. We maintained 5 control plots. Prior to removal, mean density of Morrow's honeysuckle was 67,920 \pm 4,480 shrubs/ha. Foliar application of herbicide and mechanical removal were the most effective at reducing the number of shrubs ( $\geq 62 \%)$. Overall our treatment methods were less successful (26-68\% reduction) than
\end{abstract}

This chapter written in the style of Restoration Ecology.

\footnotetext{
${ }^{1}$ Division of Forestry and Natural Resources, West Virginia University, Morgantown, WV 26506, U.S.A.

${ }^{2}$ Address correspondence to J. T. Anderson, email wetland@wvu.edu
} 
other reported control efforts of bush honeysuckles; the sheer number of shrubs coupled with the open habitat in which they were growing made control efforts difficult. Spring treatments, particularly cut and mechanical treatments, had higher metrics of herbaceous community quality. However, continued restoration efforts, including Odocoileus virginianus (white-tailed deer) control and the planting of native seeds and saplings, should be employed to favor the establishment of native seedlings and herbs.

Key words: alien species, disturbance, early successional habitat, exotic species, Fort Necessity National Battlefield, glyphosate, herbaceous layer, herbicide, invasive plants, meadow, nonnative, Roundup, understory

\section{Introduction}

As human population and commerce continue to grow and expand, exotic plants continue to invade and spread, depressing native diversity and altering ecological functions (e.g., Manchester \& Bullock 2000; Ehrenfield 2003). Lonicera morrowii (Morrow's honeysuckle), a shrub native to Japan, was introduced to the United States as an ornamental circa 1875 (Rehder 1940). The shrub is one of a suite of closely-related bush honeysuckles originally introduced into North America for horticultural purposes, including L. maackii (Amur honeysuckle), L. tatarica (tatarian honeysuckle), and L. × bella (Bell's honeysuckle) (Rehder 1940; Luken \& Thieret 1995). Since their introduction, exotic bush honeysuckles have been planted as shelterbelts in the Midwest (Herman \& Davidson 1997), used in mine reclamation (Wade 1985), and planted for wildlife use (Martin et al. 1951; Ripley et al. 1957; VanDruff et al. 1996). In North America, Morrow's honeysuckle occupies a wide range of sites, including riparian areas and disturbed 
areas such as railroad rights-of-ways, roadsides, and abandoned agricultural land (Hauser 1966; Barnes \& Cottam 1974). The shrubs occur in both interior forests and forest edges (Barnes \& Cottam 1974). Today, Morrow's honeysuckle is naturalized in most northeastern and midAtlantic states, as well as southeastern and south-central Canada (Batcher \& Stiles 2000).

Numerous studies reveal that exotic bush honeysuckles decrease herbaceous diversity (Woods 1993; Hutchinson \& Vankat 1997; Medley 1997; Collier et al. 2002), herbaceous cover (Woods 1993; Hutchinson \& Vankat 1997; Luken et al. 1997; Medley 1997; Collier et al. 2002), and fitness of herbaceous species (Gould \& Gorchov 2000; Miller \& Gorchov 2004). The shrubs also inhibit forest regeneration (Woods 1993; Hutchinson \& Vankat 1997; Medley 1997;

Gorchov \& Trisel 2003; Hartman \& McCarthy 2004). Moreover, bush honeysuckles negatively affect nesting songbirds (Schmidt \& Whelan 1999; Borgmann \& Rodewald 2004), herpetofauna (McEvoy \& Durtsche 2004), spider richness (Buddle et al. 2004), and invertebrate diversity, abundance, and biomass (Chapter 3).

Despite the shrubs' deleterious effects on native flora and fauna, new varieties of bush honeysuckles are being produced (Sharp \& Belcher 1981; Dirr 1990; Luken \& Thieret 1996) and the shrubs continue to be purposely propagated and marketed (Dirr 1990; VanDruff et al. 1996; Herman \& Davidson 1997). While ecologists and land managers are trying to find ways to control exotic bush honeysuckle (e.g., Luken \& Mattimiro 1991; Hartman \& McCarthy 2004), horticulturalists are engaging in conflicting studies that attempt to increase the shrubs' resilience to pests (Mahr \& Dittl 1986; Herman \& Davidson 1997). Several eradication methods have been attempted by researchers and land managers, including pulling the shrubs (Todd 1985; Nyboer 1992; Gayek 2000; C. Ranson 2004, Fort Necessity National Battlefield, Farmington, Pennsylvania, personal communication), clipping or cutting the shrubs (Luken \& Mattimiro 
1991; Nyboer 1992; Batcher \& Stiles 2000), foliar application of herbicides (Lynn et al. 1979; Nyboer 1992; Conover \& Geiger 1993), and stump application or stem injection of herbicides (Henderson \& Howell 1981; Kline 1981; Kline et al. 1982; Nyboer 1992; Franz \& Keiffer 2000; Hartman \& McCarthy 2004) (see Chapter 1 for review of honeysuckle control measures). Few rigorous studies of these methods have been performed (Luken \& Mattimiro 1991; Hartman \& McCarthy 2004) and only one study quantitatively compared multiple control techniques on bush honeysuckle (Hartman \& McCarthy 2004), making it difficult to determine which method is ultimately the most effective. Moreover, all published studies discuss methods for controlling Amur honeysuckle specifically or suggestions for controlling bush honeysuckles in general. Morrow's honeysuckle, while closely related to Amur honeysuckle, may have different physiological traits that allow it to respond differently to eradication efforts.

The timing of treatments can often be critical in determining the effectiveness of control efforts (e.g., Lynn et al. 1979; Franz \& Keifer 2000). Levels of total nonstructural carbohydrates (TNC) fluctuate according to the plants' phenological stage (i.e., dormant, bud break, flowering, fruiting, leaf senescence, leaf abscission) (Loescher et al. 1990). Relating TNC levels to the plants' phenological stage may aid in determining the most effective period for control efforts. For instance, controlling plants by either cutting the stems at the base or pulling the shrub up at the roots is most effective in late spring or early summer, immediately after the leaves have emerged. Following leaf emergence, TNC levels are at their lowest, the carbohydrates having been exhausted during the production and growth of the new leaves; once cut or mechanically removed, the plant has few TNC reserves left to sprout. In contrast, the best time to apply a foliar or cut-stump application of herbicide occurs immediately prior to leaf abscission in the autumn, when TNC levels are at their highest. During this period, the plants translocate 
carbohydrates to roots for storage; herbicides applied during this period also become translocated down to roots, permitting the herbicides to work more effectively (Sosebee 1983).

The type and timing of treatments also may influence the response of herbaceous vegetation. This is important because successful restoration includes not only the eradication of the invasive plant, but also the overall diversity (Sinclair et al. 1995) and composition (Harrington 1999) of the plant community after the invasive plant has been eradicated. If efforts used to control the invasive plant negatively affect native vegetation, then the treatment type may not be worthwhile even though the method may be successful in eradicating the invasive plant. For example, applying a foliar application of herbicide to bush honeysuckle during summer also may kill desirable native understory vegetation. However, if the foliar application occurs just prior to leaf abscission in the fall, the treatment may spare native understory plants since many are dormant during this period (Conover \& Geiger 1993).

Our objectives for this study were to 1) monitor the TNC levels of Morrow's honeysuckle roots over the course of the year and relate these levels to the shrubs' phenological stage; 2) compare four different eradication methods for Morrow's honeysuckle based on spring and autumn treatments, when TNC levels are at their lowest and highest respectively; 3) assess the response of understory flora based on the type and timing of the different control methods; and 4) determine the most effective eradication method based on the response of Morrow's honeysuckle, the response of understory plants, and the amount of labor and cost for each of the control methods. 


\section{Methods}

\section{Study Site}

This study was conducted on Fort Necessity National Battlefield, Fayette County, southwestern Pennsylvania, U.S.A. $\left(39^{\circ} 48^{\prime} 43^{\prime \prime} \mathrm{N} \times 84^{\circ} 41^{\prime} 50^{\prime \prime} \mathrm{W}\right)$, a 350.5 ha park located $95 \mathrm{~km}$ southeast of Pittsburgh, Pennsylvania. Fort Necessity National Battlefield lies in the Allegheny Mountain subregion of the Appalachian Plateau in an area known as the southern Laurel Highlands (Fort Necessity National Battlefield 1991). The study site was located on an upper, level portion of hillside west of the replication of Fort Necessity, a hastily-built fort constructed by George Washington and his troops in 1754 at the onset of the French-Indian War. The hillside was cleared for livestock grazing prior to the establishment of the park in 1933 (Fort Necessity National Battlefield 1991). The National Park Service maintained the 14.6 ha pasture by periodic mowing until the mid-1980s, at which time mowing ceased in an attempt to restore the site to its historic condition through passive management.

It was thought that through the process of natural succession, the pasture would be eventually reforested by native hardwoods (C. Ranson 2004, Fort Necessity National Battlefield, Farmington, Pennsylvania, personal communication). However, before reforestation could occur, Morrow's honeysuckle invaded the site, forming a dense monoculture (Figure 1) (Fort Necessity National Battlefield 1991). Pollen samples taken from cores near the fort reveal that Quercus spp. (oaks), Carya spp. (hickories), Betula spp. (birch), Fagus grandifolia (American beech), and Acer rubrum (red maple) were the major components of the forest prior to clearing (Kelso 1994).

The study site is characterized by Brinkerton and Armagh silt loams with 3-8\% slopes. Soils are moderately deep, moderate to well drained, medium textured, and underlain by acidic shale and sandstone bedrock (Kopas 1973). The climate is moderate continental. Average 
annual temperature is $9^{\circ} \mathrm{C}$, with mean winter temperature of $-3^{\circ} \mathrm{C}$ and mean summer temperature of $22^{\circ} \mathrm{C}$. Average annual precipitation is $119 \mathrm{~cm}$ (Fort Necessity National Battlefield 1991).

\section{Total Nonstructural Carbohydrates}

We randomly selected five Morrow's honeysuckle shrubs per month (March 2004 - February 2005) and collected taproot samples using a pulaski to pry shrubs from the ground and loppers to cut the roots. Prior to collection, the phenological stage (e.g., dormant, bud break, fruit formation, leaf senescence, leaf abscission) of the plant was noted (Sosebee 1983; Conway et al. 1999). Roots were placed on dry ice to prevent enzymatic degradation of the total nonstructural carbohydrates during transportation back to the lab (Bóo \& Pettit 1975). Roots were dried in an oven at $100^{\circ} \mathrm{C}$ for $1-2$ hours. Afterwards, roots were dried at $60-65^{\circ} \mathrm{C}$ for one week to remove moisture (Bóo \& Pettit 1975). After drying, roots were carefully cleaned of bark, soil, and heartwood. Remaining sapwood was ground in a Wiley mill (Thomas Scientific, Hoboken, NJ, U.S.A.) fitted with a $1 \mathrm{~mm}$ screen.

Ground Morrow's honeysuckle roots were analyzed using the anthrone reagent procedure (Yemm \& Willis 1954; Conway et al. 1999). We took two $0.5 \mathrm{~g}$ subsamples of each individual root sample and digested each subsample by boiling $60 \mathrm{ml}$ of $\mathrm{HCl}$ in $300 \mathrm{ml}$ flasks for $2 \mathrm{hrs}$. If there was significant variability $(>10 \%)$ between the two subsamples, a third subsample was processed and analyzed. After digestion, we cooled and filtered the samples into $100 \mathrm{ml}$ volumetric flasks using Whatman No. 2 filter paper. Each flask was then brought to volume using distilled water. A $1 \mathrm{ml}$ aliquot was removed and placed into a $35 \mathrm{ml}$ test tube containing 4 $\mathrm{ml}$ of distilled water. A Thermolyne vortex mixer (Barnstead International, Dubuque, IA, U.S.A.) was used to shake the mixture for 30 seconds. Afterwards, a $1 \mathrm{ml}$ aliquot was removed from the original test tube and placed into a $35 \mathrm{ml}$ test tube with $10 \mathrm{ml}$ of anthrone reagent. Test 
tubes were shaken for 30 seconds using a Thermolyne vortex mixer. Test tubes were then placed in a heater block for 17 minutes at $96-100^{\circ} \mathrm{C}$. Next, samples were placed into a cold-water bath until they reached room temperature. Once samples reached room temperature, the mixture was analyzed using a Hitachi U-1500 UV/VIS spectrophotometer (Hitachi High Technologies America, Inc., San Jose, CA, U.S.A.) set at 612 nm, using glucose as the standard. Total nonstructural carbohydrates were calculated by dividing the sample spectrophotometric readings by the glucose standard to obtain a percent $\mathrm{TNC}$ value on a dry $\mathrm{mg} / \mathrm{g}$ basis. For interpretation, we charted the TNC levels throughout the year and related the measurements to the shrubs' phenological stage. We used the resulting graph to denote the most effective time to apply herbicide or mechanically remove the shrub.

\section{Removal Methods}

We tested four different methods of removing Morrow's honeysuckle: 1) mechanical removal; 2) foliar application of glyphosate herbicide (Roundup Pro; Monsanto, St. Louis, MO, U.S.A.); 3) stump application of glyphosate herbicide; and 4) cutting the shrub flush to the ground. We had $105 \times 5$-m plots of each treatment type, including five control plots in which no vegetation was treated, for a total of 45 plots. We established a buffer of $5 \mathrm{~m}$ between plots to ensure that treatments did not interfere with one another. Plots were located $>10 \mathrm{~m}$ from the forest edge. The location of the first plot was randomly placed; thereafter, plots were systematically placed among five linear, parallel blocks. Each block contained nine plots - two plots of each of the four treatment types and one randomly assigned control plot. Treatments were systematically assigned among plots from a series generated from random selection (no replacement) of the four treatment methods. This design resulted in a more even distribution of treatments compared to a completely randomized design. Because of time and logistical constraints, we were not able to 
randomly assign the month of treatment. Instead, we treated the first 2.5 blocks in late spring (16-28 May) and the remaining 2.5 blocks in early autumn (9-15 September) in 2004.

Mechanical removal was accomplished by prying shrubs with a pulaski and pulling up the plants by hand. Care was taken to remove all large roots to prevent sprouting (Nyboer 1992). We performed foliar application on calm days when there was little chance of rain. We used a standard backpack sprayer set at high pressure to apply a $2 \%$ glyphosate solution to shrub foliage. We used a chainsaw to cut Morrow's honeysuckle in cut treatments and cut-stump herbicide plots. Shrubs were cut approximately $5 \mathrm{~cm}$ above the ground and removed from the plot. We used a backpack sprayer filled with a $20 \%$ solution of glyphosate and set the sprayer at low pressure to treat cut stumps. We evaluated cost and time (person-hrs) of each method on a per-hectare basis.

We estimated percent cover of pre- and post-treatment Morrow's honeysuckle by dividing each plot into four equal quadrants, estimating the percent cover within each quadrant, and averaging the percent cover of the four quadrants to the nearest $5 \%$. Within each $5 \times 5-\mathrm{m}$ plot, we identified woody vegetation (including tree seedlings) to species and counted stems. Using calipers, we measured basal diameters of all woody stems to the nearest millimeter. For pre-treatment surveys, we noted whether each stem was dead or alive. During the post-treatment sampling, we counted the number of sprouts emerging from the base of shrubs; because of the great number and uniform diameter of sprouts, we did not measure their diameters. We noted whether woody stems or sprouts originated from a common point (i.e., part of the same shrub) or occurred singly. We also noted whether the woody species were native or exotic. All pretreatment measurements were performed during the 3-4 weeks prior to treatments, while post- 
treatment measurements were performed during the same period the following year (i.e., during spring for spring treatments and late summer for the autumn treatments).

\section{Response of Understory Plants}

We established five $1 \times 1$-m subplots within each of the $455 \times 5$-m shrub plots; four subplots were located in the corners of each plot and the remaining subplot was located in the center of each plot. We identified to species and estimated percent cover of all herbaceous vegetation, as well as woody vegetation $<0.5 \mathrm{~m}$ in height. We measured understory vegetation a few days prior to treatment; plots were remeasured in May 2005 to identify spring ephemerals, and again in August 2005 when goldenrod (Solidago spp.) and asters (Symphyotrichum spp.) were easier to identify. We noted whether understory species were native or exotic. Nomenclature follows Kartesz (1999).

\section{Statistical Analyses}

Differences of total nonstructural carbohydrate concentrations among phenological stages (dependent variable) were analyzed using analysis of variance (ANOVA) for unequal sample sizes (PROC GLM, SAS version 9.1; SAS Institute, Inc., Cary, NC, U.S.A.); Duncan's multiple range tests were used for post hoc pairwise comparisons. Phenological stage of development was the independent variable. Prior to analysis, we tested TNC data for normality. Two outliers were present in the TNC data; during the processing of the roots, it was noted that these two roots were likely dead prior to collection. Consequently, these data points were removed to achieve normality prior to statistical analysis.

When analyzing the success of Morrow's honeysuckle removal methods, post-treatment Morrow's honeysuckle shrub cover, stem density, shrub density, and native shrub density were 
the dependent variables; the independent variables were the season and method of treatment. We assumed that change in honeysuckle cover, stem density, shrub density, and native shrub density was the result of the season and treatment method. We also assumed that environmental conditions (e.g., soil nutrient content, moisture level, etc.) were not significantly different among plots. Pre-treatment Morrow's honeysuckle shrub cover, stem density, shrub density, and native shrub density metrics were used as covariates when comparing mean post-treatment cover, stem density, shrub density, and native stem density among the different treatments and seasons. We tested the homogeneity of slope for the covariates (pre-treatment metrics) versus the dependent variables (post-treatment metrics) and found that there was no significant difference in the posttreatment and pre-treatment relationship as a function of season or treatment $(p>0.05)$ (Appendix Ia). Once these assumptions were met, we compared Morrow's honeysuckle percent posttreatment shrub cover, stem density, shrub density, and native shrub density using analysis of covariance (ANCOVA) (PROC GLM, SAS version 9.1); we used Duncan's multiple range tests to compare differences between pairs. We used paired t-tests (PROC TTEST, SAS version 9.1) to compare pre- and post-Morrow's honeysuckle shrub cover, stem density, shrub density, and native shrub density. We tested all variables for normality; percent shrub cover did not meet assumptions of normality even after transformations, so we ranked the data (PROC RANK, SAS version 9.1) prior to analysis. Data transformed into ranks are thought more likely to satisfy assumptions of the parametric model than would the original data (Conover \& Iman 1981). Stem density data were log-transformed to meet assumptions of normality. Morrow's honeysuckle and native shrub density data were square-root transformed.

We used species richness $(S)$, Shannon-Weiner Index of diversity $\left(H^{\prime}\right)$ (Shannon \& Weaver 1949), Pielou (1966) evenness index ( $\left.J^{\prime}\right)$, and Floristic Quality Assessment Index to 
evaluate differences in the herbaceous layer between pre- and post-treatment, between seasons, and among treatments. We used coefficient of conservatism (C) values developed for plants in West Virginia (J. Rentch 2005, West Virginia University, Morgantown, unpublished data) to determine mean C and Floristic Quality Index (FQI) scores for pre-treatment herb subplots, as well as post-treatment herb subplots. The Floristic Quality Index is a somewhat subjective, but still quantitative, measurement of an herbaceous community's quality (Swink \& Wilhelm 1994). A species' coefficient of conservatism value (from 0-10) reflects the ecological specializations that a plant displays to a specific habitat or set of environmental conditions; the herbaceous quality of an area is a function of the richness of conservative plant species. A floristic quality assessment has two separate measures: 1) the average coefficient of conservatism, or mean C, which is calculated by taking the sum of the coefficient of conservatism values and dividing them by the number of native species, and 2) the Floristic Quality Index, which is calculated by multiplying the mean $\mathrm{C}$ by the square-root of the total number of native species. We followed the recommendations of Bernthal (2003) and reported both mean C and FQI scores.

The independent variables in the statistical model were season and treatment. We used ANOVA (PROC GLM, SAS version 9.1) to compare pre-treatment and post-treatment means between seasons, among treatments, and to determine whether treatment effects were confounded with seasons; we used Duncan's multiple range tests to compare differences between pairs. We used paired t-tests (PROC TTEST, SAS version 9.1) to compare pre- and postherbaceous community metrics. We tested the normality of all variables; variables that were not normal were transformed using the following: arcsine square-root (pre-treatment exotic cover and $J^{\prime}$ ), square-root (post-treatment native cover, exotic cover, and native richness), square (posttreatment $H^{\prime}$ ), and arcsine transformations raised to the fourth power (post-treatment $J^{\prime}$ ). When 
performing t-tests, the following transformations were executed on both pre- and post-treatment data to achieve normality: square-root (total cover and total richness), log (native cover, exotic cover, and FQI), square-root log (native richness), and arcsine transformations raised to the fourth power $\left(J^{\prime}\right)$. Untransformed means and SEs are reported throughout the results. Level of significance for all tests was set at $\alpha=0.05$.

\section{Results}

\section{Total Nonstructural Carbohydrates}

Mean total nonstructural carbohydrate levels among phenological stages were significantly different $\left(\mathrm{F}_{[5,52]}=10.22, p<0.001\right)$ (Appendix IIa). Total nonstructural carbohydrate levels were lowest in May immediately after leaf and flower formation; TNC levels were highest in October as leaves were beginning to senesce (Figure 2).

\section{Removal Methods}

Prior to shrub removal, there were no differences among treatment methods for Morrow's honeysuckle cover, stem density, or shrub density $\left(\mathrm{F}_{[4,35]} \leq 0.95, p \geq 0.445\right)$ and there were no interactions between season and treatment $\left(\mathrm{F}_{[4,35]} \leq 1.78, p \geq 0.155\right)$. There also was no difference in pre-treatment stem density or shrub density between seasons $\left(\mathrm{F}_{[1,35]} \leq 4.10\right.$, $p \geq 0.051)$. Honeysuckle cover in plots treated in spring were lower than autumn treated plots (F $[1,35]=10.20, p=0.003)$; however, this was expected since pre-treatment cover was measured in the few weeks prior to when treatments were applied, a period when shrubs in the spring are still not fully leafed-out (Table 1; Appendix IIIa, IVa, \& Va). Mean ( $\pm \mathrm{SE})$ live Morrow’s honeysuckle pre-treatment stem density was $441.5 \pm 24.9$ stems/plot $(176,000 \pm 9,960$ stems/ha); mean density of dead Morrow's honeysuckle stems was $188.1 \pm 11.9$ stems/plot $(75,240 \pm 4,760$ 
stems/ha). Mean density ( \pm SE) of Morrow's honeysuckle shrubs was $169.8 \pm 11.2$ shrubs/plot $(67,920 \pm 4,480 \mathrm{shrubs} / \mathrm{ha})$. Mean diameter $( \pm \mathrm{SE})$ of live Morrow’s honeysuckle stems was $7.49 \pm 0.15 \mathrm{~mm}$, while dead stems averaged $6.26 \pm 0.12 \mathrm{~mm}$.

Following removal, we found significant differences in honeysuckle cover, stem density, and shrub density between seasons $\left(\mathrm{F}_{[1,34]} \geq 12.07, p \leq 0.001\right)$, among treatments $\left(\mathrm{F}_{[4,34]} \geq 19.68\right.$, $p \leq 0.001)$, and there was a differential effect of treatment in spring and autumn $\left(\mathrm{F}_{[4,34]} \geq 4.21, p \leq\right.$ 0.007). Moreover, there were significant differences in honeysuckle cover, stem density, and shrub density between pre- and post-treatments for both season and treatments $(|\mathrm{t}| \geq 2.49, p \leq$ 0.035), with the exception of honeysuckle cover of control treatments and stem density of stump treatments $(|\mathrm{t}| \leq 2.16, p \geq 0.097)$ (Table 1; Appendix IIIa, IVa, \& Va). Mechanical removal in spring was the most effective method for reducing cover, stem density, and shrub density of Morrow's honeysuckle (Figure 3). Cutting the shrubs in autumn was the least effective at reducing cover and shrub density. Stump application of glyphosate was the least effective at reducing the number of honeysuckle stems, followed by cutting the shrubs in autumn (Figure 3). For all post-treatment methods, sprouts made up $>98 \%$ of all live Morrow's honeysuckle stems, except for foliar-spring(73.6\%) and foliar-autumn (86.6\%) (Appendix VIa).

We identified 21 woody species prior to testing our removal methods (Appendix VIIa). Two species, Rosa multiflora (multiflora rose) (747 \pm 286 stems/ha) and Berberis thunbergii (Japanese barberry) (53 stems/ha), were exotic. Prior to removing Morrow's honeysuckle, we found no significant difference in mean number of native shrubs between seasons $\left(\mathrm{F}_{[1,35]}=0.23\right.$, $p=0.631)$, among treatments $\left(\mathrm{F}_{[4,35]}=0.15, p=0.961\right)$, or among season $\times$ treatment interactions $\left(\mathrm{F}_{[4,35]}=1.42, p=0.248\right)$ (Table 1; Appendix IIIa, IVa, \& Va). The 5 most common native woody species were Acer rubrum (red maple) $(3,400 \pm 1960$ stems/ha), 
Viburnum recognitum (southern arrowwood) (3,197 \pm 587 stems/ha), Crataegus pruinosa (waxyfruit hawthorne) $(1,536 \pm 199$ stems/ha), Prunus serotina (black cherry) $(1,456 \pm 208$ stems/ha), and Malus coronaria (sweet crabapple) (729 \pm 160 stems/ha). Exotic woody species (excluding Morrow's honeysuckle) accounted for $0.4 \%$ of all live stems, while native woody species accounted for $6.0 \%$ of all live stems. Morrow's honeysuckle accounted for $93.6 \%$ of all live stems.

Following shrub removal, the number and type of native woody species varied according to season and treatment, though no novel native woody plants were recorded. However, two previously unrecorded exotic woody species, Elaeagnus umbellata (autumn olive) ( $n=2$ plots) and Ailanthus altissima (tree of heaven) $(n=2$ plots) were recorded (Appendix VIIIa). Posttreatment native shrub density did not differ significantly between seasons $\left(\mathrm{F}_{[1,12]}=1.19, p=\right.$ $0.118)$, or among treatments $\left(\mathrm{F}_{[4,12]}=1.43, p=0.284\right)$, nor were the season $\times$ treatment interactions significant $\left(\mathrm{F}_{[4,12]}=2.19, p=0.132\right)$. Moreover, there were no significant differences between pre- and post-treatments $(|\mathrm{t}| \leq 1.67, p \geq 0.091)$, with the exception of stump treatments $(\mathrm{t}=2.80, p=0.021)$ (Table 1; Appendix IIIa, IVa, \& Va). Exotic species (excluding Morrow's honeysuckle) accounted for $<3.0 \%$ of all woody stems. Native woody stems accounted for $<9.1 \%$ of all woody stems, with the exception of mechanical-spring plots, where native woody stems accounted for $46.9 \%$ of all live stems. Morrow's honeysuckle accounted for $>90 \%$ of all woody stems for all season-treatment combinations, except for spring mechanical removal plots, where Morrow's honeysuckle was reduced to $53.1 \%$ of all woody stems (Appendix IXa). 
The time and cost of each of the four treatment methods varied (Table 2). Foliar application of herbicide was the least time-consuming treatment, as well as the least expensive. Mechanical removal was the most time-consuming and costly.

\section{Response of Understory Plants}

Prior to removal, there were no differences among treatments for herbaceous metrics $\left(\mathrm{F}_{[4,35]}\right.$ $\leq 1.33, p \geq 0.278)$ and there were no interactions between season and treatment $\left(\mathrm{F}_{[4,35]} \leq 1.98\right.$, $p \geq 0.120$ ). There also was no difference in total herbaceous cover, native cover, exotic cover, native richness, evenness $\left(J^{\prime}\right)$, mean coefficient of conservatism (mean C), or Floristic Quality Index (FQI) scores between seasons $\left(\mathrm{F}_{[1,35]} \leq 1.47, p \geq 0.234\right)$, though total richness, exotic richness, and diversity $\left(H^{\prime}\right)$ were significantly higher in plots treated in autumn than plots treated in spring $\left(\mathrm{F}_{[1,35]} \geq 7.61 .30, p<0.009\right)$ (Table 3; Appendix Xa, XIa, \& XIIa).

We identified 93 herbaceous species during our pre-treatment survey (Appendix XIIIa). The five species having the greatest pre-treatment percent cover were Anthoxanthum odoratum (sweet vernal grass) $(\overline{\mathrm{X}}=8.46 \%)$, Solidago rugosa $($ wrinkleleaf goldenrod) $(\overline{\mathrm{X}}=3.51 \%), S$. juncea (early goldenrod) $(\overline{\mathrm{X}}=2.64 \%)$, Rubus flagellaris (northern dewberry) $(\overline{\mathrm{X}}=1.96 \%)$, and Dactylis glomerata (orchard grass) $(\overline{\mathrm{X}}=1.88 \%)$. Both sweet vernal grass and orchard grass are exotic cool season grasses. One species, Elymus trachycaulus (slender wheatgrass) $(n=1$

subplot), is a state-listed species, having a state rank of S3. Species with this rank are considered vulnerable to extirpation in the state due to their scarcity and typically have 21 to 100 known occurrences in the state (Pennsylvania Natural Heritage Program, http://www.naturalheritage.state.pa.us/, accessed March 2006). 
Following honeysuckle removal, there were significant differences between seasons for all herbaceous plant metrics $\left(\mathrm{F}_{[1,35]} \geq 15.46, p<0.001\right)$, with the exception of exotic herbaceous cover, exotic richness, and mean $\mathrm{C}\left(\mathrm{F}_{[1,35]} \leq 2.09, p \geq 0.157\right)$. There were also significant differences among treatments for all metrics $\left(\mathrm{F}_{[4,35]} \geq 6.39, p<0.001\right)$, with the exception of mean $\mathrm{C}\left(\mathrm{F}_{[4,35]}=0.86, p=0.497\right)$. There were significant season $\times$ treatment interaction for exotic cover and FQI scores $\left(\mathrm{F}_{[4,35]} \geq 2.71, p \leq 0.046\right)$, while total cover, native cover, total richness, native richness, exotic richness, $H^{\prime}, J^{\prime}$, and mean $\mathrm{C}$ had no season $\times$ treatment interaction $\left(\mathrm{F}_{[4,35]}\right.$ $\leq 2.21, p \geq 0.087)$. There were significant differences between pre- and post-treatment herbaceous community metrics, though this trend was not consistent among all variables and metrics (Table 3 \& Figure 4; Appendix Xa, XIa, \& XIIa).

We recorded a total of 102 species in post-treatment herb plots; 70 species were native and 32 species were exotic. Notable new exotic species include Polygonum persicaria (spotted ladysthumb) ( $n=2$ subplots) and Bromus inermis (smooth brome) ( $n=9$ subplots). Overall, post-treatment native species richness increased by $2.9 \%$, while exotic species richness increased by $28.0 \%$. The state-ranked species, slender wheatgrass ( $n=1$ subplot), was recorded in posttreatment surveys. A list of all pre- and post-treatment herbaceous and woody species, their exotic/native status, and their coefficient of conservatism values can be found in Appendix XIVa.

\section{Discussion}

Total nonstructural carbohydrate (TNC) levels of Morrow's honeysuckle followed trends similar to other woody species (Bóo \& Pettit 1975; Menke \& Trlica 1981; Conway et al. 1999). At our study site, Morrow's honeysuckle was one of the first shrubs to leaf and flower and one of the 
last shrubs to undergo leaf senescence, a characteristic noted in other exotic bush honeysuckle species (Harrington et al. 1989a; Woods 1993). Managers can maximize their efforts at controlling Morrow's honeysuckle if they time their control efforts to coincide when total nonstructural levels are at their lowest, immediately after leaf and flower formation. Cut treatment and mechanical treatment of Morrow's honeysuckle were most successful in spring, when TNC levels were at their lowest. We also found success of both stump and foliar application of glyphosate to be greater in spring; however, previous studies reported that application of herbicide is most effective later in the growing season (Lynn et al. 1979; Nyboer 1992). Cutting the shrubs in spring, when carbohydrate reserves were at their lowest, caused the plant to have fewer numbers of sprouts compared to autumn treatments, when carbohydrate reserves were higher. The application of glyphosate to the exposed stumps caused little additional mortality to shrubs; there were no significant differences in shrub cover, stem densities, or shrub densities between cut and stump treatments in spring and between cut and stump treatments in autumn. Stump application of herbicide in autumn resulted in the greatest number of stems (a $342 \%$ increase from pre-treatment stem density); this was partly a reflection of the herbicide causing numerous stunted sprouts, or 'witches brooms,' on some of the stumps, a condition also noted on Amur honeysuckle stumps treated with glyphosate (Conover \& Geiger 1993). Foliar application of herbicide may have had less success in autumn because of stress caused by the fungus Insolibasidium deformans (Auriculariaceae) (fungus id confirmed by W. MacDonald 2004, West Virginia University, Morgantown). This blight, found only on the genus Lonicera, causes a crinkling and browning of the leaves (Sinclair et al. 1987), a condition that may impact the uptake and subsequent translocation of the herbicide (Lynn et al. 1979). Morrow's honeysuckle shrubs infected with this fungus became more common later in the 
growing season. However we also believe late-season timing for herbicide application of bush honeysuckles may be overstated. Hartman and McCarthy (2004) had $\geq 94 \%$ stem mortality rates on Amur honeysuckle stems treated in March for both EZJect application of glyphosate pellets and stump application of glyphosate. We suspect our decreased rates of success (26-68\% reduction in the number of shrubs) for controlling Morrow's honeysuckle relative to other bush honeysuckle removal studies relate to 1) the extremely high densities of shrubs at our study site, 2) the open habitat in which shrubs at our study site were growing, and 3) our focus on Morrow's honeysuckle, which might have different physiological traits compared to other species of bush honeysuckle that have been studied. Compared to Hartman and McCarthy (2004), we had nearly three times as many honeysuckle stems (176,000 vs. $65,959 / \mathrm{ha})$ and shrubs $(67,920 \mathrm{vs.}$ 21,380/ha). These high densities may have prevented complete foliar coverage of herbicide on smaller shrubs growing underneath the main canopies of the larger shrubs, making complete coverage difficult. Previous studies have noted increased vigor of exotic bush honeysuckles growing in areas exposed to full sunlight relative to those growing under forested canopies (Luken 1988; Harrington et al. 1989a, 1989b; Luken 1990; Luken \& Mattimiro 1991; Luken et al. 1997). The increased carbohydrate reserves available to open-grown bush honeysuckle shrubs make complete eradication more difficult. For example, Luken (1990) reported that repeated clipping of Amur honeysuckle shrubs growing under a forest canopy killed $70 \%$ of shrubs, while the same treatment with shrubs growing in open canopies yielded only $10 \%$ mortality.

Overall, mechanical removal was the most effective method to reduce shrub cover, stem density, and shrub density. However, this treatment method required the most amount of labor and as a result, had the second highest costs. Trisel (1997) also found that prying Amur 
honeysuckle shrubs with a pulaski was a successful method ( $98 \%$ mortality), but was labor intensive. The least effective methods were cutting the shrubs and stump application of herbicide. Cutting in autumn reduced plant densities by only $13.8 \%$, while stump application reduced shrub densities by $29.1 \%$. Our results for stump application are in sharp contrast to Kline (1981), who found that a $20 \%$ solution of glyphosate applied to Bell's honeysuckle stumps in the fall resulted in an $89 \%$ mortality rate. In our study, stump application of glyphosate was the most expensive method, since it not only took many hours of labor to cut the shrubs, but also required more herbicide ( $20 \%$ solution compared to $2 \%$ foliar solution). The labor required for stump application of herbicide ( $467 \mathrm{hrs} / \mathrm{ha}$ ) was greater than that reported from another study (170 hrs/ha) (Henderson \& Howell 1981); this difference was probably a result of the greater number of stems that had to be treated within our study plots.

Our results revealed that it is important to have several metrics to measure the success of control efforts. Using just one metric, such as cover, may mask any real effects of removal methods. For example, all of the treatments showed $\geq 69 \%$ reduction of shrub cover; if we used only this metric to measure success, we would greatly overestimate the success of some of the removal methods, since shrub densities for these same treatments were reduced $\leq 68 \%$. If we used stem densities as a measure of success, we would underestimate the success of the different control methods, because only 2 out of 4 treatments actually reduced the number of Morrow's honeysuckle stems and two treatments (cut and stump) actually increased the number of stems $\geq 122 \%$ because of prolific sprouting. We believe shrub densities were the best estimate to measure success; treatments were significantly different, but all reduced the number of shrubs. Future studies examining the effects of control options should explicitly state which metrics were 
measured to determine success and should take into account the possibility of reaching different conclusions based on the use and interpretation of different metrics.

While differences in native shrub density among treatments after removal were not statistically significant, there was a trend of decreasing native shrub densities following treatments, with the exception of cut in autumn treatments. All stump and foliar treatments of herbicide decreased native shrub density. Though we attempted to direct the herbicide spray towards Morrow's honeysuckle and away from native shrubs, some of the smaller, inconspicuous seedlings were inadvertently sprayed, leading to an overall decrease in native shrubs in these treatments. However, cut and mechanical treatments also showed signs of decreased native shrub numbers; this may be related to high Odocoileus virginianus (white-tailed deer) densities at Fort Necessity National Park (Yahner et al. 2004). We saw several native shrubs that showed signs of browse after being released from the dense thickets of Morrow's honeysuckle. Deer browsing might be responsible for an overall decrease in native shrub densities in treated plots; control plots had an overall increase in native shrub densities, possibly a result of the dense thickets of Morrow's honeysuckle limiting access to browsing deer. Though the shoots of exotic bush honeysuckles may confer some protection from deer browsing, other studies have shown that the shrubs have an overall negative effect on native woody species (Gorchov \& Trisel 2003; Hartman \& McCarthy 2004). The negative effects of overabundant deer herds in natural areas has been well-researched (e.g., Warren 1991; Stromayer \& Warren 1997; Vellend 2002) and is a problem that will need to be addressed at Fort Necessity National Battlefield if post-eradication restoration efforts are to be successful.

Metrics of herbaceous community quality were maximized in mechanical and cut treatments. Moreover, plots treated in spring had higher measures of herbaceous community 
quality compared to plots treated in autumn. Spring treatments had an extra growing season to recover and regenerate; this might explain why these metrics were higher in spring treated plots. Plots sprayed with herbicide had reduced metrics of herbaceous community quality, particularly foliar applications performed in autumn. Plants sprayed during this season are not yet dormant, so it is not surprising that the herbaceous community was reduced as a result of the herbicide. Trisel (1997) also noted a severe reduction of non-target herbaceous species when herbicide was applied to Amur honeysuckle growing in a forest. To reduce mortality of understory species, other studies recommended spraying later in the year when understory plants were dormant, but the leaves of bush honeysuckle had not yet senesced (Nyboer 1992; Conover \& Geiger 1993). We decided to perform eradication measures earlier to avoid possible early frosts which often occur in this mountainous region of Pennsylvania (C. Ranson 2004, Fort Necessity National Battlefield, Farmington, Pennsylvania, personal communication). However, unlike other treatments, foliar application of glyphosate in autumn reduced richness and percent cover of exotic herbaceous species.

From one-third to two-thirds of herbaceous cover in all plots consisted of exotics. After treatments, new exotic species emerged, including aggressive invaders like tree of heaven and spotted ladysthumb. Removing the honeysuckle shrubs created a void for other exotic invaders to colonize, making selection of the "best" treatment method troublesome. Although we tried a wide array of removal techniques, and some of the techniques were successful in reducing Morrow's honeysuckle, none of the methods seemed to create conditions favorable for the establishment of native woody or herbaceous species. If restoration is to be successful, further post-eradication efforts, including deer control and planting of native seedlings and herbs, will 
have to be employed to shift current conditions so that they favor the long-term establishment and growth of natives.

\section{Acknowledgments}

Funding for this project was provided by the National Park Service and Fort Necessity National Battlefield. We thank the staff of Fort Necessity National Battlefield, especially C. Ranson, for her logistical support and advice. For assistance in the field, we thank J. Edalgo, J. E. Love, M. Hepner, R. Edalgo, J. Alexander, L. Bonner, B. Hoksch, K. Perkins, B. Crokus, A. Strippel, T. Swain, and the 2005 Student Conservation Association crew (H. Thomson, J. Rutherford, A. Paris, J. Marder, T. Neff, J. Zelle, R. Chan, D. Farrell, and D. Dwyer). C. Dacko and the West Virginia University Chemistry Department supplied dry ice for the project. We thank T. Webster and the West Virginia University Rumen Fermentation Lab for lab analysis of the honeysuckle root samples. W. Grafton spent many hours in the field and lab identifying plants.

J. Rentch provided valuable advice throughout the study. We thank G. Seidel, J. McGraw, and J. Rentch for advice on study design and statistics. J. McGraw and C. Ranson graciously reviewed earlier drafts of this manuscript. This is scientific article number XXXX of the West Virginia University Agricultural and Forestry Experiment Station.

\section{LITERATURE CITED}

Barnes, W. J., and G. Cottam. 1974. Some autoecological studies of the Lonicera $\times$ bella complex. Ecology 55:40-50.

Batcher, M. S., and S. A. Stiles. 2000. Element stewardship abstract for Lonicera maackii (Rupr.) Maxim (Amur honeysuckle), Lonicera morrowii A. Gray (Morrow’s 
honeysuckle), Lonicera tatarica L. (tatarian honeysuckle), Lonicera $\times$ bella Zabel (Bell's honeysuckle). The Nature Conservancy, Arlington, Virginia. Available from http://tncweeds.ucdavis.edu/esadocs/documnts/loni_sp.pdf (accessed October 2005).

Bernthal, T. W. 2003. Development of a floristic quality assessment methodology for Wisconsin. Report to the U.S. Environmental Protection Agency Region V, Chicago, Illinois.

Bóo, R. M., and R. D. Pettit. 1975. Carbohydrate reserves in roots of sand shin oak in west Texas. Journal of Range Management 28:469-472.

Borgmann, K. L., and A. D. Rodewald. 2004. Nest predation in an urbanizing landscape: the role of exotic shrubs. Ecological Applications 14:1757-1765.

Buddle, C. M., S. Higgins, and A. L. Rypstra. 2004. Ground-dwelling spider assemblages inhabiting riparian forests and hedgerows in an agricultural landscape. American Midland Naturalist 151:15-26.

Collier, M. H., J. L. Vankat, and M. R. Hughes. 2002. Diminished plant richness and abundance below Lonicera maackii, an invasive shrub. American Midland Naturalist 147:60-71.

Conover, D. G., and D. R. Geiger. 1993. Glyphosate controls Amur honeysuckle in native woodland restoration (Ohio). Restoration and Management Notes 11:168-169.

Conover, W. J., and R. L. Iman. 1981. Rank transformation as a bridge between parametric and nonparametric statistics. American Statistician 35:124-133.

Conway, W. C., L. M. Smith, R. E. Sosebee, and J. F. Bergan. 1999. Total nonstructural carbohydrate trends in Chinese tallow roots. Journal of Range Management 52:539-542.

Dirr, M. A. 1990. Manual of woody landscape plants: their identification, ornamental characteristics, culture, propagation, and uses. 4th edition. Stipes Publishing Company, Champaign, Illinois. 
Ehrenfield, J. G. 2003. Effects of exotic plant invasions on soil nutrient cycling processes. Ecosystems 6:503-523.

Fort Necessity National Battlefield. 1991. General Management Plan/Development Concept Plan/Interpretive Prospectus. Unpublished report.

Franz, C. R., and C. Keiffer. 2000. Effectiveness of the EZJect capsule injection system against the invasive shrub, Amur honeysuckle. The Ohio Woodland Journal 7:19-20.

Gayek, A. 2000. Effect of habitat variation on rate and success of colonization of two invasive shrubs, Lonicera maackii and Ligustrum vulgare, in a forested glen. MS Thesis. Ohio State University, Columbus.

Gorchov, D. L., and D. E. Trisel. 2003. Competitive effects of the invasive shrub, Lonicera maackii (Rupr.) Herder (Caprifoliaceae), on the growth and survival of native tree seedlings. Plant Ecology 166:13-24.

Gould, A. M. A., and D. L. Gorchov. 2000. Effects of the exotic invasive shrub Lonicera maackii on the survival and fecundity of three species of native annuals. American Midland Naturalist 144:36-50.

Harrington, R. A., B. J. Brown, and P. B. Reich. 1989a. Ecophysiology of exotic and native shrubs in southern Wisconsin: relationship of leaf characteristics, resource availability, and phenology to seasonal patterns of carbon gain. Oecologia 80:356-367.

Harrington, R. A., B. J. Brown, P. B. Reich, and J. H. Fownes. 1989b. Ecophysiology of exotic and native shrubs in southern Wisconsin: annual growth and carbon gain. Oecologia 80:368-373.

Harrington, C. A. 1999. Forests planted for ecosystem restoration or conservation. New Forests 17:175-190. 
Hartman, K. M., and B. C. McCarthy. 2004. Restoration of a forest understory after the removal of an invasive shrub, Amur honeysuckle (Lonicera maackii). Restoration Ecology 12:154-165.

Hauser, E. J. P. 1966. The natural occurrence of a hybrid honeysuckle $($ Lonicera $\times$ bella $)$ in Ohio and Michigan. Michigan Botanist 5:211-217.

Henderson, R., and E. Howell. 1981. Time and cost figures for honeysuckle control in a disturbed southern Wisconsin forest (Wisconsin). Restoration and Management Notes 1:18-19.

Herman, D. E., and C. G. Davidson. 1997. Evaluation of Lonicera taxa for honeysuckle aphid susceptibility, winter hardiness and use. Journal of Environmental Horticulture 15:177182.

Hutchinson, T. F., and J. L. Vankat. 1997. Invasibility and effects of Amur honeysuckle in southwestern Ohio forests. Conservation Biology 11:1117-1124.

Kartesz, J. T. 1999. Synthesis of the North American flora. Version 1.0. North Carolina Botanical Garden, Chapel Hill.

Kelso, G. K. 1994. Palynology in historical rural landscape studies: the pre-clearance forest border at Great Meadows, Pennsylvania. National Park Service, Technical Report NPS/MARFONE/NRTR - 95/067.

Kline, V. 1981. Control of honeysuckle and buckthorn in oak forests. Restoration and Management Notes 1:18.

Kline, V. M., G. Cottam, and T. Samingan. 1982. Response of oak woods understory plants to eradication of dense growth of an exotic invader, Lonicera $\times$ bella. Bulletin of the Ecological Society of America 63:102. 
Kopas, F. A. 1973. Soil survey of Fayette County, Pennsylvania. U.S. Department of Agriculture, Soil Conservation Service, U.S. Government Printing Office, Washington D.C.

Loescher, W. H., T. McCamant, and J. D. Keller. 1990. Carbohydrate reserves, translocation, and storage in woody plant roots. HortScience 25:274-281.

Luken, J. O. 1988. Population structure and biomass allocation of the naturalized shrub Lonicera maackii (Rupr.) Maxim. in forest and open habitats. American Midland Naturalist 119:258-267.

Luken, J. O. 1990. Forest and pasture communities respond differently to cutting of exotic Amur honeysuckle. Restoration and Management Notes 8:122-123.

Luken, J. O., and D. T. Mattimiro. 1991. Habitat-specific resilience of the invasive shrub Amur honeysuckle (Lonicera maackii) during repeated clipping. Ecological Applications 1:104109.

Luken, J. O., and J. W. Thieret. 1995. Amur honeysuckle (Lonicera maackii, Caprifoliaceae): its ascent, decline, and fall. Sida 16:479-503.

Luken, J. O., and J. W. Thieret. 1996. Amur honeysuckle, its fall from grace. BioScience 46:1824.

Luken, J. O., L. M. Kuddes, T. C. Tholemeier, and D. M. Haller. 1997. Comparative responses of Lonicera maackii (Amur honeysuckle) and Lindera benzoin (spicebush) to increased light. American Midland Naturalist 136:331-343.

Lynn, L. B., R. A. Rogers, and J. C. Graham. 1979. Response of woody species to glyphosate in northeastern states. Proceedings of the Northeastern Weed Science Society 33:336-342. 
Mahr, D. L., and T. G. Dittl. 1986. Chemical, natural, and cultural control of Hyadaphis tataricae (Homoptera: Aphididae) on honeysuckle. The Great Lakes Entomologist 19:91100.

Manchester, S. J., and J. M. Bullock. 2000. The impacts of non-native species on UK biodiversity and the effectiveness of control. Journal of Applied Ecology 37:845-864.

Martin, A. C., H. S. Zim, and A. L. Nelson. 1951. American wildlife and plants: a guide to wildlife food habits. Dover Publications, Inc., New York, New York.

McEvoy, N. L., and R. D. Durtsche. 2004. Effect of the invasive shrub Lonicera maackii (Caprifoliaceae; Amur honeysuckle) on autumn herptofauna biodiversity. Journal of the Kentucky Academy of Science 65:27-32.

Medley, K. E. 1997. Distribution of the non-native shrub Lonicera maackii in Kramer Woods, Ohio. Physical Geography 18:18-36.

Menke, J. W., and M. J. Trlica. 1981. Carbohydrate reserve, phenology, and growth cycles of nine Colorado range species. Journal of Range Management 34:269-277.

Miller, K. E., and D. L. Gorchov. 2004. The invasive shrub, Lonicera maackii, reduces growth and fecundity of perennial forest herbs. Oecologia 139:359-375.

Nyboer, R. 1992. Vegetation management guideline: bush honeysuckles - tatarian, Morrow's, Belle, and Amur honeysuckle (Lonicera tatarica L., L. morrowii Gray, L. $\times$ bella Zabel, and L. maackii [Rupr.] Maxim.). Natural Areas Journal 12:218-219.

Pielou, E. C. 1966. The measurement of diversity in different types of biological collections. Journal of Theoretical Biology 13:131-144.

Rehder, A. 1940. A manual of cultivated trees and shrubs. 2nd edition. MacMillan Publishing Company, New York, New York. 
Ripley, T. H., R. A. Cookingham, and R. P. Corrinet. 1957. Black locust for quail in Massachusetts. Journal of Wildlife Management 21:459.

Schmidt, K. A., and C. J. Whelan. 1999. Effects of exotic Lonicera and Rhamnus on songbird nest predation. Conservation Biology 13:1502-1506.

Shannon, C. E., and W. Weaver. 1949. The mathematical theory of communication. University of Illinois Press, Urbana, Illinois.

Sharp, W. C., and C. R. Belcher. 1981. 'Rem-Red' Amur honeysuckle - a multipurpose landscape shrub. American Nurseryman 153:7, 94-95.

Sinclair, A. R. E., D. S. Hik, O. J. Schmitz, G. G. E. Scudder, D. H. Turpin, and N. C. Larter. 1995. Biodiversity and the need for habitat renewal. Ecological Applications 5:579-587.

Sinclair, W. A., H. H. Lyon, and W. T. Johnson. 1987. Diseases of trees and shrubs. Comstock Publishing Associates, Cornell University Press, Ithaca, New York.

Sosebee, R. E. 1983. Physiological, phenological, and environmental considerations in brush and weed control. Pages 27-44 in Proceedings of the Brush Management Symposium. Albuquerque, New Mexico, 16 February 1983. Texas Tech Press, Lubbock.

Stromayer, K. A. K., and R. J. Warren. 1997. Are overabundant deer herds in the eastern United States creating alternate stable states in forest plant communities? Wildlife Society Bulletin 25:227-234.

Swink, F., and G. Wilhelm. 1994. Plants of the Chicago Region, 4th edition. Indiana Academy of Science, Indianapolis.

Todd, R. 1985. Honeysuckle controlled by hand pulling (Illinois). Restoration and Management Notes 3:18. 
Trisel, D. E. 1997. The invasive shrub, Lonicera maackii (Rupr.) Herder (Caprifoliaceae): factors leading to its success and its effect on native species. $\mathrm{PhD}$. Dissertation. Miami University, Oxford, Ohio.

VanDruff, L. W., E. G. Bolen, and G. J. San Julian. 1996. Management of urban wildlife. Pages 507-530 in T. A. Bookhout, editor. Research and management techniques for wildlife and habitats, 5th edition. The Wildlife Society. Allen Press, Inc., Lawrence, Kansas.

Vellend, M. 2002. A pest and an invader: white-tailed deer (Odocoileus virginianus Zimm.) as a seed dispersal agent for honeysuckle shrubs (Lonicera L.). Natural Areas Journal 22:230234.

Wade, G. L. 1985. Success of trees and shrubs in an 18-year old planting on mine soil. U.S. Forest Service, Northeastern Forest Experiment Station, Broomall, Pennsylvania.

Warren, R. J. 1991. Ecological justification for controlling deer populations in eastern national parks. Transactions of the 56th North American Wildlife and Natural Resources Conference 56:56-66.

Woods, K. D. 1993. Effects of invasion by Lonicera tatarica L. on herbs and tree seedlings in four New England forests. American Midland Naturalist 130:62-74.

Yahner, R. H., B. D. Ross, and J. E. Kubel. 2004. Comprehensive inventory of birds and mammals at Fort Necessity National Battlefield and Friendship Hill National Historic Site. U.S. Dept. of the Interior, National Park Service, Northeast Region, Philadelphia, Pennsylvania. Technical Report NPS/NERCHAL/NRTR-04/093.

Yemm, E. W., and A. J. Willis. 1954. The estimation of carbohydrates in plant extracts by anthrone. The Biochemical Journal 57:508-514. 
Table 1. Mean ( \pm SE) Morrow's honeysuckle cover, stem density, shrub density, and native shrub density per $5 \times 5-\mathrm{m}$ plot differed between pre- and post-treatment at Fort Necessity National Battlefield, Pennsylvania, U.S.A.

\begin{tabular}{|c|c|c|c|c|c|c|c|}
\hline \multirow[b]{3}{*}{ Variable } & \multirow[b]{3}{*}{$n$} & \multicolumn{3}{|c|}{ Morrow's honeysuckle cover ${ }^{1,2}$} & \multicolumn{3}{|c|}{ Morrow's honeysuckle stem density } \\
\hline & & Pre & Post & \multirow[b]{2}{*}{$\% \Delta^{3}$} & Pre & Post & \multirow[b]{2}{*}{$\% \Delta$} \\
\hline & & $\bar{X} \pm S E$ & $\bar{X} \pm S E$ & & $\bar{X} \pm S E$ & $\bar{X} \pm S E$ & \\
\hline \multicolumn{8}{|l|}{ Season } \\
\hline Spring & 23 & $0.77 \pm 0.03 \mathrm{Ba}$ & $0.17 \pm 0.06 \mathrm{Bb}$ & $-77.9 \%$ & $413 \pm 36 \mathrm{Aa}$ & $285 \pm 53 \mathrm{Bb}$ & $-31.0 \%$ \\
\hline Autumn & 22 & $0.88 \pm 0.02 \mathrm{Aa}$ & $0.31 \pm 0.07 \mathrm{Ab}$ & $-64.8 \%$ & $470 \pm 34 \mathrm{Ab}$ & $1,079 \pm 186 \mathrm{Aa}$ & $+129.6 \%$ \\
\hline \multicolumn{8}{|l|}{ Treatment } \\
\hline$\overline{\text { Control }}$ & 5 & $0.84 \pm 0.06 \mathrm{Aa}$ & $0.90 \pm 0.05 \mathrm{Aa}$ & $+7.1 \%$ & $364 \pm 56 \mathrm{Ab}$ & $477 \pm 58 \mathrm{Aa}$ & $+31.0 \%$ \\
\hline Cut & 10 & $0.85 \pm 0.04 \mathrm{Aa}$ & $0.26 \pm 0.10 \mathrm{Bb}$ & $-69.4 \%$ & $433 \pm 41 \mathrm{Ab}$ & $963 \pm 201 \mathrm{Aa}$ & $+122.4 \%$ \\
\hline Foliar & 10 & $0.83 \pm 0.07 \mathrm{Aa}$ & $0.10 \pm 0.04 \mathrm{BCb}$ & $-88.0 \%$ & $494 \pm 63 \mathrm{Aa}$ & $284 \pm 61 \mathrm{Bb}$ & $-42.5 \%$ \\
\hline Mechanical & 10 & $0.80 \pm 0.03 \mathrm{Aa}$ & $0.03 \pm 0.01 \mathrm{Cb}$ & $-96.3 \%$ & $398 \pm 57 \mathrm{Aa}$ & $199 \pm 70 \mathrm{Cb}$ & $-50.0 \%$ \\
\hline Stump & 10 & $0.80 \pm 0.04 \mathrm{Aa}$ & $0.22 \pm 0.07 \mathrm{Bb}$ & $-72.5 \%$ & $479 \pm 55 \mathrm{Aa}$ & $1,346 \pm 345 \mathrm{Aa}$ & $+181.0 \%$ \\
\hline
\end{tabular}


Table 1. Continued.

\begin{tabular}{|c|c|c|c|c|c|c|c|}
\hline \multirow[b]{3}{*}{ Variable } & \multirow[b]{3}{*}{$n$} & \multicolumn{3}{|c|}{ Morrow's honeysuckle shrub density } & \multicolumn{3}{|c|}{ Native shrub density } \\
\hline & & Pre & Post & & Pre & Post & \\
\hline & & $\bar{X} \pm S E$ & $\bar{X} \pm S E$ & $\% \Delta$ & $\bar{X} \pm S E$ & $\bar{X} \pm S E$ & $\% \Delta$ \\
\hline \multicolumn{8}{|l|}{ Season } \\
\hline Spring & 23 & $148 \pm 13 \mathrm{Aa}$ & $70 \pm 12 \mathrm{Bb}$ & $-52.7 \%$ & $24.4 \pm 3.3 \mathrm{Aa}$ & $22.4 \pm 3.4 \mathrm{Aa}$ & $-8.2 \%$ \\
\hline Autumn & 22 & $192 \pm 18 \mathrm{Aa}$ & $126 \pm 12 \mathrm{Ab}$ & $-34.4 \%$ & $21.4 \pm 3.1 \mathrm{Aa}$ & $18.1 \pm 2.4 \mathrm{Aa}$ & $-15.4 \%$ \\
\hline \multicolumn{8}{|l|}{ Treatment } \\
\hline Control & 5 & $152 \pm 29 \mathrm{Aa}$ & $175 \pm 24 \mathrm{Aa}$ & $+15.1 \%$ & $21.2 \pm 8.7 \mathrm{Aa}$ & $35.4 \pm 8.8 \mathrm{Aa}$ & $+67.0 \%$ \\
\hline Cut & 10 & $164 \pm 21 \mathrm{Aa}$ & $121 \pm 15 \mathrm{Bb}$ & $-26.2 \%$ & $22.8 \pm 3.4 \mathrm{Aa}$ & $26.2 \pm 4.9 \mathrm{Aa}$ & $-14.9 \%$ \\
\hline Foliar & 10 & $209 \pm 30 \mathrm{Aa}$ & $67 \pm 11 \mathrm{Cb}$ & $-67.9 \%$ & $20.6 \pm 4.3 \mathrm{Aa}$ & $14.6 \pm 3.8 \mathrm{Aa}$ & $-29.1 \%$ \\
\hline Mechanical & 10 & $143 \pm 20 \mathrm{Aa}$ & $55 \pm 16 \mathrm{Cb}$ & $-61.5 \%$ & $25.7 \pm 6.5 \mathrm{Aa}$ & $19.8 \pm 3.5 \mathrm{Aa}$ & $-23.0 \%$ \\
\hline Stump & 10 & $173 \pm 24 \mathrm{Aa}$ & $109 \pm 21 \mathrm{Bb}$ & $-58.7 \%$ & $23.6 \pm 4.8 \mathrm{Aa}$ & $13.0 \pm 2.0 \mathrm{Ab}$ & $-44.9 \%$ \\
\hline
\end{tabular}

${ }^{1}$ Means in a column (i.e., season and treatment) followed by different uppercase letters are significantly different $(p<0.05)$, based on Duncan's multiple range tests.

${ }^{2}$ Means in a row followed by different lowercase letters indicate significant differences $(p<0.05)$ between pre- and post-treatments based on paired t-tests.

${ }^{3}$ Percent change $(\% \Delta)$ indicates percent difference between pre- and post-treatment. 
Table 2. Foliar application of herbicide was the cheapest treatment method, while stump application of herbicide was the most expensive method to control Morrow's honeysuckle growing in a degraded meadow at Fort Necessity National Battlefield, Pennsylvania, U.S.A.

\begin{tabular}{lcccc}
\hline & Labor hrs./ha & Labor cost/ha & Equipment cost $/ \mathrm{ha}^{2}$ & Total cost/ha \\
\cline { 2 - 5 } Treatment & $\bar{X} \pm S E$ & $\bar{X} \pm S E$ & $\bar{X} \pm S E$ & $\bar{X} \pm S E$ \\
\hline Cut & $450 \pm 35$ & $\$ 4500 \pm \$ 350$ & $\$ 380 \pm \$ 40$ & $\$ 4880 \pm \$ 370$ \\
Foliar & $56 \pm 5$ & $\$ 560 \pm \$ 50$ & $\$ 210 \pm \$ 20$ & $\$ 770 \pm \$ 60$ \\
Mechanical & $933 \pm 81$ & $\$ 9330 \pm \$ 810$ & $\$ 0$ & $\$ 9330 \pm \$ 810$ \\
Stump & $467 \pm 30$ & $\$ 4670 \pm \$ 300$ & $\$ 4950 \pm \$ 30$ & $\$ 9620 \pm \$ 330$ \\
\hline
\end{tabular}

${ }^{1}$ Based on pay of $\$ 10 / \mathrm{hr}$.

${ }^{2}$ Based on: 2.5 gal of Roundup Pro $=\$ 158 ; 1$ gal bar oil $=\$ 6.95 ; 1$ gal mixed gas $=\$ 2.75$. Cost does not include sprayer, chainsaw, safety equipment, tools, or repair/maintenance costs. 
Table 3. Mean $( \pm \mathrm{SE})$ herbaceous variables per $5 \times 5$-m plot differed between pre- and post-treatment removal of Morrow's honeysuckle and among post-treatment methods at Fort Necessity National Battlefield, Pennsylvania, U.S.A.

\begin{tabular}{|c|c|c|c|c|c|c|c|}
\hline \multirow[b]{3}{*}{ Variable } & \multirow[b]{3}{*}{$n$} & \multicolumn{2}{|c|}{ Total cover $(\%)^{1,2}$} & \multicolumn{2}{|c|}{ Native cover $(\%)$} & \multicolumn{2}{|c|}{ Exotic cover $(\%)$} \\
\hline & & Pre & Post & Pre & Post & Pre & Post \\
\hline & & $\bar{X} \pm S E$ & $\bar{X} \pm S E$ & $\bar{X} \pm S E$ & $\bar{X} \pm S E$ & $\bar{X} \pm S E$ & $\overline{\bar{X}} \pm S E$ \\
\hline \multicolumn{8}{|l|}{ Season } \\
\hline Spring & 23 & $34.5 \pm 2.5 \mathrm{Ab}$ & $53.8 \pm 3.4 \mathrm{Aa}$ & $17.3 \pm 1.3 \mathrm{Ab}$ & $32.4 \pm 2.6 \mathrm{Aa}$ & $17.2 \pm 1.8 \mathrm{Ab}$ & $21.4 \pm 1.3 \mathrm{Aa}$ \\
\hline Autumn & 22 & $38.5 \pm 2.0 \mathrm{Aa}$ & $43.4 \pm 3.9 \mathrm{Ba}$ & $20.3 \pm 1.5 \mathrm{Aa}$ & $16.7 \pm 1.4 \mathrm{Bb}$ & $18.2 \pm 1.4 \mathrm{Aa}$ & $26.7 \pm 3.5 \mathrm{Aa}$ \\
\hline \multicolumn{8}{|l|}{ Treatment } \\
\hline Control & 5 & $32.9 \pm 3.5 \mathrm{Aa}$ & $31.1 \pm 3.7 \mathrm{Ca}$ & $15.2 \pm 2.2 \mathrm{Aa}$ & $18.0 \pm 2.9 \mathrm{Ba}$ & $17.6 \pm 2.2 \mathrm{Aa}$ & $13.0 \pm 0.8 \mathrm{Ca}$ \\
\hline Cut & 10 & $36.6 \pm 3.0 \mathrm{Ab}$ & $66.5 \pm 2.7 \mathrm{Aa}$ & $19.1 \pm 1.6 \mathrm{Aa}$ & $31.3 \pm 4.3 \mathrm{Aa}$ & $17.5 \pm 2.4 \mathrm{Ab}$ & $35.2 \pm 4.1 \mathrm{Aa}$ \\
\hline Foliar & 10 & $37.2 \pm 4.9 \mathrm{Aa}$ & $28.8 \pm 3.7 \mathrm{Ca}$ & $19.5 \pm 2.7 \mathrm{Aa}$ & $16.7 \pm 2.4 \mathrm{Ba}$ & $17.7 \pm 3.7 \mathrm{Aa}$ & $12.1 \pm 2.1 \mathrm{Ca}$ \\
\hline Mechanical & 10 & $34.3 \pm 3.2 \mathrm{Ab}$ & $54.1 \pm 3.6 \mathrm{Ba}$ & $16.3 \pm 1.8 \mathrm{Ab}$ & $29.9 \pm 3.7 \mathrm{Aa}$ & $18.0 \pm 2.1 \mathrm{Ab}$ & $24.2 \pm 1.8 \mathrm{Ba}$ \\
\hline Stump & 10 & $39.6 \pm 2.7 \mathrm{Ab}$ & $54.0 \pm 4.0 \mathrm{Ba}$ & $22.0 \pm 2.2 \mathrm{Aa}$ & $24.2 \pm 4.5 \mathrm{ABa}$ & $17.6 \pm 1.5 \mathrm{Ab}$ & $29.7 \pm 3.3 \mathrm{ABa}$ \\
\hline
\end{tabular}


Table 3. Continued.

\begin{tabular}{|c|c|c|c|c|c|c|c|}
\hline \multirow[b]{3}{*}{ Variable } & \multirow[b]{3}{*}{$n$} & \multicolumn{2}{|c|}{ Total richness } & \multicolumn{2}{|c|}{ Native richness } & \multicolumn{2}{|c|}{ Exotic richness } \\
\hline & & Pre & Post & Pre & Post & Pre & Post \\
\hline & & $\bar{X} \pm S E$ & $\bar{X} \pm S E$ & $\bar{X} \pm S E$ & $\bar{X} \pm S E$ & $\bar{X} \pm S E$ & $\bar{X} \pm S E$ \\
\hline \multicolumn{8}{|l|}{ Season } \\
\hline Spring & 23 & $14.9 \pm 0.4 \mathrm{Bb}$ & $19.8 \pm 0.9 \mathrm{Aa}$ & $8.3 \pm 0.2 \mathrm{Ab}$ & $11.3 \pm 0.6 \mathrm{Aa}$ & $6.7 \pm 0.2 \mathrm{Bb}$ & $8.6 \pm 0.3 \mathrm{Aa}$ \\
\hline Autumn & 22 & $17.2 \pm 0.5 \mathrm{Aa}$ & $16.5 \pm 0.8 \mathrm{Ba}$ & $9.0 \pm 0.3 \mathrm{Aa}$ & $8.5 \pm 0.4 \mathrm{Ba}$ & $8.2 \pm 0.3 \mathrm{Aa}$ & $8.0 \pm 0.5 \mathrm{Aa}$ \\
\hline \multicolumn{8}{|l|}{ Treatment } \\
\hline Control & 5 & $15.3 \pm 0.6 \mathrm{Aa}$ & $17.4 \pm 0.8 \mathrm{Ba}$ & $8.0 \pm 0.3 \mathrm{Ab}$ & $9.3 \pm 0.4 \mathrm{Ba}$ & $7.3 \pm 0.4 \mathrm{Aa}$ & $8.0 \pm 0.5 \mathrm{Ba}$ \\
\hline Cut & 10 & $15.7 \pm 0.8 \mathrm{Ab}$ & $21.3 \pm 1.2 \mathrm{Aa}$ & $8.5 \pm 0.4 \mathrm{Ab}$ & $11.6 \pm 1.0 \mathrm{Aa}$ & $7.2 \pm 0.5 \mathrm{Ab}$ & $9.7 \pm 0.5 \mathrm{Aa}$ \\
\hline Foliar & 10 & $16.1 \pm 0.7 \mathrm{Aa}$ & $13.4 \pm 0.9 \mathrm{Ca}$ & $8.8 \pm 0.3 \mathrm{Aa}$ & $7.6 \pm 0.5 \mathrm{Ca}$ & $7.3 \pm 0.5 \mathrm{Aa}$ & $5.8 \pm 0.5 \mathrm{Ca}$ \\
\hline Mechanical & 10 & $16.6 \pm 0.4 \mathrm{Ab}$ & $21.7 \pm 0.9 \mathrm{Aa}$ & $8.7 \pm 0.2 \mathrm{Ab}$ & $11.6 \pm 0.9 \mathrm{Aa}$ & $7.8 \pm 0.3 \mathrm{Ab}$ & $10.1 \pm 0.5 \mathrm{Aa}$ \\
\hline Stump & 10 & $16.2 \pm 1.3 \mathrm{Aa}$ & $16.8 \pm 0.9 \mathrm{Ba}$ & $8.8 \pm 0.7 \mathrm{Aa}$ & $9.2 \pm 0.5 \mathrm{Ba}$ & $7.4 \pm 0.7 \mathrm{Aa}$ & $7.6 \pm 0.4 \mathrm{Ba}$ \\
\hline
\end{tabular}


Table 3. Continued.

\begin{tabular}{|c|c|c|c|c|c|c|c|c|c|}
\hline \multirow[b]{3}{*}{ Variable } & \multirow[b]{3}{*}{$n$} & \multicolumn{2}{|c|}{ Diversity (H') } & \multicolumn{2}{|c|}{ Evenness (J') } & \multicolumn{2}{|c|}{ Mean $C$} & \multicolumn{2}{|c|}{$\overline{F Q I}$} \\
\hline & & Pre & Post & Pre & Post & Pre & Post & Pre & Post \\
\hline & & $\bar{X} \pm S E$ & $\bar{X} \pm S E$ & $\bar{X} \pm S E$ & $\bar{X} \pm S E$ & $\bar{X} \pm S E$ & $\bar{X} \pm S E$ & $\bar{X} \pm S E$ & $\bar{X} \pm S E$ \\
\hline \multicolumn{10}{|l|}{ Season } \\
\hline$\overline{\text { Spring }}$ & 23 & $2.06 \pm 0.04 \mathrm{Bb}$ & $2.51 \pm 0.05 \mathrm{Aa}$ & $0.77 \pm 0.01 \mathrm{Ab}$ & $0.85 \pm 0.01 \mathrm{Aa}$ & $3.53 \pm 0.05 \mathrm{Ab}$ & $3.81 \pm 0.03 \mathrm{Aa}$ & $10.1 \pm 0.2 \mathrm{Ab}$ & $12.6 \pm 0.3 \mathrm{Aa}$ \\
\hline Autumn & 22 & $2.25 \pm 0.04 \mathrm{Aa}$ & $2.09 \pm 0.09 \mathrm{Ba}$ & $0.80 \pm 0.01 \mathrm{Aa}$ & $0.75 \pm 0.03 \mathrm{Ba}$ & $3.54 \pm 0.05 \mathrm{Ab}$ & $3.85 \pm 0.04 \mathrm{Aa}$ & $10.5 \pm 0.2 \mathrm{Aa}$ & $11.0 \pm 0.2 \mathrm{Ba}$ \\
\hline \multicolumn{10}{|l|}{ Treatment } \\
\hline Control & 5 & $2.10 \pm 0.05 \mathrm{Ab}$ & $2.41 \pm 0.04 \mathrm{Ba}$ & $0.77 \pm 0.01 \mathrm{Ab}$ & $0.86 \pm 0.01 \mathrm{ABa}$ & $3.43 \pm 0.12 \mathrm{Ab}$ & $3.86 \pm 0.09 \mathrm{Aa}$ & $9.6 \pm 0.4 \mathrm{Ab}$ & $11.6 \pm 0.4 \mathrm{Ba}$ \\
\hline Cut & 10 & $2.12 \pm 0.06 \mathrm{Aa}$ & $2.40 \pm 0.14 \mathrm{Ba}$ & $0.78 \pm 0.02 \mathrm{Aa}$ & $0.79 \pm 0.04 \mathrm{BCa}$ & $3.56 \pm 0.08 \mathrm{Ab}$ & $3.89 \pm 0.04 \mathrm{Aa}$ & $10.2 \pm 0.3 \mathrm{Ab}$ & $13.1 \pm 0.6 \mathrm{Aa}$ \\
\hline Foliar & 10 & $2.13 \pm 0.08 \mathrm{Aa}$ & $2.05 \pm 0.10 \mathrm{Ca}$ & $0.78 \pm 0.03 \mathrm{Aa}$ & $0.80 \pm 0.02 \mathrm{BCa}$ & $3.51 \pm 0.05 \mathrm{Ab}$ & $3.82 \pm 0.05 \mathrm{Aa}$ & $10.3 \pm 0.6 \mathrm{Aa}$ & $10.3 \pm 0.3 \mathrm{Ca}$ \\
\hline Mechanical & 10 & $2.26 \pm 0.04 \mathrm{Ab}$ & $2.64 \pm 0.05 \mathrm{Aa}$ & $0.81 \pm 0.01 \mathrm{Ab}$ & $0.86 \pm 0.01 \mathrm{Aa}$ & $3.54 \pm 0.07 \mathrm{Aa}$ & $3.74 \pm 0.08 \mathrm{Aa}$ & $10.4 \pm 0.3 \mathrm{Ab}$ & $12.6 \pm 0.5 \mathrm{Aa}$ \\
\hline Stump & 10 & $2.12 \pm 0.09 \mathrm{Aa}$ & $2.07 \pm 0.14 \mathrm{Ca}$ & $0.77 \pm 0.02 \mathrm{Aa}$ & $0.73 \pm 0.04 \mathrm{Ca}$ & $3.58 \pm 0.06 \mathrm{Ab}$ & $3.84 \pm 0.05 \mathrm{Aa}$ & $10.5 \pm 0.4 \mathrm{Ab}$ & $11.5 \pm 0.3 \mathrm{Ba}$ \\
\hline
\end{tabular}

${ }^{1}$ Means in a column with different uppercase letters are significantly different $(p<0.05)$, based on Duncan's multiple range tests.

${ }^{2}$ Means in a row with different lowercase letters are significantly different $(p<0.05)$ between pre- and post-treatment based on paired t-tests. 


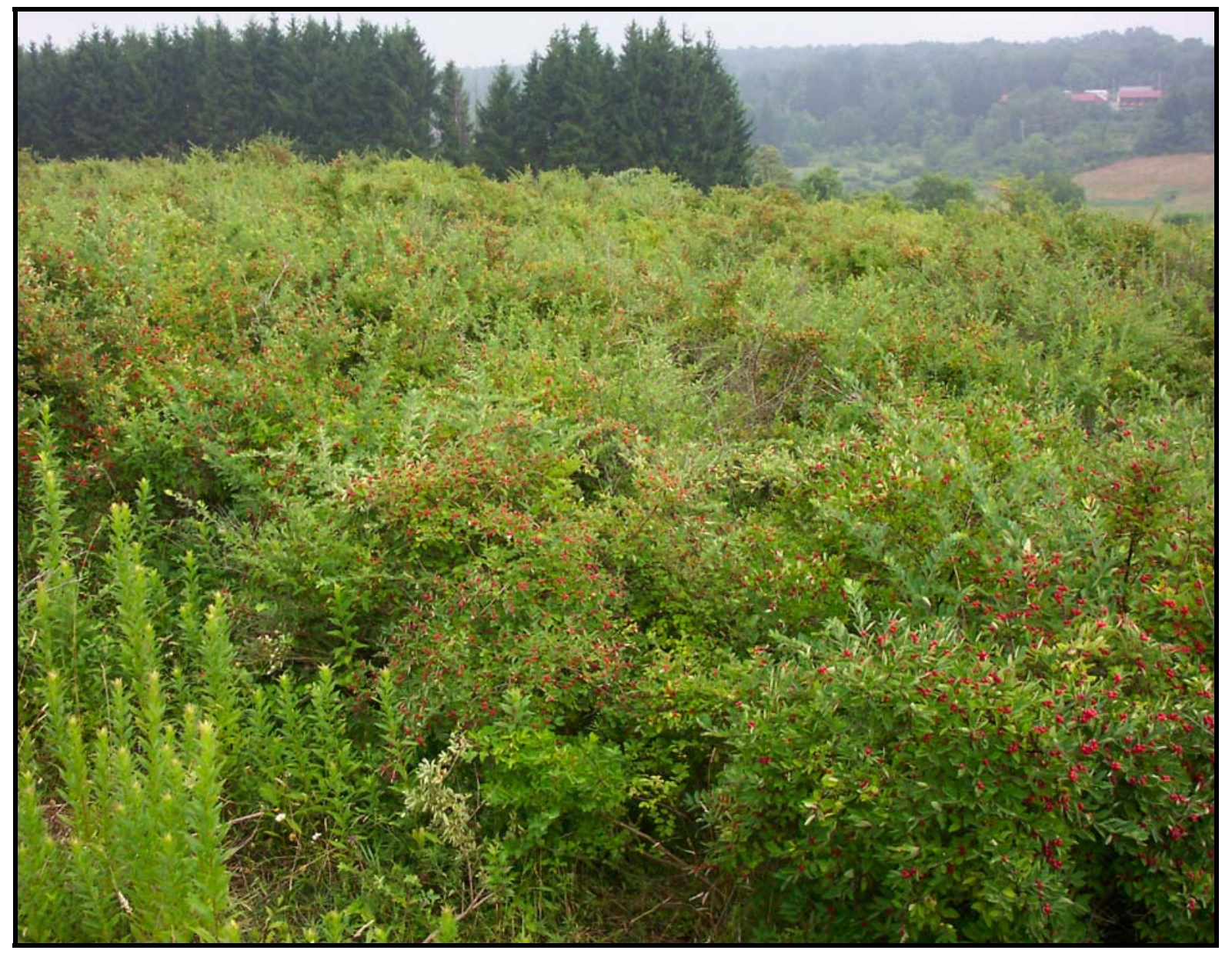

Figure 1. Our study site at Fort Necessity National Battlefield, Pennsylvania, U.S.A. was characterized by a dense monoculture of Lonicera morrowii (Morrow's honeysuckle); prior to treatment, we estimated that there were approximately 176,000 live stems/ha. 


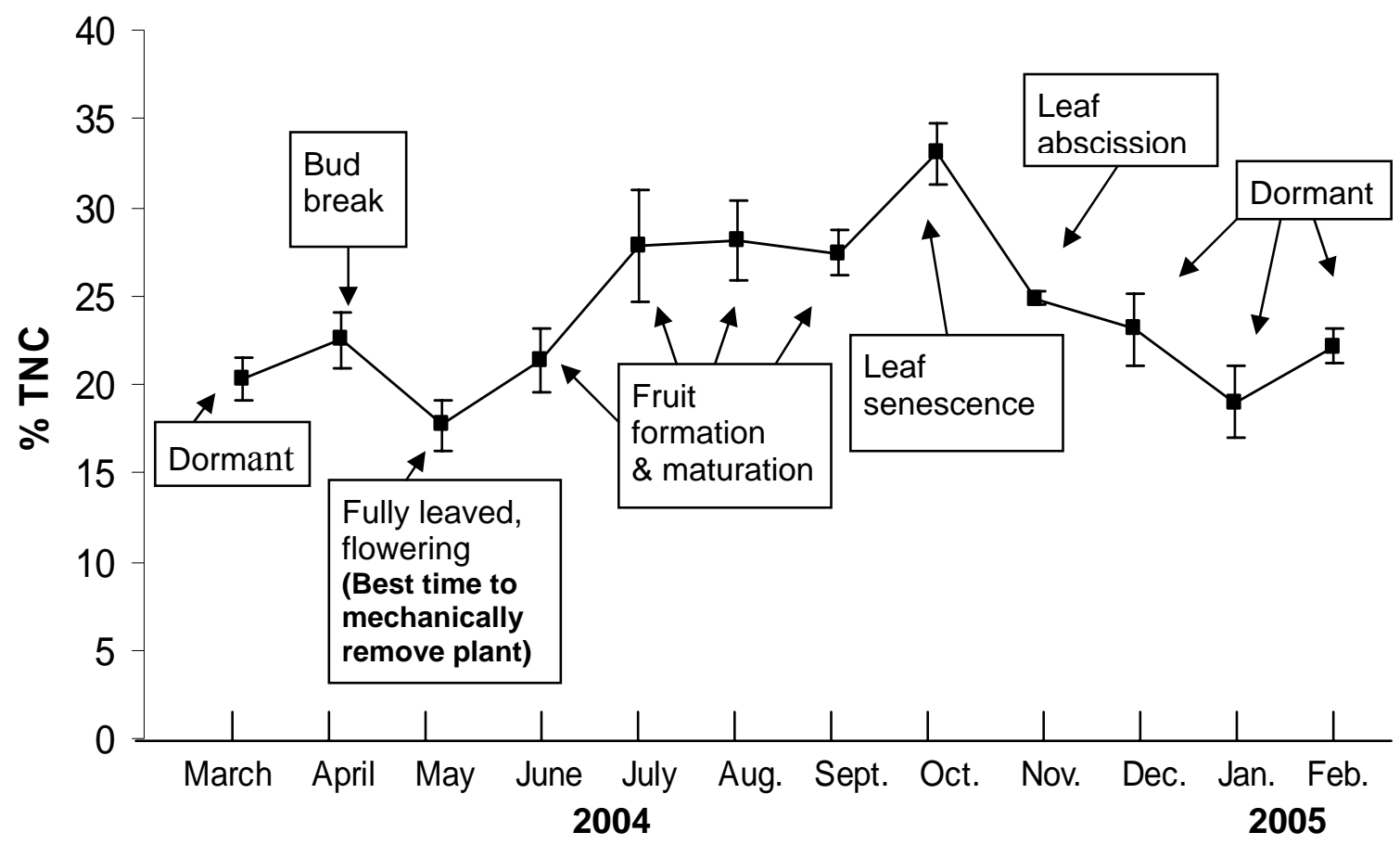

Figure 2. Total nonstructural carbohydrates for Morrow's honeysuckle were lowest in May at Fort Necessity National Battlefield, Pennsylvania, U.S.A., after the leaves were fully emerged; TNC levels were highest in October, as the leaves were beginning to senesce $(p<0.05)$. 

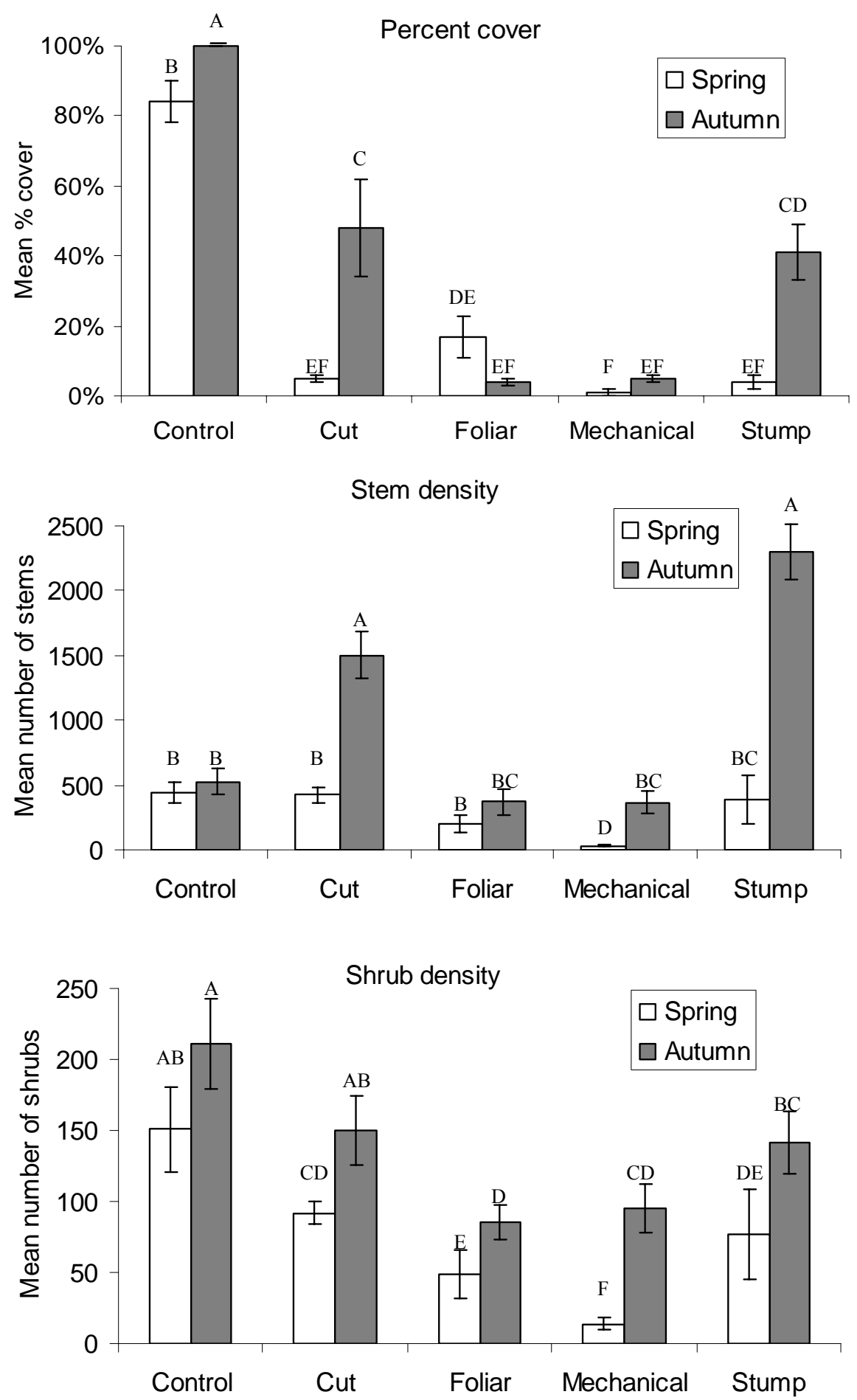

Figure 3. Mean $( \pm$ SE) post-treatment percent cover, stem density, and shrub density of Morrow's honeysuckle differed based on treatment and season at Fort Necessity National Battlefield, Pennsylvania. Means with different letters are significantly different, based on Duncan's multiple range tests $(p<0.05)$. 

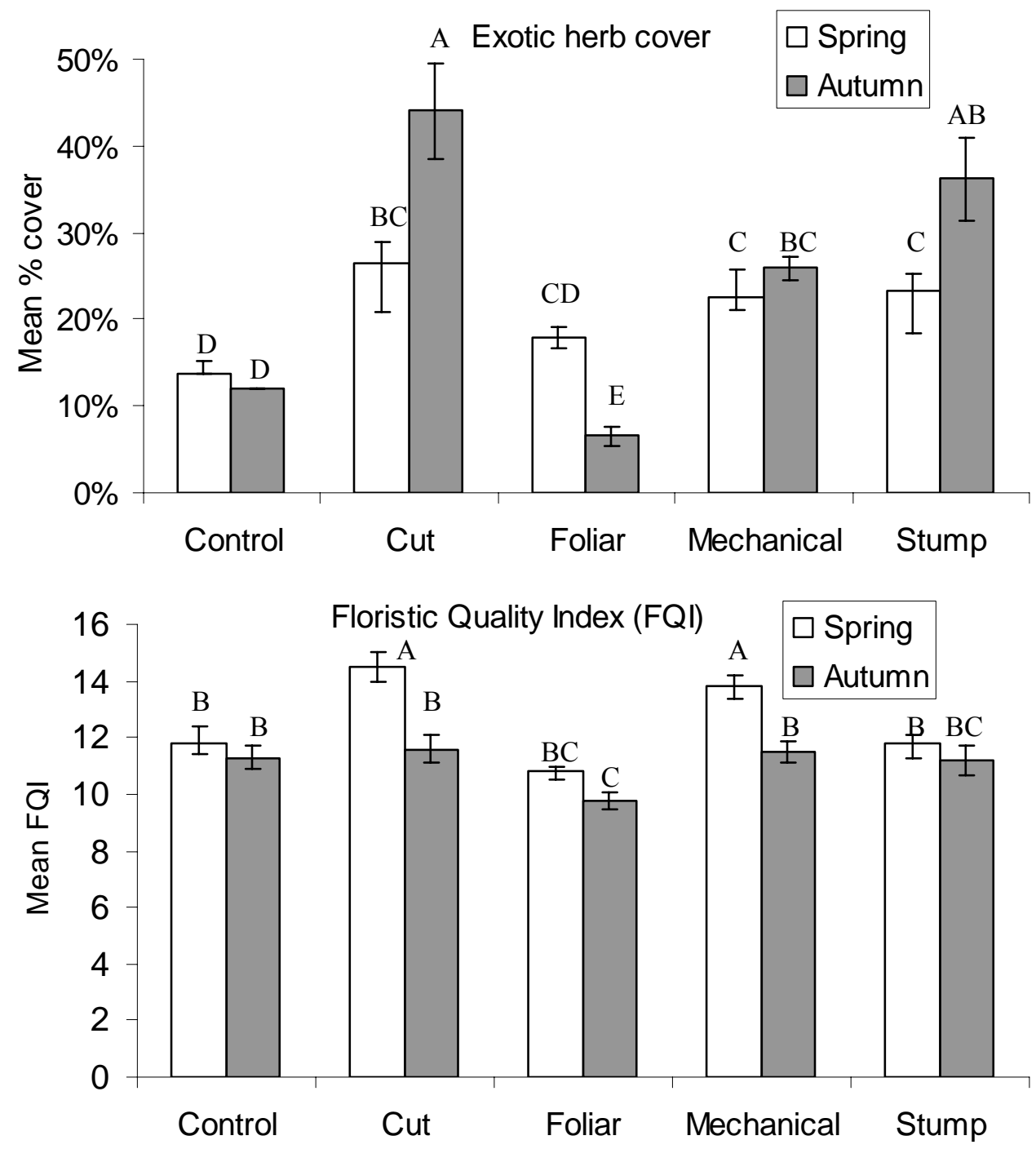

Figure 4. Mean ( \pm SE) exotic herbaceous plant cover and Floristic Quality Index (FQI) scores differed based on treatment and season at Fort Necessity National Battlefield, Pennsylvania. Means with different letters are significantly different, based on Duncan's multiple range tests $(p<0.05)$. 


\title{
CHAPTER 3
}

\section{EFFECTS OF AN EXOTIC INVASIVE SHRUB (LONICERA MORROWII) ON INVERTEBRATE ABUNDANCE, BIOMASS, AND RICHNESS}

\author{
JASON P. LOVE* AND JAMES T. ANDERSON ${ }^{*}$ \\ *Division of Forestry and Natural Resources, West Virginia University \\ Morgantown, WV, 26506, U.S.A.
}

\begin{abstract}
Exotic bush honeysuckles (Lonicera spp.) are becoming increasingly common in the eastern and mid-western United States, but little is known about their impacts on invertebrates. We used a modified leaf vacuum to sample invertebrates in the shrub strata of 3 shrub types: single Morrow's honeysuckle (L. morrowii) shrubs, single native southern arrowwood (Viburnum recognitum) shrubs, and dense thickets of Morrow's honeysuckle, within a degraded meadow in southwestern Pennsylvania, U.S.A. during July 2004, May 2005, and August 2005.

Additionally, we vacuumed invertebrates in the understory of the three shrub types, as well as in open plots with no shrub canopy. We measured several biotic and abiotic variables in the understory to develop a set of a priori models to determine factors driving patterns of invertebrate abundance and biomass. We also assessed the degree of herbivory on each of the
\end{abstract}

This chapter written in the style of Conservation Biology.

\footnotetext{
' Address correspondence to J. T. Anderson, email wetland@wvu.edu
} 
two species of shrubs. Within the shrub strata, invertebrate biomass was lower in southern arrowwood shrubs $(p<0.05)$, but there was no difference in invertebrate abundance or family richness. Invertebrate abundance and richness were lowest in August $(p<0.01)$, but there was no difference in biomass among the months. Invertebrate abundance, biomass, and family richness were lowest in the understory below dense thickets of Morrow's honeysuckle $(p<0.01)$. Overall, the percent cover of herbs was the proximate factor responsible for driving patterns of invertebrate abundance, though ultimately these patterns were being driven by shrub type. Abundance and biomass of larval leaf chewers were highest in the native shrub; Morrow's honeysuckle had a mean of $29.7 \mathrm{~cm}^{2}$ of leaf area consumed per $1 \mathrm{~m}^{2}$ of leaf area, while the native shrub had a mean of $284.3 \mathrm{~cm}^{2}$ of leaf area consumed. Our results suggest that areas dominated by the exotic shrub negatively impact invertebrate biomass, which may in turn affect organisms at higher trophic levels.

Key Words: Akaike's Information Criterion, enemy release hypothesis, exotic species, Fort Necessity National Battlefield, herbivory, introduced species, invertebrate abundance, invertebrate biomass, larval leaf chewers, Lonicera morrowii, Morrow’s honeysuckle, Pennsylvania, southern arrowwood, understory, Viburnum recognitum

\section{Introduction}

Invasions of exotic plants have increased in both frequency and scale (Mack \& Lonsdale 2001) so that today approximately 5,000 non-native plant species have become established in the United States alone (Pimentel et al. 2000). These invasions threaten biodiversity (e.g., Slobodchikoff \& Doyen 1977; Collier et al. 2002), alter ecosystem functions (Vitousek et al. 
1987), and impair local and global economies (Pimentel et al. 2000). Several studies describe the factors that produce successful plant invasions (e.g., Rejmánek \& Richardson 1996; Callaway \& Aschehoug 2000; Levine 2000). The enemy release hypothesis predicts that some exotic plants are successful invaders because they lack the specialist herbivores and diseases from their native habitat, thereby conferring a competitive advantage over native plants (e.g., Elton 1958; Lodge 1993; Tilman 1999). Measurements of herbivore loads on native and exotic plants typically find higher numbers of invertebrates on native plants (e.g., Strong et al. 1984; Schierenbeck et al. 1994; Yela \& Lawton 1997). However, no published studies have examined patterns of invertebrate biomass on native versus exotic plants (Tallamy 2004). Since invasive exotic plants are becoming increasingly widespread, their impacts on invertebrates could affect members of higher trophic levels, such as insectivorous mammals, herpetofauna, and terrestrial birds. For example, $96 \%$ of terrestrial birds in North America rear their young on invertebrate protein (Dicksinson 1999); subsequently, bird fitness is linked closely to the quality and quantity of their invertebrate food supplies (e.g., Burke \& Nol 1998; Marra et al. 1998; Zanette et al. 2000; Johnson \& Sherry 2001; but also see Folse 1982; Rodewald \& Vitz 2005).

Morrow's honeysuckle (Lonicera morrowii A. Gray) is an invasive exotic shrub that has spread throughout the northeastern and mid-Atlantic states (Batcher \& Stiles 2000). The shrub is one of a suite of closely-related bush honeysuckles originally introduced into North America for horticultural purposes, including Amur honeysuckle (L. maackii [Rupr.] Maxim), tatarian honeysuckle (L.tatarica L.), and Bell's honeysuckle (L. × bella Zabel) (Rehder 1940; Luken \& Thieret 1995). Several studies reveal that Morrow's honeysuckle and its close relatives negatively impact native herbaceous communities (Woods 1993; Collier et al. 2002; Hartman \& McCarthy 2004; Miller \& Gorchov 2004), seedling survival (Woods 1993; Gorchov \& Trisel 
2003; Hartman \& McCarthy 2004), spiders (Buddle et al. 2004), and vertebrates (Schmidt \& Whelan 1999; Borgmann \& Rodewald 2004; McEvoy \& Durtsche 2004). Additional studies describe mechanisms that may account for the shrub's success in invading foreign soils, including seed characteristics (Luken \& Goessling 1995), seed dispersal (Ingold \& Craycraft 1983; White \& Stiles 1992; Vellend 2002), plant phenology (Barnes \& Cottam 1974; Luken 1988; Harrington et al. 1989; Trisel \& Gorchov 1994; Chapter 2), and allelopathy (Barnes 1972; Trisel 1997).

Despite the relatively large body of literature on the impacts and mechanisms of bush honeysuckle invasions, no studies have addressed the impacts of the shrubs on invertebrate abundance, biomass, and diversity. The only studies that have examined invertebrate hosts of bush honeysuckles have focused their attention on the honeysuckle aphid (Hyadaphis tataricae, Homoptera: Aphididae), one of the few pests of bush honeysuckle (Mahr \& Dittl 1986; Herman \& Davidson 1997). Examining invertebrate abundance and diversity on Morrow's honeysuckle versus native shrubs might help in our understanding of how Morrow's honeysuckle is able to successfully invade foreign regions (i.e., the enemy release hypothesis). Concurrently, invertebrate abundance and diversity may provide a measuring stick on which future restoration efforts can be assessed (Parmenter et al. 1991; Chapin et al. 1992; Williams 1993; Webb et al. 2000; Ries et al. 2001).

Little information is available about how exotic plants impact ground-dwelling invertebrates (Buddle et al. 2004). Since exotic shrub honeysuckles reduce herb richness and abundance (e.g., Woods 1993; Collier et al. 2002), the shrubs are likely to affect invertebrates found in the understory, since the type and quantity of vegetation cover strongly influences the spatial distribution of invertebrates (e.g., Murdoch et al. 1972; Strong et al. 1984). However, the 
shrub also may affect abiotic parameters, such as soil moisture, soil temperature, amount of leaf litter, and leaf litter nutrient content. Soil moisture (e.g., Antvogel \& Bonn 2001; Wang et al. 2001; Hertl \& Brandenburg 2002) and soil temperature (Collett 2003) often drive patterns of invertebrate activity, abundance, and diversity. Leaf litter quantity (Badejo et al. 1998; Antvogel \& Bonn 2001; Lindsay \& French 2006) and quality (Badejo et al. 1998; Lindsay \& French 2006) may regulate ground-dwelling invertebrate composition and abundance as well.

Our objectives for this study were to (1) compare invertebrate abundance, biomass, and diversity among single Morrow's honeysuckle shrubs, single southern arrowwood shrubs (Viburnum recognitum Fern.), and dense thickets of Morrow's honeysuckle; (2) compare ground-dwelling invertebrate abundance, biomass, and diversity among the understory of single shrubs of Morrow's honeysuckle, single shrubs of southern arrowwood, dense thickets of Morrow's honeysuckle, and open plots with no overstory; (3) determine environmental variables that drive patterns of ground-dwelling invertebrate abundance, biomass, and diversity in the understory of the four understory types; and (4) assess differences in leaf herbivory between Morrow's honeysuckle and southern arrowwood.

\section{Methods}

\section{Study Site}

Our study took place at Fort Necessity National Battlefield, Fayette County, southwestern Pennsylvania, U.S.A. $\left(39^{\circ} 48^{\prime} 43^{\prime \prime} \mathrm{N}, 84^{\circ} 41^{\prime} 50^{\prime}\right.$ 'W). The park is situated in the Allegheny Mountain subregion of the Appalachian Plateau, an area also known as the southern Laurel Highlands. Our study site was a 14.6 ha meadow located in the park. The study site was formerly a mixed hardwood/conifer forest (Kelso 1994), but prior to 1933 the site was cleared for livestock grazing. After acquiring the land, the Park Service maintained the meadow by 
periodic mowing until the mid-1980s, at which time mowing ceased. It was thought that natural forest succession would eventually approximate historical vegetative conditions that existed during the 1754 battle at Fort Necessity, when George Washington and his troops unsuccessfully defended the fort against French and Indians in a battle that sparked the French-Indian War (C. Ranson, 2004, Fort Necessity National Battlefield, Farmington, PA, personal communication). However, Morrow's honeysuckle invaded the site, dominating the meadow $(67,920 \pm 4,480$ shrubs/ha), and preventing regeneration of native hardwoods (Chapter 2). The site is typical of many abandoned fields in the region that have been heavily invaded by Morrow's honeysuckle and other exotic bush honeysuckle species (personal observation). Other woody shrubs and saplings found in the meadow include red maple (Acer rubrum L.), southern arrowwood, waxyfruit hawthorne (Crataegus pruinosa [Wendl. f.] K. Koch), black cherry (Prunus serotina Ehrh.), and sweet crabapple (Malus coronaria [L.] P. Mill.). Common herbaceous species include sweet vernal grass (Anthoxanthum odoratum L.), wrinkleleaf goldenrod (Solidago rugosa P. Mill.), early goldenrod (S. juncea Ait.), northern dewberry (Rubus flagellaris Willd.), and orchard grass (Dactylis glomerata L.) (Chapter 2).

Low lying areas are characterized by Philo silt loams. These soils are deep, poor to moderately drained, medium textured, and were formed from acidic sediments derived from sandstone and shale. Upland sites within the meadow consist of Brinkerton and Armagh silt loams, Cavode silt loams, and Gilpin channery silt loams. These soils are moderately deep, moderate to well drained, medium-textured, and underlain by acidic shale and sandstone bedrock (Kopas 1973).

The climate is moderate continental. The average annual temperature is $9^{\circ} \mathrm{C}$, with a mean winter temperature of $-3^{\circ} \mathrm{C}$ and a mean summer temperature of $22^{\circ} \mathrm{C}$. Average annual 
precipitation is $119 \mathrm{~cm}$ (Fort Necessity National Battlefield. 1991. General Management Plan/Development Concept Plan/Interpretive Prospectus. Unpublished report of Fort Necessity National Battlefield, Farmington, PA).

\section{Invertebrate Sampling and Identification}

Prior to sampling, we selected 45 Morrow's honeysuckle and 45 southern arrowwood shrubs (both species are in the family Caprifoliaceae) that were $\geq 1.3 \mathrm{~m}$ in height and $>2 \mathrm{~m}$ from another woody shrub. Additionally, we selected 45 sites where dense thickets of Morrow's honeysuckle were growing. One-third of the shrubs from each of the three shrub types were randomly selected without replacement to determine shrubs to be sampled for each of three sampling periods: 7-11 July 2004, 26-31 May 2005, and 1-4 August 2005. Fifteen open plots containing no shrub cover were randomly selected and evenly paired with the three shrub types and sampling period (i.e., 5 open plots per shrub type and sampling period). To determine the location of the open plot, a cardinal direction was randomly selected; we followed this direction from the paired shrub until an open area was found that was $>3 \mathrm{~m}$ from another shrub.

We used a modified vacuum-blower (STIHL model SH 85 D Shredder Vacuum/Blower) to sample invertebrates (Osborne \& Allen 1999). This method was found to be superior to sweep netting in scrub/shrub habitat (Buffington \& Redak 1998). We collected invertebrates from two different strata: (1) on and within the shrubs, and (2) in the understory below the shrubs. We vacuumed shrubs for one minute in a steady up and down motion while slowly circling the shrub (Burger et al. 2003). The $1.3 \mathrm{~m}$ minimum shrub height requirement ensured that shrubs were large enough so that portions of the shrubs would not be resampled before time expired. We vacuumed $>0.5 \mathrm{~m}$ above the base of the shrub to avoid sampling invertebrates found on understory plants. When sampling invertebrates in the understory, we used a $23 \mathrm{~cm}$ 
diameter steel cylinder with sides $30.5 \mathrm{~cm}$ in height to delineate plots. For plots with a shrub overstory, the cylinder was placed midway between the base of the shrub and the outer perimeter of the shrub canopy. The area inside the cylinder was vacuumed for $30 \mathrm{sec}$. We sampled on relatively calm days with no rain and sampled after the dew had evaporated from the shrubs and herbs to make it easier to extract samples from the collection bag.

We placed the contents of each sample in a plastic bag and kept the samples on ice until the specimens could be placed in a freezer for storage. We hand-sorted invertebrates from debris under a dissecting microscope; invertebrates $\geq 2 \mathrm{~mm}$ were identified to the lowest taxonomic group (typically Family level) (Bland \& Jacques 1978; Borror et al. 1989) and measured to the nearest $0.1 \mathrm{~mm}$ using an ocular micrometer. We classified holometabolous insects as adults, larvae, or pupae. Ametabolous or hemimetabolous nymphs were classified as adults, since nymphs we encountered changed little as they matured, except in size and proportions. We used previously developed length-weight regression formulas to estimate dry mass of each specimen (Rogers et al. 1977; Schoener 1980; Collins 1992; Sample et al. 1993a; Hódar 1996; Benke et al. 1999; Sabo 2002). Because length-weight regression equations were not available for insect pupae, we excluded insect pupae from our biomass estimations (shrub pupae, $n=4$; understory pupae, $n=11$ ). After identification, we stored specimens in vials containing $70 \%$ ethanol.

\section{Factors Influencing Ground-dwelling Invertebrates}

We measured several biotic and abiotic variables at each understory plot after reviewing the literature for factors that influence ground-dwelling invertebrate loads. We identified and measured percent cover of herbaceous cover contained within each understory plot; nomenclature follows Kartesz (1999). Additionally, we noted whether plants were native or exotic. Because the number of invertebrates might be related to the amount of debris (leaf litter 
and live plant material) vacuumed into the collection bag while sampling, we weighed debris vacuumed from each plot (wet weight). After vacuuming each plot for invertebrates, the remaining leaf litter was hand-collected in the area delineated by the cylinder. This litter was later added to the leaf litter (minus the live plant material) collected while vacuuming. We dried the litter at $60^{\circ} \mathrm{C}$ for $72 \mathrm{hrs}$. and then weighed it to obtain dry mass. We then ground the litter in a Wiley mill fitted with a $1 \mathrm{~mm}$ sieve; percent nitrogen was determined using the automated Kjeldahl method (Hawk et al. 1947). Afterwards we used a spade to extract the soil within the plots to a depth of about $20 \mathrm{~cm}$; soil was thoroughly hand-mixed and a sub-sample was placed in a plastic bag. We sieved the soil and a $20 \mathrm{~g}$ sub-sample was weighed, dried at $60^{\circ} \mathrm{C}$ for $>48$

hrs., then weighed again to derive percent moisture content. We used a soil temperature probe to determine soil temperature at a depth of $4 \mathrm{~cm}$.

\section{Leaf Herbivory}

We collected one live $35-40 \mathrm{~cm}$ long branch located $1.3 \mathrm{~m}$ above the base of each of the single Morrow's honeysuckle and southern arrowwood shrubs sampled for invertebrates. Branches were placed in a plant press and the leaves were later analyzed for herbivory. We measured herbivory using three metrics. For the first metric, we placed leaves in two categories: (1) evidence of herbivory, and (2) no evidence of herbivory. Comparisons of herbivory between shrubs were based on the number of leaves with evidence of herbivory divided by the total number of leaves. For the second metric, we estimated the amount of leaf area consumed $\left(\mathrm{cm}^{2}\right)$ by invertebrate herbivores using software that determines leaf area based on the number of pixels within a polygon (ImageJ version 1.33u: Rasband 2005). From each branch, we randomly selected $\leq 15$ leaves that showed evidence of herbivory and $\leq 15$ leaves with no evidence of herbivory. We used a digital camera (Kodak Easyshare LS443, 4.0 megapixels) to photograph 
the leaves. We determined the total area and amount of herbivory of each leaf to the nearest 0.1 $\mathrm{mm}^{2}$ with ImageJ software. Leaf area loss was determined by dividing the total leaf area by the area of leaf loss. For the third metric, we examined all leaves and ranked the herbivory from $0-5$ based on visual estimation: $0=$ no herbivory; $1=1-5 \%$ herbivory; $2=6-25 \%$ herbivory; $3=26$ $50 \%$ herbivory; $4=51-75 \%$ herbivory, and $5=76-100 \%$ herbivory.

\section{Statistical Analyses \\ INVERTEBRATES}

When analyzing invertebrates, shrub species, and sample period (months) were the independent variables, while invertebrate abundance, biomass, and richness were the dependent variables. We used analysis of variance (ANOVA) (PROC GLM, SAS version 9.1; SAS Institute, Inc., Cary, NC, U.S.A.) to assess differences among shrub types, sample month, and to determine whether shrub type effects differed among sample months; Duncan's multiple range tests were used to compare differences between pairs. Invertebrate data were tested for normality and homogeneity of variance; assumptions were met using the following transformations: shrub invertebrates - eighth-root (abundance), quarter-root (biomass), and square-root (richness); understory invertebrates - square-root (abundance), quarter-root (biomass), and square-root (x+ 1) (richness).

\section{FACTORS INFLUENCING GROUND-DWELLING INVERTEBRATES}

We used information-theory to determine biotic and abiotic factors driving patterns of grounddwelling invertebrate abundance and biomass. We tested all dependent (invertebrate abundance and biomass) and independent variables (biotic and abiotic parameters) for normality and homogeneity of variance. We used the following transformations to meet assumptions prior to 
data analysis: square-root - invertebrate abundance (all months), invertebrate biomass (May), soil moisture (May), litter nitrogen (August), wet debris weight (August); quarter-root - invertebrate biomass (July and August), dry litter mass (all months), wet debris weight (May and July); and arcsine - percent native herbaceous cover (July and August). We ranked (PROC RANK, SAS version 9.1) soil temperature (May and July) and soil moisture (July) data; these data did not meet assumptions even after transformations. Data transformed into ranks are thought more likely to satisfy assumptions of the parametric model than would the original non-normal data (Conover \& Iman 1981). We reviewed relevant literature to specify sets of a priori candidate models for explaining ground-dwelling invertebrate abundance and biomass. We specified 7 models; a global model containing all 8 parameters and a subset of models representing potential influences of biotic and abiotic factors on ground-dwelling invertebrates (Tables 1, 2 \& 3; Appendix Ib \& IIb). Following model specification, we searched for redundant variables (Spearman's $r \geq 0.70$ ) to assess whether our models could be simplified; we found no significant correlations among the variables that we measured, so we retained 8 variables for inclusion in the models. We used linear regression (PROC GENMOD, SAS version 9.1) to analyze the model set for invertebrate abundance and biomass for each of the 3 months separately. We checked for overdispersion within our data sets by assessing the goodness-of-fit chi-square statistic of the global models divided by their degrees of freedom (i.e., estimated single variance inflation factor, $\hat{c}$ ), following the protocols of Burnham \& Anderson (2002). Invertebrate abundance in May was overdispersed $(\hat{c}=1.16, p<0.15)$, so we corrected for the overdispersed data using quasi-likelihood modifications (i.e., $\mathrm{QAIC}_{c}$ ) (Burnham \& Anderson 2002). No distinct lack of fit was found in the other data sets. 
Because the number of plots sampled $(n \leq 59)$ was small relative to the number of parameters $(K)$ (i.e., $n / K<40$ ), we used Akaike's Information Criterion corrected for small sample size $\left(\mathrm{AIC}_{c}\right.$ and $\left.\mathrm{QAIC}\right)$ for model selection (Burnham \& Anderson 2002). We used formulas presented in Burnham and Anderson (2002) to calculate $\mathrm{AIC}_{c}$ from our maximum likelihood methods. We ranked all models according to their $\mathrm{AIC}_{c}$ values; the best model (i.e., the most parsimonious) was the model with the smallest $\mathrm{AIC}_{c}$ value (Burnham \& Anderson 2002). We drew primary inference from models within 2 units of $\mathrm{AIC}_{c m i n}$, although models within 4-7 units may have some empirical support (Burnham \& Anderson 2002). We calculated Akaike weights $\left(w_{i}\right)$ to determine the strength of evidence in favor of each model and to estimate the relative importance of individual parameters (Burnham \& Anderson 2002).

\section{LEAF HERBIVORY}

When analyzing leaf herbivory data, shrub species and sample period (months) were the independent variables; percent of leaves with evidence of herbivory, leaf area consumed, and herbivory rank were the dependent variables. We used analysis of variance (ANOVA) (PROC GLM, SAS version 9.1) to assess differences of leaf herbivory between Morrow's honeysuckle and southern arrowwood, among months, and to determine shrub $\times$ month interaction effects; we used Duncan's multiple range tests to compare differences in herbivory between shrubs and among months. We tested all leaf herbivory data for normality and homogeneity of variance; data were not normal even after transformations, so we ranked the data (PROC RANK, SAS version 9.1) prior to analysis. Untransformed means and SEs are reported throughout the results. 


\section{Results}

\section{Invertebrates}

We collected 3,133 invertebrates from the shrub strata of lone Morrow's honeysuckle shrubs, lone southern arrowwood shrubs, and dense thickets of Morrow's honeysuckle. We identified 3 Classes, 16 Orders, and 129 Families of invertebrates (Appendix IIIb, IVb, \& Vb). Composition of invertebrates based on the most abundant families and the highest biomasses differed among the three shrub types (Table 4; Appendix IIIb, IVb, \& Vb). Total invertebrate biomass was lower in lone southern arrowwood shrubs $\left(F_{[2,126]}=3.24, p=0.043\right)$, but there was no difference in invertebrate abundance or richness among the three shrub types $\left(F_{[2,126]} \leq 0.94, p \geq 0.394\right)$. Invertebrate abundance and richness was lowest in August $\left(F_{[2,126]} \geq 11.37, p<0.001\right)$, but there was no difference in biomass among months $\left(\mathrm{F}_{[2,126]}=2.85, p=0.062\right)$. There were no shrub type $\times$ month interaction effects for invertebrate abundance, biomass, or richness $\left(F_{[4,126]} \leq 0.92\right.$, $p \geq 0.456$ ) (Table 5; Appendix VIb \& VIIb). Larval leaf chewers (i.e., Lepidoptera and Symphyta larvae) were lowest in dense thickets of Morrow's honeysuckle $(n=11$, biomass $=30.9 \mathrm{mg})$, followed by lone Morrow's honeysuckle shrubs $(n=16$, biomass $=107.9 \mathrm{mg})$ and lone southern arrowwood shrubs $(n=54$, biomass $=153.8 \mathrm{mg})$.

We collected 2,589 invertebrates from the understory below lone Morrow's honeysuckle shrubs, lone southern arrowwood shrubs, dense thickets of Morrow's honeysuckle, and in open plots with no overstory. We identified 6 Classes, 17 Orders, and 115 Families of invertebrates (Appendix VIIIb, IXb, Xb, \& XIb). Composition of invertebrates below the 4 shrub types differed based on abundance and biomass (Table 6; Appendix VIIIb, IXb, Xb, \& XIb). Invertebrate abundance, biomass, and richness were lowest in the understory below dense thickets of Morrow's honeysuckle $\left(F_{[3,168]} \geq 5.75, p<0.001\right)$. Invertebrate abundance and richness were lowest in August $\left(F_{[2,168]} \geq 13.84, p<0.001\right)$, but there was no difference in 
invertebrate biomass among the three months $\left(F_{[2,168]}=0.75, \mathrm{p}=0.476\right)$. We found a significant shrub type $\times$ month interaction for invertebrate abundance and richness $\left(F_{[6,168]} \geq 3.02\right.$, $p \leq 0.008$ ), but not for invertebrate biomass $\left(F_{[6,168]}=1.72, p=0.118\right)$ (Figure 1; Table 7; Appendix XIIb \& XIIIb).

\section{Factors Influencing Ground-dwelling Invertebrates}

For invertebrate abundance in May, the model "shrub" was the best-approximating model ( $w_{\mathrm{i}}=$ 0.99). The remaining models received no empirical support $\left(\Delta \mathrm{AIC}_{c} \geq 10.14, w_{\mathrm{i}} \leq 0.01\right)$ (Table 2$)$. For invertebrate abundance in July, the model "total herbs" $\left(w_{\mathrm{i}}=0.97\right)$ was the bestapproximating model, while the remaining 6 models had no empirical support $\left(\triangle \mathrm{AIC}_{c} \geq 8.25\right.$, $\left.w_{\mathrm{i}} \leq 0.02\right)$ (Table 2). In August, the model "total herbs" was the best-approximating model; the models "debris" $\left(\Delta \mathrm{AIC}_{c}=1.04, w_{\mathrm{i}}=0.24\right)$ and "native herbs" $\left(\Delta \mathrm{AIC}_{c}=1.33, w_{\mathrm{i}}=0.21\right)$ also received strong empirical support, while the models "soil" $\left(\Delta \mathrm{AIC}_{c}=3.33, w_{\mathrm{i}}=0.08\right)$ and "litter" $\left(\Delta \mathrm{AIC}_{c}=3.84, w_{\mathrm{i}}=0.06\right)$ received limited support (Table 2$)$.

For invertebrate biomass in May, the model "total herbs" $\left(w_{\mathrm{i}}=0.47\right)$ was the best approximating model, though the models "debris" $\left(\Delta \mathrm{AIC}_{c}=1.85, w_{\mathrm{i}}=0.19\right)$, "native herbs" $\left(\Delta \mathrm{AIC}_{c}=2.51, w_{\mathrm{i}}=0.13\right)$, and "litter" $\left(\Delta \mathrm{AIC}_{c}=3.09, w_{\mathrm{i}}=0.10\right)$ also had strong empirical support. The remaining models had little to no support $\left(\Delta \mathrm{AIC}_{c} \geq 4.37, w_{\mathrm{i}} \leq 0.05\right)$ (Table 3$)$. In July, the model "total herbs" $\left(w_{\mathrm{i}}=0.81\right)$ was the best-approximating model to determine patterns of invertebrate biomass, although the model "debris" $\left(\Delta \mathrm{AIC}_{c}=3.56, w_{\mathrm{i}}=0.14\right)$ also had some empirical support; the remaining models received no empirical support $\left(\Delta \mathrm{AIC}_{c} \geq 7.10, w_{\mathrm{i}} \leq 0.02\right)$ (Table 3). For invertebrate biomass in August, the model "shrub" $\left(w_{\mathrm{i}}=0.47\right)$ was the bestapproximating model, though the models "native herbs" $\left(\Delta \mathrm{AIC}_{c}=2.00, w_{\mathrm{i}}=0.17\right)$, "debris" $\left(\Delta \mathrm{AIC}_{c}=2.52, w_{\mathrm{i}}=0.13\right)$, and "total herbs" $\left(\Delta \mathrm{AIC}_{c}=2.54, w_{\mathrm{i}}=0.13\right)$ also had strong empirical 
support. The remaining models had little or no empirical support $\left(\Delta \mathrm{AIC}_{c} \geq 4.37, w_{\mathrm{i}} \leq 0.05\right)$.

Overall, there was a strong relationship among both invertebrate abundance and biomass to total herbaceous cover and shrub type relative to other biotic and abiotic factors (Figure 2; Table 8; Appendix XIVb \& XVb). Moreover, the proportion of native herbs was consistently depressed under dense thickets of Morrow's honeysuckle relative to the other shrub types (Table 8; Appendix XIVb \& XVb).

\section{Leaf Herbivory}

Over the course of the three sample periods, we analyzed and assigned ranks to 4,465 leaves of Morrow's honeysuckle and 1,121 leaves of southern arrowwood. Additionally, we photographed 181 leaves of Morrow's honeysuckle and 308 leaves of southern arrowwood that showed signs of herbivory; 615 leaves of Morrow's honeysuckle and 91 leaves of southern arrowwood were photographed that did not shows signs of leaf herbivory. Mean $( \pm \mathrm{SE})$ total leaf area of Morrow's honeysuckle with leaf herbivory was $3.38 \pm 0.17 \mathrm{~cm}^{2}$, while mean leaf area of leaves that were entire was $3.13 \pm 0.07 \mathrm{~cm}^{2}$. Mean $( \pm \mathrm{SE})$ total leaf area of southern arrowwood leaves with signs of herbivory was $9.77 \pm 0.31 \mathrm{~cm}^{2}$, while mean area of leaves without signs of herbivory was $7.13 \pm 0.48 \mathrm{~cm}^{2}$.

Southern arrowwood was significantly greater than Morrow's honeysuckle in percent of leaves with evidence of herbivory and leaf $\operatorname{rank}\left(F_{[1,84]} \geq 139.30, p<0.001\right)$, as well as leaf area consumed $\left(F_{[1,77]}=18.31, p<0.001\right)$. Overall, southern arrowwood had $284.3 \mathrm{~cm}^{2}$ of leaf area consumed per $1 \mathrm{~m}^{2}$ of leaf area, while Morrow's honeysuckle had $29.7 \mathrm{~cm}^{2}$ of leaf area consumed per $1 \mathrm{~m}^{2}$ of leaf area. Herbivory metrics in May were consistently lower relative to metrics in July and August. There were significant differences among months for percent of leaves with evidence of herbivory and leaf $\operatorname{rank}\left(F_{[2,84]} \geq 49.61, p<0.001\right)$, as well as leaf area 
consumed and percent of leaf consumed $\left(F_{[2,77]}=5.40, p=0.006\right)$. Moreover, there were significant shrub $\times$ month interaction effects for percent of leaves with evidence of herbivory and leaf rank $\left(F_{[2,84]} \geq 8.89, p<0.001\right)$ (Figure 3$)$, though there were no significant differences in mean leaf area consumed $\left(F_{[2,77]}=2.90, p=0.061\right)($ Table 9; Appendix XVIb \& XVIIb).

\section{Discussion}

\section{Invertebrates}

While several studies have examined invertebrate abundance on exotic versus native plants (e.g., Strong et al. 1984; Schierenbeck et al. 1994; Yela \& Lawton 1997), this is the first study we are aware of that examined the effects of exotic plants on invertebrate biomass (Tallamy 2004). Since invertebrate biomass is closely linked to the energetic value of an invertebrate food item (Krebs \& McCleery 1984; Karasov 1990; Johnson 2000), our findings could have implications for organisms at higher trophic levels, such as songbirds. For instance, we found that within the shrub strata, the native shrub contained lower overall invertebrate biomass than either dense thickets or single shrubs of exotic Morrow's honeysuckle (though there was no such trend when mean biomass was divided by shrub type and month). However, the native shrub contained 5 times more larval leaf chewer biomass than found in thickets of the exotic shrub and 1.5 times more than found on single Morrow's honeysuckle shrubs. Lower levels of larval leaf chewers could possibly increase foraging distance and time for some species of songbirds (Sample et al. 1993b), particularly during the nesting season when invertebrate protein, especially from larval leaf chewers, makes up a large portion of the diet of nestlings (e.g., Nolan et al. 1999). For example, Prairie Warblers (Dendroica discolor) were common nesting songbirds within our study site (Love, J. P., J. A. Edalgo, and J. T. Anderson. 2006. Management plan for a degraded meadow infested with Morrow's honeysuckle. Unpublished report submitted to Fort Necessity 
National Battlefield, Farmington, PA) and primarily feed their young larval leaf chewers such as caterpillars (Nolan et al. 1999), which are higher in nutrients than most other groups of invertebrates (Schowalter et al. 1981). Other studies reveal that birds nesting in Amur honeysuckle have lower rates of nest success than nests found in native shrubs and trees; lower nest height, greater shrub volume, lack of sharp thorns, and branch architecture that facilitate movement of predators are thought to contribute to higher rates of nest predation in these exotic shrubs relative to native shrubs and trees (Schmidt \& Whelan 1999; Borgmann \& Rodewald 2004). If these nests are in a matrix of exotic shrubs which produce few larval leaf chewers, then the extra time and effort spent foraging for preferred prey could also be a contributing factor leading to increased rates of nest predation. Clearly more research is needed to ascertain whether there is a link between reduced biomass of important invertebrate prey items on exotic bush honeysuckles and bird foraging behavior and subsequent nest success.

Invertebrate composition within the shrub strata differed among the three shrub types. Ants (Hymenoptera: Formicidae) were 5 times more abundant on southern arrowwood relative to lone shrubs of Morrow's honeysuckle and nearly 14 times more abundant relative to dense thickets of the exotic shrub. We attribute this pattern to large numbers of aphids (Homoptera: Aphididae) feeding on the native shrub. Ants feed on honeydew produced by aphids and protect aphid colonies from predators and sooty mold contamination (Way 1963; Petal 1978); this strong correlation between aphid and ant abundance has been observed before (e.g., Schowalter et al. 1981). Moreover, we also observed ants feeding directly from sugar exudates arising from immature berries of southern arrowwood, even in the absence of aphids. Ladybugs (Coleoptera: Coccinellidae) had the greatest biomass on southern arrowwood, where they were the top invertebrate in terms of biomass. We also attribute this pattern to the presence of aphids feeding 
on southern arrowwood; the beetles were observed feeding on the aphids, a favorite prey item for ladybugs (e.g., Bland \& Jacques 1978).

Invertebrate biomass was consistently reduced in the understory below dense thickets of Morrow's honeysuckle over all months. In a Kentucky forest, northern slimy salamanders (Plethodon glutinosus) and green frogs (Rana clamitans) found in areas with a dense cover of Amur honeysuckle had lower body mass compared to non-invaded areas, suggesting that the shrub might be reducing the availability of prey items, although no quantitative data on invertebrate availability was obtained (McEvoy \& Durtsche 2004). Invertebrate richness also was significantly lower under dense thickets of Morrow's honeysuckle, a trend also found with spiders found in the understory of hedges dominated by Amur honeysuckle (Buddle et al. 2004).

\section{Factors Influencing Invertebrate Patterns}

Overall, patterns of invertebrate abundance and biomass in the understory were driven by percent cover of herbs, which in turn was ultimately influenced by the type of shrub overstory. Reduced herbaceous cover in areas dominated by Amur honeysuckle was thought to be the proximate factor responsible for depressing spider richness (Buddle et al. 2004) and amphibian condition and diversity (McEvoy \& Durtsche 2004). Other studies also have documented the positive correlation of understory herbaceous cover and invertebrate abundance (e.g., Webb et al. 1984; Hendrix et al. 1988; Samways et al. 1996; Haddad et al. 2001; Jamison et al. 2002; Allombert et al. 2005; but also see Steenkamp \& Chown 1996). The reduced abundance, biomass, and richness under dense thickets of Morrow's honeysuckle is not surprising given the numerous studies showing the shrubs' impact on herbaceous diversity and cover (e.g., Woods 1993; Collier et al. 2002; Hartman \& McCarthy 2004). It is interesting to note that the proportion of native herbaceous species was reduced under dense thickets of Morrow's 
honeysuckle relative to the other shrub types; future studies should assess whether this trend occurs with other bush honeysuckle species.

Our study revealed that patterns of invertebrate abundance are not necessarily correlated with invertebrate biomass. For instance, invertebrates captured in the shrub strata of southern arrowwood were greater in abundance than the other two shrub types, but had significantly less biomass compared to the other shrub types. Moreover, there were few invertebrate families that were among both the five most abundant invertebrate groups and five heaviest groups in terms of total biomass. We caution researchers that correlating invertebrate abundance with biomass may be misleading.

One limitation of our study is that we did not identify invertebrates to species. There is a possibility that exotic invertebrates may have contributed a significant portion of the overall invertebrate abundance, biomass, and richness and may have skewed our expected results (i.e., enemy release hypothesis - significantly greater abundance, biomass, and richness of invertebrates found in the shrub strata of the native shrub relative to the exotic shrub). For instance, European honey bees (Apis mellifera, Hymenoptera: Apidae) were sampled during May on Morrow's honeysuckle when the shrubs were flowering. We only captured 3 of these insects on single shrubs of Morrow's honeysuckle, but because of their large size relative to other invertebrates, they had the second most total mass of invertebrate groups found on this shrub type. We also captured 1 Japanese beetle (Popillia japonica, Coleoptera: Scarabaeidae) on southern arrowwood. It is possible that more species of exotic invertebrates were sampled. For example, in a simultaneous experiment at our study site researching patterns of earthworm abundance, biomass, and richness, only 4 species of earthworms were sampled and all 4 species were exotic (Edalgo 2005). However, based on the limited herbivory on Morrow's honeysuckle 
relative to southern arrowwood, we believe that if any exotic phytophagous invertebrates were present that fed on Morrow's honeysuckle, we would have observed more leaf damage.

It is also possible that native Lonicera-specific herbivores may have been feeding on Morrow's honeysuckle. Related species of plants often present similar chemical cues that attract herbivores (e.g., Ehrlich \& Raven 1964). Introduced plants that are closely related to native plants often draw the same suite of herbivores and have similar rates of herbivory (e.g., Connor et al. 1980; Agrawal \& Kotanen 2003). However, native bush honeysuckles are rare in Pennsylvania, making it doubtful that a host shift to Morrow's honeysuckle has occurred. Three of the four native species, hairy honeysuckle (L. hirsuta Eat.), swamp fly honeysuckle ( $L$. oblongifolia (Goldie) Hook.), and mountain fly honeysuckle (L. villosa (Michx.) J. A. Schultes) have a state heritage rank of S1 ( $<5$ populations recorded in the state) (Rhoads \& Klein 1993; NatureServe 2005). While not ranked in Pennsylvania, a fourth native honeysuckle, limber honeysuckle (L. dioica L.) has a rank of S3 (21-100 occurrences in the state) in neighboring West Virginia and is infrequently encountered (NatureServe 2005; W. Grafton 2005, West Virginia University, Morgantown, personal communication). Moreover, no native bush honeysuckles have been recorded at Fort Necessity National Battlefield and the relatively low rates of herbivory that we documented support our belief that few, if any, native Loniceraspecific hosts feed on Morrow's honeysuckle.

Because the native shrubs that we sampled occurred in a landscape matrix dominated by the exotic Morrow's honeysuckle, there is a possibility that the exotic shrubs impeded herbivores from moving to these patches of native shrubs (i.e., fragmentation), thereby reducing the overall abundance, biomass, and richness of invertebrates found on the native shrubs. For example, a planthopper (Homoptera: Cicadellidae) and its specialist parasitoid (Hymenoptera: Mymaridae) 
were $50 \%$ lower in native patches of the host plant that were embedded in a matrix of exotic grass compared to a matrix dominated by the native host plant (Cronin \& Haynes 2004). Other studies reveal that the composition of the habitat between host-patch patches can significantly affect interpatch movement rates of herbivores (e.g., Roland et al. 2000; Rickets 2001; Haynes \& Cronin 2003). Our results may have differed if the native shrubs we sampled were located in native vegetative communities, though we can only speculate since we did not measure landscape effects.

\section{Leaf Herbivory}

Leaf herbivory was nearly 10 times more on the native southern arrowwood than on Morrow's honeysuckle. Trisel and Gorchov (1994) examined herbarium specimens of Amur honeysuckle and found less leaf damage compared to native shrubs, suggesting that the shrub may be relatively free from herbivores and/or pathogens; the lack of herbivores and pathogens may be partly responsible for its success in invading foreign soils. Branches that were newly formed on Morrow's honeysuckle typically had larger leaves than older branches (personal observation). Since insects often prefer newer, more palatable leaves, (Strong et al. 1984), we believe the larger size of leaves on younger branches explains the reason why larger leaves were more likely to have herbivory. On southern arrowwood, we believe the larger leaves were older and thereby had a greater chance of being exploited by herbivores. In our samples, we observed shrubs affected by the fungus Insolibasidium deformans (Auriculariaceae) (fungus id confirmed by W. MacDonald 2004, West Virginia University, Morgantown), a blight specific to Lonicera that causes a crinkling and browning of the leaves (Sinclair et al. 1987). However, we did not quantitatively measure this disease and it did not seem to have a deleterious impact on the shrub. 
Overall our results suggest that the enemy release hypothesis is at least partly responsible for the success of Morrow's honeysuckle invading and persisting at our study site.

\section{Conclusion}

Many land managers believe that bush honeysuckles, including Morrow's honeysuckle, create sufficient habitat for songbirds and game species (e.g., VanDruff et al. 1996). Moreover, the abundant, conspicuous red berries are often cited as being beneficial for wildlife, particularly songbirds (Ingold \& Craycraft 1983; Whelan \& Dilger 1992; Rodewald \& Brittingham 2004). However, in light of recent studies showing increased rates of nest predation in bush honeysuckles (Schmidt \& Whelan 1999; Borgmann \& Rodewald 2004) and evidence of deleterious effects of the shrubs on amphibians (McEvoy \& Durtsche 2004), coupled with our findings of decreased larval leaf chewer biomass in the shrub strata of the exotic shrub and significantly decreased invertebrate biomass under dense thickets of the shrub, we believe that habitats dominated by Morrow's honeysuckle may be at best, marginal habitat, and at worst, ecological traps.

\section{Acknowledgments}

Funding for this project was provided by the National Park Service and Fort Necessity National Battlefield. We thank the staff of Fort Necessity National Battlefield, especially C. Ranson, for her support and advice throughout the project. For field and lab assistance, we thank J. Edalgo, J. E. Love, M. Hepner, B. Crokus, J. Alexander, V. Wells, E. Ralph, D. Ralph, A. Strippel, and A. Williams. V. Kondo, L. Butler, R. Utz, and D. Hartman went out of their way to help identify problematic invertebrate specimens. W. Grafton aided in the identification of plant specimens. 
L. Butler gave helpful advice on the art of invertebrate sampling. A. B. Billings provided statistical advice. J. McGraw and C. Ranson graciously reviewed earlier drafts of this manuscript. This is scientific article XXXX of the West Virginia University Agricultural and Forestry Experiment Station.

\section{Literature Cited}

Agrawal, A. A., and P. M. Kotanen. 2003. Herbivores and the success of exotic plants: a phylogenetically controlled experiment. Ecology Letters 6:712-715.

Allombert, S., S. Stockton, and J. Martin. 2005. A natural experiment on the impact of overabundant deer on forest invertebrates. Conservation Biology 19:1917-1929.

Antvogel, H., and A. Bonn. 2001. Environmental parameters and microspatial distribution of insects: a case study of carabids in an alluvial forest. Ecography 24:470-482.

Badejo, M. A., T. I. Nathaniel, and G. Tian. 1998. Abundance of springtails (Collembola) under four agroforestry tree species with contrasting litter quality. Biology and Fertility of Soils 27:15-20.

Barnes, W. J. 1972. The autoecology of the Lonicera $\times$ bella complex. Ph.D. Dissertation. University of Wisconsin, Madison.

Barnes, W. J., and G. Cottam. 1974. Some autoecological studies of the Lonicera $\times$ bella complex. Ecology 55:40-50.

Batcher, M. S., and S. A. Stiles. 2000. Element stewardship abstract for Lonicera maackii (Rupr.) Maxim (Amur honeysuckle), Lonicera morrowii A. Gray (Morrow’s honeysuckle), Lonicera tatarica L. (tatarian honeysuckle), Lonicera $\times$ bella Zabel (Bell's 
honeysuckle). The Nature Conservancy, Arlington, Virginia. Available from http://tncweeds.ucdavis.edu/esadocs/documnts/loni_sp.pdf (accessed October 2005).

Benke, A. C., A. D. Huryn, L. A. Smock, and J. B. Wallace. 1999. Length-mass relationships for freshwater macroinvertebrates in North America with particular reference to the southeastern United States. Journal of the North American Benthological Society 18:308343.

Bland, R. G., and H. E. Jacques. 1978. How to know the insects. $3^{\text {rd }}$ edition. WCB/McGraw-Hill, Dubuque, Iowa.

Borgmann, K. L., and A. D. Rodewald. 2004. Nest predation in an urbanizing landscape: the role of exotic shrubs. Ecological Applications 14:1757-1765.

Borror, D. J., C. A. Triplehorn, and N. F. Johnson. 1989. An introduction to the study of insects. $6^{\text {th }}$ edition. Thomson Learning, Inc., Victoria, South Melbourne, Australia.

Buddle, C. M., S. Higgins, and A. L. Rypstra. 2004. Ground-dwelling spider assemblages inhabiting riparian forests and hedgerows in an agricultural landscape. American Midland Naturalist 151:15-26.

Buffington, M. L., and R. A. Redak. 1998. A comparison of vacuum sampling versus sweepnetting for arthropod biodiversity measurements in California coastal sage scrub. Journal of Insect Conservation 2:99-106.

Burger, J. C., R. A. Redak, E. B. Allen, J. T. Rotenberry, and M. F. Allen. 2003. Restoring arthropod communities in coastal sage scrub. Conservation Biology 17:460-467.

Burke, D. M., and E. Nol. 1998. Influence of food abundance, nest-site habitat, and forest fragmentation on breeding Ovenbirds. Auk 115:96-104. 
Burnham, K. P., and D. R. Anderson. 2002. Model selection and multimodel inference: a practical information-theoretic approach. $2^{\text {nd }}$ edition. Springer-Verlag, New York, New York.

Callaway, R. M., and E. T. Aschehoug. 2000. Invasive plants versus their new and old neighbors: a mechanism for exotic invasion. Science 290:521-523.

Chapin, F. S., E. D. Schulze, and H. A. Mooney. 1992. Biodiversity and ecosystem process. Trends in Ecology and Evolution 7:432-433.

Collett, N. 2003. Short and long-term effects of prescribed fires in autumn and spring on surface active arthopods in sclerophyll eucalypt forests of Victoria. Forest Ecology and Management 182:117-138.

Collier, M. H., J. L. Vankat, and M. R. Hughes. 2002. Diminished plant richness and abundance below Lonicera maackii, an invasive shrub. American Midland Naturalist 147:60-71.

Collins, P. T. 1992. Length-biomass relationships for terrestrial Gastropoda and Oligochaeta. American Midland Naturalist 128:404-406.

Conover, W. J., and R. L. Iman. 1981. Rank transformation as a bridge between parametric and nonparametric statistics. American Statistician 35:124-133.

Connor, E. F., S. H. Faeth, D. Simberloff, and P. A. Opler. 1980. Taxonomic isolation and the accumulation of herbivorous insects: a comparison of introduced and native trees. Ecological Entomology 5:205-211.

Cronin, J. T., and K. J. Haynes. 2004. An invasive plant promotes unstable host-parasitoid patch dynamics. Ecology 85:2772-2782.

Dickinson, M. B. 1999. Field guide to the birds of North America. $3^{\text {rd }}$ edition. National Geographic Society, Washington D.C. 
Edalgo, J. A. 2005. Implications for the small mammal and earthworm communities in a degraded ecosystem. MS Thesis. West Virginia University, Morgantown. Available from https://eidr.wvu.edu/etd/documentdata.eTD?documentid=4326 (accessed February 2006).

Ehrlich, P. R., and P. H. Raven. 1964. Butterflies and plants: a study in coevolution. Evolution 18:568-608.

Elton, C. S. 1958. The ecology of invasion by plants and animals. Chapman and Hall, London, United Kingdom.

Folse, L. J., Jr. 1982. An analysis of avifauna-resource relationships on the Serengeti plains. Ecological Monographs 52:111-127.

Gorchov, D. L., and D. E. Trisel. 2003. Competitive effects of the invasive shrub, Lonicera maackii (Rupr.) Herder (Caprifoliaceae), on the growth and survival of native tree seedlings. Plant Ecology 166:13-24.

Haddad, N. M., D. Tilman, J. Haarstad, M. Ritchie, and J. M. H. Knops. 2001. Contrasting effects of plant richness and composition on insect communities: a field experiment. American Naturalist 58:17-35.

Harrington, R. A., B. J. Brown, and P. B. Reich. 1989. Ecophysiology of exotic and native shrubs in southern Wisconsin: relationship of leaf characteristics, resource availability, and phenology to seasonal patterns of carbon gain. Oecologia 80:356-367.

Hartman, K. M., and B. C. McCarthy. 2004. Restoration of a forest understory after the removal of an invasive shrub, Amur honeysuckle (Lonicera maackii). Restoration Ecology 12:154-165.

Hawk, P. B., B. L. Oser, and W. H. Summerson. 1947. Practical physiological chemistry. $12^{\text {th }}$ edition. Blakiston, Toronto, Canada. 
Haynes, K. J., and J. T. Cronin. 2003. Matrix composition affects the spatial ecology of a prairie planthopper. Ecology 84:2856-2866.

Hendrix, S. D., V. K. Brown, and H. Dingle. 1988. Arthropod guild structure during early old field succession in a new and old world site. Journal of Animal Ecology 57:1053-1065.

Herman, D. E., and C. G. Davidson. 1997. Evaluation of Lonicera taxa for honeysuckle aphid susceptibility, winter hardiness and use. Journal of Environmental Horticulture 15:177182.

Hertl, P. T., and R. L. Brandenburg. 2002. Effect of soil moisture and time of year on mole cricket (Orthoptera: Gryllotalpidae) surface tunneling. Environmental Entomology 31:476-481.

Hódar, J. A. 1996. The use of regression equations for estimation of arthropod biomass in ecological studies. Acta Oecologica 17:421-433.

Ingold, J. L., and M. J. Craycraft. 1983. Avian frugivory on honeysuckle (Lonicera) in southwestern Ohio in the fall. Ohio Journal of Science 83:256-258.

Jamison, B. E., R. J. Robel, J. S. Pontius, and R. D. Applegate. 2002. Invertebrate biomass: associations with lesser prairie-chicken habitat use and sand sagebrush density in southwestern Kansas. Wildlife Society Bulletin 30:517-526.

Johnson, M. D. 2000. Evaluation of an arthropod sampling technique for measuring food availability for forest insectivorous birds. Journal of Field Ornithology 71:88-109.

Johnson, M. D., and T. W. Sherry. 2001. Effects of food availability on the distribution of migratory warblers among habitats in Jamaica. Journal of Animal Ecology 70:546-560.

Karasov, W. H. 1990. Digestion in birds: chemical and physiological determinants and ecological applications. Studies in Avian Biology 13:391-415. 
Kartesz, J. T. 1999. Synthesis of the North American flora. Version 1.0. North Carolina Botanical Garden, Chapel Hill.

Kelso, G. K. 1994. Palynology in historical rural landscape studies: the pre-clearance forest border at Great Meadows, Pennsylvania. National Park Service, Technical Report NPS/MARFONE/NRTR - 95/067.

Kopas, F. A. 1973. Soil survey of Fayette County, Pennsylvania. U.S. Department of Agriculture, Soil Conservation Service, U.S. Government Printing Office, Washington D.C.

Krebs, J. R., and R. H. McCleery. 1984. Optimization in behavioral ecology. Pages 91-121 in J. R. Krebs, editor. Behavioral ecology: an evolutionary approach. Blackwell Scientific, Oxford, United Kingdom.

Levine, J. M. 2000. Species diversity and biological invasions: relating local process to community pattern. Science 288:852-854.

Lindsay, E. A., and K. French. 2006. The impact of the weed Chrysanthemoides monilifera spp. rotundata on coastal leaf litter invertebrates. Biological Invasions 8:177-192.

Lodge, D. M. 1993. Biological invasions: lessons for ecology. Trends in Ecology and Evolution 8:133-137.

Luken, J. O. 1988. Population structure and biomass allocation of the naturalized shrub Lonicera maackii (Rupr.) Maxim. in forest and open habitats. American Midland Naturalist 119:258-267.

Luken, J. O., and N. Goessling. 1995. Seedling distribution and potential persistence of the exotic shrub Lonicera maackii in fragmented forests. American Midland Naturalist 133:124-130. 
Luken, J. O., and J. W. Thieret. 1995. Amur honeysuckle (Lonicera maackii, Caprifoliaceae): its ascent, decline, and fall. Sida 16:479-503.

Mack, R. N., and W. M. Lonsdale. 2001. Humans as global plant dispersers: getting more than we bargained for. BioScience 51:95-102.

Mahr, D. L., and T. G. Dittl. 1986. Chemical, natural, and cultural control of Hyadaphis tataricae (Homoptera: Aphididae) on honeysuckle. The Great Lakes Entomologist 19:91100.

Marra, P. P., K. A. Hobson, and R. T. Holmes. 1998. Linking winter and summer events in a migratory bird using stable-carbon isotopes. Science 282:1884-1886.

McEvoy, N. L., and R. D. Durtsche. 2004. Effect of the invasive shrub Lonicera maackii (Caprifoliaceae; Amur honeysuckle) on autumn herptofauna biodiversity. Journal of the Kentucky Academy of Science 65:27-32.

Miller, K. E., and D. L. Gorchov. 2004. The invasive shrub, Lonicera maackii, reduces growth and fecundity of perennial forest herbs. Oecologia 139:359-375.

Murdoch, W. W., F. C. Evan, and C. H. Peterson. 1972. Diversity and pattern in plants and insects. Ecology 53:819-829.

NatureServe. 2005. NatureServe Explorer: An online encyclopedia of life [web application]. Version 4.6. NatureServe, Arlington, Virginia. Available from http://www.natureserve.org/explorer (Accessed February 2006).

Nolan, Jr., V., E. D. Ketterson, and C. A. Buerkle. 1999. Prairie Warbler (Dendroica discolor). In A. Poole and F. Gill, editors. The Birds of North America, No. 455. The Birds of North America, Inc., Philadelphia, Pennsylvania. 
Osborne, K. H., and W. W. Allen. 1999. Allen-vac: an internal collection bag retainer allows for snag-free arthropod sampling in woody scrub. Environmental Entomology 28:594-596.

Parmenter, R. B., J. A. MacMahon, and C. A. B. Gilbert. 1991. Early successional patterns of arthropod recolonization on reclaimed Wyoming strip mines: the grasshoppers (Orthoptera: Gryllacrididae, Tettigoniidae). Environmental Entomology 20:135-142.

Petal, J. 1978. The role of ants in ecosystems. Pages 293-325 in M. V. Brian, editor. Production ecology of ants and termites. Cambridge University Press, Cambridge, England.

Pimentel, D., L. Lach, R. Zuniga, and D. Morrison. 2000. Environmental and economic costs of nonindigenous species in the United States. BioScience 50:53-65.

Rasband, W. S. 2005. ImageJ. U.S. National Institute of Health, Bethesda, Maryland. Software available from http://rsb.info.nih.gov/ij/ (accessed December 2005).

Rehder, A. 1940. A manual of cultivated trees and shrubs. $2^{\text {nd }}$ edition. MacMillan Publishing Company, New York, New York.

Rejmánek, M., and D. M. Richardson. 1996. What attributes make some plant species more invasive? Ecology 77:1655-1661.

Rhoads, A. F., and W. K. Klein, Jr. 1993. The vascular flora of Pennsylvania: annotated checklist and atlas. American Philosophical Society, Philadelphia, Pennsylvania.

Rickets, T. H. 2001. The matrix matters: effective isolation in fragmented landscapes. American Naturalist 158:87-99.

Ries, L., D. M. Debinski, and M. L. Wieland. 2001. Conservation value of roadside prairie restoration to butterfly communities. Conservation Biology 15:401-411.

Rodewald, A. D., and A. C. Vitz. 2005. Edge- and area-sensitivity of shrubland birds. Journal of Wildlife Management 69:681-688. 
Rodewald, P. G., and M. C. Brittingham. 2004. Stopover habitats of landbirds during fall: use of edge-dominated and early successional forests. Auk 121:1040-1055.

Rogers, L. E., R. L. Buschbom, and C. R. Watson. 1977. Length-weight relationships of shrubsteppe invertebrates. Annals of the Entomological Society of America 70:51-53.

Roland, J., N. Keyghobadi, and S. Fownes. 2000. Alpine Parnassius butterfly dispersal: effects of landscape and population size. Ecology 81:1642-1653.

Sabo, J. L., J. L. Bastow, and M. E. Power. 2002. Length-mass relationships for adult aquatic and terrestrial invertebrates in a California watershed. Journal of the North American Benthological Society 21:336-343.

Sample, B. E., R. J. Cooper, R. D. Greer, and R. C. Whitmore. 1993a. Estimation of insect biomass by length and width. American Midland Naturalist 129:234-240.

Sample, B. E., R. J. Cooper, and R. C. Whitmore. 1993b. Dietary shifts among songbirds from a diflubenzuron-treated forest. Condor 95:616-624.

Samways, M. J., P. M. Caldwell, and R. Osborn. 1996. Ground-living invertebrate assemblages in native, planted and invasive vegetation in South Africa. Agriculture, Ecosystems and Environment 59:19-32.

Schierenbeck, K. A., R. N. Mack, and R. R. Sharitz. 1994. Effects of herbivory on growth and biomass allocation in native and introduced species of Lonicera. Ecology 75:1661-1672.

Schmidt, K. A., and C. J. Whelan. 1999. Effects of exotic Lonicera and Rhamnus on songbird nest predation. Conservation Biology 13:1502-1506.

Schoener, T. W. 1980. Length-weight regressions in tropical and temperate forest-understory insects. Annals of the Entomological Society of America 73:106-109. 
Schowalter, T. D., J. W. Webb, and D. A. Crossley, Jr. 1981. Community structure and nutrient content of canopy arthropods in clearcut and uncut forest ecosystems. Ecology 62:10101019.

Sinclair, W. A., H. H. Lyon, and W. T. Johnson. 1987. Diseases of shrubs and trees. Comstock Publishing Associates, Cornell University Press, Ithaca, New York.

Slobodchikoff, C. N., and J. T. Doyen. 1977. Effects of Ammophila arenaria on sand dune arthropod communities. Ecology 58:1171-1175.

Steenkamp, H. E., and S. L. Chown. 1996. Influence of dense stands of an exotic tree, Prosopis glandulosa Benson, on a savanna dung beetle (Coleoptera: Scarabaeinae) assemblage in South Africa. Biological Conservation 78:305-311.

Strong, D. R., J. H. Lawton, and T. R. E. Southwood. 1984. Insects on plants. Harvard University Press, Cambridge, Massachusetts.

Tallamy, D. M. 2004. Do alien plants reduce insect biomass? Conservation Biology 18:16891692.

Tilman, D. 1999. The ecological consequences of changes in biodiversity: a search for general principles. Ecology 80:1455-1474.

Trisel, D. E., and D. L. Gorchov. 1994. Regional distribution, ecological impact, and leaf phenology of the invasive shrub, Lonicera maackii. Bulletin of the Ecological Society of America 75(Supplement):231-232.

Trisel, D. E. 1997. The invasive shrub, Lonicera maackii (Rupr.) Herder (Caprifoliaceae): factors contributing to its success and its effect on native species. Ph.D. Dissertation. Miami University, Oxford, Ohio. 
VanDruff, L. W., E. G. Bolen, and G. J. San Julian. 1996. Management of urban wildlife. Pages 507-530 in T. A. Bookhout, editor. Research and management techniques for wildlife and habitats. $5^{\text {th }}$ edition. The Wildlife Society. Allen Press, Inc., Lawrence, Kansas.

Vellend, M. 2002. A pest and an invader: white-tailed deer (Odocoileus virginianus Zimm.) as a seed dispersal agent for honeysuckle shrubs (Lonicera L.). Natural Areas Journal 22:230234.

Vitousek, P. M., L. R. Walker, L. D. Whiteaker, D. Mueller-Dombois, and P. A. Matson. 1987. Biological invasion by Myrica faya alters ecosystem development in Hawaii. Science 238:802-804.

Wang, C., J. S. Strazanac, and L. Butler. 2001. Association between ants (Hymenoptera: Formicidae) and habitat characteristics in oak-dominated forests. Environmental Entomology 30:842-848.

Way, M. J. 1963. Mutualism between ants and honeydew-producing Homoptera. Annual Review of Entomology 8:307-344.

Webb, C. E., I. Oliver, and A. J. Pik. 2000. Does coastal foredune stabilization with Ammophila arenaria restore plant and arthropod communities in southeastern Australia? Restoration Ecology 8:283-288.

Webb, N. R., R. T. Clarke, and J. T. Nicholas. 1984. Invertebrate diversity on fragmented Calluna-heathland: effects of surrounding vegetation. Journal of Biogeography 11:41-46.

Whelan, C. J., and M. L. Dilger. 1992. Invasive, exotic shrubs: a paradox for natural area managers? Natural Areas Journal 12:109-110.

White, D. W., and E. W. Stiles. 1992. Bird dispersal of fruits in species introduced into eastern North America. Canadian Journal of Botany 70:1689-1696. 
Williams, K. S. 1993. Use of terrestrial arthropods to evaluate restored riparian woodlands. Restoration Ecology 1:107-117.

Woods, K. D. 1993. Effects of invasion by Lonicera tatarica L. on herbs and tree seedlings in four New England forests. American Midland Naturalist 130:62-74.

Yela, J. L., and J. H. Lawton. 1997. Insect herbivore loads on native and introduced plants: a preliminary study. Entomologia Experimentalis et Applicata 85:275-279.

Zanette, L., P. Doyle, and S. M. Trémont. 2000. Food shortage in small fragments: evidence from an area-sensitive passerine. Ecology 81:1654-1666. 
Table 1. Biotic and abiotic habitat parameters, measured in the understory of a degraded meadow, included in linear regression models explaining microhabitat relationships of invertebrate abundance and biomass at Fort Necessity National Battlefield, Pennsylvania, U.S.A.

\begin{tabular}{|c|c|c|c|}
\hline Variable & Units & Abbreviation & Additional description \\
\hline Shrub type & Categorical & $\mathrm{SH}$ & $\begin{array}{l}\text { Morrow's honeysuckle, southern arrowwood, dense } \\
\text { thickets of Morrow's honeysuckle, or open plots }\end{array}$ \\
\hline Herb cover & $\%$ & $\mathrm{HC}$ & $\%$ total herb cover within the plot \\
\hline $\begin{array}{l}\text { Native herb } \\
\text { cover }\end{array}$ & $\%$ & $\mathrm{NC}$ & Ratio of native herb cover to total herb cover \\
\hline Litter mass & g & LM & Leaf litter dry weight within plot \\
\hline Litter nitrogen & $\%$ & LN & $\%$ litter nitrogen within plot \\
\hline Soil moisture & $\%$ & SM & $\%$ moisture content of $20 \mathrm{~g}$ sample of soil from plot \\
\hline Soil temperature & ${ }^{\circ} \mathrm{C}$ & $\mathrm{ST}$ & Soil temperature to a depth of $4 \mathrm{~cm}$ \\
\hline Debris mass & $\mathrm{g}$ & $\mathrm{DM}$ & Wet weight of debris collected in vacuum within plot \\
\hline
\end{tabular}


Table 2. Linear regression models explaining influence of biotic and abiotic environmental variables on patterns of invertebrate abundance under different shrub types during different months in a degraded meadow at Fort Necessity National Battlefield, Pennsylvania, U.S.A. Model rankings were based on Akaike's Information Criterion corrected for small sample size $\left(\mathrm{AIC}_{\mathrm{c}}\right)$.

\begin{tabular}{|c|c|c|c|c|c|}
\hline Model $^{a}$ & $R^{2}$ & $K^{b}$ & $(Q) A I C_{c}^{\mathrm{c}}$ & $\Delta(Q) A I C_{c}^{\mathrm{d}}$ & $w_{i}^{\mathrm{e}}$ \\
\hline \multicolumn{6}{|l|}{ May $(n=59)$} \\
\hline Shrub $(\mathrm{SH})$ & 0.36 & 7 & 154.82 & 0.00 & 0.99 \\
\hline Debris $(D M)$ & 0.09 & 4 & 164.96 & 10.14 & 0.01 \\
\hline Native herbs $(N C)$ & 0.03 & 4 & 168.91 & 14.10 & 0.00 \\
\hline Total herbs $(H C)$ & 0.03 & 4 & 169.07 & 14.25 & 0.00 \\
\hline Litter $(L M, L N)$ & 0.05 & 5 & 170.17 & 15.35 & 0.00 \\
\hline Soil (SM, ST) & 0.01 & 5 & 172.06 & 17.24 & 0.00 \\
\hline Global $(S H, H C, N C, L M, L N, S M, S T, D M)$ & 0.38 & 14 & 172.56 & 17.74 & 0.00 \\
\hline \multicolumn{6}{|l|}{ July $(n=50)$} \\
\hline Total herbs $(H C)$ & 0.26 & 3 & 136.55 & 0.00 & 0.97 \\
\hline Debris $(D M)$ & 0.13 & 3 & 144.80 & 8.25 & 0.02 \\
\hline Shrub $(S H)$ & 0.25 & 6 & 144.85 & 8.30 & 0.02 \\
\hline Soil $(S M, S T)$ & 0.08 & 4 & 149.84 & 13.29 & 0.00 \\
\hline Native herbs $(N C)$ & 0.03 & 3 & 150.12 & 13.57 & 0.00 \\
\hline Litter $(L M, L N)$ & 0.06 & 4 & 150.92 & 14.38 & 0.00 \\
\hline Global (SH, HC, NC, LM, LN, SM, ST, DM) & 0.43 & 13 & 153.20 & 16.65 & 0.00 \\
\hline \multicolumn{6}{|l|}{ August $(n=58)$} \\
\hline Total herbs $(H C)$ & 0.03 & 3 & 181.67 & 0.00 & 0.40 \\
\hline Debris $(D M)$ & 0.01 & 3 & 182.72 & 1.04 & 0.24 \\
\hline Native herbs $(N C)$ & 0.01 & 3 & 183.00 & 1.33 & 0.21 \\
\hline Soil (SM, ST) & 0.01 & 4 & 185.00 & 3.33 & 0.08 \\
\hline Litter $(L M, L N)$ & $<0.01$ & 4 & 185.51 & 3.84 & 0.06 \\
\hline Shrub (SH) & 0.03 & 6 & 188.89 & 7.21 & 0.01 \\
\hline Global $(S H, H C, N C, L M, L N, S M, S T, D M)$ & 0.12 & 13 & 203.72 & 22.04 & 0.00 \\
\hline
\end{tabular}


Table 2. Continued.

${ }^{\text {a }}$ Abbreviations in parentheses correspond to model parameters in Table 1.

${ }^{\mathrm{b}}$ Number of estimable parameters in approximating model. For May, there is one extra parameter added to take into account the estimation of $c$, the variance inflation factor.

${ }^{\mathrm{c}}$ In May, we used QAIC ${ }_{\mathrm{c}}$; for July and August we used $\mathrm{AIC}_{\mathrm{c}}$

${ }^{\mathrm{d}}$ Difference in value between $\mathrm{AIC}_{\mathrm{c}}\left(\right.$ or $\mathrm{QAIC}_{\mathrm{c}}$ ) of the current model versus the bestapproximating model $\left(\mathrm{AIC}_{\mathrm{cmin}}\right)$.

${ }^{\mathrm{e}}$ Akaike weight. Probability that the current model (i) is the best-approximating model among those considered. 
Table 3. Linear regression models explaining influence of biotic and abiotic environmental variables on patterns of invertebrate biomass under different shrub types during different months in a degraded meadow at Fort Necessity National Battlefield, Pennsylvania, U.S.A. Model rankings were based on Akaike's Information Criterion corrected for small sample size $\left(\mathrm{AIC}_{\mathrm{c}}\right)$.

\begin{tabular}{|c|c|c|c|c|c|}
\hline Model & $R^{2}$ & $K^{b}$ & $A I C_{c}$ & $\triangle A I C_{c}^{\mathrm{c}}$ & $w_{i}^{\mathrm{d}}$ \\
\hline \multicolumn{6}{|l|}{ May $(n=59)$} \\
\hline Total herbs $(H C)$ & 0.04 & 3 & 194.44 & 0.00 & 0.47 \\
\hline Debris $(D M)$ & 0.01 & 3 & 196.29 & 1.85 & 0.19 \\
\hline Native herbs $(N C)$ & $<0.01$ & 3 & 196.95 & 2.51 & 0.13 \\
\hline Litter $(L M, L N)$ & 0.03 & 4 & 197.53 & 3.09 & 0.10 \\
\hline Shrub $(S H)$ & 0.09 & 6 & 198.81 & 4.37 & 0.05 \\
\hline Soil $(S M, S T)$ & 0.01 & 4 & 198.91 & 4.47 & 0.05 \\
\hline Global (SH, HC, NC, LM, LN, SM, ST, DM) & 0.16 & 13 & 214.69 & 20.25 & 0.00 \\
\hline \multicolumn{6}{|l|}{ July $(n=50)$} \\
\hline Total herbs $(H C)$ & 0.16 & 3 & 55.47 & 0.00 & 0.81 \\
\hline Debris $(D M)$ & 0.10 & 3 & 59.03 & 3.56 & 0.14 \\
\hline Native herbs $(N C)$ & 0.03 & 3 & 62.57 & 7.10 & 0.02 \\
\hline Shrub $(S H)$ & 0.13 & 6 & 64.42 & 8.95 & 0.01 \\
\hline Litter $(L M, L N)$ & 0.04 & 4 & 64.59 & 9.12 & 0.01 \\
\hline Soil $(S M, S T)$ & 0.04 & 4 & 64.64 & 9.17 & 0.01 \\
\hline Global (SH, HC, NC, LM, LN, SM, ST, DM) & 0.26 & 13 & 78.90 & 13.84 & 0.00 \\
\hline \multicolumn{6}{|l|}{ August $(n=58)$} \\
\hline Shrub $(S H)$ & 0.15 & 6 & 105.04 & 0.00 & 0.47 \\
\hline Native herbs $(N C)$ & 0.01 & 3 & 107.05 & 2.00 & 0.17 \\
\hline Debris $(D M)$ & $<0.01$ & 3 & 107.56 & 2.52 & 0.13 \\
\hline Total herbs $(H C)$ & $<0.01$ & 3 & 107.59 & 2.54 & 0.13 \\
\hline Litter $(L M, L N)$ & 0.01 & 4 & 109.41 & 4.37 & 0.05 \\
\hline Soil $(S M, S T)$ & $<0.01$ & 4 & 109.87 & 4.83 & 0.04 \\
\hline Global (SH, HC, NC, LM, LN, SM, ST, DM) & 0.17 & 13 & 124.09 & 19.05 & 0.00 \\
\hline
\end{tabular}


Table 3. Continued.

${ }^{\text {a }}$ Abbreviations in parentheses correspond to model parameters in Table 1.

${ }^{\mathrm{b}}$ Number of estimable parameters in approximating model.

${ }^{\mathrm{c}}$ Difference in value between $\mathrm{AIC}_{\mathrm{c}}$ of the current model versus the best-approximating model $\left(\mathrm{AIC}_{\mathrm{cmin}}\right)$.

${ }^{d}$ Akaike weight. Probability that the current model (i) is the best-approximating model among those considered. 
Table 4. The five most common invertebrates ( $\geq 2 \mathrm{~mm}$ in length) collected from the shrub strata of three shrub types $(n=45)$ based on abundance (total number of invertebrates per Family) and biomass (total dry weight (mg)) at Fort Necessity National Battlefield, Pennsylvania, U.S.A.

\begin{tabular}{|c|c|c|c|c|c|c|c|c|c|c|}
\hline \multirow[b]{2}{*}{ Shrub type } & \multicolumn{5}{|c|}{ Top 5 based on total abundance } & \multicolumn{5}{|c|}{ Top 5 based on total biomass ( $\mathrm{mg}$ ) } \\
\hline & Order & Family & $n$ & $w t$. & $f^{\mathrm{a}}$ & Order & Family $^{\mathrm{b}}$ & $w t$. & $n$ & $f$ \\
\hline $\begin{array}{l}\text { Lone } \\
\text { Morrow's }\end{array}$ & Homoptera & Cicadellidae & 267 & 130.4 & 40 & Opiliones & Phalangiidae & 180.3 & 23 & 15 \\
\hline \multirow{4}{*}{$\underline{\underline{\text { honeysuckle }}}$} & Coleoptera & Staphylinidae & 72 & 53.2 & 6 & Hymentoptera & Apidae & 136.1 & 3 & 2 \\
\hline & Hymenoptera & Formicidae & 58 & 20.3 & 19 & Homoptera & Cicadellidae & 130.4 & 267 & 40 \\
\hline & Homoptera & Psyllidae & 58 & 22.3 & 16 & Hemiptera & Pentatomidae & 122.2 & 27 & 16 \\
\hline & Diptera & Chironomidae & 40 & 10.0 & 8 & Orthoptera & Gryllidae & 110.6 & 14 & 10 \\
\hline \multirow{5}{*}{$\begin{array}{l}\text { Lone } \\
\text { southern } \\
\text { arrowwood } \\
\underline{\text { shrubs }}\end{array}$} & Hymenoptera & Formicidae & 292 & 121.8 & 32 & Coleoptera & Coccinellidae & 266.0 & 17 & 13 \\
\hline & Homoptera & Cicadellidae & 106 & 87.3 & 32 & Hemiptera & Pentatomidae & 124.9 & 33 & 10 \\
\hline & Hymenoptera & Scelionidae & 67 & 9.9 & 26 & Hymenoptera & Formicidae & 121.8 & 292 & 32 \\
\hline & Diptera & Chironomidae & 67 & 17.8 & 7 & Hymenoptera & Symphyta & 98.9 & 28 & 14 \\
\hline & Homoptera & Aphididae & 62 & 13.0 & 5 & Homoptera & Cicadellidae & 87.3 & 106 & 32 \\
\hline \multirow{5}{*}{$\begin{array}{l}\frac{\text { Dense }}{\text { thickets of }} \\
\text { Morrow's } \\
\text { honeysuckle }\end{array}$} & Homoptera & Cicadellidae & 139 & 78.0 & 40 & Opiliones & Phalangiidae & 171.3 & 27 & 22 \\
\hline & Diptera & Drosophilidae & 59 & 16.4 & 21 & Coleoptera & Chrysomelidae & 131.2 & 19 & 10 \\
\hline & Hemiptera & Miridae & 47 & 33.1 & 22 & Hemiptera & Pentatomidae & 130.4 & 23 & 14 \\
\hline & Hemiptera & Reduviidae & 41 & 75.6 & 20 & Orthoptera & Acrididae & 129.0 & 14 & 8 \\
\hline & Coleoptera & Staphylinidae & 34 & 29.3 & 9 & Hemiptera & Coreidae & 96.9 & 7 & 6 \\
\hline
\end{tabular}

\footnotetext{
${ }^{\text {a }}$ Frequency (number of occurrences out of 45)

${ }^{\mathrm{b}}$ Symphyta is a suborder; these specimens were also larvae.
} 
Table 5. Mean ( $\pm \mathrm{SE}$ ) abundance, biomass (dry weight (mg)), and richness (Family or lowest taxonomic group) of invertebrates ( $\geq 2 \mathrm{~mm}$ in length) sampled within the shrub strata based on shrub type and month at Fort Necessity National Battlefield, Pennsylvania, U.S.A.

\begin{tabular}{lcccc}
\hline & & Abundance & Biomass (mg) & Richness \\
\cline { 4 - 5 } Variable & $n$ & $\bar{X} \pm S E^{*}$ & $\bar{X} \pm S E$ & $\bar{X} \pm S E$ \\
\hline Shrub type & 45 & $24.0 \pm 2.2 \mathrm{~A}$ & $41.8 \pm 6.3 \mathrm{~A}$ & $10.7 \pm 0.7 \mathrm{~A}$ \\
Lone Morrow's honeysuckle shrubs & 45 & $25.8 \pm 3.0 \mathrm{~A}$ & $28.3 \pm 3.8 \mathrm{~B}$ & $10.3 \pm 0.7 \mathrm{~A}$ \\
Lone southern arrowwood shrubs & 45 & $19.9 \pm 1.6 \mathrm{~A}$ & $38.8 \pm 4.2 \mathrm{~A}$ & $11.0 \pm 0.6 \mathrm{~A}$ \\
Dense thickets of Morrow's honeysuckle & 45 & & \\
Month & & & & \\
\hline May & 45 & $26.4 \pm 3.0 \mathrm{~A}$ & $30.6 \pm 4.1 \mathrm{~A}$ & $10.5 \pm 0.6 \mathrm{~B}$ \\
July & 45 & $26.8 \pm 1.8 \mathrm{~A}$ & $39.2 \pm 3.3 \mathrm{~A}$ & $13.2 \pm 0.6 \mathrm{~A}$ \\
August & 45 & $16.4 \pm 1.5 \mathrm{~B}$ & $39.2 \pm 6.7 \mathrm{~A}$ & $8.3 \pm 0.6 \mathrm{C}$ \\
\hline
\end{tabular}

* Means in columns with different letters and under different variables are significantly different $(p<0.05)$, based on Duncan's multiple range tests. 
Table 6. The five most common invertebrates ( $\geq 2 \mathrm{~mm}$ in length) collected from the understory of four shrub types ( $n=45)$ based on abundance (total number of invertebrates per Family) and biomass (total dry weight (mg)) at Fort Necessity National Battlefield, Pennsylvania, U.S.A.

\begin{tabular}{|c|c|c|c|c|c|c|c|c|c|c|}
\hline \multirow[b]{2}{*}{ Shrub type } & \multicolumn{5}{|c|}{ Top 5 based on total abundance } & \multicolumn{5}{|c|}{ Top 5 based on total biomass $(\mathrm{mg})$} \\
\hline & Order & Family $^{\mathrm{a}}$ & $n$ & $w t$. & $f^{b}$ & Order & Family $^{\mathrm{a}}$ & $w t$. & $n$ & $f$ \\
\hline \multirow{5}{*}{$\begin{array}{l}\text { Lone } \\
\text { Morrow's } \\
\underline{\text { honeysuckle }} \\
\underline{\text { shrubs }}\end{array}$} & Collembola & Isotomidae & 185 & 14.0 & 37 & Stylommatophora & - & 80.6 & 13 & 8 \\
\hline & Homoptera & Cicadellidae & 130 & 49.7 & 35 & Opiliones & Phalangiidae & 73.4 & 11 & 12 \\
\hline & Hymenoptera & Formicidae & 59 & 14.5 & 26 & Hemiptera & Pentatomidae & 59.3 & 4 & 3 \\
\hline & Coleoptera & Chrysomelidae & 30 & 2.4 & 14 & Coleoptera & Chrysomelidae & 54.2 & 18 & 17 \\
\hline & Coleoptera & Curculionidae & 27 & 29.3 & 13 & Homoptera & Cicadellidae & 49.7 & 130 & 35 \\
\hline \multirow{5}{*}{$\begin{array}{l}\text { Lone } \\
\text { southern } \\
\underline{\text { arrowwood }} \\
\underline{\text { shrubs }}\end{array}$} & Homoptera & Cicadellidae & 160 & 83.4 & 36 & Homoptera & Cicadellidae & 83.4 & 160 & 36 \\
\hline & Collembola & Isotomidae & 145 & 12.7 & 29 & Opiliones & Phalangiidae & 71.9 & 7 & 6 \\
\hline & Hymenoptera & Formicidae & 67 & 17.7 & 27 & Stylommatophora & - & 50.6 & 9 & 8 \\
\hline & Araneae & Lycosidae & 28 & 39.9 & 14 & Coleoptera & Chrysomelidae & 48.1 & 10 & 9 \\
\hline & Coleoptera & Curculionidae & 28 & 23.3 & 18 & Araneae & Lycosidae & 39.9 & 28 & 14 \\
\hline \multirow{5}{*}{$\begin{array}{l}\text { Dense } \\
\text { thickets of } \\
\text { Morrow's } \\
\text { honeysuckle }\end{array}$} & Collembola & Isotomidae & 106 & 8.1 & 28 & Hemiptera & Pentatomidae & 85.0 & 9 & 7 \\
\hline & Homoptera & Cicadellidae & 44 & 20.0 & 18 & Stylommatophora & - & 72.1 & 13 & 12 \\
\hline & Hymenoptera & Formicidae & 38 & 11.6 & 17 & Coleoptera & Curculionidae & 30.8 & 23 & 14 \\
\hline & Coleoptera & Curculionidae & 23 & 30.8 & 14 & Homoptera & Cicadellidae & 20.0 & 44 & 18 \\
\hline & Diptera & Sciaridae & 17 & 3.8 & 6 & Araneae & Thomasidae & 20.0 & 1 & 1 \\
\hline \multirow{5}{*}{$\frac{\text { Open plots }}{\underline{\text { with no }}}$} & Homoptera & Cicadellidae & 195 & 97.7 & 37 & Homoptera & Cicadellidae & 97.7 & 195 & 37 \\
\hline & Collembola & Isotomidae & 152 & 8.4 & 31 & Araneae & Lycosidae & 65.6 & 31 & 16 \\
\hline & Hymenoptera & Formicidae & 70 & 37.2 & 21 & Stylommatophora & - & 45.4 & 7 & 7 \\
\hline & Coleoptera & Chrysomelidae & 54 & 4.0 & 10 & Lepidoptera & Noctuidae & 38.8 & 10 & 5 \\
\hline & Homoptera & Psyllidae & 44 & 15.2 & 16 & Hymenoptera & Formicidae & 37.2 & 70 & 21 \\
\hline
\end{tabular}

${ }^{\text {a }}$ Specimens in the Families Chrysomeldidae and Noctuidae are larvae (caterpillars).

${ }^{b}$ Frequency (number of occurrences out of 45) 
Table 7. Mean ( \pm SE) abundance, biomass (dry weight (mg)), and richness (Family or lowest taxonomic group) of invertebrates ( $\geq 2 \mathrm{~mm}$ in length) sampled in the understory based on shrub type and month at Fort Necessity National Battlefield, Pennsylvania, U.S.A.

\begin{tabular}{lcccc}
\hline & & Abundance & Biomass (mg) & Richness \\
\cline { 5 - 5 } Variable & $n$ & $\bar{X} \pm S E^{*}$ & $\bar{X} \pm S E$ & $\bar{X} \pm S E$ \\
\hline Shrub type & 45 & $15.8 \pm 1.1 \mathrm{~A}$ & $14.5 \pm 2.0 \mathrm{~A}$ & $7.7 \pm 0.4 \mathrm{~A}$ \\
Lone Morrow's honeysuckle shrubs & 45 & $15.6 \pm 1.2 \mathrm{~A}$ & $14.5 \pm 1.7 \mathrm{~A}$ & $7.5 \pm 0.5 \mathrm{~A}$ \\
Lone southern arrowwood shrubs & 45 & $9.2 \pm 1.1 \mathrm{~B}$ & $8.6 \pm 1.8 \mathrm{~B}$ & $5.3 \pm 0.4 \mathrm{~B}$ \\
Dense thickets of Morrow's honeysuckle & 45 & & & \\
Open plots with no overstory & 45 & $16.8 \pm 2.0 \mathrm{~A}$ & $12.3 \pm 2.0 \mathrm{AB}$ & $6.5 \pm 0.5 \mathrm{~B}$ \\
Month & & & & \\
May & 60 & $18.6 \pm 1.3 \mathrm{~A}$ & $11.6 \pm 1.1 \mathrm{~A}$ & $7.6 \pm 0.4 \mathrm{~A}$ \\
July & 60 & $15.2 \pm 1.2 \mathrm{~B}$ & $12.7 \pm 1.7 \mathrm{~A}$ & $7.3 \pm 0.4 \mathrm{~A}$ \\
August & 60 & $9.4 \pm 0.9 \mathrm{C}$ & $13.2 \pm 2.0 \mathrm{~A}$ & $5.4 \pm 0.4 \mathrm{~B}$ \\
\hline
\end{tabular}

* Means in columns with different letters are significantly different $(p<0.05)$, based on Duncan's multiple range tests. 
Table 8. Mean $( \pm \mathrm{SE})$ values of microhabitat variables recorded under Morrow's honeysuckle shrubs (L), southern arrowwood shrubs (V), dense thickets of Morrow's honeysuckle (X), and open plots with no shrub cover $(\mathrm{O})$ based on month at Fort Necessity National Battlefield, Pennsylvania, U.S.A.

\begin{tabular}{|c|c|c|c|c|}
\hline \multirow[b]{3}{*}{ Microhabitat variables $^{\mathrm{a}}$} & \multicolumn{4}{|c|}{ Shrub type } \\
\hline & $L$ & $V$ & $X$ & $O$ \\
\hline & $\bar{X} \pm S E$ & $\bar{X} \pm S E$ & $\bar{X} \pm S E$ & $\bar{X} \pm S E$ \\
\hline \multicolumn{5}{|l|}{ May, $n=58$} \\
\hline Herb cover $(\%)$ & $50.2 \pm 5.6$ & $49.6 \pm 5.4$ & $34.1 \pm 5.3$ & $75.0 \pm 4.1$ \\
\hline Native cover: total cover (\%) & $48.5 \pm 6.9$ & $64.8 \pm 5.4$ & $39.4 \pm 5.9$ & $61.7 \pm 6.1$ \\
\hline Dry litter wt. (g) & $21.57 \pm 4.27$ & $30.99 \pm 5.35$ & $20.66 \pm 4.84$ & $17.16 \pm 3.01$ \\
\hline Litter N (\%) & $1.30 \pm 0.12$ & $1.49 \pm 0.08$ & $1.48 \pm 0.12$ & $1.22 \pm 0.07$ \\
\hline Soil moisture (\%) & $24.7 \pm 0.8$ & $24.7 \pm 0.7$ & $24.9 \pm 1.1$ & $23.3 \pm 0.7$ \\
\hline Soil temp. $\left({ }^{\circ} \mathrm{C}\right)$ & $15.0 \pm 0.3$ & $16.1 \pm 0.4$ & $14.8 \pm 0.3$ & $16.7 \pm 0.3$ \\
\hline Wet debris wt. (g) & $2.09 \pm 0.45$ & $1.99 \pm 0.22$ & $5.60 \pm 1.08$ & $0.62 \pm 0.09$ \\
\hline \multicolumn{5}{|l|}{$\underline{\text { July, }} n=50$} \\
\hline Herb cover $(\%)$ & $99.1 \pm 11.0$ & $106.8 \pm 10.5$ & $50.6 \pm 8.0$ & $155.5 \pm 11.7$ \\
\hline Native cover: total cover (\%) & $64.6 \pm 8.0$ & $68.3 \pm 8.1$ & $56.7 \pm 6.8$ & $72.8 \pm 7.8$ \\
\hline Dry litter wt. (g) & $13.06 \pm 3.99$ & $23.66 \pm 4.46$ & $17.10 \pm 3.37$ & $22.10 \pm 4.73$ \\
\hline Litter N (\%) & $1.07 \pm 0.12$ & $1.28 \pm 0.12$ & $1.23 \pm 0.12$ & $1.11 \pm 0.07$ \\
\hline Soil moisture (\%) & $19.9 \pm 1.14$ & $22.8 \pm 0.8$ & $21.6 \pm 0.7$ & $21.2 \pm 2.3$ \\
\hline Soil temp. $\left({ }^{\circ} \mathrm{C}\right)$ & $21.8 \pm 0.9$ & $20.4 \pm 0.4$ & $20.6 \pm 0.3$ & $22.9 \pm 0.6$ \\
\hline Wet debris wt. (g) & $1.03 \pm 0.16$ & $0.92 \pm 0.19$ & $2.86 \pm 0.52$ & $0.92 \pm 0.16$ \\
\hline \multicolumn{5}{|l|}{ August, $n=59$} \\
\hline$\overline{\text { Herb cover }(\%)}$ & $61.3 \pm 6.2$ & $64.1 \pm 7.4$ & $46.0 \pm 7.4$ & $88.9 \pm 6.3$ \\
\hline Native cover: total cover (\%) & $75.4 \pm 3.4$ & $77.7 \pm 4.5$ & $58.0 \pm 7.4$ & $81.5 \pm 4.0$ \\
\hline Dry litter wt. (g) & $19.69 \pm 2.76$ & $40.68 \pm 4.92$ & $16.00 \pm 2.94$ & $27.84 \pm 4.71$ \\
\hline Litter N (\%) & $1.27 \pm 0.12$ & $1.53 \pm 0.11$ & $1.45 \pm 0.11$ & $1.13 \pm 0.09$ \\
\hline Soil moisture (\%) & $14.2 \pm 0.5$ & $14.5 \pm 0.3$ & $13.6 \pm 0.4$ & $13.5 \pm 0.6$ \\
\hline Soil temp. $\left({ }^{\circ} \mathrm{C}\right)$ & $25.2 \pm 0.6$ & $25.3 \pm 0.7$ & $24.2 \pm 0.5$ & $26.2 \pm 0.5$ \\
\hline Wet debris wt. (g) & $2.35 \pm 0.27$ & $3.33 \pm 0.55$ & $3.31 \pm 0.51$ & $3.56 \pm 0.50$ \\
\hline
\end{tabular}


Table 8. Continued.

${ }^{a}$ Microhabitat variables correspond to model parameters in Table 1.

${ }^{\mathrm{b}} \mathrm{L}=$ single Morrow's honeysuckle shrubs; $\mathrm{V}=$ single southern arrowwood shrubs; $\mathrm{X}=$ dense thickets of Morrow's honeysuckle shrubs; and $\mathrm{O}=$ open plots with no shrub canopy. 
Table 9. Morrow's honeysuckle and southern arrowwood mean $( \pm \mathrm{SE})$ percent of leaves with evidence of herbivory, leaf area consumed $\left(\mathrm{cm}^{2}\right)$, and herbivory rank at Fort Necessity National Battlefield, Pennsylvania, U.S.A.

\begin{tabular}{lcccc}
\hline & \multicolumn{2}{c}{$\begin{array}{l}\text { Percent of leaves } \\
\text { w/evidence of } \\
\text { herbivory }\end{array}$} & $\begin{array}{c}\text { Leaf area } \\
\text { consumed }\left(\mathrm{cm}^{2}\right)\end{array}$ & Leaf rank \\
\cline { 4 - 5 } Variable & $n^{\mathrm{a}}$ & $\bar{X} \pm S E^{\mathrm{b}}$ & $\bar{X} \pm S E$ & $\bar{X} \pm S E$ \\
\hline $\begin{array}{l}\text { Shrub } \\
\text { Morrow's honeysuckle }\end{array}$ & 45 & $7.9 \pm 1.5 \% \mathrm{~B}$ & $0.12 \pm 0.03 \mathrm{~B}$ & $0.11 \pm 0.02 \mathrm{~B}$ \\
Southern arrowwood & 45 & $68.6 \pm 6.1 \% \mathrm{~A}$ & $0.38 \pm 0.07 \mathrm{~A}$ & $0.98 \pm 0.10 \mathrm{~A}$ \\
$\frac{\text { Month }}{\text { May }}$ & 30 & $7.2 \pm 2.0 \% \mathrm{~B}$ & $0.17 \pm 0.05 \mathrm{~B}$ & $0.08 \pm 0.02 \mathrm{~B}$ \\
July & 30 & $54.2 \pm 7.8 \% \mathrm{~A}$ & $0.26 \pm 0.06 \mathrm{~A}$ & $0.76 \pm 0.11 \mathrm{~A}$ \\
August & 30 & $53.3 \pm 8.4 \% \mathrm{~A}$ & $0.31 \pm 0.08 \mathrm{~A}$ & $0.79 \pm 0.13 \mathrm{~A}$ \\
\hline
\end{tabular}

${ }^{\text {a }}$ For leaf area consumed, $\mathrm{n}$ is as follows: Morrow's honeysuckle $(\mathrm{n}=42)$, southern arrowwood $(n=41)$, May $(n=25)$, July $(n=30)$, August $(n=28)$.

${ }^{\mathrm{b}}$ Means in columns with different letters are significantly different $(p<0.05)$, based on Duncan's multiple range tests. 

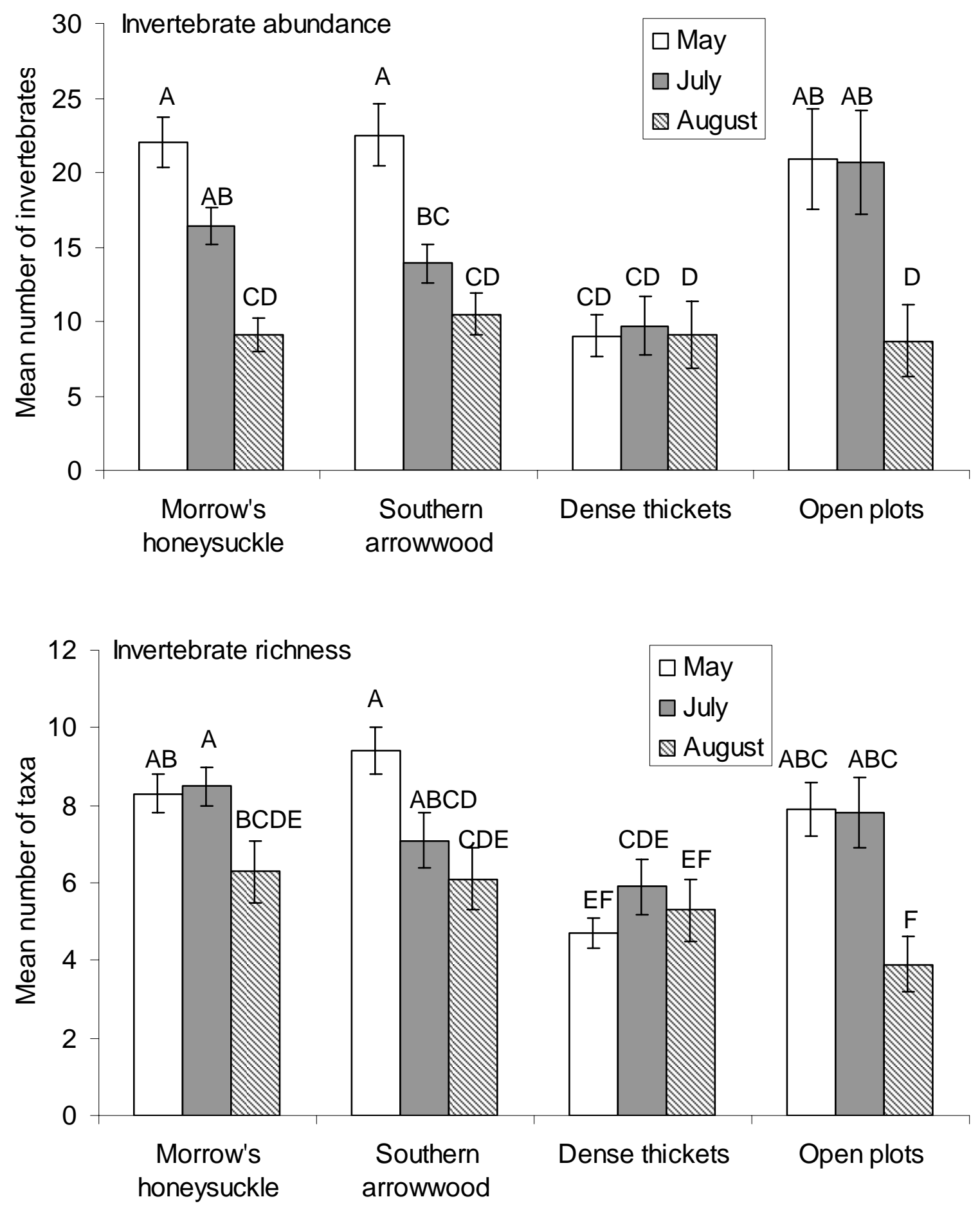

Figure 1. Mean $( \pm \mathrm{SE})$ ground-dwelling invertebrate abundance and richness differed depending on shrub understory type and month at Fort Necessity National Battlefield, Pennsylvania. Means with different letters are significantly different, based on Duncan's multiple range tests $(p<0.05)$. 


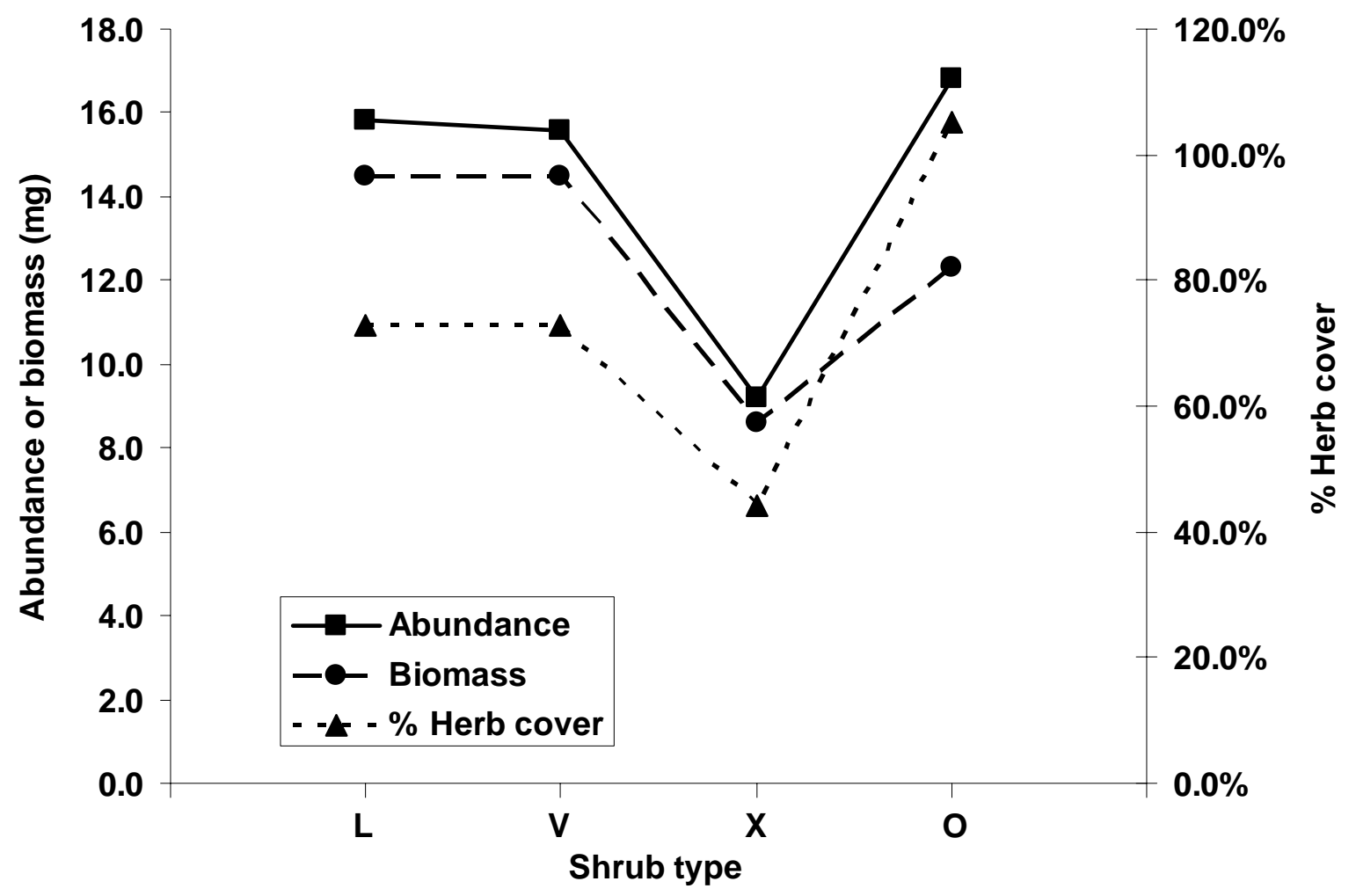

Figure 2. Ground-dwelling mean invertebrate abundance and biomass over all months was positively related to percent herbaceous cover, which in turn was regulated by shrub type ( $\mathrm{L}=$ lone Morrow's honeysuckle; $\mathrm{V}=$ lone southern arrowwood; $\mathrm{X}=$ dense thickets of Morrow's honeysuckle; and $\mathrm{O}=$ open plots with no overstory) within a degraded meadow at Fort Necessity National Battlefield, Pennsylvania, U.S.A. 

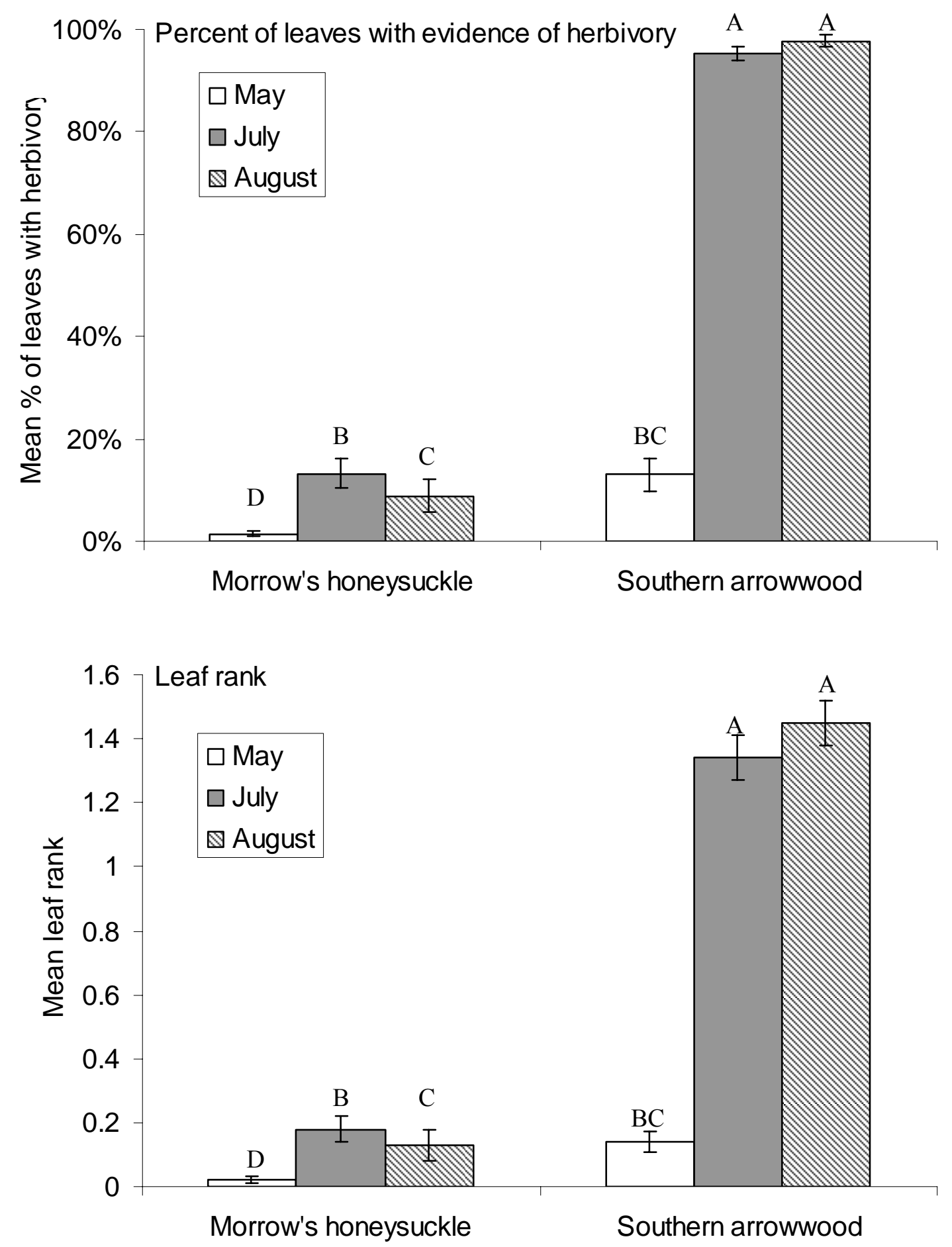

Figure 3. Mean ( \pm SE) percent of leaves with evidence of herbivory and leaf rank differed between shrub type and seasons at Fort Necessity National Battlefield, Pennsylvania. Means with different letters are significantly different, based on Duncan's multiple range tests $(p<0.05)$. 


\title{
CHAPTER 4
}

\section{CONCLUSION AND MANAGEMENT IMPLICATIONS FOR RESTORATION OF A DEGRADED MEADOW INFESTED WITH AN INVASIVE SHRUB, LONICERA MORROWII (MORROW'S HONEYSUCKLE)}

Jason P. Love ${ }^{1}$ and James T. Anderson ${ }^{1,2}$

\begin{abstract}
Lonicera morrowii (Morrow's honeysuckle) dominates a degraded meadow at Fort Necessity National Battlefield, Pennsylvania, U.S.A. We tested four removal methods of Morrow's honeysuckle during two seasons, spring and autumn. The cut, stump application of $20 \%$ glyphosate, and mechanical removal in autumn methods were not successful in eradicating the shrub $(<47 \%$ reduction of shrubs), while mechanical removal in spring and foliar application of $2 \%$ glyphosate in both seasons were somewhat successful in eradicating the shrub $(>66 \%$ reduction of shrubs). Because of deer herbivory and the application of herbicide, nearly all treatments had a reduction of native seedlings and saplings. After honeysuckle removal, all metrics measuring herbaceous community quality were significantly different $(p<0.05)$, with the exception of total evenness and mean conservation of conservatism values. We recommend applying a 2\% foliar application of glyphosate in the autumn to control Morrow's honeysuckle in
\end{abstract}

This chapter written in the style of Restoration Ecology.

\footnotetext{
${ }^{1}$ Division of Forestry and Natural Resources, West Virginia University, Morgantown, WV 26506, U.S.A.

${ }^{2}$ Address correspondence to J. T. Anderson, email wetland@wvu.edu
} 
the majority of the study area; this method was the cheapest and had the second best results. Areas that are thinly populated by the exotic shrub can be pulled by hand or with a tractor and chain.

We used a modified leaf blower to sample invertebrates in our study site. Invertebrate biomass was lowest within the native shrub, Viburnum recognitum (southern arrowwood) $(p<0.05)$. However the number and biomass of larval leaf chewers were highest in the native shrub. Invertebrate abundance, biomass, and richness was significantly reduced under dense thickets of Morrow's honeysuckle $(p<0.05)$, due to low amount of herbaceous cover beneath the shrubs. The amount of leaf area consumed by insect herbivores was 10 times more on the native shrub compared to the exotic shrub. Overall, our findings reveal that the shrubs negatively impact invertebrate communities and may ultimately impact organisms occupying higher trophic levels.

\section{Introduction}

Lonicera morrowii (Morrow's honeysuckle), a shrub native to Japan, was introduced to the United States circa 1875 (Rehder 1940). First planted in botanical gardens, bush honeysuckles, including Morrow's honeysuckle, soon became popular ornamental shrubs (Luken \& Thieret 1996). From a horticultural standpoint, they have a number of traits that make them ideal for landscaping: 1) they are virtually pest and disease-free (Trisel \& Gorchov 1994; Chapter 3); 2) they have attractive flowers and numerous red to orange berries (Sharp \& Belcher 1981; Dirr 1990; also see Figure 1, Chapter 1); 3) they tolerate wide array of different soil types and environmental conditions (Barnes \& Cottam 1974; Dirr 1990; Batcher \& Stiles 2000); 4) they have a long growing season - they are among the first shrubs to leaf-out and the last to lose their 
leaves in the autumn (Harrington et al. 1989; Woods 1993; Trisel \& Gorchov 1994; Chapter 2);

5) they grow well both in sun and shade (Barnes \& Cottam 1974; Luken \& Goessling 1995); and 6) they are easy to propagate (Dirr 1990). Because of these traits, the shrubs have been planted as shelterbelts in the Midwest (Herman \& Davidson 1997), used in mine reclamation (Wade 1985), and planted for wildlife use (Martin et al. 1951; Ripley et al. 1957; VanDruff et al. 1996).

The traits that make the shrubs ideal for horticulture also make them ideal invaders, so that today, Morrow's honeysuckle is naturalized in most northeastern and mid-Atlantic states, as well as southeastern and south-central Canada (Batcher \& Stiles 2000). Recent studies reveal that the shrubs decrease species richness and inhibit forest regeneration (Woods 1993; Collier et al. 2002; Gorchov \& Trisel 2003; Hartman \& McCarthy 2004). Honeysuckle shrubs also may increase the incidence of nest predation for some species of songbirds; branch architecture, the lack of thorns, and the low height of the shrubs may facilitate predation by Procyon lotor (raccoons), snakes, and other predators (Schmidt \& Whelan 1999; Borgmann \& Rodewald 2004). In a Kentucky forest, amphibian diversity, abundance, and body condition was less in areas infested with L. maackii (Amur honeysuckle) (McEvoy \& Durtsche 2004). Moreover, dense thickets of the shrubs decrease spider richness by reducing the structural complexity of the understory (Buddle et al. 2004). Infestations of the shrubs also lead to decreased invertebrate abundance, biomass, and abundance in the understory. Moreover, fewer larval leaf chewers were found on the shrub compared to a closely related native shrub (Chapter 3).

The General Management Plan for Fort Necessity National Battlefield (FONE) states that "the forest will be managed to prevent damage by exotic species" and "the park will manage species to help maintain health and diversity within the ecosystem, to ensure the continuation of rare, threatened, or endangered species, and to work toward reestablishing the vegetative 
conditions that existed during the historical period whenever possible" (Fort Necessity National Battlefield 1991). At Fort Necessity National Battlefield, Morrow's honeysuckle has invaded a degraded meadow on a hillside adjacent to the Great Meadows and the replica of Fort Necessity, altering the cultural landscape and impeding efforts to restore the site to its former historical and ecological condition (Fort Necessity National Battlefield 1991; C. Ranson 2004, Fort Necessity National Battlefield, personal communication). Moreover, Morrow's honeysuckle may be the cause of recent declines in two native plant species of special concern at FONE, Houstonia purpurea var. purpurea (purple bluet) and Hypericum densiflorum (bushy St. Johnswort) (Western Pennsylvania Conservancy 2003).

We tested several methods of removing Morrow's honeysuckle from the degraded meadow (Chapter 2). This research is a crucial first step in the eventual restoration of the study area. As part of this research, we also compared invertebrate abundance, biomass, and richness in the meadow. These invertebrates were sampled in 3 types of shrub strata (i.e., single, isolated shrubs of Morrow's honeysuckle; single, isolated shrubs of Viburnum recognitum (southern arrowwood); and dense thickets of Morrow's honeysuckle) and 4 types of understories (i.e., beneath single Morrow's honeysuckle shrubs, single southern arrowwood shrubs, dense thickets of Morrow's honeysuckle, and in open plots with no canopy cover) (Chapter 3).

\section{Methods}

\section{Study Site}

This study was conducted at Fort Necessity National Battlefield, a 350.5 ha park in Fayette County, southwestern Pennsylvania, U.S.A. $\left(39^{\circ} 48^{\prime} 43^{\prime \prime} \mathrm{N} \times 84^{\circ} 41^{\prime} 50^{\prime \prime} \mathrm{W}\right)$. Our study site (14.6 ha) was formerly an oak-hardwood forest, but was cleared for livestock grazing prior to 
establishment of the park in 1933 (Fort Necessity National Battlefield 1991; Kelso 1994). The pasture was maintained by mowing until the mid-1980s; it was thought that through passive management, native trees would become established, eventually approximating conditions that existed in the summer of 1754 when French and Indians hid amongst the trees, firing volleys at George Washington and his British troops within the hastily-built Fort Necessity (C. Ranson 2004, Fort Necessity National Battlefield, Farmington, Pennsylvania, personal communication). However, Morrow's honeysuckle invaded the meadow after mowing ceased, stifling recruitment and growth of native tree species.

The climate is moderate continental. Average annual temperature is $9^{\circ} \mathrm{C}$; mean summer temperature is $22^{\circ} \mathrm{C}$ and mean winter temperature is $-3^{\circ} \mathrm{C}$. Average annual precipitation is 119 cm (Fort Necessity National Battlefield 1991).

Soils in the lower slope of the study area are Philo silt loams and are derived from acidic sandstone and shale sediments. These soils are medium-textured, deep, and poor to moderately drained. Soils along the upper slope of the study area are Brinkerton and Armagh silt loams, Cavode silt loams, and Gilpin channery silt loams underlain by acidic shale and sandstone bedrock. These groups of soils are medium-textured, moderately deep, and moderate to well drained (Kopas 1973).

\section{Removal Methods}

To determine the best time to apply herbicides or mechanically remove the plant, we tracked total nonstructural carbohydrate (TNC) levels in the roots of Morrow's honeysuckle from March 2004 - February 2005. Large roots from five shrubs each month were collected, processed, and analyzed for TNC (e.g., Yemm \& Willis 1954; Sosebee 1983; Chapter 2). 
We tested 4 different treatment methods for removing Morrow’s honeysuckle: 1) mechanical removal; 2) cutting the shrubs flush to the ground; 3) cutting the shrubs and applying a 20\% solution of glyphosate (Roundup Pro; Monsanto, St. Louis, MO, U.S.A.); and 4) applying a foliar application of a solution of $2 \%$ glyphosate. We established $105 \times 5 \mathrm{~m}$ plots of each treatment type, including 5 control plots, for a total of 45 plots. We compared treatments between two seasons, spring and autumn, with 5 plots of each treatment type occurring in each of the two months (Chapter 2).

Within each of the $455 \times 5$-m plots, we established $51 \times 1-\mathrm{m}$ nested subplots to identify and record percent cover of herbaceous species. We calculated a number of different metrics to quantify the quality of the herbaceous community, including richness $(S)$, Shannon-Weiner Index of diversity $\left(H^{\prime}\right)$, evenness $\left(J^{\prime}\right)$, as well as Floristic Quality Assessment (including mean coefficient of conservatism (mean C) and Floristic Quality Index (FQI)) (Chapter 2).

\section{Invertebrates}

We sampled invertebrates in the shrub strata and in the understory below different shrub types using a modified leaf vacuum (STIHL model SH 85 D Shredder Vacuum/Blower; STIHL Incorporated, Virginia Beach, Virginia). In the shrub strata, we vacuumed the following shrubs (15 shrubs of each type during July 2004, May 2005, and August 2005) for 1 minute: 1) single Morrow's honeysuckle shrubs; 2) single southern arrowwood shrubs; and 3) dense thickets of Morrow's honeysuckle. In the understory, we sampled ground-dwelling invertebrates for 30 seconds using a $23 \mathrm{~cm}$ diameter cylinder to delineate the plot beneath the following shrub types: 1) single Morrow's honeysuckle shrubs; 2) single southern arrowwood shrubs; 3) dense thickets of Morrow's honeysuckle; and 4) open areas with no overstory. Invertebrates $\geq 2 \mathrm{~mm}$ were identified (typically to Family level), classified as adults, larvae, or pupae, and placed in vials 
containing $70 \%$ ethanol for storage. We used existing length-weight regression equations to determine biomass (dry weight) of each specimen (Chapter 3).

We used an information-theoretic approach to determine factors that might be driving patterns of invertebrate abundance and biomass in the understory (Burnham \& Anderson 2002). We measured the following environmental variables beneath each of the 4 shrub types: 1) percent herbaceous cover; 2) ratio of native herb cover to total herb cover; 3) soil temperature; 4) soil moisture; 5) leaf litter biomass (dry weight); 6) leaf litter nitrogen content; and 7) biomass of debris collected by the modified vacuum (wet weight). Shrub canopy type also was a parameter we took into consideration when we developed 7 a priori linear models describing factors influencing invertebrate abundance and biomass; a global model contained all 8 parameters, while the 6 other models represented the potential influences of biotic and abiotic factors on ground-dwelling invertebrates (Chapter 3).

We measured herbivory by collecting one live branch from each single Morrow's honeysuckle and southern arrowwood shrub sampled for invertebrates. We measured herbivory using three metrics: 1) the percent of leaves from each branch with evidence of herbivory; 2) measuring the amount of leaf area consumed using a digital camera and the software program ImageJ (ImageJ version 1.33u: Rasband 2005); and 3) ranking the amount of herbivory from each leaf from 0-5 based on visual estimation (Chapter 3).

\section{Results}

\section{Removal Methods}

Total nonstructural carbohydrates were lowest in May, immediately after leaf and flower formation; TNC levels were highest in October, as the leaves were beginning to senesce (Chapter 2). 
Prior to removal, we estimated mean ( \pm SE) density of Morrow’s honeysuckle live stems at $176,000 \pm 9,960 \mathrm{stems} / \mathrm{ha}$ and mean number of shrubs at $67,920 \pm 4,480 \mathrm{shrubs} / \mathrm{ha}$. Morrow's honeysuckle accounted for $93.6 \%$ of all live stems. The most abundant native woody shrubs included Acer rubrum (red maple) (3,400 \pm 1960 stems/ha), Viburnum dentatum var. lucidum (southern arrowwood) () (3,197 \pm 587 stems/ha), Crataegus pruinosa (waxyfruit hawthorne) (1,536 \pm 199 stems/ha), Prunus serotina (black cherry) (1,456 \pm 208 stems/ha), and Malus coronaria (sweet crabapple) (729 \pm 160 stems/ha). Mechanical removal in spring was most effective at decreasing the number of shrubs $(>91 \%)$ but was also the most labor intensive (933 hrs/ha). Cutting in autumn (13.8\% reduction) and stump application of herbicide in autumn (29.1\% reduction) were the least effective treatment methods. Foliar application had the least labor (56 hrs/ha) and cost $(\$ 770 \pm \$ 60)$, but was only marginally successful in eradicating Morrow's honeysuckle shrubs (spring: -66.4\%; autumn: -68.8\%). All treatment method-months decreased the number of native woody species, except for cut-spring $(+46.1 \%)$ and mechanicalautumn (+19.1\%). We attribute the reduction of native woody species after treatments to 1$)$ herbicide affecting non-target species, and 2) Odocoileus virginiana (white-tailed deer) herbivory. Control plots had increased number of native shrubs; though the shrubs are thought to negatively affect recruitment, they also form barriers to deer herbivory. Two new woody exotic species, Eleagnus umbellata (autumn olive) and Ailanthus altissima (tree of heaven) colonized the plots after shrub removal (Chapter 2).

Prior to removing Morrow's honeysuckle, we identified 93 herbaceous species; 68 species were native, while 25 species were exotic. The five species having the greatest pretreatment percent cover were Anthoxanthum odoratum (sweet vernal grass) $(\overline{\mathrm{X}}=8.46 \%$ ), Solidago rugosa (wrinkleleaf goldenrod) $(\overline{\mathrm{X}}=3.51 \%)$, . juncea (early goldenrod) $(\overline{\mathrm{X}}=2.64 \%)$, 
Rubus flagellaris (northern dewberry) $(\overline{\mathrm{X}}=1.96 \%)$, and Dactylis glomerata (orchard grass) $(\overline{\mathrm{X}}=$ $1.88 \%)$. Both sweet vernal grass and orchard grass are exotic cool season grasses. One species, Elymus trachycaulus (slender wheatgrass) ( $n=2$ subplots), is state-listed, having a state rank of S3. After removal, all metrics measuring herbaceous community quality were significantly different $(p<0.05)$, with the exception of total evenness and mean C. Mechanical removal in spring and cut in autumn had the overall highest values for herbaceous quality, while foliar and stump application of herbicide had the lowest values. Overall, exotic species richness increased $28 \%$ ( $n=7$ new species) while native species richness increased $2.9 \%$ ( $n=2$ new species $)$, revealing that exotic species quickly colonized areas devoid of honeysuckle (Chapter 2).

\section{Invertebrates}

We collected 3,133 invertebrates from the shrub strata of the three shrub types. Composition of invertebrates differed among shrub types. Invertebrate biomass was lower in southern arrowwood than the other two shrub types $(p<0.05)$, though larval leaf chewers were more abundant on the native shrub. Invertebrate abundance and biomass was lowest in August $(p<0.001)$, but there was no difference in biomass among months (Chapter 3$)$.

We collected 2,589 invertebrates from the understory of the four shrub types.

Composition of the invertebrates differed among shrub types. Invertebrate abundance, biomass, and richness was lowest in the understory below dense thickets of Morrow's honeysuckle $(p<0.001)$. Abundance and richness were lowest in August $(p<0.001)$, but there was no difference in invertebrate biomass among the three months (Chapter 3).

The model "total herbs" was the best-approximating model for describing patterns of ground-dwelling invertebrate abundance in July and August; the model "shrubs" was the bestapproximating model in May. The model "total herbs" was the best-approximating model 
describing patterns of invertebrate biomass in May and July; the model "shrubs" was the bestapproximating model in August (Chapter 3).

We assigned ranks to 4,465 leaves of Morrow's honeysuckle and 1,121 leaves of southern arrowwood. Compared to the exotic shrub, southern arrowwood had significantly more leaves with herbivory, more leaf area consumed, and had a higher leaf rank $(p<0.001)$. Overall, southern arrowwood had $284.3 \mathrm{~cm}^{2}$ of leaf consumed per $1 \mathrm{~m}^{2}$ of leaf area, while Morrow's honeysuckle had just $29.7 \mathrm{~cm}^{2}$ of leaf area consumed, a 10-fold difference (Chapter 3).

\section{Discussion}

\section{Management Implications}

\section{Removal methods}

To meet the park's goals of both restoring the historical forested landscape, while maintaining quality early successional habitat, we recommend removing the honeysuckle and planting half the area (the treatment area) in native hardwoods, while maintaining the remainder of the study area (the control and wetland areas) as quality early successional habitat (Figure 1) (Love et al. 2006). Reforesting the treatment area, which can be seen from the Great Meadows and the replica of Fort Necessity, will eventually approximate the vegetative conditions that occurred during the 1754 battle (Kelso 1994). Once the trees are fully grown, the restored hillside will permit a more accurate interpretation of the battle that occurred over 250 years ago.

While mechanical removal of Morrow's honeysuckle in May was the most effective method at reducing the shrub, it was also the most labor-intensive. For this reason, it is not practical to physically remove every shrub within the study area. However, there are approximately 2.75 ha where mechanical removal would be effective (Figure 2). This area is dominated by southern arrowwood and other native shrubs and trees. Morrow's honeysuckle, 
while still common, does not dominate the area. Most of the shrubs are large and should be able to be pulled-out with a tractor and chain or pried up with a pulaski. Mechanical removal would reduce the need for follow-up treatment with a native seed mix, although some seeds should still be scattered where the shrub originally stood to keep other exotics from colonizing the vacant area. We estimate total cost of this method to be $\sim \$ 6,400$, or roughly $1 / 4$ of the costs estimated from treatment study plots (i.e., $\$ 9,300 \times 2.75$ ha $\times 0.25$ ). We believe this part of the study area is at least $25 \%$ less dense than our study plots.

The areas outside the 2.75 mechanical removal area should be treated with a foliar application of $2 \%$ glyphosate in October. This method did not completely eradicate the shrub (68\% mortality); for this reason, the area should be bush-hogged the following year in May, immediately after leaf and flower formation. Cutting at this time of year will further decrease Morrow's honeysuckle and reduce the visual impact of standing dead shrubs during the growing season. Throughout the growing season, Morrow's honeysuckle and other exotic species should be spot-treated with glyphosate. We estimate the cost (not including bush-hogging in May) for treating this 11.85 ha of Morrow's honeysuckle to be $\sim \$ 9,125$ ( $\$ 2,490$ for herbicide $+\$ 6,635$ labor). These labor costs might be decreased if a tractor/sprayer is used to spray the herbicide. If adequate help from the Student Conservation Association or other volunteers are available, honeysuckle in the designated spray area can be removed by hand and/or with tractors. This method should be attempted in areas where high densities of native shrubs exist so that they will be spared from the herbicide application. There are relatively high densities of southern arrowwood along the lowest slope of the study area; other patches of native shrubs are scattered throughout the study area. These areas should be flagged prior to spraying. 
To achieve desired ecological conditions, continued restoration efforts will have to be employed following honeysuckle removal or the site will revert to a degraded meadow dominated by exotics (Figure 3). Prior to planting native seeds and saplings, the site will need to be prepared the following fall (i.e., one year after removal methods have been carried out). Site preparation can be achieved by either burning or disking. If there is enough fine material (i.e., dried grasses, leaves, etc.) then fire would reduce the honeysuckle slash and prepare the site for planting. However, if there is not enough fine material or fire remains a non-obtainable option, the site should be disked and/or chipped. Fire should be performed later in the fall (November), when conditions are drier and less humid. Disking should be performed anytime in the fall.

Following site preparation (i.e., during the same season - fall), native grasses and forbs should be planted to reduce the opportunities for colonization of exotic invasive plants and to promote favorable early successional wildlife habitat. A list of species was developed specifically for the meadow with the aid of W. Grafton (West Virginia University, Morgantown) (Table 1). Most of the species are Pennsylvania ecotypes. For best germination, the seeds of these species should be planted in the fall (W. Grafton 2005, West Virginia University, Morgantown, personal communication).

Currently there are 308 saplings of 10 different species that occur in the park's nursery. We recommend a planting of at least 1,683 saplings/ha (681 saplings/acre) placed at a spacing of $2.44 \times 2.44 \mathrm{~m}\left(8^{\prime} \times 8^{\prime}\right)$, a recommendation echoed in earlier reports (Ranson 2003). To make the area appear more "natural", the $8^{\prime} \times 8^{\prime}$ ' spacing should not be systematic (i.e., the area shouldn't look like a plantation). Approximately 6.04 ha (14.92 acres) would be planted, for a total of $\sim 10,160$ saplings. To approximate conditions prior to clearing (Kelso 1994), the type and number of saplings to be planted should be: Quercus rubra (northern red oak; $\mathrm{n}=2000$ ), $Q$. 
alba (white oak; $\mathrm{n}=2000)$, . prinus (chestnut oak; $\mathrm{n}=1500$ ), Acer saccharum (sugar maple; $\mathrm{n}$ $=1500$ ), Carya glabra or C. tomentosa (hickories; $\mathrm{n}=1000)$; Fraxinus americana (white ash; $\mathrm{n}$ $=1000)$, black cherry $(\mathrm{n}=500)$, and red maple $(\mathrm{n}=500)$. The majority of chestnut oak and hickories should be planted near the top of the slope, where conditions are drier. Fewer saplings would have to be planted if existing native shrubs and trees in the study area are left standing during the removal of Morrow's honeysuckle, though this may be difficult with a bush-hog. As mentioned earlier, these existing native species could be flagged prior to the treatment. Approximately 1,680 m of deer fencing would need to be erected around the reforested area; 880 $\mathrm{m}$ of fencing would need to be erected in the lower slope nearest the fort, while $800 \mathrm{~m}$ would need to be placed in the upper section near the nursery. If funds or lack of labor make it impossible to plant the entire treatment area, we recommend starting with the area most visible from the Great Meadows, working upslope and then in a northwestern direction away from the replica of Fort Necessity.

The early successional habitat would need to be regularly maintained or Morrow's honeysuckle and other invasive species will once again dominate the site. We recommend burning the area every 2-5 years to kill emerging exotics and promote the continued establishment of warm season grasses and native forbs. The whole study site should not be burned all at once; instead, the site should be designated into blocks (this is already the case, as the trail system neatly divides the area into burn units) and burned on a rotational basis. Burning should be performed in early spring prior to herb emergence. If burning is not an option, the area should be mowed once a year during the early spring, prior to the herb/leaf emergence. Mowing at this time warms the ground for new native seeds; this mowing regime also provides cover and seed sources for wildlife in the winter. We also suggest mowing the different "units" on a 
rotational basis to provide refugia for wildlife and maintain a diversity of early successional habitat. Spot treatment of herbicide should be performed annually to kill emerging exotics before they spread.

For maintenance of the forested area, spot application of herbicide should be performed on an annual basis to control exotics. If regular maintenance is not performed, the site will revert to a community dominated by Morrow's honeysuckle and other exotics. As the forest matures and bark thickens on the trees, we recommend burning on a 5-10 year basis. Burning promotes the establishment of oaks and prevents the spread of invasive woody species (Vose 2000).

Early successional vegetation within the treatment area would slowly succeed to a woodland herb community. The control and wetland area would persist as quality early successional habitat, making it ideal for the persistence of the 2 state-listed plants found in the study area (purple bluets and slender wheatgrass), species normally associated with old fields or prairies (Strausbaugh \& Core 1977; Rhoads \& Klein 1993).

Reforesting the treatment area would cost less and require less labor than reforesting the entire study area (10,160 saplings vs. 24,640 saplings). Though reforesting the entire area would create conditions most similar to what existed 250 years ago, the control and wetland area cannot be seen from the Great Meadows where the battle occurred. Moreover, these areas did not play important roles during the battle, and therefore, have little importance in historical interpretation (i.e., movement of troops, troop positions, etc.) (Thomas \& DeLaura 1996).

\section{Invertebrates}

Our findings suggest that, although Morrow's honeysuckle produces an abundant crop of berries (Rodewald \& Brittingham 2004; personal observation), it does not "produce" invertebrates 
(Chapter 3). The berries of bush honeysuckles are high in sugar, but relatively low in protein and nitrogen compared to other native shrubs (Witmer 1996; Witmer \& Van Soest 1998). These high sugar, low nutrient fruits may be beneficial for some specialist frugivores such as Bombycilla cedrorum (Cedar Waxwings) (Witmer 1996; but also see Witmer \& Van Soest 1998 for potential consequences to Cedar Waxwing feeding on the berries of bush honeysuckles), but we question whether the conspicuous red fruit provides quality food for the bulk of vertebrates, particularly since the shrub 1) impacts the growth and establishment of other hard- and soft-mast producing native species (e.g., Woods 1993; Hutchinson \& Vankat 1997; Medley 1997); 2) fails to act as a host plant for native herbivorous invertebrates, particularly larval leaf chewers (Chapter 3); and 3) negatively impacts invertebrate biomass in the understory by reducing herbaceous cover (Chapter 3). Our results suggest that Morrow's honeysuckle, and perhaps all exotic bush honeysuckles, may be producing wildlife "candy" that fails to meet the nutritional and caloric demands of the majority of wildlife species. Land managers have often promoted and planted exotic, fruit-producing shrubs such as Elaeagnus umbellata (autumn olive), E. angustifolia (Russian olive), and Rosa multiflora (multiflora rose); while these and other exotic plants planted for forage and food may indeed benefit some wildlife, particularly those wildlife targeted because of their recreational or economic benefit (i.e., game species), few studies have assessed the impact of these exotic "wildlife" plants on invertebrate biomass (Tallamy 2004).

Invertebrates play a vital role in assimilating and transferring energy to higher trophic levels (Wilson 1987; Kellert 1993; Tallamy 2004). Approximately $26 \%$ of all animal species are insects that feed on plants (Weis \& Berenbaum 1988). If their food plants are eliminated, many of these herbivores may also become eliminated, along with their parasitoid hosts, invertebrate predators, and vertebrate predators. And this impact may not be limited to terrestrial animals. 
For example, Utz (2005) found that terrestrial invertebrates formed the majority of the diet for Salvelinus fontinalis (brook trout) in mountain streams in West Virginia, particularly in spring, summer, and fall. He advocated that riparian zones be managed to ensure an adequate supply of terrestrial invertebrate prey for brook trout. Exotic plants, particularly Polygonum cuspidatum (Japanese knotweed), are common invaders of riparian zones in the United States, as well as other countries (Seiger 1991). In its introduced habitat, the exotic shrub has few pests and it is believed that the enemy release hypothesis is responsible for explaining its spread and persistence (Seiger 1991). If true, then the spread of Japanese knotweed could be negatively impacting insectivorous fishes such as brook trout, which rely on a diet of terrestrial vertebrates for growth and maintenance.

Overall, our results reinforce a growing view that more action needs to be performed to control existing exotic invasive species and keep new exotic invasive species from becoming established (e.g., Pimentel et al. 2000; Reichard \& White 2001). It is ironic that while new methods for controlling bush honeysuckles are being tested (e.g., Hartman \& McCarthy 2004; Chapter 2), conflicting research is being conducted to derive new varieties of the shrub (e.g., Sharp \& Belcher 1981) and control potential pests (Mahr \& Dittl 1986; Herman \& Davidson 1997). We believe that the horticultural industry should be forced to take more responsibility for its products (i.e., exotic plants) and be liable for introduced plants that begin to naturalize and become invaders. Like other industries, many nurseries cite that government restrictions will negatively affect economic growth (Reichard \& White 2001). However, we agree with Reichard and White (2001) that the combination of education, collaboration between ecologists and horticuluralists, and stricter policies regulating sales of invasive plants, are vital to decrease future plant invasions that cost an estimated $\$ 35$ billion per year (Pimentel et al. 2000). 


\section{Future Research}

\section{Morrow's honeysuckle and its relatives}

Our research has led to other questions concerning the management and ecology of Morrow's honeysuckle and its close relatives. For instance, little is known how burning effects the shrub. Fire kills the top of the shrubs, but repeated burnings need to occur to kill sprouts and keep the shrub from spreading (Nyboer 1992). Fire is thought to maintain early successional habitat and prevent the spread of shrubs such as bush honeysuckle (Laughlin 2004). However, thorough investigations of the role of fire in maintaining early successional communities invaded by bush honeysuckles have yet to be performed. For instance, how frequent should prescribed fires be set to restore and maintain early successional communities being encroached by bush honeysuckle? When is the best time to burn to decrease bush honeysuckle biomass, yet maintain native plants and shrubs?

Many researchers believe that bush honeysuckles may be allelopathic, but little conclusive research has been performed (Barnes 1972; Trisel 1997). We found herbaceous cover to be depressed under dense thickets of the shrubs, but not necessarily under single shrubs of Morrow's honeysuckle (Chapter 3). This suggests that shading, and not allelopathy, may be responsible for decreased herb cover, but more research is needed to assess whether or not the shrubs are truly allelopathic.

Because bush honeysuckles are among the first shrubs to leaf-out in the spring, it may be possible to use aerial photography or satellite imagery to map areas where the shrubs have invaded. For instance, attempts to map Liriodendron tulipifera (tulip poplar) communities in the southern Appalachians have met with some success; the trees are among the earliest species to leaf-out and have a conspicuous greenish-yellow hue in the spring (G. Kauffman 2003, United States Forest Service, Asheville, North Carolina, personal communication). While mapping the 
shrubs might not be possible in forested areas, the technique might work in abandoned fields or disturbed sites that lack a forested overstory.

We found a greater proportion of exotic herbs under dense thickets of Morrow's honeysuckle relative to the other shrub types (Chapter 2). Exotic species have been shown to impact other ecological processes (e.g., Ehrenfield 2003); these impacts may favor the establishment and growth of exotic understory species. More research is needed to ascertain why a greater proportion of plants are exotic in areas dominated by Morrow's honeysuckle.

Because of time and money constraints, most ecological studies are short term (i.e., a few years at most). We believe that it is critical to examine the long-term results of Morrow's honeysuckle removal and subsequent restoration of the study site. At our study site, honeysuckle removal is just the first of many steps that will be required to return the site to the desired ecological and historical condition (Figure 3). Monitoring these steps will provide valuable information that will aid future restoration efforts in areas invaded by bush honeysuckles.

\section{Invertebrates}

Bird fitness is often closely linked to their insect food supplies (e.g., Burke \& Nol 1998; Zanette et al. 2000). Future research should focus on the behavioral response to birds nesting in areas dominated by bush honeysuckles. How often do the birds have to forage for insects, particularly when nesting, relative to areas devoid of exotics? What types of invertebrates are consumed in areas dominated by exotics relative to more "natural" habitats? If foraging rates increase due to the fewer number of available invertebrates in a landscape matrix dominated by exotics, how is songbird fitness affected? Is nest predation higher in nests located in exotic species because the birds have to spend more time away from the nest foraging for their favorite prey items? 
Clearly, this is an issue that needs more research, especially since some of the insectivorous songbirds nesting at our site (i.e., Dendroica discolor (Prairie Warbler) and Vermivora chrysoptera (Golden-winged Warbler)) are listed as birds of conservation concern according to the United States Fish and Wildlife Service.

There should be more research to assess whether exotic plants affect invertebrate availability for small mammals and herpetofauna as well. For instance, we caught several species of small mammals within our study site, including the insectivores Sorex cinereus (masked shrew) and Blarina brevicauda (short-tailed shrew) (Edalgo 2005). Does the cover provided by the shrubs (i.e., less predation) offset the lower invertebrate biomass available to the shrews (i.e., lower reproduction rates)? What factors are driving shrew populations in areas dominated by Morrow's honeysuckle relative to more natural habitats?

Obviously more studies are needed on other exotic plants to ascertain whether the patterns we found in invertebrate abundance, biomass, and richness hold true. There is evidence that introduced plant species that are closely related to existing native plants often share the same hosts (Connor et al. 1980; Yela \& Lawton 1997). However, we did not find that pattern in our study (Chapter 3). The continued expansion of exotic invasive plants may have dire consequences on invertebrate assemblages, and ultimately higher trophic levels. Continued research of invertebrate and herbivore loads in other exotic invasive plants may help bring needed attention to the often underappreciated role of invertebrates.

\section{Acknowledgments}

This study was funded by the National Park Service and Fort Necessity National Battlefield. We thank C. Ranson for her guidance and logistical support. We thank J. Edalgo for productive 
discussions concerning the ecology of Morrow's honeysuckle and its impact on invertebrate and vertebrate communities. C. Ranson and J. McGraw reviewed earlier drafts of this work.

\section{LITERATURE CITED}

Barnes, W. J. 1972. The autoecology of the Lonicera $\times$ bella complex. Ph.D. Dissertation. University of Wisconsin, Madison.

Barnes, W. J., and G. Cottam. 1974. Some autoecological studies of the Lonicera $\times$ bella complex. Ecology 55:40-50.

Batcher, M. S., and S. A. Stiles. 2000. Element stewardship abstract for Lonicera maackii (Rupr.) Maxim (Amur honeysuckle), Lonicera morrowii A. Gray (Morrow's honeysuckle), Lonicera tatarica L. (Tatarian honeysuckle), Lonicera $\times$ bella Zabel (Bell's honeysuckle). The Nature Conservancy, Arlington, Virginia. Available from http://tncweeds.ucdavis.edu/esadocs/documnts/loni_sp.pdf (accessed October 2005).

Borgmann, K. L., and A. D. Rodewald. 2004. Nest predation in an urbanizing landscape: the role of exotic shrubs. Ecological Applications 14:1757-1765.

Buddle, C. M., S. Higgins, and A. L. Rypstra. 2004. Ground-dwelling spider assemblages inhabiting riparian forests and hedgerows in an agricultural landscape. American Midland Naturalist 151:15-26.

Burke, D. M., and E. Nol. 1998. Influence of food abundance, nest-site habitat, and forest fragmentation on breeding Ovenbirds. Auk 115:147-155.

Burnham, K. P., and D. R. Anderson. 2002. Model selection and multimodel inference: a practical information-theoretic approach. 2nd edition. Springer-Verlag, New York, New York. 
Collier, M. H., J. L. Vankat, and M. R. Hughes. 2002. Diminished plant richness and abundance below Lonicera maackii, an invasive shrub. American Midland Naturalist 147:60-71.

Connor, E. F., S. H. Faeth, D. Simberloff, and P. A. Opler. 1980. Taxonomic isolation and the accumulation of herbivorous insects: a comparison of introduced and native trees. Ecological Entomology 5:205-211.

Dirr, M. A. 1990. Manual of woody landscape plants: their identification, ornamental characteristics, culture, propagation, and uses. 4th edition. Stipes Publishing Company, Champaign, Illinois.

Edalgo, J. A. 2005. Implications for the small mammal and earthworm communities in a degraded ecosystem. MS Thesis. West Virginia University, Morgantown. Available from https://eidr.wvu.edu/etd/documentdata.eTD?documentid=4326 (accessed February 2006).

Ehrenfield, J. G. 2003. Effects of exotic plant invasions on soil nutrient cycling processes. Ecosystems 6:503-523.

Fort Necessity National Battlefield. 1991. General Management Plan/Development Concept Plan/Interpretive Prospectus. Unpublished report.

Gorchov, D. L., and D. E. Trisel. 2003. Competitive effects of the invasive shrub, Lonicera maackii (Rupr.) Herder (Caprifoliaceae), on the growth and survival of native tree seedlings. Plant Ecology 166:13-24.

Harrington, R. A., B. J. Brown, and P. B. Reich. 1989. Ecophysiology of exotic and native shrubs in southern Wisconsin: relationship of leaf characteristics, resource availability, and phenology to seasonal patterns of carbon gain. Oecologia 80:356-367. 
Hartman, K. M., and B. C. McCarthy. 2004. Restoration of a forest understory after the removal of an invasive shrub, Amur honeysuckle (Lonicera maackii). Restoration Ecology 12:154-165.

Herman, D. E., and C. G. Davidson. 1997. Evaluation of Lonicera taxa for honeysuckle aphid susceptibility, winter hardiness and use. Journal of Environmental Horticulture 15:177182.

Hutchinson, T. F., and J. L. Vankat. 1997. Invasibility and effects of Amur honeysuckle in southwestern Ohio forests. Conservation Biology 11:1117-1124.

Kellert, S. R. 1993. Values and perceptions of invertebrates. Conservation Biology 7:845-855.

Kelso, G. K. 1994. Palynology in historical rural landscape studies: the pre-clearance forest border at Great Meadows, Pennsylvania. National Park Service, Technical Report NPS/MARFONE/NRTR - 95/067.

Kopas, F. A. 1973. Soil survey of Fayette County, Pennsylvania. U.S. Department of Agriculture, Soil Conservation Service, U.S. Government Printing Office, Washington D.C.

Laughlin, D. C. 2004. Woody plant invasion and the importance of anthropogenic disturbance within xeric limestone prairies. Journal of the Pennsylvania Academy of Science 78:1228.

Love, J. P., J. A. Edalgo, and J. T. Anderson. 2006. Management plan for a degraded meadow infested with Morrow's honeysuckle: results of a comprehensive inventory of flora and fauna and the implications of management options on the ecological communities and historical landscape at Fort Necessity National Battlefield, PA. Fort Necessity National Battlefield, Pennsylvania. Unpublished report. 
Luken, J. O., and N. Goessling. 1995. Seedling distribution and potential persistence of the exotic shrub Lonicera maackii in fragmented forests. American Midland Naturalist 133:124-130.

Luken, J. O., and J. W. Thieret. 1996. Amur honeysuckle, its fall from grace. BioScience 46:1824.

Mahr, D. L., and T. G. Dittl. 1986. Chemical, natural, and cultural control of Hyadaphis tataricae (Homoptera: Aphididae) on honeysuckle. The Great Lakes Entomologist 19:91100.

Martin, A. C., H. S. Zim, and A. L. Nelson. 1951. American wildlife and plants: a guide to wildlife food habits. Dover Publications, Inc., New York, New York.

McEvoy, N. L. and R. D. Durtsche. 2004. Effect of the invasive shrub Lonicera maackii (Caprifoliaceae; Amur honeysuckle) on autumn herptofauna biodiversity. Journal of the Kentucky Academy of Science 65:27-32.

Medley, K. E. 1997. Distribution of the non-native shrub Lonicera maackii in Kramer Woods, Ohio. Physical Geography 18:18-36.

Nyboer, R. 1992. Vegetation management guideline: bush honeysuckles - tatarian, Morrow's, Belle, and Amur honeysuckle (Lonicera tatarica L., L. morrowii Gray, L. x bella Zabel, and L. maackii [Rupr.] Maxim.). Natural Areas Journal 12:218-219.

Pimentel, D., L. Lach, R. Zuniga, and D. Morrison. 2000. Environmental and economic costs of nonindigenous species in the United States. BioScience 50:53-65.

Ranson, C. 2003. Environmental assessment: Great Meadows Cultural Landscape Rehabilitation Project, Fort Necessity National Battlefield. Unpublished report. Fort Necessity National Battlefield, Farmington, Pennsylvania. 
Rasband, W. S. 2005. ImageJ. U.S. National Institute of Health, Bethesda, Maryland. Software available from http://rsb.info.nih.gov/ij/ (accessed December 2005).

Rehder, A. 1940. A manual of cultivated trees and shrubs. 2nd edition. MacMillan Publishing Company, New York, New York.

Reichard, S. H., and P. White. 2001. Horticulture as a pathway of invasive plant introductions in the United States. BioScience 51:103-113.

Rhoads, A. F., and W. M. Klein, Jr. 1993. The vascular flora of Pennsylvania: annotated checklist and atlas. American Philosophical Society, Philadelphia, Pennsylvania.

Ripley, T. H., R. A. Cookingham, and R. P. Corrinet. 1957. Black locust for quail in Massachusetts. Journal of Wildlife Management 21:459.

Rodewald, P. G., and M. C. Brittingham. 2004. Stopover habitats of landbirds during fall: use of edge-dominated and early successional forests. Auk 121:1040-1055.

Schmidt, K. A., and C. J. Whelan. 1999. Effects of exotic Lonicera and Rhamnus on songbird nest predation. Conservation Biology 13:1502-1506.

Seiger, L. 1991. Element stewardship abstract for Polygonum cuspidatum (Japanese knotweed, Mexican bamboo). The Nature Conservancy, Arlington, Virginia. Available from http://ncweeds.ucdavis.edu/esadocs/documnts/polycus.html (accessed February 2006).

Sharp, W. C., and C. R. Belcher. 1981. 'Rem-Red' Amur honeysuckle - a multipurpose landscape shrub. American Nurseryman 153:7, 94-95.

Sosebee, R. E. 1983. Physiological, phenological, and environment considerations in brush and weed control. Pages 27-44 in Proceedings of the brush management symposium, Albuquerque, NM, 16 February 1983. Texas Tech Press, Lubbock. 
Strausbaugh, P. D. and E. L. Core. 1977. Flora of West Virginia. 2nd edition. Seneca Books, Inc., Morgantown, West Virginia.

Tallamy, D. M. 2004. Do alien plants reduce insect biomass? Conservation Biology 18:16891692.

Thomas, T. and M. DeLaura. 1996. Fort Necessity National Battlefield Historic Resource Study. US Dept. of the Interior, National Park Service, Denver Service Center, Colorado.

Trisel, D. E., and D. L. Gorchov. 1994. Regional distribution, ecological impact, and leaf phenology of the invasive shrub, Lonicera maackii. Bulletin of the Ecological Society of America 75(Supplement):231-232.

Trisel, D. E. 1997. The invasive shrub, Lonicera maackii (Rupr.) Herder (Caprifoliaceae): factors contributing to its success and its effect on native species. PhD. Dissertation. Miami University, Oxford, Ohio.

Utz, R. M. 2005. Temporal trends in consumption, growth, and successful feeding traits of a central Appalachian brook trout population at the watershed scale. MS Thesis, West Virginia University, Morgantown. Available from https://eidr.wvu.edu/etd/documentdata.eTD?documentid=4327 (accessed February 2006). VanDruff, L. W., E. G. Bolen, and G. J. San Julian. 1996. Management of urban wildlife. Pages 507-530 in T. A. Bookhout, editor. Research and management techniques for wildlife and habitats, 5th edition. The Wildlife Society. Allen Press, Inc., Lawrence, Kansas.

Vose, J. M. 2000. Perspectives on using prescribed fire to achieve desired ecosystem conditions. Pages 12-17 in W. K. Moser and C. F. Moser, editors. Fire and forest ecology: innovative silviculture and vegetation management. Tall Timbers Fire Ecology Conference Proceedings, No. 21. Tall Timbers Research Station, Tallahassee, Florida. 
Wade, G. L. 1985. Success of trees and shrubs in an 18-year old planting on mine soil. U.S. Forest Service, Northeastern Forest Experiment Station, Broomall, Pennsylvania.

Weis, A. E., and M. R. Berenbaum. 1988. Herbivorous insects and green plants. Pages 123-162 in W. G. Abrahamson, editor. Plant-animal interactions: a textbook. McGraw-Hill, New York, New York.

Western Pennsylvania Conservancy. 2003. Plant community mapping and surveys for species of special concern at Allegheny Portage Railroad National Historic Site, Johnstown Flood National Memorial, Fort Necessity National Battlefield, and Friendship Hill National Historic Site. Unpublished report.

Wilson, E. O. 1987. The little things that run the world (the importance and conservation of invertebrates). Conservation Biology 1:344-346.

Witmer, M. C. 1996. Consequences of an alien shrub on the plumage coloration and ecology of Cedar Waxwings. Auk 113:735-743.

Witmer, M. C., and P. J. Van Soest. 1998. Contrasting digestive strategies of fruit-eating birds. Functional Ecology 12:728-741.

Woods, K. D. 1993. Effects of invasion by Lonicera tatarica L. on herbs and tree seedlings in four New England forests. American Midland Naturalist 130:62-74.

Yela, J. L., and J. H. Lawton. 1997. Insect herbivore loads on native and introduced plants: a preliminary study. Entomologia Experimentalis et Applicata 85:275-279.

Yemm, E. W., and A. J. Willis. 1954. The estimation of carbohydrates in plant extracts by anthrone. Biochemical Journal 57:508-514.

Zanette, L., P. Doyle, and S. M. Trémont. 2000. Food shortage in small fragments: evidence from an area-sensitive passerine. Ecology 81:1654-1666. 


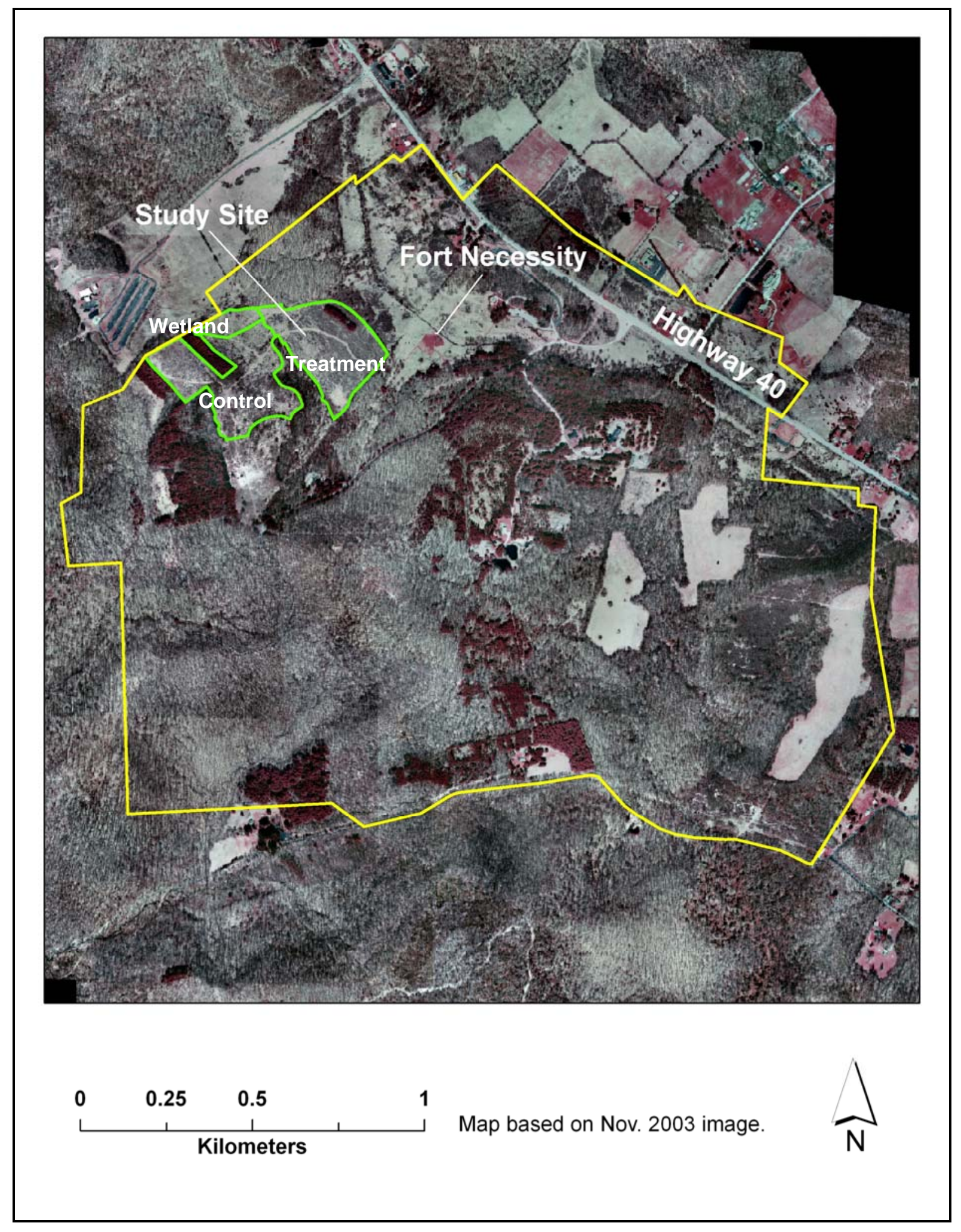

Figure 1. The "wetland" and "control" areas should be managed as quality early successional habitat, while the "treatment" area should be managed to facilitate the growth of a mature forest. 


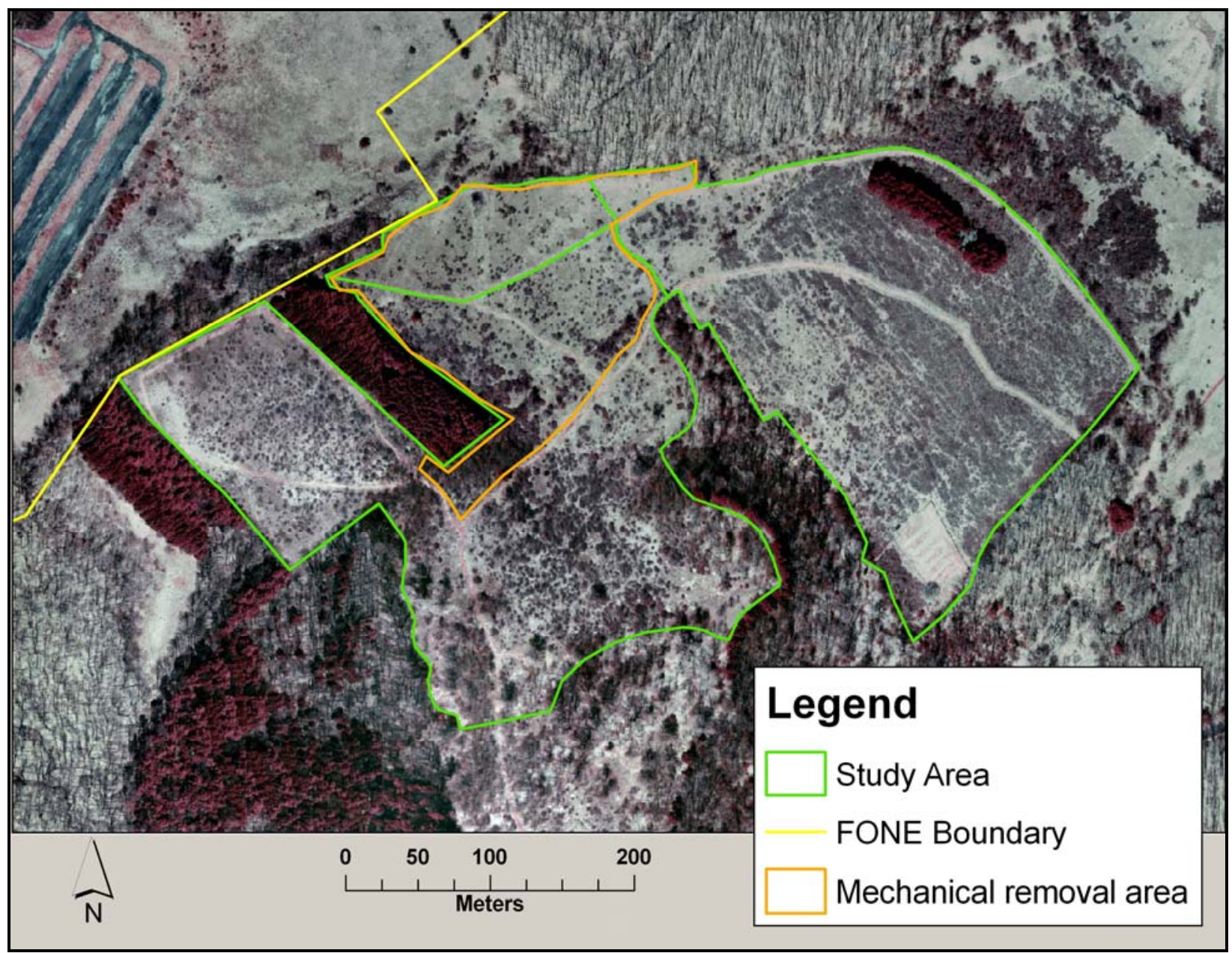

Figure 2. Approximately 2.75 ha of thinly scattered Morrow's honeysuckle should be treated by mechanically removing the shrubs. The study area outside the mechanical removal area should be treated with a foliar application of glyphosate in October, followed by bush-hogging in May. 


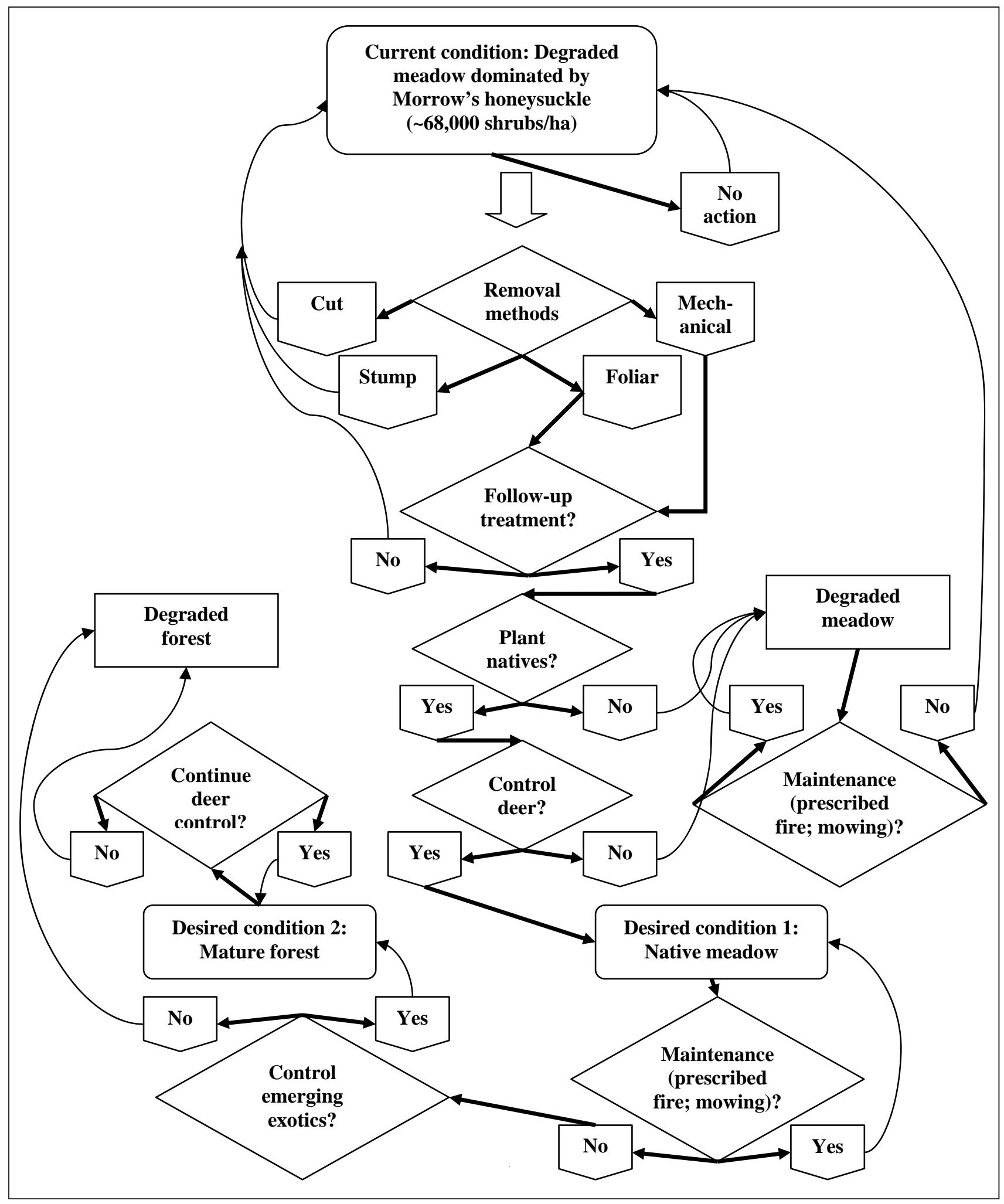

Figure 3. Conceptual pathway to achieve desired conditions in a degraded meadow dominated by Morrow's honeysuckle at Fort Necessity National Battlefield, Pennsylvania, U.S.A. 


\section{APPENDICES}

Appendix Ia. Results for the tests for homogeneity of slope for covariates (pre-treatment shrub metrics) versus the dependent variables (post-treatment shrub metrics) prior to running analysis of covariance for Morrow's honeysuckle and native shrubs at Fort Necessity National Battlefield, Pennsylvania, U.S.A.

Tests for homogeneity of slope for covariates (pre-treatment metrics) versus the dependent variable (post-treatment metrics) were evaluated prior to running analysis of covariance (PROC GLM, SAS version 9.1). For shrub cover, we found no significant difference in the post-treatment and pre-treatment relationship as a function of season $\left(\mathrm{F}_{[1,41]}=0.82, p=\right.$ 0.371), treatment method $\left(\mathrm{F}_{[4,35]}=1.48, p=0.230\right)$, or treatment method-season $\left(\mathrm{F}_{[8,26]}=1.67\right.$, $p=0.154)$. We also tested the homogeneity of slope for Morrow's honeysuckle stem density data and found no significant difference in the post-treatment and pre-treatment relationship as a function of season $\left(\mathrm{F}_{[1,41]}=0.08, p=0.777\right)$, treatment method $\left(\mathrm{F}_{[4,35]}=0.86, \mathrm{p}=0.499\right)$, or treatment method-season $\left(\mathrm{F}_{[9,25]}=1.18, p=0.351\right)$. We tested the homogeneity of slope for Morrow's honeysuckle shrub density and found no significant difference in the post-treatment and pre-treatment relationship as a function of season $\left(\mathrm{F}_{[1,41]}=0.68, p=0.414\right)$, treatment method $\left(\mathrm{F}_{[4,35]}=1.90, p=0.132\right)$, or treatment method-season $\left(\mathrm{F}_{[9,25]}=0.93, p=0.520\right)$. We

also tested the homogeneity of slope for native shrub density and found no significant difference in the post- and pre-treatment relationship as a function of treatment method $\left(\mathrm{F}_{[4,35]}=0.22, p=\right.$ $0.925)$ or treatment method-season $\left(\mathrm{F}_{[9,25]}=1.11, p=0.394\right)$, though there was a significant difference as a function of season $\left(\mathrm{F}_{[1,35]}=5.41, p=0.025\right)$. 
Appendix IIa. Number of Morrow's honeysuckle root samples per phenological stage and their mean $( \pm$ SE) percent total nonstructural carbohydrates levels at Fort Necessity National Battlefield, Pennsylvania, U.S.A. from March 2004 - February 2005.

\begin{tabular}{llrc}
\hline Phenological stage & \multicolumn{1}{c}{ Month $(s)$} & $n$ & $\bar{X} \pm S E^{*}$ \\
\hline Leaf senescence & October & 5 & $33.07 \pm 1.74 \% \mathrm{~A}$ \\
Fruiting & June - September & 19 & $26.08 \pm 1.23 \% \mathrm{~B}$ \\
Leaf abscission & November & 5 & $24.83 \pm 0.37 \% \mathrm{BC}$ \\
Bud break & April & 5 & $22.52 \pm 1.34 \% \mathrm{BC}$ \\
Dormant & December - March & 19 & $21.03 \pm 0.83 \% \mathrm{CD}$ \\
Fully leaved, flowering & May & 5 & $17.67 \pm 1.47 \% \mathrm{D}$ \\
\hline
\end{tabular}

* Means with different letters are significantly different $(p<0.05)$, based on Duncan's multiple range tests. 
Appendix IIIa. Morrow's honeysuckle and F and $p$ values for pre- and post-treatment cover, stem density, shrub density, and native shrub density at Fort Necessity National Battlefield, Pennsylvania, U.S.A.

\begin{tabular}{|c|c|c|c|c|c|c|}
\hline \multirow[b]{3}{*}{ Dependent variables } & \multicolumn{6}{|c|}{ Independent variables } \\
\hline & \multicolumn{2}{|c|}{ Season } & \multicolumn{2}{|c|}{ Treatment } & \multicolumn{2}{|c|}{ Season $\times$ treatment } \\
\hline & $F$ & $\mathrm{p}$ & $F$ & $\mathrm{p}$ & $F$ & $\mathrm{p}$ \\
\hline \multicolumn{7}{|l|}{ Pre-treatment } \\
\hline Cover & 10.20 & 0.003 & 0.88 & 0.488 & 1.00 & 0.421 \\
\hline Stem density & 1.39 & 0.247 & 0.64 & 0.640 & 1.39 & 0.257 \\
\hline Shrub density & 4.10 & 0.051 & 0.95 & 0.445 & 1.78 & 0.155 \\
\hline Native shrub density & 0.23 & 0.631 & 0.15 & 0.961 & 1.42 & 0.248 \\
\hline \multicolumn{7}{|l|}{ Post-treatment } \\
\hline Cover & 12.07 & $<0.001$ & 27.65 & $<0.001$ & 4.21 & 0.007 \\
\hline Stem density & 47.30 & $<0.001$ & 23.69 & $<0.001$ & 7.13 & $<0.001$ \\
\hline Shrub density & 20.87 & $<0.001$ & 19.68 & $<0.001$ & 5.21 & 0.002 \\
\hline Native shrub density & 1.19 & 0.296 & 1.43 & 0.284 & 2.19 & 0.132 \\
\hline
\end{tabular}


Appendix IVa. Morrow's honeysuckle $t$ and $p$ values for pre- and post-treatment cover, stem density, shrub density, and native shrub density comparisons (paired t-tests) at Fort Necessity National Battlefield, Pennsylvania, U.S.A.

\begin{tabular}{|c|c|c|c|c|c|c|c|c|c|}
\hline \multirow[b]{2}{*}{ Variables } & \multirow[b]{2}{*}{$d f$} & \multicolumn{2}{|c|}{ Cover } & \multicolumn{2}{|c|}{ Stem density } & \multicolumn{2}{|c|}{ Shrub density } & \multicolumn{2}{|c|}{ Native shrub density } \\
\hline & & $t$ & $\mathrm{p}$ & $t$ & $\mathrm{p}$ & $t$ & $\mathrm{p}$ & $t$ & $\mathrm{p}$ \\
\hline \multicolumn{10}{|l|}{ Season } \\
\hline$\overline{\text { Spring }}$ & 22 & 8.12 & $<0.001$ & 3.28 & 0.003 & 5.77 & $<0.001$ & 0.56 & 0.583 \\
\hline Autumn & 21 & 5.87 & $<0.001$ & -2.49 & 0.021 & 3.57 & 0.002 & 1.67 & 0.111 \\
\hline \multicolumn{10}{|l|}{ Treatment } \\
\hline Control & 4 & -2.16 & 0.097 & -6.17 & 0.004 & -3.13 & 0.035 & -2.14 & 0.091 \\
\hline Cut & 9 & 3.86 & 0.004 & -2.55 & 0.031 & 2.94 & 0.016 & -0.57 & 0.585 \\
\hline Foliar & 9 & 7.57 & $<0.001$ & 3.54 & 0.006 & 9.37 & $<0.001$ & 1.65 & 0.134 \\
\hline Mechanical & 9 & 11.60 & $<0.001$ & 2.81 & 0.020 & 3.50 & 0.007 & 0.91 & 0.386 \\
\hline Stump & 9 & 8.39 & $<0.001$ & -1.55 & 0.156 & 4.14 & 0.003 & 2.80 & 0.021 \\
\hline
\end{tabular}


Appendix Va. Mean ( \pm SE) Morrow's honeysuckle cover, stem density, shrub density, and native shrub density per $5 \times 5$-m plot differed between pre- and post-treatment at Fort Necessity National Battlefield, Pennsylvania, U.S.A.

\begin{tabular}{|c|c|c|c|c|c|c|c|}
\hline \multirow[b]{3}{*}{ Season-Treatment } & \multirow[b]{3}{*}{$n$} & \multicolumn{3}{|c|}{ Morrow's honeysuckle cover ${ }^{1}$} & \multicolumn{3}{|c|}{ Morrow's honeysuckle stem density } \\
\hline & & Pre & Post & & Pre & Post & \\
\hline & & $\bar{X} \pm S E$ & $\bar{X} \pm S E$ & $\% \Delta^{2}$ & $\bar{X} \pm S E$ & $\bar{X} \pm S E$ & $\% \Delta$ \\
\hline Spring-Control & 3 & $0.77 \pm 0.06 \mathrm{~A}$ & $0.84 \pm 0.06 \mathrm{~B}$ & $+9.1 \%$ & $325 \pm 52 \mathrm{~A}$ & $444 \pm 79 \mathrm{~B}$ & $+36.6 \%$ \\
\hline Autumn-Control & 2 & $0.95 \pm 0.00 \mathrm{~A}$ & $1.00 \pm 0.00 \mathrm{~A}$ & $+5.3 \%$ & $422 \pm 135 \mathrm{~A}$ & $528 \pm 104 \mathrm{~B}$ & $+25.1 \%$ \\
\hline Spring-Cut & 5 & $0.85 \pm 0.04 \mathrm{~A}$ & $0.05 \pm 0.01 \mathrm{EF}$ & $-94.1 \%$ & $415 \pm 46 \mathrm{~A}$ & $422 \pm 56 \mathrm{~B}$ & $+1.7 \%$ \\
\hline Autumn-Cut & 5 & $0.85 \pm 0.06 \mathrm{~A}$ & $0.48 \pm 0.14 \mathrm{C}$ & $-43.5 \%$ & $451 \pm 73 \mathrm{~A}$ & $1,503 \pm 180 \mathrm{~A}$ & $+233.3 \%$ \\
\hline Spring-Foliar & 5 & $0.70 \pm 0.12 \mathrm{~A}$ & $0.17 \pm 0.06 \mathrm{DE}$ & $-75.7 \%$ & $395 \pm 90 \mathrm{~A}$ & $200 \pm 64 \mathrm{C}$ & $-49.4 \%$ \\
\hline Autumn-Foliar & 5 & $0.96 \pm 0.02 \mathrm{~A}$ & $0.04 \pm 0.01 \mathrm{EF}$ & $-95.8 \%$ & $594 \pm 70 \mathrm{~A}$ & $368 \pm 96 \mathrm{BC}$ & $-38.0 \%$ \\
\hline Spring-Mechanical & 5 & $0.76 \pm 0.02 \mathrm{~A}$ & $0.01 \pm 0.01 \mathrm{~F}$ & $-98.7 \%$ & $462 \pm 101 \mathrm{~A}$ & $33 \pm 9 \mathrm{D}$ & $-92.9 \%$ \\
\hline Autumn-Mechanical & 5 & $0.84 \pm 0.06 \mathrm{~A}$ & $0.05 \pm 0.01 \mathrm{EF}$ & $-94.0 \%$ & $334 \pm 48 \mathrm{~A}$ & $366 \pm 90 \mathrm{BC}$ & $+9.6 \%$ \\
\hline Spring-Stump & 5 & $0.75 \pm 0.06 \mathrm{~A}$ & $0.04 \pm 0.02 \mathrm{EF}$ & $-94.7 \%$ & $438 \pm 80 \mathrm{~A}$ & $390 \pm 184 \mathrm{BC}$ & $-11.0 \%$ \\
\hline Autumn-Stump & 5 & $0.85 \pm 0.04 \mathrm{~A}$ & $0.41 \pm 0.08 \mathrm{CD}$ & $-51.8 \%$ & $521 \pm 79 \mathrm{~A}$ & $2,302 \pm 210 \mathrm{~A}$ & $+341.8 \%$ \\
\hline
\end{tabular}


Appendix Va. Continued.

\begin{tabular}{|c|c|c|c|c|c|c|c|}
\hline \multirow[b]{3}{*}{ Season-treatment } & \multirow[b]{3}{*}{$n$} & \multicolumn{3}{|c|}{ Morrow's honeysuckle shrub density } & \multicolumn{3}{|c|}{ Native shrub density } \\
\hline & & Pre & Post & & Pre & Post & \\
\hline & & $\bar{X} \pm S E$ & $\bar{X} \pm S E$ & $\% \Delta$ & $\bar{X} \pm S E$ & $\bar{X} \pm S E$ & $\% \Delta$ \\
\hline Spring-Control & 3 & $125 \pm 32 \mathrm{~A}$ & $151 \pm 30 \mathrm{AB}$ & $+20.8 \%$ & $16.7 \pm 7.1 \mathrm{~A}$ & $42.7 \pm 10.2 \mathrm{~A}$ & $+155.7 \%$ \\
\hline Autumn-Control & 2 & $192 \pm 51 \mathrm{~A}$ & $211 \pm 32 \mathrm{~A}$ & $+9.9 \%$ & $28.0 \pm 23.0 \mathrm{~A}$ & $28.5 \pm 16.5 \mathrm{ABC}$ & $+1.8 \%$ \\
\hline Spring-Cut & 5 & $153 \pm 20 \mathrm{~A}$ & $92 \pm 8 \mathrm{CD}$ & $-39.9 \%$ & $20.4 \pm 2.7 \mathrm{~A}$ & $29.8 \pm 9.6 \mathrm{AB}$ & $+46.1 \%$ \\
\hline Autumn-Cut & 5 & $174 \pm 39 \mathrm{~A}$ & $150 \pm 24 \mathrm{AB}$ & $-13.8 \%$ & $28.8 \pm 6.5 \mathrm{~A}$ & $22.6 \pm 3.2 \mathrm{ABC}$ & $-21.5 \%$ \\
\hline Spring-Foliar & 5 & $146 \pm 36 \mathrm{~A}$ & $49 \pm 17 \mathrm{E}$ & $-66.4 \%$ & $19.0 \pm 4.8 \mathrm{~A}$ & $8.2 \pm 1.0 \mathrm{C}$ & $-56.8 \%$ \\
\hline Autumn-Foliar & 5 & $272 \pm 26 \mathrm{~A}$ & $85 \pm 12 \mathrm{D}$ & $-68.8 \%$ & $22.2 \pm 7.7 \mathrm{~A}$ & $21.0 \pm 6.5 \mathrm{BC}$ & $-5.4 \%$ \\
\hline Spring-Mechanical & 5 & $161 \pm 33 \mathrm{~A}$ & $14 \pm 4 \mathrm{~F}$ & $-91.3 \%$ & $37.8 \pm 10.3 \mathrm{~A}$ & $23.4 \pm 5.3 \mathrm{ABC}$ & $-38.1 \%$ \\
\hline Autumn-Mechanical & 5 & $125 \pm 23 \mathrm{~A}$ & $95 \pm 17 \mathrm{CD}$ & $-24.0 \%$ & $13.6 \pm 3.3 \mathrm{~A}$ & $16.2 \pm 4.4 \mathrm{BC}$ & $+19.1 \%$ \\
\hline Spring-Stump & 5 & $146 \pm 29 \mathrm{~A}$ & $77 \pm 32 \mathrm{DE}$ & $-47.3 \%$ & $25.2 \pm 8.1 \mathrm{~A}$ & $16.0 \pm 2.6 \mathrm{BC}$ & $-36.5 \%$ \\
\hline Autumn-Stump & 5 & $199 \pm 39 \mathrm{~A}$ & $141 \pm 22 \mathrm{BC}$ & $-29.1 \%$ & $22.0 \pm 6.1 \mathrm{~A}$ & $10.0 \pm 2.4 \mathrm{BC}$ & $-54.5 \%$ \\
\hline
\end{tabular}


Appendix VIa. The majority of Morrow's honeysuckle post-treatment live stems were classified as sprouts at Fort Necessity National Battlefield, Pennsylvania, U.S.A. during the 2005 field season.

\begin{tabular}{lccccc}
\hline Season-Treatment & $n$ & Mean no. sprouts & Mean no. non-sprouts & Total & $\%$ Sprouts \\
\hline Spring-Control & 3 & 0.0 & 444.0 & 444.0 & $0.0 \%$ \\
Autumn-Control & 2 & 0.0 & 552.5 & 552.5 & $0.0 \%$ \\
Spring-Cut & 5 & 418.8 & 3.6 & 422.4 & $99.0 \%$ \\
Autumn-Cut & 5 & $1,501.2$ & 1.4 & $1,502.6$ & $99.9 \%$ \\
Spring-Foliar & 5 & 157.0 & 43.0 & 200.0 & $73.6 \%$ \\
Autumn-Foliar & 5 & 324.4 & 43.4 & 367.8 & $86.6 \%$ \\
Spring-Mechanical & 5 & 32.2 & 0.4 & 32.6 & $98.7 \%$ \\
Autumn-Mechanical & 5 & 346.0 & 0.2 & 346.2 & $100.0 \%$ \\
Spring-Stump & 5 & 386.0 & 4.0 & 390.0 & $99.2 \%$ \\
Autumn-Stump & 5 & $2,299.4$ & 2.2 & $2,301.6$ & $99.9 \%$ \\
\hline
\end{tabular}


Appendix VIIa. We identified, recorded frequency, determined mean $( \pm \mathrm{SE})$ number of live stems and plants per plot, estimated mean $( \pm$ SE) number of live stems and plants per hectare, and determined mean $( \pm$ SE) basal diameter of live stems of 21 woody species within $455 \times 5$-m plots prior to testing Morrow’s honeysuckle removal methods at Fort Necessity National Battlefield, Pennsylvania, U.S.A. Bold-faced species are exotic.

\begin{tabular}{|c|c|c|c|c|c|c|}
\hline & & Stems/plot & Stems/ha & Shrubs/plot & Shrubs/ha & Diameter $(\mathrm{mm})$ \\
\hline Species & Frequency & $\bar{X} \pm S E$ & $\bar{X} \pm S E$ & $\bar{X} \pm S E$ & $\bar{X} \pm S E$ & $\bar{X} \pm S E$ \\
\hline $\begin{array}{l}\text { Acer rubrum } \\
\text { Red maple }\end{array}$ & 45 & $8.5 \pm 0.9$ & $3,400 \pm 1,960$ & $7.8 \pm 0.9$ & $3,120 \pm 360$ & $1.72 \pm 0.11$ \\
\hline $\begin{array}{l}\text { Acer saccharum } \\
\text { Sugar maple }\end{array}$ & 2 & $1.0 \pm 0.0$ & 18 & $1.0 \pm 0.0$ & 18 & $2.50 \pm 0.11$ \\
\hline $\begin{array}{l}\text { Amelanchier arborea } \\
\text { Serviceberry }\end{array}$ & 9 & $3.6 \pm 1.3$ & $288 \pm 104$ & $2.8 \pm 1.3$ & $224 \pm 104$ & $3.37 \pm 0.38$ \\
\hline $\begin{array}{l}\text { Berberis thunbergii } \\
\text { Japanese barberry }\end{array}$ & 3 & $2.0 \pm 0.0$ & 53 & $1.7 \pm 0.3$ & $45 \pm 8$ & $2.00 \pm 0.07$ \\
\hline $\begin{array}{l}\text { Cornus racemosa } \\
\text { Gray dogwood }\end{array}$ & 5 & $7.0 \pm 4.1$ & $311 \pm 182$ & $4.2 \pm 1.9$ & $187 \pm 84.4$ & $3.02 \pm 0.21$ \\
\hline $\begin{array}{l}\text { Crataegus pruinosa } \\
\text { Waxyfruit hawthorne }\end{array}$ & 32 & $5.4 \pm 0.7$ & $1,536 \pm 199$ & $4.8 \pm 0.6$ & $1,365 \pm 171$ & $5.31 \pm 0.58$ \\
\hline $\begin{array}{l}\text { Fraxinus americana } \\
\text { White ash }\end{array}$ & 1 & 1.0 & 11 & 1.0 & 11 & 2.00 \\
\hline $\begin{array}{l}\text { Liriodendron tulipifera } \\
\text { Tulip poplar }\end{array}$ & 6 & $1.2 \pm 0.2$ & $64 \pm 11$ & $1.2 \pm 0.2$ & $64 \pm 11$ & $1.83 \pm 0.15$ \\
\hline
\end{tabular}


Appendix VIIa. Continued.

\begin{tabular}{|c|c|c|c|c|c|c|}
\hline & & Stems/plot & Stems/ha & Shrubs/plot & Shrubs/ha & Diameter $(\mathrm{mm})$ \\
\hline Species & Frequency & $\bar{X} \pm S E$ & $\bar{X} \pm S E$ & $\bar{X} \pm S E$ & $\bar{X} \pm S E$ & $\bar{X} \pm S E$ \\
\hline $\begin{array}{l}\text { Lonicera morrowii } \\
\text { Morrow's honeysuckle }\end{array}$ & 45 & $441.5 \pm 24.9$ & $176,600 \pm 9,960$ & $169.8 \pm 11.2$ & $67,920 \pm 4,480$ & $7.49 \pm 0.15$ \\
\hline $\begin{array}{l}\text { Malus coronaria } \\
\text { Sweet crabapple }\end{array}$ & 20 & $4.1 \pm 0.9$ & $729 \pm 160$ & $3.7 \pm 0.8$ & $658 \pm 142$ & $6.08 \pm 0.62$ \\
\hline $\begin{array}{l}\text { Nyssa sylvatica } \\
\text { Black gum }\end{array}$ & 1 & 4.0 & 36 & 4.0 & 36 & 1.00 \\
\hline $\begin{array}{l}\text { Prunus serotina } \\
\text { Black cherry }\end{array}$ & 39 & $4.2 \pm 0.6$ & $1,456 \pm 208$ & $3.9 \pm 0.5$ & $1,352 \pm 173$ & $1.63 \pm 0.10$ \\
\hline $\begin{array}{l}\text { Quercus alba } \\
\text { White oak }\end{array}$ & 8 & $1.8 \pm 0.6$ & $128 \pm 43$ & $1.5 \pm 0.5$ & $107 \pm 36$ & $2.31 \pm 0.22$ \\
\hline $\begin{array}{l}\text { Quercus rubra } \\
\text { Northern red oak }\end{array}$ & 1 & 1.0 & 9 & 1.0 & 9 & 2.00 \\
\hline $\begin{array}{l}\text { Rhus copallinum } \\
\text { Winged sumac }\end{array}$ & 1 & 2.0 & 18 & 2.0 & 18 & 6.50 \\
\hline $\begin{array}{l}\text { Robinia pseudoacacia } \\
\text { Black locust }\end{array}$ & 2 & $3.0 \pm 1.0$ & $53 \pm 18$ & $3.0 \pm 1.0$ & $53 \pm 18$ & $30.13 \pm 4.72$ \\
\hline $\begin{array}{l}\text { Rosa multiflora } \\
\text { Multiflora rose }\end{array}$ & 14 & $6.0 \pm 2.3$ & $747 \pm 286$ & $2.1 \pm 0.5$ & $261 \pm 62$ & $6.24 \pm 0.47$ \\
\hline $\begin{array}{l}\text { Sassafras albidum } \\
\text { Sassafras }\end{array}$ & 1 & 1.0 & 9 & 1.0 & 9 & 8.00 \\
\hline
\end{tabular}


Appendix VIIa. Continued.

\begin{tabular}{lcccccc}
\hline & & Stems/plot & Stems/ha & Shrubs/plot & Shrubs/ha & Diameter (mm) \\
\cline { 2 - 6 } Species & Frequency & $\bar{X} \pm S E$ & $\bar{X} \pm S E$ & $\bar{X} \pm S E$ & $\bar{X} \pm S E$ & $\bar{X} \pm S E$ \\
\hline $\begin{array}{l}\text { Viburnum lentago } \\
\text { Nannyberry }\end{array}$ & 1 & 7.0 & 62 & 6.0 & 53 & 11.86 \\
$\begin{array}{l}\text { Viburnum recognitum } \\
\text { Southern arrowwood }\end{array}$ & 33 & $10.9 \pm 2.0$ & $3,197 \pm 587$ & $6.5 \pm 1.3$ & $1,907 \pm 381$ & $5.04 \pm 0.49$ \\
$\begin{array}{l}\text { Vitis aestivalis } \\
\text { Summer grape }\end{array}$ & 5 & $1.0 \pm 0.0$ & $44 \pm 0.0$ & $1.0 \pm 0.0$ & $44 \pm 0.0$ & $2.60 \pm 0.23$ \\
\hline
\end{tabular}


Appendix VIIIa. After Morrow’s honeysuckle removal methods were completed, we identified, determined frequency, mean ( \pm SE)

number of live stems and plants per plot, and mean $( \pm \mathrm{SE})$ number of live stems and plants per hectare for each season-treatment combination during the summer 2005 at Fort Necessity National Battlefield, Pennsylvania, U.S.A. Bold-faced species are exotic.

\begin{tabular}{|c|c|c|c|c|c|c|c|}
\hline & & & & Stems/plot & Stems/ha & Shrubs/plot & Shrubs/ha \\
\hline \multirow{9}{*}{$\begin{array}{l}\text { Season-Treatment } \\
\text { Autumn-Control }\end{array}$} & $n$ & Species & Frequency & $\bar{X} \pm S E$ & $\bar{X} \pm S E$ & $\bar{X} \pm S E$ & $\bar{X} \pm S E$ \\
\hline & 2 & $\begin{array}{l}\text { Acer rubrum } \\
\text { Red maple }\end{array}$ & 2 & $9.5 \pm 6.5$ & $3,800 \pm 2,600$ & $9.5 \pm 6.5$ & $3,800 \pm 2,600$ \\
\hline & & $\begin{array}{l}\text { Amelanchier arborea } \\
\text { Serviceberry }\end{array}$ & 1 & 1.0 & 200 & 1.0 & 200 \\
\hline & & $\begin{array}{l}\text { Berberis thunbergii } \\
\text { Japanese barberry }\end{array}$ & 1 & 1.0 & 200 & 1.0 & 200 \\
\hline & & $\begin{array}{l}\text { Crataegus pruinosa } \\
\text { Waxyfruit hawthorne }\end{array}$ & 1 & 8.0 & 1,600 & 5.0 & 1000 \\
\hline & & $\begin{array}{l}\text { Elaeagnus umbellata } \\
\text { Autumn olive }\end{array}$ & 1 & 1.0 & 200 & 1.0 & 200 \\
\hline & & $\begin{array}{l}\text { Lonicera morrowii } \\
\text { Morrow's } \\
\text { honeysuckle }\end{array}$ & 2 & $527.5 \pm 103.5$ & $\begin{array}{c}211,000 \pm \\
41,400\end{array}$ & $211.0 \pm 32.0$ & $84,400 \pm 12,800$ \\
\hline & & $\begin{array}{l}\text { Malus coronaria } \\
\text { Sweet crabapple }\end{array}$ & 2 & $1.5 \pm 0.5$ & $600 \pm 200$ & $1.5 \pm 0.5$ & $600 \pm 200$ \\
\hline & & $\begin{array}{l}\text { Prunus serotina } \\
\text { Black cherry }\end{array}$ & 2 & $1.0 \pm 0.0$ & $400 \pm 0$ & $1.0 \pm 0.0$ & $400 \pm 0$ \\
\hline
\end{tabular}


Appendix VIIIa. Continued.

\begin{tabular}{|c|c|c|c|c|c|c|c|}
\hline & & & & Stems/plot & Stems/ha & Shrubs/plot & Shrubs/ha \\
\hline Season-Treatment & $n$ & Species & Frequency & $\bar{X} \pm S E$ & $\bar{X} \pm S E$ & $\bar{X} \pm S E$ & $\bar{X} \pm S E$ \\
\hline \multirow[t]{2}{*}{$\frac{\text { Autumn-Control }}{\text { (continued) }}$} & 2 & $\begin{array}{l}\text { Quercus rubra } \\
\text { Northern red oak }\end{array}$ & 1 & 1.0 & 200 & 1.0 & 200 \\
\hline & & $\begin{array}{l}\text { Viburnum recognitum } \\
\text { Southern arrowwood }\end{array}$ & 2 & $11.5 \pm 10.5$ & $4,600 \pm 4,200$ & $9.0 \pm 8.0$ & $3,600 \pm 3,200$ \\
\hline \multirow{6}{*}{ Spring-Control } & & $\begin{array}{l}\text { Amelanchier arborea } \\
\text { Serviceberry }\end{array}$ & 2 & $2.0 \pm 0.8$ & $533 \pm 213$ & $1.5 \pm 0.5$ & $400 \pm 133$ \\
\hline & & $\begin{array}{l}\text { Crataegus pruinosa } \\
\text { Waxyfruit hawthorne }\end{array}$ & 3 & $3.3 \pm 1.9$ & $1,320 \pm 760$ & $2.3 \pm 0.9$ & $920 \pm 360$ \\
\hline & & $\begin{array}{l}\text { Malus coronaria } \\
\text { Sweet crabapple }\end{array}$ & 3 & $2.0 \pm 0.6$ & $800 \pm 240$ & $2.0 \pm 0.6$ & $800 \pm 240$ \\
\hline & & $\begin{array}{l}\text { Nyssa sylvatica } \\
\text { Black gum }\end{array}$ & 1 & 1.0 & 133 & 1.0 & 133 \\
\hline & & $\begin{array}{l}\text { Prunus serotina } \\
\text { Black cherry }\end{array}$ & 3 & $5.3 \pm 1.3$ & $2,120 \pm 520$ & $5.3 \pm 1.3$ & $2,120 \pm 520$ \\
\hline & & $\begin{array}{l}\text { Quercus alba } \\
\text { White oak }\end{array}$ & 1 & 1.0 & 133 & 1.0 & 133 \\
\hline
\end{tabular}


Appendix VIIIa. Continued.

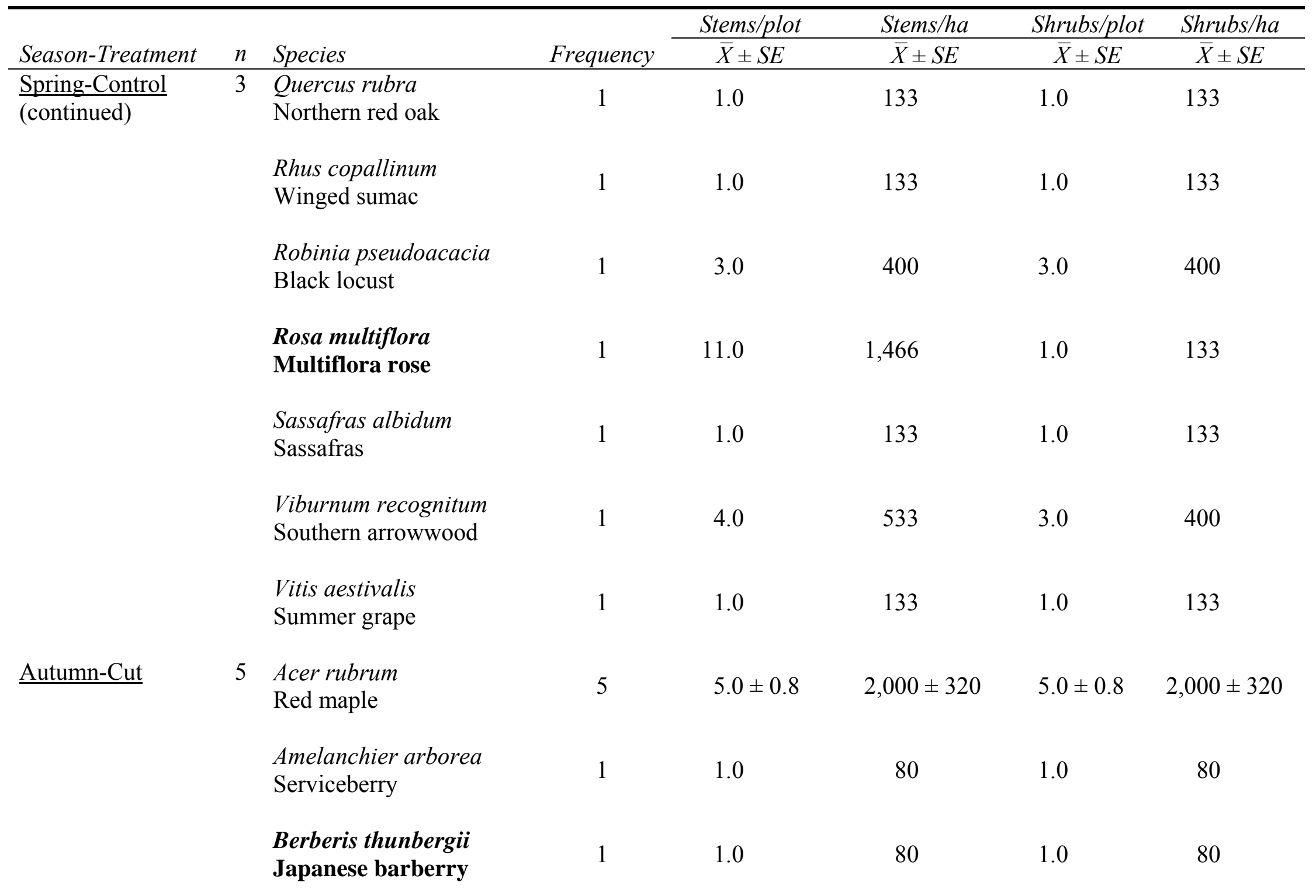


Appendix VIIIa. Continued.

\begin{tabular}{|c|c|c|c|c|c|c|c|}
\hline & & & & Stems/plot & Stems $/ h a$ & $\frac{\text { Shrubs/plot }}{\bar{V}}$ & Shrubs/ha \\
\hline Season-Treatment & $n$ & Species & Frequency & $\bar{X} \pm S E$ & $\bar{X} \pm S E$ & & \\
\hline \multirow[t]{10}{*}{$\frac{\text { Autumn-Cut }}{\text { (continued) }}$} & 5 & $\begin{array}{l}\text { Crataegus pruinosa } \\
\text { Waxyfruit hawthorne }\end{array}$ & 3 & $1.7 \pm 0.3$ & $408 \pm 72$ & $1.7 \pm 0.3$ & $408 \pm 72$ \\
\hline & & $\begin{array}{l}\text { Liriodendron tulipifera } \\
\text { Tulip poplar }\end{array}$ & 2 & $1.0 \pm 0.0$ & $160 \pm 0.0$ & 1.0 & $160 \pm 0.0$ \\
\hline & & $\begin{array}{l}\text { Lonicera morrowii } \\
\text { Morrow's honeysuckle }\end{array}$ & 5 & $1,502.6 \pm 179.6$ & $\begin{array}{c}601,040 \pm \\
71,840\end{array}$ & $150.4 \pm 23.5$ & $60,160 \pm 9,400$ \\
\hline & & $\begin{array}{l}\text { Malus coronaria } \\
\text { Sweet crabapple }\end{array}$ & 5 & $6.4 \pm 1.4$ & $2,560 \pm 440$ & $6.0 \pm 1.3$ & $2,400 \pm 520$ \\
\hline & & $\begin{array}{l}\text { Prunus serotina } \\
\text { Black cherry }\end{array}$ & 5 & $4.2 \pm 1.1$ & $1,680 \pm 440$ & $3.0 \pm 0.9$ & $1,200 \pm 360$ \\
\hline & & $\begin{array}{l}\text { Quercus alba } \\
\text { White oak }\end{array}$ & 1 & 1.0 & 80 & 1.0 & 80 \\
\hline & & $\begin{array}{l}\text { Rosa multiflora } \\
\text { Multiflora rose }\end{array}$ & 3 & $4.3 \pm 2.2$ & $2,040 \pm 528$ & $4.3 \pm 2.8$ & $2,040 \pm 672$ \\
\hline & & $\begin{array}{l}\text { Viburnum recognitum } \\
\text { Southern arrowwood }\end{array}$ & 4 & $8.5 \pm 5.3$ & $2,720 \pm 1,696$ & $6.0 \pm 3.8$ & $1,920 \pm 1,216$ \\
\hline & & $\begin{array}{l}\text { Viburnum lentago } \\
\text { Nannyberry }\end{array}$ & 1 & 8.0 & 640 & 7.0 & 560 \\
\hline & & $\begin{array}{l}\text { Vitis aestivalis } \\
\text { Summer grape }\end{array}$ & 1 & 1.0 & 80 & 1.0 & 80 \\
\hline
\end{tabular}


Appendix VIIIa. Continued.

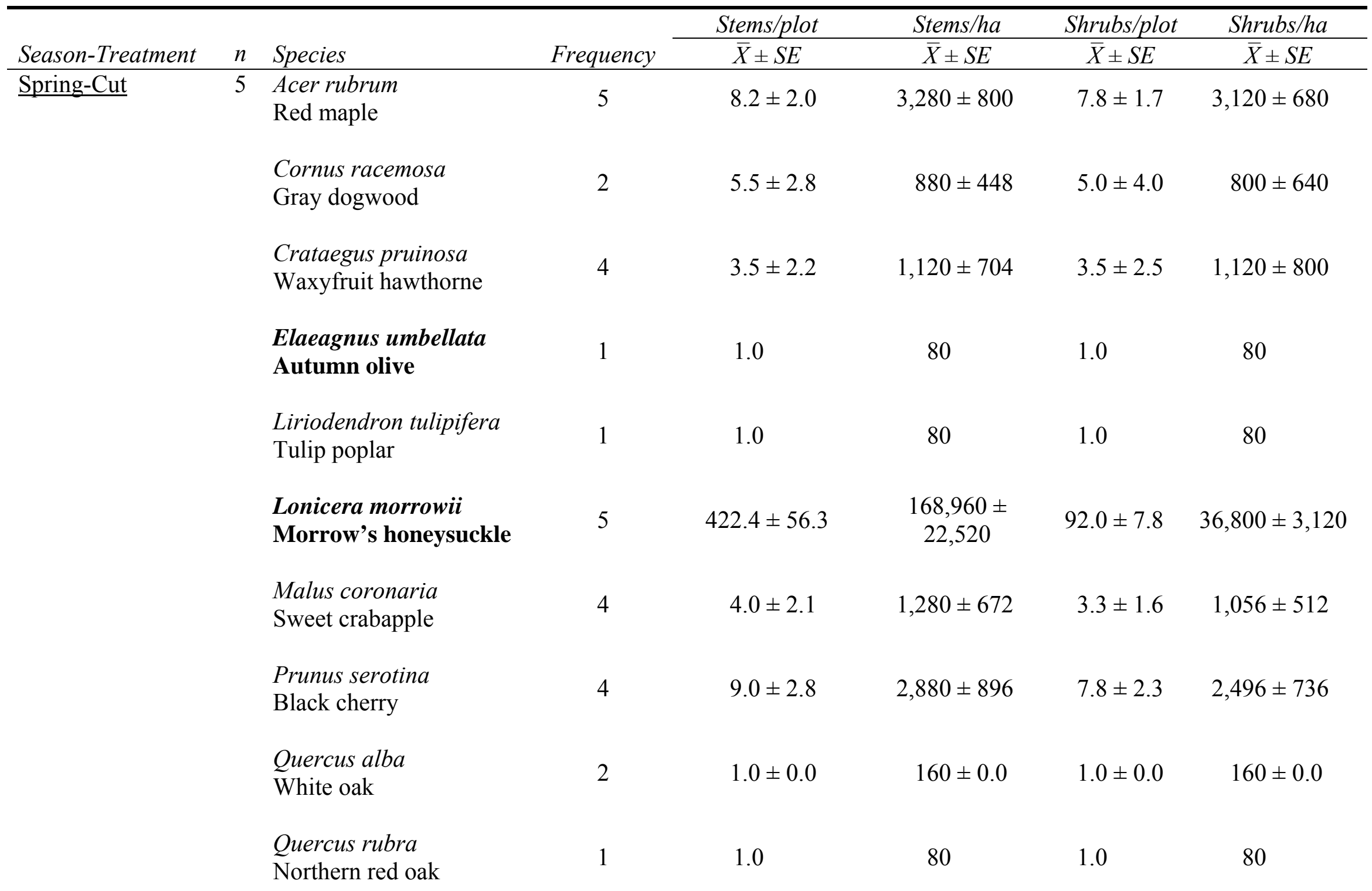


Appendix VIIIa. Continued.

\begin{tabular}{|c|c|c|c|c|c|c|c|}
\hline & & & & Stems/plot & Stems/ha & Shrubs/plot & Shrubs/ha \\
\hline Season-Treatment & $n$ & Species & Frequency & $\bar{X} \pm S E$ & $\bar{X} \pm S E$ & $\bar{X} \pm S E$ & $\bar{X} \pm S E$ \\
\hline \multirow[t]{3}{*}{$\frac{\text { Spring-Cut }}{\text { (continued) }}$} & 5 & $\begin{array}{l}\text { Rhus copallinum } \\
\text { Winged sumac }\end{array}$ & 1 & 40.0 & 3,200 & 22.0 & 1,760 \\
\hline & & $\begin{array}{l}\text { Robinia pseudoacacia } \\
\text { Black locust }\end{array}$ & 1 & 7.0 & 560 & 7.0 & 560 \\
\hline & & $\begin{array}{l}\text { Viburnum recognitum } \\
\text { Southern arrowwood }\end{array}$ & 3 & $6.0 \pm 3.9$ & $1,440 \pm 936$ & $3.3 \pm 2.3$ & $792 \pm 552$ \\
\hline \multirow[t]{5}{*}{$\underline{\text { Autumn-Foliar }}$} & 5 & $\begin{array}{l}\text { Acer rubrum } \\
\text { Red maple }\end{array}$ & 3 & $2.0 \pm 0.4$ & $480 \pm 96$ & $2.0 \pm 0.6$ & $480 \pm 144$ \\
\hline & & $\begin{array}{l}\text { Crataegus pruinosa } \\
\text { Waxyfruit hawthorne }\end{array}$ & 1 & 5.0 & 400 & 5.0 & 400 \\
\hline & & $\begin{array}{l}\text { Liriodendron tulipifera } \\
\text { Tulip poplar }\end{array}$ & 1 & 2.0 & 160 & 2.0 & 160 \\
\hline & & $\begin{array}{l}\text { Lonicera morrowii } \\
\text { Morrow's honeysuckle }\end{array}$ & 5 & $367.8 \pm 96.3$ & $\begin{array}{c}147,120 \pm \\
38,520\end{array}$ & $85.0 \pm 12.4$ & $\begin{array}{l}34,000 \pm \\
4,960\end{array}$ \\
\hline & & $\begin{array}{l}\text { Malus coronaria } \\
\text { Sweet crabapple }\end{array}$ & 3 & $2.7 \pm 1.3$ & $648 \pm 312$ & $2.7 \pm 1.7$ & $648 \pm 408$ \\
\hline
\end{tabular}


Appendix VIIIa. Continued.

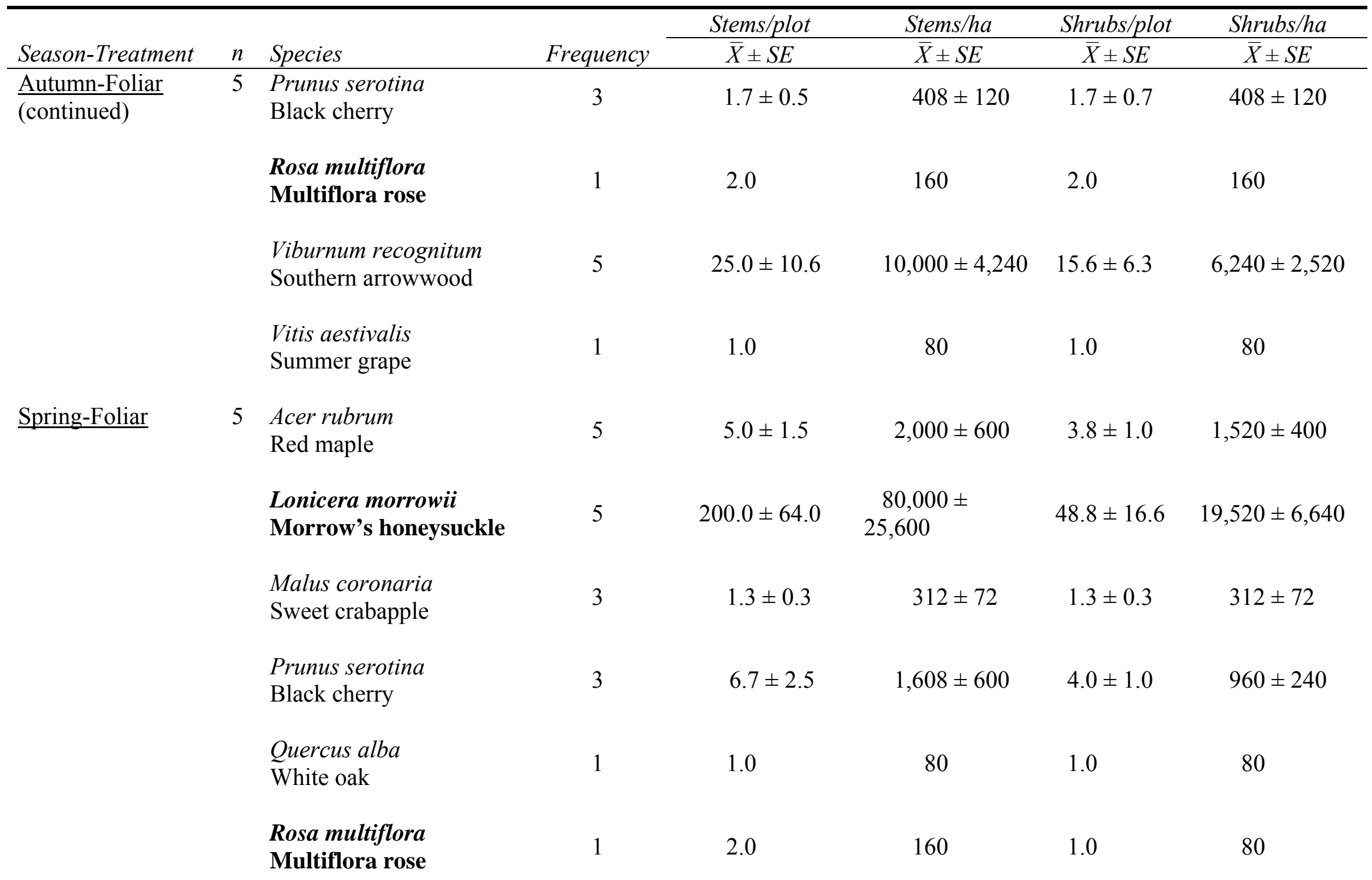


Appendix VIIIa. Continued.

\begin{tabular}{|c|c|c|c|c|c|c|c|}
\hline & & & & Stems/plot & Stems/ha & Shrubs/plot & Shrubs/ha \\
\hline Season-Treatment & $n$ & Species & Frequency & $\bar{X} \pm S E$ & $\bar{X} \pm S E$ & $\bar{X} \pm S E$ & $\bar{X} \pm S E$ \\
\hline \multirow[t]{3}{*}{$\frac{\text { Spring-Foliar }}{\text { (continued) }}$} & 5 & $\begin{array}{l}\text { Sassafras albidum } \\
\text { Sassafras }\end{array}$ & 1 & 1.0 & 80 & 1.0 & 80 \\
\hline & & $\begin{array}{l}\text { Viburnum recognitum } \\
\text { Southern arrowwood }\end{array}$ & 2 & $9.5 \pm 5.4$ & $1,520 \pm 864$ & $2.0 \pm 1.0$ & $320 \pm 160$ \\
\hline & & $\begin{array}{l}\text { Vitis aestivalis } \\
\text { Summer grape }\end{array}$ & 1 & 1.0 & 80 & 1.0 & 80 \\
\hline \multirow[t]{7}{*}{$\underline{\text { Autumn-Mechanical }}$} & 5 & $\begin{array}{l}\text { Acer rubrum } \\
\text { Red maple }\end{array}$ & 4 & $4.5 \pm 1.7$ & $1,440 \pm 544$ & $4.5 \pm 1.7$ & $1,440 \pm 544$ \\
\hline & & $\begin{array}{l}\text { Amelanchier arborea } \\
\text { Serviceberry }\end{array}$ & 1 & 2.0 & 160 & 1.0 & 80 \\
\hline & & $\begin{array}{l}\text { Crataegus pruinosa } \\
\text { Waxyfruit hawthorne }\end{array}$ & 3 & $1.3 \pm 0.3$ & $312 \pm 72$ & $1.3 \pm 0.3$ & $312 \pm 72$ \\
\hline & & $\begin{array}{l}\text { Fraxinus americana } \\
\text { White ash }\end{array}$ & 2 & $1.0 \pm 0.0$ & $160 \pm 0.0$ & $1.0 \pm 0.0$ & $160 \pm 0$ \\
\hline & & $\begin{array}{l}\text { Lonicera morrowii } \\
\text { Morrow's honeysuckle }\end{array}$ & 5 & $365.8 \pm 90.3$ & $\begin{array}{c}146,320 \pm \\
36,120\end{array}$ & $95.4 \pm 17.4$ & $\begin{array}{l}38,160 \pm \\
6,960\end{array}$ \\
\hline & & $\begin{array}{l}\text { Malus coronaria } \\
\text { Sweet crabapple }\end{array}$ & 5 & $6.2 \pm 1.8$ & $2,480 \pm 720$ & $4.6 \pm 1.4$ & $1,840 \pm 560$ \\
\hline & & $\begin{array}{l}\text { Prunus serotina } \\
\text { Black cherry }\end{array}$ & 3 & $6.7 \pm 4.0$ & $1,608 \pm 960$ & $6.7 \pm 5.2$ & $1,608 \pm 1,248$ \\
\hline
\end{tabular}


Appendix VIIIa. Continued.

\begin{tabular}{|c|c|c|c|c|c|c|c|}
\hline & & & & Stems/plot & Stems/ha & Shrubs/plot & Shrubs/ha \\
\hline Season-Treatment & $n$ & Species & Frequency & $\bar{X} \pm S E$ & $\bar{X} \pm S E$ & $\bar{X} \pm S E$ & $\bar{X} \pm S E$ \\
\hline \multirow[t]{4}{*}{$\begin{array}{l}\text { Autumn-Mechanical } \\
\text { (continued) }\end{array}$} & 5 & $\begin{array}{l}\text { Quercus rubra } \\
\text { Northern red oak }\end{array}$ & 1 & 1.0 & 80 & 1.0 & 80 \\
\hline & & $\begin{array}{l}\text { Rosa multiflora } \\
\text { Multiflora rose }\end{array}$ & 1 & 1.0 & 80 & 1.0 & 80 \\
\hline & & $\begin{array}{l}\text { Viburnum recognitum } \\
\text { Southern arrowwood }\end{array}$ & 3 & $3.0 \pm 0.8$ & $720 \pm 192$ & $2.7 \pm 0.9$ & $648 \pm 216$ \\
\hline & & $\begin{array}{l}\text { Vitis aestivalis } \\
\text { Summer grape }\end{array}$ & 3 & $1.0 \pm 0.0$ & $240 \pm 0$ & $1.0 \pm 0.0$ & $240 \pm 0$ \\
\hline \multirow[t]{6}{*}{ Spring-Mechanical } & 5 & $\begin{array}{l}\text { Acer rubrum } \\
\text { Red maple }\end{array}$ & 4 & $5.3 \pm 2.4$ & $1,696 \pm 768$ & $4.8 \pm 2.3$ & $1,536 \pm 736$ \\
\hline & & $\begin{array}{l}\text { Amelanchier arborea } \\
\text { Serviceberry }\end{array}$ & 2 & $1.0 \pm 0.0$ & 160 & 1.0 & 160 \\
\hline & & $\begin{array}{l}\text { Crataegus pruinosa } \\
\text { Waxyfruit hawthorne }\end{array}$ & 3 & $1.7 \pm 0.5$ & $408 \pm 120$ & $1.7 \pm 0.7$ & $408 \pm 168$ \\
\hline & & $\begin{array}{l}\text { Liriodendron tulipifera } \\
\text { Tulip poplar }\end{array}$ & 2 & $1.0 \pm 0.0$ & $180 \pm 0.0$ & $1.0 \pm 0.0$ & $180 \pm 0.0$ \\
\hline & & $\begin{array}{l}\text { Lonicera morrowii } \\
\text { Morrow's honeysuckle }\end{array}$ & 5 & $32.6 \pm 8.7$ & $13,040 \pm 3,480$ & $14.2 \pm 3.9$ & $5,680 \pm 1,560$ \\
\hline & & $\begin{array}{l}\text { Malus coronaria } \\
\text { Sweet crabapple }\end{array}$ & 4 & $9.0 \pm 2.1$ & $2,880 \pm 672$ & $7.0 \pm 0.7$ & $2,240 \pm 224$ \\
\hline
\end{tabular}


Appendix VIIIa. Continued.

\begin{tabular}{|c|c|c|c|c|c|c|c|}
\hline & $n$ & & Биосания & $\frac{\text { Stems/plot }}{\bar{V}}$ & $\begin{array}{l}\text { Stems } / h a \\
\bar{V}\end{array}$ & $\frac{\text { Shrubs/plot }}{\bar{V}}$ & $\begin{array}{c}\text { Shrubs/ha } \\
\overline{\bar{V}}+{ }^{\prime} E\end{array}$ \\
\hline \multirow{8}{*}{$\begin{array}{l}\text { Spring-Mechanical } \\
\text { (continued) }\end{array}$} & $\frac{n}{5}$ & Specles & Frequency & $\Lambda \pm \mathrm{D} L$ & $\Lambda \pm \mathrm{D} L$ & $X \pm \mathrm{SE}$ & $X \pm \mathrm{SE}$ \\
\hline & 5 & $\begin{array}{l}\text { Prunus serotina } \\
\text { Black cherry }\end{array}$ & 5 & $5.8 \pm 1.5$ & $2,320 \pm 600$ & $4.8 \pm 1.5$ & $1,920 \pm 600$ \\
\hline & & $\begin{array}{l}\text { Quercus alba } \\
\text { White oak }\end{array}$ & 2 & $2.0 \pm 0.6$ & $320 \pm 96$ & $2.0 \pm 1.0$ & $320 \pm 160$ \\
\hline & & $\begin{array}{l}\text { Rhus copallinum } \\
\text { Winged sumac }\end{array}$ & 1 & 11.0 & 880 & 9.0 & 720 \\
\hline & & $\begin{array}{l}\text { Robinia pseudoacacia } \\
\text { Black locust }\end{array}$ & 2 & $3.5 \pm 1.6$ & $560 \pm 256$ & $3.0 \pm 2.0$ & $480 \pm 320$ \\
\hline & & $\begin{array}{l}\text { Rosa multiflora } \\
\text { Multiflora rose }\end{array}$ & 2 & $5.0 \pm 0.0$ & $800 \pm 0$ & $1.0 \pm 0.0$ & $160 \pm 0$ \\
\hline & & $\begin{array}{l}\text { Viburnum recognitum } \\
\text { Southern arrowwood }\end{array}$ & 5 & $6.6 \pm 2.2$ & $2,640 \pm 880$ & $3.0 \pm 0.9$ & $1,200 \pm 360$ \\
\hline & & $\begin{array}{l}\text { Vitis aestivalis } \\
\text { Summer grape }\end{array}$ & 1 & 3.0 & 240 & 3.0 & 240 \\
\hline \multirow[t]{3}{*}{ Autumn-Stump } & 5 & $\begin{array}{l}\text { Acer rubrum } \\
\text { Red maple }\end{array}$ & 5 & $1.8 \pm 0.5$ & $720 \pm 200$ & $1.8 \pm 0.5$ & $720 \pm 200$ \\
\hline & & $\begin{array}{l}\text { Ailanthus altissima } \\
\text { Tree of heaven }\end{array}$ & 1 & 1.0 & 80 & 1.0 & 80 \\
\hline & & $\begin{array}{l}\text { Amelanchier arborea } \\
\text { Serviceberry }\end{array}$ & 1 & 6.0 & 480 & 2.0 & 160 \\
\hline
\end{tabular}


Appendix VIIIa. Continued.

\begin{tabular}{|c|c|c|c|c|c|c|c|}
\hline & & & & Stems/plot & Stems/ha & Shrubs/plot & Shrubs/ha \\
\hline Season-Treatment & $n$ & Species & Frequency & $\bar{X} \pm S E$ & $\bar{X} \pm S E$ & $\bar{X} \pm S E$ & $\bar{X} \pm S E$ \\
\hline \multirow[t]{7}{*}{$\frac{\text { Autumn-Stump }}{\text { (continued) }}$} & 5 & $\begin{array}{l}\text { Berberis thunbergii } \\
\text { Japanese barberry }\end{array}$ & 1 & 1.0 & 80 & 1.0 & 80 \\
\hline & & $\begin{array}{l}\text { Crataegus pruinosa } \\
\text { Waxyfruit hawthorne }\end{array}$ & 2 & $2.5 \pm 0.9$ & $400 \pm 144$ & $2.5 \pm 1.5$ & $400 \pm 240$ \\
\hline & & $\begin{array}{l}\text { Malus coronaria } \\
\text { Sweet crabapple }\end{array}$ & 3 & $2.3 \pm 0.7$ & $552 \pm 168$ & $2.0 \pm 1.0$ & $480 \pm 240$ \\
\hline & & $\begin{array}{l}\text { Prunus serotina } \\
\text { Black cherry }\end{array}$ & 4 & $3.0 \pm 0.6$ & $960 \pm 192$ & $2.8 \pm 0.5$ & $896 \pm 160$ \\
\hline & & $\begin{array}{l}\text { Rosa multiflora } \\
\text { Multiflora rose }\end{array}$ & 1 & 42.0 & 3,360 & 3.0 & 240 \\
\hline & & $\begin{array}{l}\text { Viburnum recognitum } \\
\text { Southern arrowwood }\end{array}$ & 2 & $6.5 \pm 0.3$ & $1,040 \pm 48$ & $4.5 \pm 0.5$ & $720 \pm 80$ \\
\hline & & $\begin{array}{l}\text { Vitis aestivalis } \\
\text { Summer grape }\end{array}$ & 3 & $4.0 \pm 1.5$ & $960 \pm 360$ & $2.0 \pm 0.0$ & $480 \pm 0$ \\
\hline Spring-Stump & 5 & $\begin{array}{l}\text { Acer rubrum } \\
\text { Red maple }\end{array}$ & 5 & $5.2 \pm 1.1$ & $2,080 \pm 440$ & $5.0 \pm 0.9$ & $2,000 \pm 360$ \\
\hline
\end{tabular}


Appendix VIIIa. Continued.

\begin{tabular}{|c|c|c|c|c|c|c|c|}
\hline & & & & Stems/plot & Stems/ha & Shrubs/plot & Shrubs/ha \\
\hline Season-Treatment & $n$ & Species & Frequency & $\bar{X} \pm S E$ & $\bar{X} \pm S E$ & $\bar{X} \pm S E$ & $\bar{X} \pm S E$ \\
\hline \multirow[t]{8}{*}{$\frac{\text { Spring-Stump }}{\text { (continued) }}$} & 5 & $\begin{array}{l}\text { Amelanchier arborea } \\
\text { Serviceberry }\end{array}$ & 1 & 1.0 & 80 & 1.0 & 80 \\
\hline & & $\begin{array}{l}\text { Cornus racemosa } \\
\text { Gray dogwood }\end{array}$ & 1 & 7.0 & 560 & 5.0 & 400 \\
\hline & & $\begin{array}{l}\text { Liriodendron tulipifera } \\
\text { Tulip poplar }\end{array}$ & 1 & 1.0 & 80 & 1.0 & 80 \\
\hline & & $\begin{array}{l}\text { Lonicera morrowii } \\
\text { Morrow's honeysuckle }\end{array}$ & 5 & $390.0 \pm 184.0$ & $\begin{array}{l}156,000 \pm \\
73,600\end{array}$ & $77.2 \pm 32.0$ & $\begin{array}{l}30,880 \pm \\
12,800\end{array}$ \\
\hline & & $\begin{array}{l}\text { Prunus serotina } \\
\text { Black cherry }\end{array}$ & 3 & $3.3 \pm 0.5$ & $792 \pm 120$ & $3.0 \pm 0.6$ & $720 \pm 144$ \\
\hline & & $\begin{array}{l}\text { Quercus alba } \\
\text { White oak }\end{array}$ & 3 & $2.0 \pm 0.4$ & $480 \pm 96$ & $1.7 \pm 0.7$ & $408 \pm 168$ \\
\hline & & $\begin{array}{l}\text { Quercus rubra } \\
\text { Northern red oak }\end{array}$ & 1 & 1.0 & 80 & 1.0 & 80 \\
\hline & & $\begin{array}{l}\text { Rosa multiflora } \\
\text { Multiflora rose }\end{array}$ & 2 & $12.0 \pm 5.1$ & $1,920 \pm 816$ & $1.0 \pm 0$ & $800 \pm 0$ \\
\hline
\end{tabular}


Appendix VIIIa. Continued.

\begin{tabular}{|c|c|c|c|c|c|c|c|}
\hline & & & & Stems/plot & Stems/ha & Shrubs/plot & Shrubs/ha \\
\hline Season-Treatment & $n$ & Species & Frequency & $\bar{X} \pm S E$ & $\bar{X} \pm S E$ & $\bar{X} \pm S E$ & $\bar{X} \pm S E$ \\
\hline \multirow[t]{2}{*}{$\frac{\text { Spring-Stump }}{\text { (continued) }}$} & 5 & $\begin{array}{l}\text { Viburnum recognitum } \\
\text { Southern arrowwood }\end{array}$ & 3 & $14.5 \pm 6.5$ & $3,480 \pm 1,560$ & $3.3 \pm 0.9$ & $792 \pm 216$ \\
\hline & & $\begin{array}{l}\text { Vitis aestivalis } \\
\text { Summer grape }\end{array}$ & 1 & 2.0 & 160 & 2.0 & 160 \\
\hline
\end{tabular}


Appendix IXa. Following treatment, Morrow's honeysuckle still accounted for a large proportion of all live stems within a degraded meadow at Fort Necessity National Battlefield, Pennsylvania, U.S.A. in 2005.

\begin{tabular}{|c|c|c|c|c|c|c|}
\hline & & Native stems & Exotic stems & & & \\
\hline Season-Treatment & $n$ & $\bar{X} \pm S E$ & $\bar{X} \pm S E$ & $\%$ Native & $\%$ Exotic & $\begin{array}{l}\text { \% Morrow's } \\
\text { honeysuckle }\end{array}$ \\
\hline Autumn-Control & 2 & $28.5 \pm 20.5$ & $528.5 \pm 102.5$ & $5.1 \%$ & $94.9 \%$ & $94.7 \%$ \\
\hline Spring-Control & 3 & $44.7 \pm 10.2$ & $447.7 \pm 79.7$ & $9.1 \%$ & $90.9 \%$ & $90.2 \%$ \\
\hline Autumn-Cut & 5 & $26.0 \pm 5.0$ & $1,505.4 \pm 179.0$ & $1.7 \%$ & $98.3 \%$ & $98.1 \%$ \\
\hline Spring-Cut & 5 & $37.4 \pm 14.8$ & $427.4 \pm 56.3$ & $8.0 \%$ & $92.0 \%$ & $90.9 \%$ \\
\hline Autumn-Foliar & 5 & $30.4 \pm 10.7$ & $368.4 \pm 96.3$ & $7.6 \%$ & $92.4 \%$ & $92.2 \%$ \\
\hline Spring-Foliar & 5 & $14.2 \pm 4.7$ & $200.4 \pm 63.8$ & $6.6 \%$ & $93.4 \%$ & $93.2 \%$ \\
\hline Autumn-Mechanical & 5 & $18.0 \pm 4.4$ & $366.0 \pm 90.3$ & $4.7 \%$ & $95.3 \%$ & $95.3 \%$ \\
\hline Spring-Mechanical & 5 & $30.6 \pm 6.2$ & $34.6 \pm 7.9$ & $46.9 \%$ & $53.1 \%$ & $50.0 \%$ \\
\hline Autumn-Stump & 5 & $13.0 \pm 4.7$ & $2,310.4 \pm 210.2$ & $0.6 \%$ & $99.4 \%$ & $99.1 \%$ \\
\hline Spring-Stump & 5 & $26.6 \pm 7.8$ & $394.8 \pm 183.5$ & $6.3 \%$ & $93.7 \%$ & $92.5 \%$ \\
\hline
\end{tabular}


Appendix Xa. F and $p$ values for herbaceous variables prior to and following the removal of Morrows honeysuckle at Fort Necessity National Battlefield, Pennsylvania, U.S.A.

\begin{tabular}{|c|c|c|c|c|c|c|}
\hline \multirow[b]{3}{*}{ Dependent variables } & \multicolumn{6}{|c|}{ Independent variables } \\
\hline & \multicolumn{2}{|c|}{ Season } & \multicolumn{2}{|c|}{ Treatment } & \multicolumn{2}{|c|}{ Season $\times$ treatment } \\
\hline & $F$ & $\mathrm{p}$ & $F$ & $\mathrm{p}$ & $F$ & $\mathrm{p}$ \\
\hline \multicolumn{7}{|l|}{ Pre-treatment } \\
\hline Total cover & 1.55 & 0.221 & 0.38 & 0.823 & 0.50 & 0.734 \\
\hline Native cover & 1.47 & 0.233 & 1.33 & 0.278 & 0.23 & 0.917 \\
\hline Exotic cover & 0.76 & 0.390 & 0.05 & 0.995 & 1.98 & 0.120 \\
\hline Total richness & 8.33 & 0.007 & 0.29 & 0.883 & 0.73 & 0.580 \\
\hline Native richness & 2.04 & 0.162 & 0.41 & 0.798 & 0.53 & 0.711 \\
\hline Exotic richness & 12.78 & 0.001 & 0.35 & 0.845 & 0.75 & 0.568 \\
\hline Diversity $\left(H^{\prime}\right)$ & 7.61 & 0.009 & 0.97 & 0.439 & 1.30 & 0.288 \\
\hline Evenness $\left(J^{\prime}\right)$ & 1.47 & 0.234 & 0.64 & 0.634 & 0.88 & 0.488 \\
\hline Mean C & 0.01 & 0.923 & 0.49 & 0.743 & 0.88 & 0.484 \\
\hline FQI & 0.85 & 0.364 & 0.69 & 0.602 & 0.70 & 0.600 \\
\hline \multicolumn{7}{|l|}{$\underline{\text { Post-treatment }}$} \\
\hline Total cover & 15.46 & $<0.001$ & 27.82 & $<0.001$ & 1.02 & 0.410 \\
\hline Native cover & 40.88 & $<0.001$ & 6.76 & $<0.001$ & 0.86 & 0.500 \\
\hline Exotic cover & 1.19 & 0.282 & 27.86 & $<0.001$ & 10.23 & $<0.001$ \\
\hline Total richness & 17.37 & $<0.001$ & 18.71 & $<0.001$ & 0.13 & 0.971 \\
\hline Native richness & 27.17 & $<0.001$ & 11.71 & $<0.001$ & 1.15 & 0.351 \\
\hline Exotic richness & 2.09 & 0.157 & 15.28 & $<0.001$ & 1.63 & 0.188 \\
\hline Diversity $\left(H^{\prime}\right)$ & 28.26 & $<0.001$ & 12.25 & $<0.001$ & 1.55 & 0.209 \\
\hline Evenness $\left(J^{\prime}\right)$ & 17.23 & $<0.001$ & 6.39 & $<0.001$ & 2.21 & 0.087 \\
\hline Mean C & 0.66 & 0.423 & 0.86 & 0.497 & 1.36 & 0.268 \\
\hline FQI & 25.43 & $<0.001$ & 13.47 & $<0.001$ & 2.71 & 0.046 \\
\hline
\end{tabular}


Appendix XIa. T and $p$ values for pre- and post-treatment herbaceous community quality comparisons (paired t-tests) at Fort

Necessity National Battlefield, Pennsylvania, U.S.A.

\begin{tabular}{|c|c|c|c|c|c|c|c|c|c|c|c|}
\hline \multirow[b]{2}{*}{ Variable } & \multirow[b]{2}{*}{$d f$} & \multicolumn{2}{|c|}{ Total cover } & \multicolumn{2}{|c|}{ Native cover } & \multicolumn{2}{|c|}{ Exotic cover } & \multicolumn{2}{|c|}{ Total richness } & \multicolumn{2}{|c|}{ Native richness } \\
\hline & & $t$ & $\mathrm{p}$ & $t$ & $\mathrm{p}$ & $t$ & $\mathrm{p}$ & $t$ & $\mathrm{p}$ & $t$ & $\mathrm{p}$ \\
\hline \multicolumn{12}{|l|}{ Season } \\
\hline Spring & 22 & -4.84 & $<0.001$ & -5.75 & $<0.001$ & -2.83 & 0.010 & -5.80 & $<0.001$ & -5.33 & $<0.001$ \\
\hline Fall & 21 & -0.78 & 0.444 & 2.41 & 0.025 & -1.09 & 0.288 & 0.92 & 0.370 & 1.29 & 0.212 \\
\hline \multicolumn{12}{|l|}{ Treatment } \\
\hline Control & 4 & 0.27 & 0.803 & -0.68 & 0.537 & 1.56 & 0.193 & -2.08 & 0.106 & -4.36 & 0.012 \\
\hline Cut & 9 & -5.58 & $<0.001$ & -2.05 & 0.071 & -3.16 & 0.012 & -3.88 & 0.004 & -3.28 & 0.010 \\
\hline Foliar & 9 & 1.58 & 0.150 & 0.81 & 0.439 & 1.88 & 0.093 & 2.10 & 0.065 & 1.99 & 0.078 \\
\hline Mechanical & 9 & -4.06 & 0.003 & -3.81 & 0.004 & -3.93 & 0.003 & -4.82 & $<0.001$ & -3.10 & 0.013 \\
\hline Stump & 9 & -3.04 & 0.014 & 0.08 & 0.939 & -4.72 & 0.001 & -0.54 & 0.602 & -0.66 & 0.527 \\
\hline
\end{tabular}


Appendix XIa. Continued.

\begin{tabular}{|c|c|c|c|c|c|c|c|c|c|c|c|}
\hline \multirow[b]{2}{*}{ Variable } & \multirow[b]{2}{*}{$d f$} & \multicolumn{2}{|c|}{ Exotic richness } & \multicolumn{2}{|c|}{ Diversity (H') } & \multicolumn{2}{|c|}{ Evenness (J') } & \multicolumn{2}{|c|}{ Mean $C$} & \multicolumn{2}{|c|}{$F Q I$} \\
\hline & & $t$ & $\mathrm{p}$ & $t$ & $\mathrm{p}$ & $t$ & $p$ & $t$ & $\mathrm{p}$ & $t$ & $p$ \\
\hline \multicolumn{12}{|l|}{ Season } \\
\hline Spring & 22 & -5.83 & $<0.001$ & -8.87 & $<0.001$ & -5.88 & $<0.001$ & -6.94 & $<0.001$ & -7.78 & $<0.001$ \\
\hline Fall & 21 & 0.39 & 0.699 & 1.71 & 0.102 & 0.96 & 0.347 & -5.36 & $<0.001$ & -1.80 & 0.086 \\
\hline \multicolumn{12}{|l|}{ Treatment } \\
\hline$\overline{\text { Control }}$ & 4 & -0.99 & 0.378 & -5.45 & 0.006 & -4.87 & 0.008 & -6.41 & 0.003 & -11.96 & $<0.001$ \\
\hline Cut & 9 & -4.40 & 0.002 & -1.61 & 0.141 & -0.71 & 0.494 & -4.73 & 0.001 & -4.52 & 0.002 \\
\hline Foliar & 9 & 2.14 & 0.061 & 0.58 & 0.575 & -0.54 & 0.605 & -4.20 & 0.002 & 0.10 & 0.924 \\
\hline Mechanical & 9 & -6.32 & $<0.001$ & -5.24 & $<0.001$ & -3.31 & 0.009 & -2.24 & 0.052 & -4.13 & 0.003 \\
\hline Stump & 9 & -0.39 & 0.705 & 0.28 & 0.784 & 0.22 & 0.835 & -3.99 & 0.003 & -2.62 & 0.028 \\
\hline
\end{tabular}


Appendix XIIa. Post-treatment mean $( \pm \mathrm{SE})$ herbaceous measurements for $455 \times 5$-m plots under different seasons and treatments were recorded at Fort Necessity National Battlefield, Pennsylvania, U.S.A. in July 2005.

\begin{tabular}{|c|c|c|c|c|c|c|c|c|c|c|c|}
\hline & & $\begin{array}{c}\text { Total } \\
\text { cover }(\%)\end{array}$ & $\begin{array}{c}\text { Native } \\
\text { cover }(\%)\end{array}$ & $\begin{array}{c}\text { Exotic } \\
\text { cover }(\%)\end{array}$ & $\begin{array}{c}\text { Total } \\
\text { richness }\end{array}$ & $\begin{array}{l}\text { Native } \\
\text { richness }\end{array}$ & $\begin{array}{c}\text { Exotic } \\
\text { richness }\end{array}$ & $\begin{array}{c}\text { Diversity } \\
\left(H^{\prime}\right)\end{array}$ & $\begin{array}{c}\text { Evenness } \\
\left(J^{\prime}\right)\end{array}$ & Mean $C$ & $F Q I$ \\
\hline Season-Treatment ${ }^{*}$ & $n$ & $\bar{X} \pm S E$ & $\bar{X} \pm S E$ & $\bar{X} \pm S E$ & $\bar{X} \pm S E$ & $\bar{X} \pm S E$ & $\bar{X} \pm S E$ & $\bar{X} \pm S E$ & $\bar{X} \pm S E$ & $\bar{X} \pm S E$ & $\bar{X} \pm S E$ \\
\hline Spring-Control & 3 & $\begin{array}{l}35.7 \pm 4.3 \\
\mathrm{EF}\end{array}$ & $\begin{array}{l}21.9 \pm 3.1 \\
\mathrm{BC}\end{array}$ & $\begin{array}{l}13.8 \pm 1.3 \\
\mathrm{D}\end{array}$ & $\begin{array}{l}18.3 \pm 1.2 \\
\text { BCD }\end{array}$ & $\begin{array}{l}9.9 \pm 0.5 \\
B\end{array}$ & $\begin{array}{l}8.4 \pm 0.7 \\
\text { ABC }\end{array}$ & $\begin{array}{l}2.45 \pm 0.04 \\
\mathrm{BCD}\end{array}$ & $\begin{array}{l}0.85 \pm 0.03 \\
A B\end{array}$ & $\begin{array}{l}3.83 \pm 0.15 \\
\mathrm{~A}\end{array}$ & $\begin{array}{l}11.8 \pm 0.6 \\
\text { B }\end{array}$ \\
\hline Autumn-Control & 2 & $\begin{array}{l}24.2 \pm 0.4 \\
\mathrm{GF}\end{array}$ & $\begin{array}{l}12.2 \pm 0.4 \\
C\end{array}$ & $\begin{array}{l}12.0 \pm 0.1 \\
\mathrm{D}\end{array}$ & $\begin{array}{l}16.0 \pm 0.2 \\
\mathrm{BCD}\end{array}$ & $\begin{array}{l}8.5 \pm 0.5 \\
\mathrm{BC}\end{array}$ & $\begin{array}{l}7.5 \pm 0.3 \\
\mathrm{BC}\end{array}$ & $\begin{array}{l}2.36 \pm 0.08 \\
C D\end{array}$ & $\begin{array}{l}0.86 \pm 0.03 \\
\text { A }\end{array}$ & $\begin{array}{l}3.90 \pm 0.01 \\
\text { A }\end{array}$ & $\begin{array}{l}11.3 \pm 0.4 \\
\text { B }\end{array}$ \\
\hline Spring-Cut & 5 & $\begin{array}{l}68.8 \pm 3.8 \\
\mathrm{~A}\end{array}$ & $\begin{array}{l}42.3 \pm 3.5 \\
\mathrm{~A}\end{array}$ & $\begin{array}{l}26.4 \pm 2.6 \\
\mathrm{BC}\end{array}$ & $\begin{array}{l}23.3 \pm 1.6 \\
\mathrm{~A}\end{array}$ & $\begin{array}{l}13.6 \pm 1.2 \\
\mathrm{~A}\end{array}$ & $\begin{array}{l}9.7 \pm 0.6 \\
\mathrm{AB}\end{array}$ & $\begin{array}{l}2.69 \pm 0.07 \\
\mathrm{AB}\end{array}$ & $\begin{array}{l}0.86 \pm 0.02 \\
\mathrm{~A}\end{array}$ & $\begin{array}{l}3.98 \pm 0.07 \\
\mathrm{~A}\end{array}$ & $\begin{array}{l}14.5 \pm 0.5 \\
\mathrm{~A}\end{array}$ \\
\hline Autumn-Cut & 5 & $\begin{array}{l}64.3 \pm 4.0 \\
\mathrm{AB}\end{array}$ & $\begin{array}{l}20.3 \pm 3.2 \\
\mathrm{C}\end{array}$ & $\begin{array}{l}44.0 \pm 5.6 \\
\mathrm{~A}\end{array}$ & $\begin{array}{l}19.3 \pm 1.2 \\
\mathrm{BC}\end{array}$ & $\begin{array}{l}9.7 \pm 0.8 \\
\text { B }\end{array}$ & $\begin{array}{l}9.6 \pm 0.9 \\
\mathrm{AB}\end{array}$ & $\begin{array}{l}2.12 \pm 0.21 \\
\mathrm{DE}\end{array}$ & $\begin{array}{l}0.71 \pm 0.06 \\
C D\end{array}$ & $\begin{array}{l}3.80 \pm 0.06 \\
\text { A }\end{array}$ & $\begin{array}{l}11.6 \pm 0.5 \\
\text { B }\end{array}$ \\
\hline Spring-Foliar & 5 & $\begin{array}{l}38.4 \pm 3.0 \\
\mathrm{DE}\end{array}$ & $\begin{array}{l}20.6 \pm 3.2 \\
C\end{array}$ & $\begin{array}{l}17.8 \pm 1.4 \\
\mathrm{CD}\end{array}$ & $\begin{array}{l}15.2 \pm 1.0 \\
\mathrm{D}\end{array}$ & $\begin{array}{l}8.4 \pm 0.6 \\
\mathrm{BC}\end{array}$ & $\begin{array}{l}6.8 \pm 0.5 \\
\mathrm{C}\end{array}$ & $\begin{array}{l}2.24 \pm 0.09 \\
\mathrm{CDE}\end{array}$ & $\begin{array}{l}0.83 \pm 0.02 \\
\mathrm{AB}\end{array}$ & $\begin{array}{l}3.78 \pm 0.09 \\
\mathrm{~A}\end{array}$ & $\begin{array}{l}10.8 \pm 0.2 \\
\mathrm{BC}\end{array}$ \\
\hline Autumn-Foliar & 5 & $\begin{array}{l}19.3 \pm 2.6 \\
G\end{array}$ & $\begin{array}{l}12.8 \pm 2.9 \\
\mathrm{C}\end{array}$ & $\begin{array}{l}6.5 \pm 1.2 \\
\mathrm{E}\end{array}$ & $\begin{array}{l}11.5 \pm 1.0 \\
\mathrm{E}\end{array}$ & $\begin{array}{l}6.7 \pm 0.6 \\
C\end{array}$ & $\begin{array}{l}4.8 \pm 0.6 \\
D\end{array}$ & $\begin{array}{l}1.87 \pm 0.14 \\
\mathrm{EF}\end{array}$ & $\begin{array}{l}0.77 \pm 0.04 \\
\mathrm{BC}\end{array}$ & $\begin{array}{l}3.86 \pm 0.04 \\
\mathrm{~A}\end{array}$ & $\begin{array}{l}9.8 \pm 0.3 \\
C\end{array}$ \\
\hline Spring-Mechanical & 5 & $\begin{array}{l}61.4 \pm 5.1 \\
\mathrm{AB}\end{array}$ & $\begin{array}{l}38.9 \pm 3.9 \\
\mathrm{~A}\end{array}$ & $\begin{array}{l}22.5 \pm 3.2 \\
\mathrm{C}\end{array}$ & $\begin{array}{l}23.5 \pm 1.5 \\
\mathrm{~A}\end{array}$ & $\begin{array}{l}13.9 \pm 0.9 \\
\text { A }\end{array}$ & $\begin{array}{l}9.6 \pm 0.8 \\
\mathrm{AB}\end{array}$ & $\begin{array}{l}2.77 \pm 0.06 \\
\mathrm{~A}\end{array}$ & $\begin{array}{l}0.88 \pm 0.01 \\
\mathrm{~A}\end{array}$ & $\begin{array}{l}3.72 \pm 0.05 \\
\mathrm{~A}\end{array}$ & $\begin{array}{l}13.8 \pm 0.4 \\
\text { A }\end{array}$ \\
\hline Autumn-Mechanical & 5 & $\begin{array}{l}46.9 \pm 2.1 \\
\mathrm{CDE}\end{array}$ & $\begin{array}{l}21.0 \pm 2.2 \\
C\end{array}$ & $\begin{array}{l}25.9 \pm 1.4 \\
\mathrm{BC}\end{array}$ & $\begin{array}{l}20.0 \pm 0.5 \\
\mathrm{AB}\end{array}$ & $\begin{array}{l}9.4 \pm 0.5 \\
\text { B }\end{array}$ & $\begin{array}{l}10.6 \pm 0.5 \\
\mathrm{~A}\end{array}$ & $\begin{array}{l}2.52 \pm 0.05 \\
\mathrm{ABC}\end{array}$ & $\begin{array}{l}0.85 \pm 0.01 \\
\mathrm{AB}\end{array}$ & $\begin{array}{l}3.77 \pm 0.16 \\
\mathrm{~A}\end{array}$ & $\begin{array}{l}11.5 \pm 0.4 \\
\text { B }\end{array}$ \\
\hline Spring-Stump & 5 & $\begin{array}{l}57.3 \pm 7.5 \\
\mathrm{ABC}\end{array}$ & $\begin{array}{l}34.1 \pm 6.1 \\
\mathrm{AB}\end{array}$ & $\begin{array}{l}23.3 \pm 1.9 \\
\mathrm{C}\end{array}$ & $\begin{array}{l}18.3 \pm 1.0 \\
\text { BCD }\end{array}$ & $\begin{array}{l}10.1 \pm 0.6 \\
\text { B }\end{array}$ & $\begin{array}{l}8.2 \pm 0.5 \\
\mathrm{BC}\end{array}$ & $\begin{array}{l}2.40 \pm 0.03 \\
\mathrm{BCD}\end{array}$ & $\begin{array}{l}0.83 \pm 0.02 \\
\mathrm{AB}\end{array}$ & $\begin{array}{l}3.74 \pm 0.05 \\
\mathrm{~A}\end{array}$ & $\begin{array}{l}11.8 \pm 0.3 \\
\text { B }\end{array}$ \\
\hline Autumn-Stump & 5 & $\begin{array}{l}50.6 \pm 3.0 \\
\mathrm{BCD}\end{array}$ & $\begin{array}{l}14.4 \pm 2.6 \\
C\end{array}$ & $\begin{array}{l}36.2 \pm 4.8 \\
\mathrm{AB}\end{array}$ & $\begin{array}{l}15.4 \pm 1.2 \\
\mathrm{CD}\end{array}$ & $\begin{array}{l}8.2 \pm 0.6 \\
\mathrm{BC}\end{array}$ & $\begin{array}{l}7.1 \pm 0.6 \\
\mathrm{C}\end{array}$ & $\begin{array}{l}1.74 \pm 0.16 \\
F\end{array}$ & $\begin{array}{l}0.63 \pm 0.05 \\
\mathrm{D}\end{array}$ & $\begin{array}{l}3.94 \pm 0.06 \\
\mathrm{~A}\end{array}$ & $\begin{array}{l}11.2 \pm 0.5 \\
\mathrm{BC}\end{array}$ \\
\hline
\end{tabular}

* Means in columns with different letters are significantly different $(p<0.05)$, based on Duncan's multiple range tests. 
Appendix XIIIa. We calculated mean percent cover and percent frequency of 93 herbaceous species during our pre-treatment surveys in May 2004 and August 2004 within $455 \times 5$-m plots (225 $1 \times 1$-m nested subplots) at Fort Necessity National Battlefield, Pennsylvania, U.S.A.

Bold-faced species are exotic.

\begin{tabular}{|c|c|c|}
\hline Species & $\%$ cover & $\%$ frequency \\
\hline Anthoxanthum odoratum & $8.46 \%$ & $89.8 \%$ \\
\hline Solidago rugosa & $3.51 \%$ & $84.9 \%$ \\
\hline Solidago juncea & $2.64 \%$ & $66.7 \%$ \\
\hline Rubus flagellaris & $1.96 \%$ & $49.3 \%$ \\
\hline Dactylis glomerata & $1.88 \%$ & $56.0 \%$ \\
\hline Symphyotrichum lateriflorum & $1.86 \%$ & $78.2 \%$ \\
\hline Lycopodium digitatum & $1.44 \%$ & $14.7 \%$ \\
\hline Clinopodium vulgare & $1.31 \%$ & $74.2 \%$ \\
\hline Achillea millefolium & $1.07 \%$ & $48.9 \%$ \\
\hline Potentilla simplex & $0.96 \%$ & $62.2 \%$ \\
\hline Holcus lanatus & $0.91 \%$ & $49.8 \%$ \\
\hline Leucanthemum vulgare & $0.78 \%$ & $82.7 \%$ \\
\hline Veronica officinalis & $0.77 \%$ & $52.9 \%$ \\
\hline Hieracium caespitosum & $0.76 \%$ & $66.2 \%$ \\
\hline Prunella vulgaris & $0.64 \%$ & $46.2 \%$ \\
\hline Lonicera morrowii & $0.59 \%$ & $92.0 \%$ \\
\hline Agrostis gigantea & $0.51 \%$ & $8.9 \%$ \\
\hline Danthonia spicata & $0.48 \%$ & $10.7 \%$ \\
\hline Acer rubrum & $0.44 \%$ & $48.0 \%$ \\
\hline Poa trivialis & $0.40 \%$ & $8.4 \%$ \\
\hline
\end{tabular}


Appendix XIIIa. Continued.

\begin{tabular}{|c|c|c|}
\hline Species & $\%$ cover & $\%$ frequency \\
\hline Plantago lanceolata & $0.38 \%$ & $38.2 \%$ \\
\hline Andropogon virginicus & $0.32 \%$ & $6.2 \%$ \\
\hline Trifolium repens & $0.31 \%$ & $39.1 \%$ \\
\hline Botrychium dissectum & $0.31 \%$ & $47.1 \%$ \\
\hline Ranunculus acris & $0.31 \%$ & $29.3 \%$ \\
\hline Oxalis stricta & $0.27 \%$ & $39.6 \%$ \\
\hline Fragaria virginiana & $0.21 \%$ & $26.7 \%$ \\
\hline Rudbeckia hirta & $0.19 \%$ & $11.6 \%$ \\
\hline Crataegus pruinosa & $0.19 \%$ & $16.9 \%$ \\
\hline Dichanthelium spp. & $0.18 \%$ & $22.7 \%$ \\
\hline Solidago canadensis & $0.16 \%$ & $8.4 \%$ \\
\hline Symphyotrichum puniceum & $0.16 \%$ & $11.1 \%$ \\
\hline Euthamia graminifolia & $0.15 \%$ & $3.6 \%$ \\
\hline Prunus serotina & $0.14 \%$ & $20.4 \%$ \\
\hline Danthonia compressa & $0.14 \%$ & $0.9 \%$ \\
\hline Cerastium fontanum & $0.12 \%$ & $20.9 \%$ \\
\hline Rubus hispidus & $0.11 \%$ & $0.4 \%$ \\
\hline Vernonia gigantea ssp. gigantea & $0.10 \%$ & $4.4 \%$ \\
\hline Daucus carota & $0.10 \%$ & $13.8 \%$ \\
\hline Viburnum recognitum & $0.10 \%$ & $12.4 \%$ \\
\hline Rumex acetosella & $0.09 \%$ & $14.2 \%$ \\
\hline Solidago caesia var. curtisii & $0.09 \%$ & $8.0 \%$ \\
\hline Symphyotrichum prenanthoides & $0.08 \%$ & $9.3 \%$ \\
\hline
\end{tabular}


Appendix XIIIa. Continued.

\begin{tabular}{|c|c|c|}
\hline Species & $\%$ cover & $\%$ frequency \\
\hline Viola sororia & $0.08 \%$ & $15.1 \%$ \\
\hline Solanum carolinense & $0.07 \%$ & $6.2 \%$ \\
\hline Erigeron strigosus var. strigosus & $0.07 \%$ & $9.3 \%$ \\
\hline Taraxacum officinale & $0.06 \%$ & $7.6 \%$ \\
\hline Malus coronaria & $0.05 \%$ & $2.2 \%$ \\
\hline Trifolium aureum & $0.05 \%$ & $4.0 \%$ \\
\hline Dianthus armeria & $0.04 \%$ & $6.7 \%$ \\
\hline Veronica serpyllifolia & $0.04 \%$ & $7.1 \%$ \\
\hline Stellaria longifolia & $0.04 \%$ & $7.6 \%$ \\
\hline Solidago nemoralis & $0.03 \%$ & $3.1 \%$ \\
\hline Phleum pratense & $0.03 \%$ & $0.9 \%$ \\
\hline Packera aurea & $0.02 \%$ & $0.9 \%$ \\
\hline Symphyotrichum pilosum & $0.02 \%$ & $3.1 \%$ \\
\hline Doellingeria umbellata & $0.02 \%$ & $2.7 \%$ \\
\hline Platanthera lacera & $0.02 \%$ & $3.6 \%$ \\
\hline Clematis virginiana & $0.02 \%$ & $0.9 \%$ \\
\hline Lobelia inflata & $0.02 \%$ & $2.2 \%$ \\
\hline Toxicodendron radicans & $0.02 \%$ & $1.3 \%$ \\
\hline Dichanthelium clandestinum & $0.01 \%$ & $1.8 \%$ \\
\hline Elymus trachycaulus & $0.01 \%$ & $0.4 \%$ \\
\hline Liriodendron tulipifera & $0.01 \%$ & $1.3 \%$ \\
\hline Muhlenbergia schreberi & $0.01 \%$ & $0.9 \%$ \\
\hline Trifolium pratense & $0.01 \%$ & $0.9 \%$ \\
\hline
\end{tabular}


Appendix XIIIa. Continued.

\begin{tabular}{|c|c|c|}
\hline Species & $\%$ cover & $\%$ frequency \\
\hline Rhus copallinum & $0.01 \%$ & $0.9 \%$ \\
\hline Vitis aestivalis & $0.01 \%$ & $1.3 \%$ \\
\hline Carex blanda & $0.01 \%$ & $0.9 \%$ \\
\hline Hypericum punctatum & $0.01 \%$ & $1.8 \%$ \\
\hline Rosa multiflora & $0.01 \%$ & $1.3 \%$ \\
\hline Fraxinus americana & $<0.01 \%$ & $0.4 \%$ \\
\hline Oenothera perennis & $<0.01 \%$ & $0.9 \%$ \\
\hline Ophioglossum vulgatum & $<0.01 \%$ & $0.4 \%$ \\
\hline Quercus alba & $<0.01 \%$ & $0.9 \%$ \\
\hline Smilax rotundifolia & $<0.01 \%$ & $0.9 \%$ \\
\hline Viola sagittata & $<0.01 \%$ & $0.9 \%$ \\
\hline Allium vineale & $<0.01 \%$ & $0.4 \%$ \\
\hline Ambrosia artemisiifolia & $<0.01 \%$ & $0.4 \%$ \\
\hline Amelanchier arborea & $<0.01 \%$ & $0.4 \%$ \\
\hline Apocynum cannabinum & $<0.01 \%$ & $0.4 \%$ \\
\hline Asplenium platyneuron & $<0.01 \%$ & $0.4 \%$ \\
\hline Berberis thunbergii & $<0.01 \%$ & $0.4 \%$ \\
\hline Botrychium virginianum & $<0.01 \%$ & $0.4 \%$ \\
\hline Juncus tenuis & $<0.01 \%$ & $0.4 \%$ \\
\hline Lactuca canadensis & $<0.01 \%$ & $0.4 \%$ \\
\hline Lysimachia lanceolata & $<0.01 \%$ & $0.4 \%$ \\
\hline Mitchella repens & $<0.01 \%$ & $0.4 \%$ \\
\hline Plantago rugelii & $<0.01 \%$ & $0.4 \%$ \\
\hline
\end{tabular}


Appendix XIIIa. Continued.

\begin{tabular}{lcc}
\hline Species & \% cover & $\%$ frequency \\
\hline Quercus rubra & $<0.01 \%$ & $0.4 \%$ \\
Robinia pseudoacacia & $<0.01 \%$ & $0.4 \%$ \\
Sisyrinchium angustifolium & $<0.01 \%$ & $0.4 \%$ \\
Viola blanda & $<0.01 \%$ & $0.4 \%$ \\
\hline
\end{tabular}


Appendix XIVa. List of shrubs and herbs, their exotic/native status, and coefficient of conservatism values (COC) (J. Rentch, West Virginia University, Division of Forestry, unpublished data) from $455 \times 5-\mathrm{m}$ shrub plots and $2251 \times 1-\mathrm{m}$ nested herb plots placed in a degraded meadow dominated by Morrow's honeysuckle at Fort Necessity National Battlefield, Pennsylvania, U.S.A. during the summer of 2004 and 2005. Bold-faced species are exotic.

\begin{tabular}{|c|c|c|c|}
\hline Family & Species & Common Name & $C O C$ \\
\hline Aceraceae & Acer rubrum L. & Red Maple & 3 \\
\hline Aceraceae & Acer saccharum Marsh. var. saccharum & Sugar Maple & 5 \\
\hline Anacardiaceae & Rhus copallinum $\mathrm{L}$. & Winged Sumac & 6 \\
\hline Anacardiaceae & Toxicodendron radicans (L.) Kuntze & Eastern Poison Ivy & 3 \\
\hline Apiaceae & Daucus carota $\mathrm{L}$. & Queen Anne's Lace & $\mathbf{0}$ \\
\hline Apocynaceae & Apocynum cannabinum $\mathrm{L}$. & Indian Hemp & 3 \\
\hline Asclepiadaceae & Asclepias tuberosa $\mathrm{L}$. & Butterfly Milkweed & 3 \\
\hline Aspleniaceae & Asplenium platyneuron (L.) B.S.P. & Ebony Spleenwort & 5 \\
\hline Asteraceae & Achillea millefolium L. var. occidentalis DC. & Common Yarrow & $\mathbf{0}$ \\
\hline Asteraceae & Ambrosia artemisiifolia L. var. elatior (L.) Descourtils & Annual Ragweed & 1 \\
\hline Asteraceae & Cirsium arvense (L.) Scop. & Canada Thistle & $\mathbf{0}$ \\
\hline Asteraceae & Doellingeria umbellata (P. Mill.) Nees var. umbellata & Parasol Whitetop & 5 \\
\hline Asteraceae & Erigeron strigosus Muhl. ex Willd. var. strigosus & Prairie Fleabane & 2 \\
\hline Asteraceae & Eurybia divaricata (L.) Nesom & White Wood Aster & 4 \\
\hline Asteraceae & Euthamia graminifolia (L.) Nutt. var. graminifolia & Flat-top Goldentop & 4 \\
\hline Asteraceae & Hieracium caespitosum Dumort. & Meadow Hawkweed & $\mathbf{0}$ \\
\hline Asteraceae & Hypochaeris radicata $\mathrm{L}$. & Hairy Catsear & $\mathbf{0}$ \\
\hline Asteraceae & Lactuca canadensis $\mathrm{L}$. & Canada Lettuce & 3 \\
\hline Asteraceae & Leucanthemum vulgare Lam. & Oxeye Daisy & $\mathbf{0}$ \\
\hline Asteraceae & Packera aurea (L.) A.\& D. Löve & Golden Ragwort & 4 \\
\hline Asteraceae & Rudbeckia hirta L. & Blackeyed Susan & 4 \\
\hline
\end{tabular}


Appendix XIVa. Continued.

\begin{tabular}{|c|c|c|c|}
\hline Family & Species & Common Name & $C O C$ \\
\hline Asteraceae & Solidago caesia L. & $\begin{array}{l}\text { Mountain Decumbent } \\
\text { Goldenrod }\end{array}$ & 6 \\
\hline Asteraceae & Solidago canadensis L. & Canada Goldenrod & 3 \\
\hline Asteraceae & Solidago juncea Ait. & Early Goldenrod & 5 \\
\hline Asteraceae & Solidago nemoralis Ait. var. nemoralis & Gray Goldenrod & 5 \\
\hline Asteraceae & Solidago rugosa P. Mill. & Wrinkleleaf Goldenrod & 3 \\
\hline Asteraceae & Symphyotrichum lateriflorum (L.) A.\& D. Löve & Calico Aster & 4 \\
\hline Asteraceae & Symphyotrichum pilosum (Willd.) Nesom & $\begin{array}{l}\text { Hairy White Oldfield } \\
\text { Aster }\end{array}$ & 4 \\
\hline Asteraceae & Symphyotrichum prenanthoides (Muhl. ex Willd.) Nesom & Crookedstem Aster & 5 \\
\hline Asteraceae & Symphyotrichum puniceum (L.) A.\& D. Löve var. puniceum & Purplestem Aster & 6 \\
\hline Asteraceae & $\begin{array}{l}\text { Taraxacum officinale G.H. Weber ex Wiggers ssp. } \\
\text { officinale }\end{array}$ & Common Dandelion & 0 \\
\hline Asteraceae & Vernonia gigantea (Walt.) Trel. ssp. gigantea & Giant Ironweed & 3 \\
\hline Berberidaceae & Berberis thunbergii DC. & Japanese Barberry & $\mathbf{0}$ \\
\hline Campanulaceae & Lobelia inflata $\mathrm{L}$. & Indian-tobacco & 3 \\
\hline Caprifoliaceae & Lonicera morrowii Gray & $\begin{array}{l}\text { Morrow's } \\
\text { Honeysuckle }\end{array}$ & 0 \\
\hline Caprifoliaceae & Viburnum lentago L. & Nannyberry & 7 \\
\hline Caprifoliaceae & Viburnum recognitum Fern. & Southern Arrowwood & 6 \\
\hline Caryophyllaceae & $\begin{array}{l}\text { Cerastium fontanum Baumg. ssp. vulgare (Hartman) } \\
\text { Greuter \& Burdet }\end{array}$ & $\begin{array}{l}\text { Common Mouse-ear } \\
\text { Chickweed }\end{array}$ & 0 \\
\hline Caryophyllaceae & Dianthus armeria L. & Deptford Pink & $\mathbf{0}$ \\
\hline Caryophyllaceae & Stellaria longifolia Muhl. ex Willd. var. longifolia & Longleaf Starwort & 6 \\
\hline Clusiaceae & Hypericum punctatum Lam. & Spotted St. John's Wort & 4 \\
\hline Convolvulaceae & Calystegia sepium (L.) R. Br. ssp. sepium & $\begin{array}{l}\text { Hedge False } \\
\text { Bindweed }\end{array}$ & 0 \\
\hline Cornaceae & Cornus racemosa Lam. & Gray Dogwood & 6 \\
\hline Cyperaceae & Carex blanda Dewey & $\begin{array}{l}\text { Eastern Woodland } \\
\text { Sedge }\end{array}$ & 7 \\
\hline Cyperaceae & Carex debilis Michx. ssp. rudgei (Bailey) A.\& D. Löve & White Edge Sedge & 6 \\
\hline Cyperaceae & Carex hirsutella Mackenzie & Fuzzy Wuzzy Sedge & 4 \\
\hline Cyperaceae & Carex spp. & A sedge & 0 \\
\hline
\end{tabular}


Appendix XIVa. Continued.

\begin{tabular}{|c|c|c|c|}
\hline Family & Species & Common Name & $C O C$ \\
\hline Elaeagnaceae & $\begin{array}{l}\text { Elaeagnus umbellata Thunb. var. parvifolia (Royle) } \\
\text { Schneid. }\end{array}$ & Autumn Olive & $\mathbf{0}$ \\
\hline Ericaceae & Vaccinium stamineum $\mathrm{L}$. & Deerberry & 4 \\
\hline Fabaceae & Robinia pseudoacacia $\mathrm{L}$. & Black Locust & 2 \\
\hline Fabaceae & Trifolium aureum Pollich & Golden Clover & $\mathbf{0}$ \\
\hline Fabaceae & Trifolium pratense $\mathrm{L}$. & Red Clover & $\mathbf{0}$ \\
\hline Fabaceae & Trifolium repens $\mathbf{L}$. & White Clover & $\mathbf{0}$ \\
\hline Fagaceae & Quercus alba $\mathrm{L}$. & White Oak & 5 \\
\hline Fagaceae & Quercus rubra $\mathrm{L}$. & Northern Red Oak & 5 \\
\hline Iridaceae & Sisyrinchium angustifolium P. Mill. & $\begin{array}{l}\text { Narrowleaf Blue-eyed } \\
\text { Grass }\end{array}$ & 4 \\
\hline Juncaceae & Juncus tenuis Willd. & Poverty Rush & 3 \\
\hline Lamiaceae & Clinopodium vulgare $\mathrm{L}$. & Wild Basil & 2 \\
\hline Lamiaceae & Lycopus virginicus $\mathrm{L}$. & $\begin{array}{l}\text { Virginia Water } \\
\text { Horehound }\end{array}$ & 4 \\
\hline Lamiaceae & Prunella vulgaris L. & Common Selfheal & 1 \\
\hline Lauraceae & Sassafras albidum (Nutt.) Nees & Sassafras & 4 \\
\hline Lilliaceae & Allium vineale L. ssp. Vineale & Wild Garlic & $\mathbf{0}$ \\
\hline Lycopodiaceae & Lycopodium clavatum $\mathrm{L}$. & Running Clubmoss & 5 \\
\hline Lycopodiaceae & Lycopodium digitatum Dill. ex A. Braun & Fan Clubmoss & 4 \\
\hline Magnoliaceae & Liriodendron tulipifera $\mathrm{L}$. & Tulip Poplar & 5 \\
\hline Nyssaceae & Nyssa sylvatica Marsh. & Black Gum & 4 \\
\hline Oleaceae & Fraxinus americana $\mathrm{L}$. & White Ash & 6 \\
\hline Onagraceae & Oenothera perennis $\mathrm{L}$. & Little Evening Primrose & 5 \\
\hline Ophioglossaceae & Botrychium dissectum Spreng. & Cutleaf Grapefern & 4 \\
\hline Ophioglossaceae & Botrychium virginianum (L.) Sw. & Rattlesnake Fern & 5 \\
\hline Ophioglossaceae & Ophioglossum vulgatum $\mathrm{L}$. & Adderstongue & 7 \\
\hline Orchidaceae & Platanthera lacera (Michx.) G. Don & Green Fringed Orchid & 6 \\
\hline Oxalidaceae & Oxalis stricta $\mathrm{L}$. & $\begin{array}{l}\text { Common Yellow } \\
\text { Oxalis }\end{array}$ & 2 \\
\hline
\end{tabular}


Appendix XIVa. Continued.

\begin{tabular}{|c|c|c|c|}
\hline Family & Species & Common Name & $\overline{C O C}$ \\
\hline Plantaginaceae & Plantago lanceolata $\mathrm{L}$. & Narrowleaf Plantain & $\mathbf{0}$ \\
\hline Plantaginaceae & Plantago rugelii Dcne. var. rugelii & Blackseed Plantain & 2 \\
\hline Poaceae & Agrostis gigantea Roth & Redtop & $\mathbf{0}$ \\
\hline Poaceae & Andropogon virginicus $\mathrm{L}$. var. virginicus & Broomsedge Bluestem & 3 \\
\hline Poaceae & Anthoxanthum odoratum L. ssp. odoratum & Sweet Vernal Grass & $\mathbf{0}$ \\
\hline Poaceae & Arrhenatherum elatius (L.) Beauv. Ex J.\& K. Presl & Tall Oatgrass & $\mathbf{0}$ \\
\hline Poaceae & Bromus inermis Leyss. ssp. inermis var. inermis & Smooth Brome & $\mathbf{0}$ \\
\hline Poaceae & Dactylis glomerata L. ssp. glomerata & Orchard Grass & $\mathbf{0}$ \\
\hline Poaceae & Danthonia compressa Austin ex Peck & Flattened Oatgrass & 6 \\
\hline Poaceae & Danthonia spicata (L.) Beauv. ex Roemer \& J.A. Schultes & Poverty Oatgrass & 5 \\
\hline Poaceae & Dichanthelium clandestinum (L.) Gould & Deertongue & 3 \\
\hline Poaceae & Dichanthelium meridionale (Ashe) Freckman & Matting Rosette Grass & 6 \\
\hline Poaceae & Dichanthelium sphaerocarpon (Ell.) Gould & Roundseed Panicgrass & 4 \\
\hline Poaceae & Dichanthelium spp. & Panic Grass & 0 \\
\hline Poaceae & Elymus repens (L.) Gould & Quackgrass & $\mathbf{0}$ \\
\hline Poaceae & $\begin{array}{l}\text { Elymus trachycaulus (Link) Gould ex Shinners ssp. } \\
\text { trachycaulus }\end{array}$ & Slender Wheatgrass & 8 \\
\hline Poaceae & Glyceria striata (Lam.) A.S. Hitchc. & Fowl Mannagrass & 5 \\
\hline Poaceae & Holcus lanatus L. & Common Velvet Grass & $\mathbf{0}$ \\
\hline Poaceae & Muhlenbergia schreberi J.F. Gmel. & Nimblewill & 5 \\
\hline Poaceae & Muhlenbergia spp. & Muhly & 0 \\
\hline Poaceae & Phleum pratense $\mathrm{L}$. & Timothy & $\mathbf{0}$ \\
\hline Poaceae & Poa palustris $\mathrm{L}$. & Fowl Bluegrass & 6 \\
\hline Poaceae & Poa trivialis $\mathbf{L}$. & Rough Bluegrass & $\mathbf{0}$ \\
\hline Poaceae & Tridens flavus (L.) A.S. Hitchc. var. flavus & Purpletop Tridens & 3 \\
\hline Polygalaceae & Polygala verticillata $\mathrm{L}$. & Whorled Milkwort & 6 \\
\hline Polygonaceae & Polygonum persicaria L. & Spotted Ladysthumb & $\mathbf{0}$ \\
\hline
\end{tabular}


Appendix XIVa. Continued.

\begin{tabular}{|c|c|c|c|}
\hline Family & Species & Common Name & $C O C$ \\
\hline Polygonaceae & Rumex acetosella $\mathrm{L}$. & Sheep Sorrel & $\mathbf{0}$ \\
\hline Primulaceae & Lysimachia lanceolata Walt. & Lanceleaf Loosestrife & 6 \\
\hline Ranunculaceae & Clematis virginiana $\mathrm{L}$. & Virgin's Bower & 4 \\
\hline Ranunculaceae & Ranunculus acris L. var. acris & Tall Buttercup & $\mathbf{0}$ \\
\hline Rosaceae & Agrimonia gryposepala Wallr. & Tall Hairy Agrimony & 4 \\
\hline Rosaceae & Amelanchier arborea (Michx. f.) Fern. var. arborea & Common Serviceberry & 5 \\
\hline Rosaceae & Crataegus pruinosa (Wendl. f.) K. Koch & Waxyfruit Hawthorne & 5 \\
\hline Rosaceae & Fragaria virginiana Duchesne ssp. virginiana & Virginia Strawberry & 3 \\
\hline Rosaceae & Malus coronaria (L.) P. Mill. var. coronaria & Sweet Crabapple & 3 \\
\hline Rosaceae & Potentilla simplex Michx. & Common Cinquefoil & 4 \\
\hline Rosaceae & Prunus mahaleb L. & Mahaleb Cherry & $\mathbf{0}$ \\
\hline Rosaceae & Prunus serotina Ehrh. var. serotina & Black Cherry & 4 \\
\hline Rosaceae & Rosa multiflora Thunb. ex Murr. & Multiflora Rose & $\mathbf{0}$ \\
\hline Rosaceae & Rubus flagellaris Willd. & Northern Dewberry & 5 \\
\hline Rosaceae & Rubus hispidus L. & Bristly Dewberry & 5 \\
\hline Rubiaceae & Mitchella repens $\mathrm{L}$. & Partridgeberry & 5 \\
\hline Scrophulariaceae & Veronica officinalis $\mathbf{L}$. & Common Gypsyweed & $\mathbf{0}$ \\
\hline Scrophulariaceae & Veronica serpyllifolia L. ssp. serpyllifolia & Thymeleaf Speedwell & $\mathbf{0}$ \\
\hline Simaroubaceae & Ailanthus altissima (P. Mill.) Swingle & Tree of Heaven & $\mathbf{0}$ \\
\hline Smilaceae & Smilax glauca Walt. & Cat Greenbrier & 5 \\
\hline Smilaceae & Smilax rotundifolia $\mathrm{L}$. & Roundleaf Greenbrier & 4 \\
\hline Solanaceae & Physalis heterophylla Nees var. heterophylla & Clammy Groundcherry & 3 \\
\hline Solanaceae & Solanum carolinense L. var. carolinense & Carolina Horsenettle & 3 \\
\hline Violaceae & Viola blanda Willd. & Sweet White Violet & 5 \\
\hline Violaceae & Viola sagittata Ait. & Arrowleaf Violet & 6 \\
\hline Violaceae & Viola sororia Willd. & Common Blue Violet & 4 \\
\hline
\end{tabular}


Appendix XIVa. Continued.

\begin{tabular}{lllc}
\hline Family & Species & Common Name & COC \\
\hline Vitaceae & Vitis aestivalis Michx. & Summer Grape & 5 \\
\hline
\end{tabular}


Appendix Ib. Linear regression models explaining influence of biotic and abiotic environmental variables on patterns of invertebrate abundance under different shrub types $(n=167)$ in a degraded meadow at Fort Necessity National Battlefield, Pennsylvania, U.S.A. Model rankings were based on Akaike's Information Criterion corrected for small sample size $\left(\mathrm{AIC}_{\mathrm{c}}\right)$.

\begin{tabular}{lcccc}
\hline Model $^{\mathrm{a}}$ & $K^{\mathrm{b}}$ & $A I C_{c}$ & $\Delta A I C_{c}^{\mathrm{c}}$ & $w_{i}^{\mathrm{d}}$ \\
\hline Global $(S H, H C, N C, L M, L N, S M, S T, D M)$ & 13 & 506.13 & 0.00 & 1.00 \\
Soil (SM, ST) & 4 & 524.60 & 18.47 & 0.00 \\
Debris (DM) & 3 & 533.65 & 27.52 & 0.00 \\
Shrub (SH) & 6 & 539.49 & 33.36 & 0.00 \\
Total herbs (HC) & 3 & 547.47 & 41.34 & 0.00 \\
Native herbs $(N C)$ & 3 & 553.54 & 49.64 & 0.00 \\
Litter $(L M, L N)$ & 4 & 554.32 & 50.32 & 0.00 \\
\hline
\end{tabular}

${ }^{a}$ Abbreviations in parentheses correspond to model parameters in Table 1 of Chapter 3.

${ }^{\mathrm{b}}$ Number of estimable parameters in approximating model.

${ }^{\mathrm{c}}$ Difference in value between $\mathrm{AIC}_{\mathrm{c}}$ of the current model versus the best-approximating model $\left(\mathrm{AIC}_{\mathrm{cmin}}\right)$.

${ }^{d}$ Akaike weight. Probability that the current model (i) is the best-approximating model among those considered. 
Appendix IIb. Linear regression models explaining influence of biotic and abiotic environmental variables on patterns of invertebrate biomass under different shrub types $(n=167)$ in a degraded meadow at Fort Necessity National Battlefield, Pennsylvania, U.S.A. Model rankings were based on Akaike's Information Criterion corrected for small sample size ( $\left.\mathrm{AIC}_{\mathrm{c}}\right)$.

\begin{tabular}{lcccc}
\hline Model $^{\mathrm{a}}$ & $K^{\mathrm{b}}$ & \multicolumn{1}{c}{$A I C_{c}$} & $\Delta A I C_{c}^{\mathrm{c}}$ & $w_{i}^{\mathrm{d}}$ \\
\hline Shrub (SH) & 6 & 427.16 & 0.00 & 0.98 \\
Debris (DM) & 3 & 435.45 & 8.29 & 0.02 \\
Total herbs (HC) & 3 & 438.77 & 11.61 & 0.00 \\
Native herbs (NC) & 3 & 439.83 & 12.67 & 0.00 \\
Litter (LM, LN) & 4 & 441.06 & 13.90 & 0.00 \\
Global (SH, HC, NC, LM, LN, SM, ST, DM) & 13 & 441.31 & 14.15 & 0.00 \\
Soil (SM, ST) & 4 & 442.48 & 15.31 & 0.00 \\
\hline
\end{tabular}

${ }^{a}$ Abbreviations in parentheses correspond to model parameters in Table 1 of Chapter 3.

${ }^{\mathrm{b}}$ Number of estimable parameters in approximating model.

${ }^{\mathrm{c}}$ Difference in value between $\mathrm{AIC}_{\mathrm{c}}$ of the current model versus the best-approximating model $\left(\mathrm{AIC}_{\mathrm{cmin}}\right)$.

${ }^{d}$ Akaike weight. Probability that the current model (i) is the best-approximating model among those considered. 
Appendix IIIb. Abundance, frequency, and total biomass (mg) of 87 invertebrate groups sampled on 45 lone Morrow's honeysuckle shrubs at Fort Necessity National Battlefield, Pennsylvania, U.S.A. during July 2004 and May and August 2005.

\begin{tabular}{|c|c|c|c|c|c|c|c|}
\hline Class & Order & Taxonomic group & Common name & Stage & Abundance & Frequency & Total biomass $(\mathrm{mg})$ \\
\hline Insecta & Homoptera & Cicadellidae & Leafhoppers & Adult & 267 & 40 & 130.4 \\
\hline Insecta & Coleoptera & Staphylinidae & Rove Beetles & Adult & 72 & 6 & 53.2 \\
\hline Insecta & Hymenoptera & Formicidae & Ants & Adult & 58 & 19 & 20.3 \\
\hline Insecta & Homoptera & Psyllidae & Jumping Plantlice & Adult & 58 & 16 & 22.3 \\
\hline Insecta & Diptera & Chironomidae & Midges & Adult & 40 & 8 & 10.0 \\
\hline Insecta & Hemiptera & Miridae & Plant Bugs & Adult & 34 & 12 & 31.5 \\
\hline Arachnida & Araneae & Salticidae & Jumping Spiders & Adult & 31 & 22 & 42.0 \\
\hline Arachnida & Araneae & Araneidae & Orb Weavers & Adult & 29 & 21 & 66.6 \\
\hline Insecta & Hemiptera & Pentatomidae & Stink Bugs & Adult & 27 & 16 & 122.2 \\
\hline Arachnida & Opiliones & Phalangiidae & Harvestmen & Adult & 23 & 15 & 180.3 \\
\hline Insecta & Hymenoptera & Braconidae & Braconids & Adult & 23 & 12 & 4.9 \\
\hline Insecta & Diptera & Drosophilidae & Small Fruit Flies & Adult & 23 & 10 & 6.1 \\
\hline Insecta & Diptera & Muscidae & House Flies and Allies & Adult & 21 & 13 & 20.1 \\
\hline Insecta & Diptera & Lauxaniidae & Lauxaniid Flies & Adult & 21 & 11 & 16.6 \\
\hline Arachnida & Araneae & Thomasidae & Crab Spiders & Adult & 19 & 11 & 31.6 \\
\hline Insecta & Diptera & Sciaridae & Dark-winged Fungus Gnats & Adult & 19 & 10 & 3.8 \\
\hline Insecta & Lepidoptera & Gracillariidae & Leafblotch Miners & Adult & 16 & 13 & 3.2 \\
\hline Insecta & Hymenoptera & Scelionidae & Scelionid Wasps & Adult & 16 & 10 & 2.4 \\
\hline Insecta & Orthoptera & Gryllidae & Crickets & Adult & 14 & 10 & 110.6 \\
\hline
\end{tabular}


Appendix IIIb. Continued.

\begin{tabular}{|c|c|c|c|c|c|c|c|}
\hline Class & Order & Taxonomic group & Common name & Stage & Abundance & Frequency & Total biomass $(\mathrm{mg})$ \\
\hline Gastropoda & Stylommatophora & Stylommatophora & Land Snails and Slugs & Adult & 13 & 10 & 99.1 \\
\hline Insecta & Diptera & Dolichopodidae & Long-legged Flies & Adult & 13 & 8 & 3.6 \\
\hline Insecta & Coleoptera & Chrysomelidae & Leaf Beetles & Adult & 12 & 10 & 39.4 \\
\hline Insecta & Diptera & Heleomyzidae & Heleomyzid Flies & Adult & 12 & 9 & 3.0 \\
\hline Insecta & Hemiptera & Nabidae & Damsel Bugs & Adult & 12 & 8 & 16.5 \\
\hline Insecta & Coleoptera & Cantharidae & Soldier Beetles & Adult & 12 & 5 & 15.9 \\
\hline Insecta & Lepidoptera & Pyralidae & Snout Moths & Adult & 10 & 8 & 27.7 \\
\hline Insecta & Homoptera & Cercopidae & Spittlebugs & Adult & 10 & 7 & 34.2 \\
\hline Insecta & Diptera & Empididae & Dance Flies & Adult & 10 & 5 & 8.0 \\
\hline Insecta & Coleoptera & Phalacridae & Shining Fungus Beetles & Adult & 9 & 8 & 2.5 \\
\hline Insecta & Diptera & Otitidae & Picture Flies & Adult & 9 & 5 & 8.7 \\
\hline Insecta & Orthoptera & Acrididae & Short-horned Grasshoppers & Adult & 8 & 7 & 94.9 \\
\hline Insecta & Coleoptera & Coccinellidae & Ladybugs & Adult & 7 & 6 & 84.2 \\
\hline Insecta & Diptera & Tipulidae & Crane Flies & Adult & 7 & 3 & 9.0 \\
\hline Insecta & Coleoptera & Oedemeridae & False Blister Beetles & Adult & 6 & 4 & 19.6 \\
\hline Insecta & Homoptera & Aphididae & Aphids & Adult & 5 & 4 & 1.0 \\
\hline Insecta & Lepidoptera & Arctiidae & Tiger Moths & Larva & 5 & 4 & 83.5 \\
\hline Insecta & Diptera & Chloropidae & Grass Flies & Adult & 5 & 4 & 1.1 \\
\hline Insecta & Coleoptera & Mycetophagidae & Hairy Fungus Beetles & Adult & 5 & 1 & 1.8 \\
\hline Insecta & Neuroptera & Chrysopidae & Common Lacewings & Adult & 4 & 4 & 12.5 \\
\hline
\end{tabular}


Appendix IIIb. Continued.

\begin{tabular}{|c|c|c|c|c|c|c|c|}
\hline Class & Order & Taxonomic group & Common name & Stage & Abundance & Frequency & Total biomass $(\mathrm{mg})$ \\
\hline Insecta & Hemiptera & Coreidae & Leaf-footed Bugs & Adult & 4 & 4 & 31.4 \\
\hline Insecta & Coleoptera & Curculionidae & Snout Beetles & Adult & 4 & 3 & 4.3 \\
\hline Insecta & Hymenoptera & Symphyta & Sawflies and Horntails & Larva & 4 & 3 & 7.4 \\
\hline Insecta & Diptera & Tephritidae & Fruit Flies & Adult & 4 & 3 & 9.0 \\
\hline Insecta & Coleoptera & Elateridae & Click Beetles & Adult & 3 & 3 & 24.2 \\
\hline Insecta & Lepidoptera & Noctuidae & Noctuids & Adult & 3 & 3 & 5.1 \\
\hline Insecta & Hemiptera & Reduviidae & Assasin Bugs & Adult & 3 & 3 & 9.7 \\
\hline Insecta & Hymenoptera & Apidae & Bumble Bees \& Honey Bees & Adult & 3 & 2 & 136.1 \\
\hline Insecta & Diptera & Agromyzidae & Leaf-miner Flies & Adult & 2 & 2 & 0.5 \\
\hline Insecta & Diptera & Anthomyzidae & Anthomyzid Flies & Adult & 2 & 2 & 0.7 \\
\hline Insecta & Homoptera & Cixiidae & Planthoppers & Adult & 2 & 2 & 2.3 \\
\hline Insecta & Homoptera & Delphacidae & Planthoppers & Adult & 2 & 2 & 0.8 \\
\hline Insecta & Diptera & Diptera & Flies & Adult & 2 & 2 & 1.3 \\
\hline Insecta & Neuroptera & Hemerobiidae & Brown Lacewings & Adult & 2 & 2 & 2.1 \\
\hline Insecta & Hemiptera & Largidae & Largid Bugs & Adult & 2 & 2 & 1.5 \\
\hline Insecta & Lepidoptera & Lepidoptera & Moth & Larva & 2 & 2 & 0.3 \\
\hline Insecta & Hemiptera & Lygaeidae & Seed Bugs & Adult & 2 & 2 & 4.3 \\
\hline Insecta & Homoptera & Membracidae & Treehoppers & Adult & 2 & 2 & 5.5 \\
\hline Insecta & Lepidoptera & Noctuidae & Noctuids & Larva & 2 & 2 & 13.6 \\
\hline Insecta & Mecoptera & Panorpidae & Common Scorpionflies & Adult & 2 & 2 & 7.2 \\
\hline
\end{tabular}


Appendix IIIb. Continued.

\begin{tabular}{|c|c|c|c|c|c|c|c|}
\hline Class & Order & Taxonomic group & Common name & Stage & Abundance & Frequency & Total biomass $(\mathrm{mg})$ \\
\hline Insecta & Lepidoptera & Pyralidae & Snout Moths & Larva & 2 & 2 & 2.8 \\
\hline Insecta & Diptera & Rhagionidae & Snipe Flies & Adult & 2 & 2 & 3.9 \\
\hline Insecta & Diptera & Sepsidae & Black Scavenger Flies & Adult & 2 & 2 & 0.8 \\
\hline Insecta & Diptera & Simuliidae & Black Flies & Adult & 2 & 2 & 0.7 \\
\hline Insecta & Hymenoptera & Tenthredinidae & Sawflies & Adult & 2 & 2 & 2.1 \\
\hline Insecta & Orthoptera & Tettigoniidae & Katydids & Adult & 2 & 2 & 24.6 \\
\hline Insecta & Dermaptera & Forficulidae & Spine-tailed Earwigs & Adult & 2 & 1 & 78.6 \\
\hline Insecta & Orthoptera & Gryllacrididae & Wingless Long-horned Grasshoppers & Adult & 2 & 1 & 10.4 \\
\hline Insecta & Hemiptera & Rhopalidae & Scentless Plant Bugs & Adult & 2 & 1 & 3.4 \\
\hline Insecta & Lepidoptera & Arctiidae & Tiger Moths & Adult & 1 & 1 & 22.7 \\
\hline Insecta & Coleoptera & Bruchidae & Seed Beetles & Adult & 1 & 1 & 0.5 \\
\hline Insecta & Diptera & Cecidomyiidae & Gall Midges & Adult & 1 & 1 & 0.3 \\
\hline Insecta & Coleoptera & Cerambycidae & Long-horned Beetles & Adult & 1 & 1 & 1.8 \\
\hline Insecta & Neuroptera & Chrysopidae & Common Lacewings & Larva & 1 & 1 & 0.1 \\
\hline Insecta & Coleoptera & Cicindelidae & Tiger Beetles & Adult & 1 & 1 & 3.7 \\
\hline Insecta & Diptera & Culicidae & Mosquitoes & Adult & 1 & 1 & 0.3 \\
\hline Insecta & Homoptera & Flatidae & Planthoppers & Adult & 1 & 1 & 1.9 \\
\hline Insecta & Lepidoptera & Gelechiidae & Gelechiid Moths & Adult & 1 & 1 & 1.3 \\
\hline Insecta & Hymenoptera & Ichneumonidae & Ichneumons & Adult & 1 & 1 & 0.6 \\
\hline Insecta & Homoptera & Issidae & Planthoppers & Adult & 1 & 1 & 0.6 \\
\hline
\end{tabular}


Appendix IIIb. Continued.

\begin{tabular}{|c|c|c|c|c|c|c|c|}
\hline Class & Order & Taxonomic group & Common name & Stage & Abundance & Frequency & Total biomass ( $\mathrm{mg}$ ) \\
\hline Insecta & Lepidoptera & Lasiocampidae & Tent Caterpillars & Larva & 1 & 1 & 0.3 \\
\hline Arachnida & Araneae & Linyphiidae & Sheet-web Spiders & Adult & 1 & 1 & 0.5 \\
\hline Insecta & Lepidoptera & Lyonetiidae & A Moth & Adult & 1 & 1 & 0.2 \\
\hline Insecta & Coleoptera & Melandryidae & False Darkling Beetles & Adult & 1 & 1 & 0.5 \\
\hline Insecta & Diptera & Milichiidae & Milichiid Flies & Adult & 1 & 1 & 0.2 \\
\hline Insecta & Diptera & Phoridae & Humpbacked Flies & Adult & 1 & 1 & 0.2 \\
\hline Insecta & Psocoptera & Polypsocidae & Bark Lice & Adult & 1 & 1 & 0.2 \\
\hline Insecta & Diptera & Sciomyzidae & Marsh Flies & Adult & 1 & 1 & 0.4 \\
\hline Insecta & Coleoptera & Scolytidae & Bark Beetles & Adult & 1 & 1 & 0.3 \\
\hline Insecta & Lepidoptera & Sesiidae & Clearwing Moths & Adult & 1 & 1 & 0.3 \\
\hline Arachnida & Araneae & Theridiidae & Comb-footed Spiders & Adult & 1 & 1 & 0.4 \\
\hline Insecta & Lepidoptera & Tortricidae & Leafrolling Moths & Adult & 1 & 1 & 5.2 \\
\hline
\end{tabular}


Appendix IVb. Abundance, frequency, and total biomass (mg) of 89 invertebrate groups sampled on 45 lone southern arrowwood shrubs at Fort Necessity National Battlefield, Pennsylvania, U.S.A. during July 2004 and May and August 2005.

\begin{tabular}{|c|c|c|c|c|c|c|c|}
\hline Class & Order & Taxonomic group & Common name & Stage & Abundance & Frequency & Total biomass ( $\mathrm{mg}$ ) \\
\hline Insecta & Hymenoptera & Formicidae & Ants & Adult & 292 & 32 & 121.8 \\
\hline Insecta & Homoptera & Cicadellidae & Leafhoppers & Adult & 106 & 32 & 87.3 \\
\hline Insecta & Hymenoptera & Scelionidae & Scelionid Wasps & Adult & 67 & 26 & 9.9 \\
\hline Insecta & Diptera & Chironomidae & Midges & Adult & 67 & 7 & 17.8 \\
\hline Insecta & Homoptera & Aphididae & Aphids & Adult & 62 & 5 & 13.0 \\
\hline Insecta & Hemiptera & Miridae & Plant Bugs & Adult & 44 & 19 & 29.5 \\
\hline Insecta & Hymenoptera & Braconidae & Braconids & Adult & 42 & 20 & 13.4 \\
\hline Insecta & Coleoptera & Curculionidae & Snout Beetles & Adult & 39 & 17 & 9.5 \\
\hline Insecta & Hemiptera & Pentatomidae & Stink Bugs & Adult & 33 & 10 & 124.9 \\
\hline Insecta & Hymenoptera & Symphyta & Sawflies and Horntails & Larva & 28 & 14 & 98.9 \\
\hline Arachnida & Araneae & Salticidae & Jumping Spiders & Adult & 25 & 20 & 45.9 \\
\hline Insecta & Diptera & Dolichopodidae & Long-legged Flies & Adult & 20 & 9 & 4.6 \\
\hline Insecta & Coleoptera & Coccinellidae & Ladybugs & Adult & 17 & 13 & 266.0 \\
\hline Insecta & Coleoptera & Chrysomelidae & Leaf Beetles & Adult & 16 & 13 & 46.5 \\
\hline Insecta & Diptera & Empididae & Dance Flies & Adult & 16 & 11 & 5.1 \\
\hline Arachnida & Araneae & Araneidae & Orb Weavers & Adult & 15 & 13 & 15.7 \\
\hline Insecta & Diptera & Sciaridae & Dark-winged Fungus Gnats & Adult & 15 & 12 & 2.6 \\
\hline Insecta & Coleoptera & Staphylinidae & Rove Beetles & Adult & 15 & 8 & 6.2 \\
\hline Insecta & Diptera & Lauxaniidae & Lauxaniid Flies & Adult & 13 & 10 & 8.9 \\
\hline
\end{tabular}


Appendix IVb. Continued.

\begin{tabular}{|c|c|c|c|c|c|c|c|}
\hline Class & Order & Taxonomic group & Common name & Stage & Abundance & Frequency & Total biomass ( $\mathrm{mg}$ ) \\
\hline Insecta & Homoptera & Psyllidae & Jumping Plantlice & Adult & 13 & 7 & 5.1 \\
\hline Insecta & Diptera & Chloropidae & Grass Flies & Adult & 12 & 7 & 3.9 \\
\hline Insecta & Diptera & Muscidae & House Flies and Allies & Adult & 11 & 10 & 5.8 \\
\hline Insecta & Lepidoptera & Geometridae & Measuringworms & Larva & 11 & 7 & 18.8 \\
\hline Insecta & Coleoptera & Pedilidae & Pedilid Beetles & Adult & 9 & 5 & 3.8 \\
\hline Arachnida & Araneae & Thomasidae & Crab Spiders & Adult & 8 & 7 & 10.7 \\
\hline Insecta & Homoptera & Issidae & Planthoppers & Adult & 8 & 4 & 3.2 \\
\hline Insecta & Diptera & Drosophilidae & Small Fruit Flies & Adult & 7 & 6 & 1.7 \\
\hline Insecta & Coleoptera & Cleridae & Checkered Beetles & Adult & 7 & 5 & 8.9 \\
\hline Insecta & Hymenoptera & Ichneumonidae & Ichneumons & Adult & 6 & 5 & 4.1 \\
\hline Insecta & Collembola & Isotomidae & Springtails & Adult & 6 & 1 & 0.2 \\
\hline Insecta & Coleoptera & Byrrhidae & Pill Beetles & Adult & 5 & 4 & 5.0 \\
\hline Insecta & Coleoptera & Cantharidae & Soldier Beetles & Adult & 5 & 4 & 6.4 \\
\hline Insecta & Lepidoptera & Gracillariidae & Leafblotch Miners & Adult & 5 & 4 & 0.5 \\
\hline Insecta & Homoptera & Derbidae & Planthoppers & Adult & 5 & 2 & 1.6 \\
\hline Insecta & Orthoptera & Gryllidae & Crickets & Adult & 4 & 4 & 49.5 \\
\hline Insecta & Lepidoptera & Pyralidae & Snout Moths & Larva & 4 & 4 & 0.8 \\
\hline Insecta & Diptera & Tipulidae & Crane Flies & Adult & 4 & 4 & 19.0 \\
\hline Insecta & Diptera & Sciomyzidae & Marsh Flies & Adult & 4 & 2 & 2.2 \\
\hline Insecta & Lepidoptera & Arctiidae & Tiger Moths & Larva & 4 & 1 & 4.2 \\
\hline
\end{tabular}


Appendix IVb. Continued.

\begin{tabular}{|c|c|c|c|c|c|c|c|}
\hline Class & Order & Taxonomic group & Common name & Stage & Abundance & Frequency & Total biomass ( $\mathrm{mg})$ \\
\hline Insecta & Diptera & Diptera & Flies & Puparia & 4 & 1 & $\mathrm{~N} / \mathrm{A}$ \\
\hline Insecta & Diptera & Bibionidae & March Flies & Adult & 3 & 3 & 4.3 \\
\hline Insecta & Homoptera & Cercopidae & Spittlebugs & Adult & 3 & 3 & 11.6 \\
\hline Insecta & Lepidoptera & Lyonetiidae & A Moth & Adult & 3 & 3 & 0.3 \\
\hline Insecta & Lepidoptera & Noctuidae & Noctuids & Larva & 3 & 3 & 4.2 \\
\hline Arachnida & Opiliones & Phalangiidae & Harvestmen & Adult & 3 & 3 & 16.1 \\
\hline Insecta & Psocoptera & Polypsocidae & Bark Lice & Adult & 3 & 3 & 0.4 \\
\hline Insecta & Lepidoptera & Pyralidae & Snout Moths & Adult & 3 & 3 & 3.9 \\
\hline Insecta & Coleoptera & Carabidae & Ground Beetles & Adult & 3 & 2 & 1.5 \\
\hline Insecta & Homoptera & Flatidae & Planthoppers & Adult & 3 & 2 & 8.6 \\
\hline Insecta & Coleoptera & Phalacridae & Shining Fungus Beetles & Adult & 3 & 2 & 0.8 \\
\hline Arachnida & Araneae & Dictynidae & Hackled-band Weavers & Adult & 2 & 2 & 0.8 \\
\hline Insecta & Coleoptera & Oedemeridae & False Blister Beetles & Adult & 2 & 2 & 5.5 \\
\hline Arachnida & Araneae & Philodromidae & Crab Spiders & Adult & 2 & 2 & 1.8 \\
\hline Insecta & Diptera & Pipunculidae & Big-headed Flies & Adult & 2 & 2 & 1.2 \\
\hline Insecta & Diptera & Tabanidae & Horse Flies \& Deer Flies & Adult & 2 & 2 & 6.3 \\
\hline Insecta & Hymenoptera & Tenthredinidae & Sawflies & Adult & 2 & 2 & 6.5 \\
\hline Arachnida & Araneae & Theridiidae & Comb-footed Spiders & Adult & 2 & 2 & 1.6 \\
\hline Insecta & Lepidoptera & Tortricidae & Leafrolling Moths & Larva & 2 & 2 & 21.8 \\
\hline Insecta & Diptera & Diptera & Flies & Larva & 2 & 1 & 3.0 \\
\hline
\end{tabular}


Appendix IVb. Continued.

\begin{tabular}{|c|c|c|c|c|c|c|c|}
\hline Class & Order & Taxonomic group & Common name & Stage & Abundance & Frequency & Total biomass (mg) \\
\hline Insecta & Coleoptera & Erotylidae & Pleasing Fungus Beetles & Adult & 2 & 1 & 0.4 \\
\hline Insecta & Diptera & Heleomyzidae & Heleomyzid Flies & Adult & 2 & 1 & 0.5 \\
\hline Insecta & Hemiptera & Nabidae & Damsel Bugs & Adult & 2 & 1 & 0.4 \\
\hline Insecta & Collembola & Sminthuridae & Springtails & Adult & 2 & 1 & 0.1 \\
\hline Insecta & Diptera & Agromyzidae & Leaf-miner Flies & Adult & 1 & 1 & 0.4 \\
\hline Insecta & Coleoptera & Bruchidae & Seed Beetles & Adult & 1 & 1 & 2.5 \\
\hline Insecta & Neuroptera & Chrysopidae & Common Lacewings & Adult & 1 & 1 & 2.9 \\
\hline Insecta & Homoptera & Cixiidae & Planthoppers & Adult & 1 & 1 & 1.5 \\
\hline Arachnida & Araneae & Clubionidae & Two-clawed Hunting Spiders & Adult & 1 & 1 & 0.6 \\
\hline Insecta & Coleoptera & Coccinellidae & Ladybugs & Larva & 1 & 1 & 0.6 \\
\hline Insecta & Homoptera & Delphacidae & Planthoppers & Adult & 1 & 1 & 0.7 \\
\hline Insecta & Coleoptera & Elateridae & Click Beetles & Adult & 1 & 1 & 7.5 \\
\hline Insecta & Dermaptera & Forficulidae & Spine-tailed Earwigs & Adult & 1 & 1 & 9.4 \\
\hline Insecta & Lepidoptera & Geometridae & Measuringworms & Adult & 1 & 1 & 5.7 \\
\hline Insecta & Hymenoptera & Halictidae & Sweat Bees & Adult & 1 & 1 & 4.7 \\
\hline Insecta & Coleoptera & Lampyridae & Lightningbugs & Adult & 1 & 1 & 0.9 \\
\hline Arachnida & Araneae & Linyphiidae & Sheet-web Spiders & Adult & 1 & 1 & 1.2 \\
\hline Insecta & Neuroptera & Mantispidae & Mantidflies & Larva & 1 & 1 & 0.4 \\
\hline Insecta & Coleoptera & Melyridae & Soft-winged Flower Beetles & Adult & 1 & 1 & 1.3 \\
\hline Insecta & Homoptera & Membracidae & Treehoppers & Adult & 1 & 1 & 0.7 \\
\hline
\end{tabular}


Appendix IVb. Continued.

\begin{tabular}{|c|c|c|c|c|c|c|c|}
\hline Class & Order & Taxonomic group & Common name & Stage & Abundance & Frequency & Total biomass ( $\mathrm{mg}$ ) \\
\hline Insecta & Diptera & Milichiidae & Milichiid Flies & Adult & 1 & 1 & 0.8 \\
\hline Insecta & Coleoptera & Mordellidae & Tumbling Flower Beetles & Adult & 1 & 1 & 0.3 \\
\hline Insecta & Diptera & Mycetophilidae & Fungus Gnats & Adult & 1 & 1 & 0.5 \\
\hline Insecta & Lepidoptera & Notodontidae & Prominents & Larva & 1 & 1 & 4.5 \\
\hline Insecta & Diptera & Phoridae & Humpbacked Flies & Adult & 1 & 1 & 0.2 \\
\hline Insecta & Hymenoptera & Platygastridae & Platygastrids & Adult & 1 & 1 & 0.2 \\
\hline Insecta & Lepidoptera & Plutellidae & Diamondback Moths & Larva & 1 & 1 & 0.6 \\
\hline Insecta & Psocoptera & Psocidae & Bark Lice & Adult & 1 & 1 & 0.1 \\
\hline Insecta & Diptera & Rhagionidae & Snipe Flies & Adult & 1 & 1 & 2.4 \\
\hline Insecta & Coleoptera & Scarabaeidae & Scarab Beetles & Adult & 1 & 1 & 31.2 \\
\hline Insecta & Diptera & Sepsidae & Black Scavenger Flies & Adult & 1 & 1 & 0.6 \\
\hline Insecta & Orthoptera & Tettigoniidae & Katydids & Adult & 1 & 1 & 8.0 \\
\hline Insecta & Thysanoptera & Thripidae & Common Thrips & Adult & 1 & 1 & 0.1 \\
\hline
\end{tabular}


Appendix Vb. Abundance, frequency, and total biomass (mg) of 85 invertebrate groups sampled on 45 dense thickets of Morrow's honeysuckle at Fort Necessity National Battlefield, Pennsylvania, U.S.A. during July 2004 and May and August 2005.

\begin{tabular}{|c|c|c|c|c|c|c|c|}
\hline Class & Order & Taxonomic group & Common name & Stage & Abundance & Frequency & Total biomass $(\mathrm{mg})$ \\
\hline Insecta & Homoptera & Cicadellidae & Leafhoppers & Adult & 139 & 40 & 78.0 \\
\hline Insecta & Diptera & Drosophilidae & Small Fruit Flies & Adult & 59 & 21 & 16.4 \\
\hline Insecta & Hemiptera & Miridae & Plant Bugs & Adult & 47 & 22 & 33.1 \\
\hline Insecta & Hemiptera & Reduviidae & Assasin Bugs & Adult & 41 & 20 & 75.6 \\
\hline Insecta & Coleoptera & Staphylinidae & Rove Beetles & Adult & 34 & 9 & 29.3 \\
\hline Insecta & Diptera & Sciaridae & Dark-winged Fungus Gnats & Adult & 29 & 12 & 5.0 \\
\hline Arachnida & Opiliones & Phalangiidae & Harvestmen & Adult & 27 & 22 & 171.3 \\
\hline Insecta & Diptera & Lauxaniidae & Lauxaniid Flies & Adult & 27 & 10 & 18.7 \\
\hline Insecta & Hymenoptera & Braconidae & Braconids & Adult & 26 & 16 & 8.5 \\
\hline Insecta & Diptera & Muscidae & House Flies and Allies & Adult & 24 & 16 & 25.5 \\
\hline Insecta & Hemiptera & Pentatomidae & Stink Bugs & Adult & 23 & 14 & 130.4 \\
\hline Arachnida & Araneae & Araneidae & Orb Weavers & Adult & 22 & 16 & 30.3 \\
\hline Insecta & Diptera & Dolichopodidae & Long-legged Flies & Adult & 22 & 14 & 8.5 \\
\hline Insecta & Diptera & Chloropidae & Grass Flies & Adult & 22 & 13 & 5.9 \\
\hline Insecta & Hymenoptera & Formicidae & Ants & Adult & 21 & 8 & 19.1 \\
\hline Insecta & Coleoptera & Chrysomelidae & Leaf Beetles & Adult & 19 & 10 & 131.2 \\
\hline Insecta & Lepidoptera & Gracillariidae & Leafblotch Miners & Adult & 18 & 13 & 4.5 \\
\hline Insecta & Diptera & Empididae & Dance Flies & Adult & 17 & 11 & 6.7 \\
\hline Arachnida & Araneae & Salticidae & Jumping Spiders & Adult & 15 & 12 & 23.0 \\
\hline
\end{tabular}


Appendix Vb. Continued.

\begin{tabular}{|c|c|c|c|c|c|c|c|}
\hline Class & Order & Taxonomic group & Common name & Stage & Abundance & Frequency & Total biomass ( $\mathrm{mg}$ \\
\hline Insecta & Homoptera & Psyllidae & Jumping Plantlice & Adult & 15 & 9 & 5.2 \\
\hline Insecta & Collembola & Sminthuridae & Springtails & Adult & 15 & 5 & 0.6 \\
\hline Insecta & Orthoptera & Acrididae & Short-horned Grasshoppers & Adult & 14 & 8 & 129.0 \\
\hline Insecta & Diptera & Tephritidae & Fruit Flies & Adult & 14 & 8 & 10.2 \\
\hline Insecta & Diptera & Chironomidae & Midges & Adult & 14 & 7 & 3.3 \\
\hline Insecta & Diptera & Tipulidae & Crane Flies & Adult & 12 & 9 & 26.9 \\
\hline Insecta & Hymenoptera & Scelionidae & Scelionid Wasps & Adult & 11 & 10 & 2.1 \\
\hline Gastropoda & Stylommatophora & Stylommatophora & Land Snails and Slugs & Adult & 10 & 8 & 66.9 \\
\hline Insecta & Lepidoptera & Noctuidae & Noctuids & Larva & 8 & 8 & 21.5 \\
\hline Insecta & Diptera & Agromyzidae & Leaf-miner Flies & Adult & 8 & 4 & 2.0 \\
\hline Insecta & Homoptera & Cercopidae & Spittlebugs & Adult & 7 & 6 & 22.4 \\
\hline Insecta & Hemiptera & Coreidae & Leaf-footed Bugs & Adult & 7 & 6 & 96.9 \\
\hline Insecta & Orthoptera & Gryllidae & Crickets & Adult & 7 & 6 & 80.1 \\
\hline Insecta & Mecoptera & Panorpidae & Common Scorpionflies & Adult & 7 & 6 & 49.8 \\
\hline Insecta & Coleoptera & Coccinellidae & Ladybugs & Adult & 5 & 5 & 88.4 \\
\hline Insecta & Homoptera & Aphididae & Aphids & Adult & 5 & 4 & 1.1 \\
\hline Arachnida & Araneae & Thomasidae & Crab Spiders & Adult & 5 & 3 & 6.9 \\
\hline Insecta & Coleoptera & Elateridae & Click Beetles & Adult & 4 & 4 & 53.9 \\
\hline Insecta & Diptera & Otitidae & Picture Flies & Adult & 4 & 4 & 2.3 \\
\hline Insecta & Coleoptera & Coccinellidae & Ladybugs & Larva & 4 & 2 & 0.1 \\
\hline
\end{tabular}


Appendix Vb. Continued.

\begin{tabular}{|c|c|c|c|c|c|c|c|}
\hline Class & Order & Taxonomic group & Common name & Stage & Abundance & Frequency & Total biomass ( $\mathrm{mg}$ ) \\
\hline Insecta & Neuroptera & Hemerobiidae & Brown Lacewings & Adult & 3 & 3 & 4.1 \\
\hline Insecta & Lepidoptera & Pyralidae & Snout Moths & Adult & 3 & 3 & 4.5 \\
\hline Insecta & Diptera & Tachinidae & Tachina Flies & Adult & 3 & 3 & 6.7 \\
\hline Insecta & Diptera & Asilidae & Robber Flies & Adult & 3 & 2 & 3.6 \\
\hline Insecta & Coleoptera & Cantharidae & Soldier Beetles & Adult & 3 & 2 & 4.1 \\
\hline Insecta & Neuroptera & Chrysopidae & Common Lacewings & Larva & 3 & 2 & 2.1 \\
\hline Insecta & Dermaptera & Forficulidae & Spine-tailed Earwigs & Adult & 3 & 2 & 43.4 \\
\hline Insecta & Lepidoptera & Geometridae & Measuringworms & Larva & 3 & 2 & 9.4 \\
\hline Insecta & Hymenoptera & Ichneumonidae & Ichneumons & Adult & 3 & 2 & 1.8 \\
\hline Insecta & Lepidoptera & Tortricidae & Leafrolling Moths & Adult & 3 & 2 & 0.6 \\
\hline Insecta & Coleoptera & Pselaphidae & Short-winged Mold Beetles & Adult & 3 & 1 & 0.8 \\
\hline Insecta & Hymenoptera & Apidae & Bumble Bees \& Honey Bees & Adult & 2 & 2 & 81.0 \\
\hline Arachnida & Araneae & Clubionidae & Two-clawed Hunting Spiders & Adult & 2 & 2 & 2.1 \\
\hline Insecta & Coleoptera & Erotylidae & Pleasing Fungus Beetles & Adult & 2 & 2 & 0.6 \\
\hline Insecta & Diptera & Heleomyzidae & Heleomyzid Flies & Adult & 2 & 2 & 1.0 \\
\hline Insecta & Coleoptera & Lampyridae & Lightningbugs & Adult & 2 & 2 & 3.5 \\
\hline Insecta & Homoptera & Membracidae & Treehoppers & Adult & 2 & 2 & 5.0 \\
\hline Insecta & Lepidoptera & Noctuidae & Noctuids & Adult & 2 & 2 & 7.9 \\
\hline Insecta & Coleoptera & Oedemeridae & False Blister Beetles & Adult & 2 & 2 & 7.6 \\
\hline Insecta & Diptera & Rhagionidae & Snipe Flies & Adult & 2 & 2 & 7.4 \\
\hline
\end{tabular}


Appendix Vb. Continued.

\begin{tabular}{|c|c|c|c|c|c|c|c|}
\hline Class & Order & Taxonomic group & Common name & Stage & Abundance & Frequency & Total biomass ( $\mathrm{mg}$ ) \\
\hline Insecta & Diptera & Sciomyzidae & Marsh Flies & Adult & 2 & 2 & 1.4 \\
\hline Insecta & Diptera & Tabanidae & Horse Flies \& Deer Flies & Adult & 2 & 2 & 4.4 \\
\hline Insecta & Orthoptera & Tettigoniidae & Katydids & Adult & 2 & 2 & 12.3 \\
\hline Insecta & Lepidoptera & Tineidae & Clothes Moths & Adult & 2 & 2 & 1.3 \\
\hline Insecta & Hymenoptera & Tiphiidae & Tiphiids & Adult & 2 & 2 & 0.8 \\
\hline Insecta & Homoptera & Flatidae & Planthoppers & Adult & 2 & 1 & 3.4 \\
\hline Insecta & Collembola & Isotomidae & Springtails & Adult & 2 & 1 & 0.1 \\
\hline Insecta & Lepidoptera & Lyonetiidae & A Moth & Adult & 2 & 1 & 0.7 \\
\hline Insecta & Coleoptera & Alleculidae & Combclawed Beetles & Adult & 1 & 1 & 1.6 \\
\hline Insecta & Diptera & Bibionidae & March Flies & Adult & 1 & 1 & 1.9 \\
\hline Insecta & Coleoptera & Buprestidae & Metallic Wood-boring Beetles & Adult & 1 & 1 & 2.8 \\
\hline Insecta & Diptera & Calliphoridae & Blow Flies & Adult & 1 & 1 & 9.1 \\
\hline Insecta & Coleoptera & Carabidae & Ground Beetles & Adult & 1 & 1 & 1.6 \\
\hline Insecta & Coleoptera & Carabidae & Ground Beetles & Larva & 1 & 1 & 0.1 \\
\hline Insecta & Diptera & Ceratopogonidae & Biting Midges & Adult & 1 & 1 & 0.5 \\
\hline Insecta & Coleoptera & Cleridae & Checkered Beetles & Adult & 1 & 1 & 0.6 \\
\hline Insecta & Lepidoptera & Coleophoridae & Casebearer Moths & Adult & 1 & 1 & 0.1 \\
\hline Insecta & Homoptera & Delphacidae & Planthoppers & Adult & 1 & 1 & 1.1 \\
\hline Insecta & Hymenoptera & Eurytomidae & Eurytomids, Jointworms, \& Seed Chalcids & Adult & 1 & 1 & 0.2 \\
\hline Insecta & Homoptera & Fulgoridae & Planthoppers & Adult & 1 & 1 & 1.0 \\
\hline
\end{tabular}


Appendix Vb. Continued.

\begin{tabular}{|c|c|c|c|c|c|c|c|}
\hline Class & Order & Taxonomic group & Common name & Stage & Abundance & Frequency & Total biomass ( $\mathrm{mg}$ \\
\hline Insecta & Coleoptera & Melandryidae & False Darkling Beetles & Adult & 1 & 1 & 1.1 \\
\hline Insecta & Coleoptera & Pedilidae & Pedilid Beetles & Adult & 1 & 1 & 5.1 \\
\hline Insecta & Hemiptera & Rhopalidae & Scentless Plant Bugs & Adult & 1 & 1 & 4.3 \\
\hline Insecta & Diptera & Simuliidae & Black Flies & Adult & 1 & 1 & 0.2 \\
\hline Insecta & Neuroptera & Sisyridae & Spongillaflies & Adult & 1 & 1 & 0.1 \\
\hline Insecta & Diptera & Syrphidae & Flower Flies & Adult & 1 & 1 & 0.4 \\
\hline Insecta & Hymenoptera & Tenthredinidae & Sawflies & Adult & 1 & 1 & 0.4 \\
\hline Insecta & Thysanoptera & Thripidae & Common Thrips & Adult & 1 & 1 & 0.1 \\
\hline Insecta & Hymenoptera & Vespidae & Yellow Jackets, Hornets, \& Wasps & Adult & 1 & 1 & 1.1 \\
\hline
\end{tabular}


Appendix VIb . $F$ and $p$ values of abundance, biomass, and richness of invertebrates $(\geq 2 \mathrm{~mm}$ in length) sampled in the shrub strata of three shrub types during three different months at Fort Necessity National Battlefield, Pennsylvania, U.S.A.

\begin{tabular}{|c|c|c|c|c|c|c|}
\hline \multirow[b]{3}{*}{ Dependent variables } & \multicolumn{6}{|c|}{ Independent variables } \\
\hline & \multicolumn{2}{|c|}{ Shrub type } & \multicolumn{2}{|c|}{ Month } & \multicolumn{2}{|c|}{ Shrub type $\times$ month } \\
\hline & $\mathrm{F}_{[2,126]}$ & $\mathrm{p}$ & $\mathrm{F}_{[2,126]}$ & $\mathrm{p}$ & $\mathrm{F}_{[4,126]}$ & $\mathrm{p}$ \\
\hline Abundance & 0.94 & 0.394 & 11.37 & $<0.001$ & 0.92 & 0.456 \\
\hline Biomass & 3.24 & 0.043 & 2.85 & 0.062 & 0.58 & 0.677 \\
\hline Richness & 0.71 & 0.492 & 19.68 & $<0.001$ & 0.67 & 0.611 \\
\hline
\end{tabular}


Appendix VIIb. Mean ( \pm SE) abundance, biomass, and richness of invertebrates $(\geq 2 \mathrm{~mm}$ in length) sampled in the shrub strata based on shrub type and season combinations at Fort Necessity National Battlefield, Pennsylvania, U.S.A.

\begin{tabular}{|c|c|c|c|c|}
\hline Variable & $n$ & $\frac{\text { Abundance }}{\bar{X} \pm S E^{\mathrm{ab}}}$ & $\frac{\text { Biomass (mg) }}{\bar{X} \pm S E^{\mathrm{c}}}$ & $\frac{\text { Richness }}{\bar{X}+S F^{\mathrm{d}}}$ \\
\hline \multicolumn{5}{|c|}{ Lone Morrow's honeysuckle shrubs } \\
\hline May & 15 & $24.5 \pm 5.2 \mathrm{AB}$ & $36.4 \pm 7.5 \mathrm{~A}$ & $9.7 \pm 0.9 \mathrm{BC}$ \\
\hline July & 15 & $27.7 \pm 2.7 \mathrm{~A}$ & $36.3 \pm 4.2 \mathrm{~A}$ & $13.5 \pm 1.0 \mathrm{~A}$ \\
\hline August & 15 & $19.7 \pm 2.9 \mathrm{ABC}$ & $52.6 \pm 17.0 \mathrm{~A}$ & $8.9 \pm 1.1 \mathrm{C}$ \\
\hline \multicolumn{5}{|c|}{ Lone southern arrowwood shrubs } \\
\hline May & 15 & $32.7 \pm 6.6 \mathrm{~A}$ & $28.0 \pm 8.0 \mathrm{~A}$ & $10.0 \pm 1.4 \mathrm{BC}$ \\
\hline July & 15 & $29.2 \pm 4.2 \mathrm{~A}$ & $33.4 \pm 6.6 \mathrm{~A}$ & $13.3 \pm 1.1 \mathrm{~A}$ \\
\hline August & 15 & $15.3 \pm 3.1 \mathrm{BC}$ & $23.6 \pm 4.7 \mathrm{~A}$ & $7.5 \pm 0.8 \mathrm{C}$ \\
\hline \multicolumn{5}{|c|}{ Dense thickets of Morrow's honeysuckle } \\
\hline May & 15 & $22.0 \pm 3.5 \mathrm{ABC}$ & $27.4 \pm 5.9 \mathrm{~A}$ & $11.7 \pm 0.7 \mathrm{AB}$ \\
\hline July & 15 & $23.7 \pm 2.3 \mathrm{~A}$ & $47.8 \pm 5.7 \mathrm{~A}$ & $13.0 \pm 0.8 \mathrm{~A}$ \\
\hline August & 15 & $14.1 \pm 1.7 \mathrm{C}$ & $41.2 \pm 8.9 \mathrm{~A}$ & $8.4 \pm 1.0 \mathrm{C}$ \\
\hline
\end{tabular}

${ }^{a}$ Means in columns with different letters are significantly different $(p<0.05)$, based on Duncan's multiple range tests.

${ }^{\mathrm{b}} F_{[8,126]}=3.54, p=0.001$

${ }^{\mathrm{c}} F_{[8,126]}=1.81, p=0.081$

${ }^{\mathrm{d}} F_{[8,126]}=5.44, p<0.001$ 
Appendix VIIIb. Abundance, frequency, and total biomass (mg) of 74 invertebrate groups sampled in the understory of 45 lone Morrow’s honeysuckle shrubs at Fort Necessity National Battlefield, Pennsylvania, U.S.A. during July 2004 and May \& August 2005.

\begin{tabular}{|c|c|c|c|c|c|c|c|}
\hline Class & Order & Taxonomic group & Common name & Stage & Abundance & Frequency & Total biomass $(\mathrm{mg})$ \\
\hline Insecta & Collembola & Isotomidae & Springtails & Adult & 185 & 37 & 14.0 \\
\hline Insecta & Homoptera & Cicadellidae & Leafhoppers & Adult & 130 & 35 & 49.7 \\
\hline Insecta & Hymenoptera & Formicidae & Ants & Adult & 59 & 26 & 14.5 \\
\hline Insecta & Coleoptera & Chrysomelidae & Leaf Beetles & Larva & 30 & 14 & 2.4 \\
\hline Insecta & Coleoptera & Curculionidae & Snout Beetles & Adult & 27 & 13 & 29.3 \\
\hline Arachnida & Araneae & Lycosidae & Wolf Spiders & Adult & 21 & 14 & 30.8 \\
\hline Insecta & Homoptera & Psyllidae & Jumping Plantlice & Adult & 19 & 10 & 5.9 \\
\hline Insecta & Coleoptera & Chrysomelidae & Leaf Beetles & Adult & 18 & 17 & 54.2 \\
\hline Diplopoda & N/A & Diplopoda & Millipedes & Adult & 17 & 9 & 26.1 \\
\hline Insecta & Diptera & Sciaridae & Dark-winged Fungus Gnats & Adult & 17 & 6 & 2.5 \\
\hline Gastropoda & Stylommatophora & Stylommatophora & Land Snails and Slugs & Adult & 13 & 8 & 80.6 \\
\hline Arachnida & Opiliones & Phalangiidae & Harvestmen & Adult & 12 & 11 & 73.4 \\
\hline Insecta & Coleoptera & Staphylinidae & Rove Beetles & Adult & 11 & 9 & 27.3 \\
\hline Arachnida & Araneae & Salticidae & Jumping Spiders & Adult & 10 & 10 & 4.1 \\
\hline Insecta & Hemiptera & Lygaeidae & Seed Bugs & Adult & 10 & 9 & 6.3 \\
\hline Arachnida & Araneae & Araneidae & Orb Weavers & Adult & 9 & 8 & 10.3 \\
\hline Insecta & Hemiptera & Miridae & Plant Bugs & Adult & 9 & 7 & 4.9 \\
\hline Insecta & Homoptera & Delphacidae & Planthoppers & Adult & 8 & 5 & 5.3 \\
\hline Arachnida & Araneae & Clubionidae & Two-clawed Hunting Spiders & Adult & 6 & 6 & 7.1 \\
\hline
\end{tabular}


Appendix VIIIb. Continued.

\begin{tabular}{|c|c|c|c|c|c|c|c|}
\hline Class & Order & Taxonomic group & Common name & Stage & Abundance & Frequency & Total biomass ( $\mathrm{mg})$ \\
\hline Insecta & Diptera & Dolichopodidae & Long-legged Flies & Adult & 6 & 6 & 1.9 \\
\hline Insecta & Hemiptera & Reduviidae & Assasin Bugs & Adult & 6 & 6 & 10.5 \\
\hline Insecta & Diptera & Drosophilidae & Small Fruit Flies & Adult & 5 & 4 & 1.1 \\
\hline Insecta & Hymenoptera & Scelionidae & Scelionid Wasps & Adult & 5 & 4 & 0.5 \\
\hline Insecta & Coleoptera & Carabidae & Ground Beetles & Adult & 4 & 4 & 17.8 \\
\hline Insecta & Lepidoptera & Noctuidae & Noctuids & Larva & 4 & 4 & 13.8 \\
\hline Insecta & Hemiptera & Pentatomidae & Stink Bugs & Adult & 4 & 3 & 59.3 \\
\hline Insecta & Lepidoptera & Geometridae & Measuringworms & Larva & 3 & 3 & 1.7 \\
\hline Insecta & Homoptera & Aphididae & Aphids & Adult & 3 & 2 & 0.7 \\
\hline Arachnida & Acari & Trombidioidea & Mites & Adult & 2 & 2 & 0.7 \\
\hline Chilopoda & N/A & Chilopoda & Centipedes & Adult & 2 & 2 & 1.6 \\
\hline Insecta & Coleoptera & Coccinellidae & Ladybugs & Adult & 2 & 2 & 0.4 \\
\hline Insecta & Collembola & Hypogastruridae & Springtails & Adult & 2 & 2 & 0.2 \\
\hline Insecta & Diptera & Chloropidae & Grass Flies & Adult & 2 & 2 & 0.5 \\
\hline Insecta & Diptera & Empididae & Dance Flies & Adult & 2 & 2 & 0.7 \\
\hline Insecta & Diptera & Heleomyzidae & Heleomyzid Flies & Adult & 2 & 2 & 0.4 \\
\hline Insecta & Diptera & Muscidae & House Flies and Allies & Adult & 2 & 2 & 1.8 \\
\hline Insecta & Hemiptera & Nabidae & Damsel Bugs & Adult & 2 & 2 & 5.4 \\
\hline Insecta & Homoptera & Derbidae & Planthoppers & Adult & 2 & 2 & 2.0 \\
\hline Insecta & Homoptera & Membracidae & Treehoppers & Adult & 2 & 2 & 1.0 \\
\hline
\end{tabular}


Appendix VIIIb. Continued.

\begin{tabular}{|c|c|c|c|c|c|c|c|}
\hline Class & Order & Taxonomic group & Common name & Stage & Abundance & Frequency & Total biomass ( $\mathrm{mg})$ \\
\hline Insecta & Orthoptera & Gryllidae & Crickets & Adult & 2 & 2 & 9.3 \\
\hline Insecta & Orthoptera & Tetrigidae & Pygmy Grasshoppers & Adult & 2 & 2 & 22.1 \\
\hline Insecta & Coleoptera & Buprestidae & Metallic Wood-boring Beetles & Adult & 2 & 1 & 3.6 \\
\hline Insecta & Lepidoptera & Pyralidae & Snout Moths & Larva & 2 & 1 & 1.1 \\
\hline Insecta & Mecoptera & Panorpidae & Common Scorpionflies & Adult & 2 & 1 & 6.5 \\
\hline Arachnida & Araneae & Amaurobiidae & Blue Silk Spiders & Adult & 1 & 1 & 11.3 \\
\hline Arachnida & Araneae & Theridiidae & Comb-footed Spiders & Adult & 1 & 1 & 1.8 \\
\hline Arachnida & Araneae & Thomasidae & Crab Spiders & Adult & 1 & 1 & 1.1 \\
\hline Insecta & Coleoptera & Bruchidae & Seed Beetles & Adult & 1 & 1 & 0.6 \\
\hline Insecta & Coleoptera & Erotylidae & Pleasing Fungus Beetles & Adult & 1 & 1 & 0.6 \\
\hline Insecta & Coleoptera & Lampyridae & Lightningbugs & Larva & 1 & 1 & 3.2 \\
\hline Insecta & Coleoptera & Phalacridae & Shining Fungus Beetles & Adult & 1 & 1 & 0.2 \\
\hline Insecta & Coleoptera & Scydmaenidae & Antlike Stone Beetles & Adult & 1 & 1 & 0.2 \\
\hline Insecta & Diptera & Anthomyiidae & Anthomyiid Flies & Larva & 1 & 1 & 0.2 \\
\hline Insecta & Diptera & Asilidae & Robber Flies & Adult & 1 & 1 & 0.6 \\
\hline Insecta & Diptera & Calliphoridae & Blow Flies & Adult & 1 & 1 & 4.0 \\
\hline Insecta & Diptera & Cecidomyiidae & Gall Midges & Adult & 1 & 1 & 0.2 \\
\hline Insecta & Diptera & Chironomidae & Midges & Adult & 1 & 1 & 0.2 \\
\hline Insecta & Diptera & Lauxaniidae & Lauxaniid Flies & Adult & 1 & 1 & 1.1 \\
\hline Insecta & Diptera & Milichiidae & Milichiid Flies & Adult & 1 & 1 & 0.3 \\
\hline
\end{tabular}


Appendix VIIIb. Continued.

\begin{tabular}{|c|c|c|c|c|c|c|c|}
\hline Class & Order & Taxonomic group & Common name & Stage & Abundance & Frequency & Total biomass ( $\mathrm{mg})$ \\
\hline Insecta & Diptera & Tephritidae & Fruit Flies & Adult & 1 & 1 & 0.5 \\
\hline Insecta & Diptera & Tipulidae & Crane Flies & Adult & 1 & 1 & 1.9 \\
\hline Insecta & Homoptera & Coccoidea & Scale Insects & Adult & 1 & 1 & 0.4 \\
\hline Insecta & Hymenoptera & Braconidae & Braconids & Adult & 1 & 1 & 0.1 \\
\hline Insecta & Hymenoptera & Eurytomidae & Eurytomids, Jointworms, \& Seed Chalcids & Adult & 1 & 1 & 0.1 \\
\hline Insecta & Hymenoptera & Evaniidae & Ensign Wasps & Adult & 1 & 1 & 0.4 \\
\hline Insecta & Hymenoptera & Symphyta & Sawflies and Horntails & Larva & 1 & 1 & 1.8 \\
\hline Insecta & Lepidoptera & Gracillariidae & Leafblotch Miners & Adult & 1 & 1 & 0.2 \\
\hline Insecta & Lepidoptera & Psychidae & Bagworm Moths & Larva & 1 & 1 & 0.2 \\
\hline Insecta & Lepidoptera & Saturnidae & Silkworm Moths \& Royal Moths & Larva & 1 & 1 & 1.7 \\
\hline Insecta & Lepidoptera & Tineidae & Clothes Moths & Adult & 1 & 1 & 0.8 \\
\hline Insecta & Lepidoptera & Tortricidae & Leafrolling Moths & Adult & 1 & 1 & 1.4 \\
\hline Insecta & Neuroptera & Chrysopidae & Common Lacewings & Larva & 1 & 1 & 0.2 \\
\hline Insecta & Orthoptera & Tettigoniidae & Katydids & Adult & 1 & 1 & 3.1 \\
\hline Malacostraca & Isopoda & Porcellionidae & Sowbug & Adult & 1 & 1 & 1.1 \\
\hline
\end{tabular}


Appendix IXb. Abundance, frequency, and total biomass (mg) of 71 invertebrate groups sampled in the understory of 45 lone southern arrowwood shrubs at Fort Necessity National Battlefield, Pennsylvania, U.S.A. during July 2004 and May \& August 2005.

\begin{tabular}{|c|c|c|c|c|c|c|c|}
\hline Class & Order & Taxonomic group & Common name & Stage & Abundance & Frequency & Total biomass $(\mathrm{mg})$ \\
\hline Insecta & Homoptera & Cicadellidae & Leafhoppers & Adult & 160 & 36 & 83.4 \\
\hline Insecta & Collembola & Isotomidae & Springtails & Adult & 145 & 29 & 12.7 \\
\hline Insecta & Hymenoptera & Formicidae & Ants & Adult & 67 & 27 & 17.7 \\
\hline Insecta & Coleoptera & Curculionidae & Snout Beetles & Adult & 28 & 18 & 23.3 \\
\hline Arachnida & Araneae & Lycosidae & Wolf Spiders & Adult & 28 & 14 & 39.9 \\
\hline Arachnida & Araneae & Salticidae & Jumping Spiders & Adult & 17 & 10 & 13.7 \\
\hline Diplopoda & $\mathrm{N} / \mathrm{A}$ & Diplopoda & Millipedes & Adult & 16 & 7 & 7.9 \\
\hline Insecta & Hymenoptera & Braconidae & Braconids & Adult & 15 & 11 & 3.4 \\
\hline Insecta & Diptera & Sciaridae & Dark-winged Fungus Gnats & Adult & 15 & 5 & 2.6 \\
\hline Insecta & Homoptera & Psyllidae & Jumping Plantlice & Adult & 13 & 9 & 4.3 \\
\hline Arachnida & Araneae & Araneidae & Orb Weavers & Adult & 10 & 10 & 5.6 \\
\hline Insecta & Coleoptera & Chrysomelidae & Leaf Beetles & Adult & 10 & 9 & 48.1 \\
\hline Gastropoda & Stylommatophora & Stylommatophora & Land Snails and Slugs & Adult & 9 & 8 & 50.6 \\
\hline Insecta & Coleoptera & Staphylinidae & Rove Beetles & Adult & 9 & 8 & 19.0 \\
\hline Insecta & Hymenoptera & Scelionidae & Scelionid Wasps & Adult & 9 & 8 & 1.4 \\
\hline Insecta & Hemiptera & Lygaeidae & Seed Bugs & Adult & 9 & 6 & 23.9 \\
\hline Arachnida & Opiliones & Phalangiidae & Harvestmen & Adult & 7 & 6 & 71.9 \\
\hline Chilopoda & $\mathrm{N} / \mathrm{A}$ & Chilopoda & Centipedes & Adult & 7 & 6 & 6.1 \\
\hline Insecta & Hymenoptera & Symphyta & Sawflies and Horntails & Larva & 7 & 6 & 11.1 \\
\hline
\end{tabular}


Appendix IXb. Continued.

\begin{tabular}{|c|c|c|c|c|c|c|c|}
\hline Class & Order & Taxonomic group & Common name & Stage & Abundance & Frequency & Total biomass $(\mathrm{mg})$ \\
\hline Insecta & Lepidoptera & Noctuidae & Noctuids & Larva & 6 & 5 & 27.8 \\
\hline Insecta & Hemiptera & Pentatomidae & Stink Bugs & Adult & 6 & 4 & 30.4 \\
\hline Insecta & Coleoptera & Coccinellidae & Ladybugs & Larva & 6 & 3 & 0.3 \\
\hline Insecta & Coleoptera & Chrysomelidae & Leaf Beetles & Larva & 5 & 3 & 0.3 \\
\hline Insecta & Hemiptera & Miridae & Plant Bugs & Adult & 5 & 3 & 2.0 \\
\hline Insecta & Homoptera & Derbidae & Planthoppers & Adult & 5 & 3 & 4.2 \\
\hline Arachnida & Araneae & Clubionidae & Two-clawed Hunting Spiders & Adult & 4 & 4 & 12.1 \\
\hline Insecta & Homoptera & Delphacidae & Planthoppers & Adult & 4 & 4 & 1.3 \\
\hline Malacostraca & Isopoda & Porcellionidae & Sowbug & Adult & 4 & 4 & 2.5 \\
\hline Insecta & Diptera & Tipulidae & Crane Flies & Adult & 4 & 3 & 2.5 \\
\hline Insecta & Lepidoptera & Gracillariidae & Leafblotch Miners & Adult & 4 & 3 & 2.0 \\
\hline Arachnida & Araneae & Gnaphosidae & Sac Spiders & Adult & 3 & 3 & 3.8 \\
\hline Arachnida & Araneae & Theridiidae & Comb-footed Spiders & Adult & 3 & 3 & 1.9 \\
\hline Insecta & Coleoptera & Mordellidae & Tumbling Flower Beetles & Adult & 3 & 3 & 2.5 \\
\hline Insecta & Coleoptera & Staphylinidae & Rove Beetles & Larva & 3 & 3 & 0.3 \\
\hline Insecta & Diptera & Dolichopodidae & Long-legged Flies & Adult & 3 & 3 & 0.5 \\
\hline Insecta & Diptera & Muscidae & House Flies and Allies & Adult & 3 & 3 & 2.7 \\
\hline Insecta & Hemiptera & Reduviidae & Assasin Bugs & Adult & 3 & 3 & 0.8 \\
\hline Insecta & Diptera & Chironomidae & Midges & Adult & 3 & 2 & 1.9 \\
\hline Arachnida & Araneae & Thomasidae & Crab Spiders & Adult & 2 & 2 & 2.5 \\
\hline
\end{tabular}


Appendix IXb. Continued.

\begin{tabular}{|c|c|c|c|c|c|c|c|}
\hline Class & Order & Taxonomic group & Common name & Stage & Abundance & Frequency & Total biomass ( $\mathrm{mg}$ ) \\
\hline Insecta & Coleoptera & Coccinellidae & Ladybugs & Adult & 2 & 2 & 1.9 \\
\hline Insecta & Diptera & Drosophilidae & Small Fruit Flies & Adult & 2 & 2 & 0.6 \\
\hline Insecta & Diptera & Empididae & Dance Flies & Adult & 2 & 2 & 0.7 \\
\hline Insecta & Hemiptera & Nabidae & Damsel Bugs & Adult & 2 & 2 & 1.3 \\
\hline Insecta & Homoptera & Aphididae & Aphids & Adult & 2 & 2 & 0.5 \\
\hline Insecta & Homoptera & Membracidae & Treehoppers & Adult & 2 & 2 & 2.7 \\
\hline Insecta & Orthoptera & Acrididae & Short-horned Grasshoppers & Adult & 2 & 2 & 27.6 \\
\hline Insecta & Diptera & Simuliidae & Black Flies & Adult & 2 & 1 & 0.6 \\
\hline Arachnida & Araneae & Agelenidae & Funnel Weavers & Adult & 1 & 1 & 19.1 \\
\hline Arachnida & Araneae & Amaurobiidae & Blue Silk Spiders & Adult & 1 & 1 & 3.7 \\
\hline Arachnida & Araneae & Anyphaenidae & Buzzing Spiders & Adult & 1 & 1 & 1.0 \\
\hline Arachnida & Araneae & Linyphiidae & Sheet-web Spiders & Adult & 1 & 1 & 0.2 \\
\hline Insecta & Coleoptera & Cleridae & Checkered Beetles & Adult & 1 & 1 & 1.7 \\
\hline Insecta & Coleoptera & Lampyridae & Lightningbugs & Adult & 1 & 1 & 0.6 \\
\hline Insecta & Coleoptera & Melandryidae & False Darkling Beetles & Adult & 1 & 1 & 0.2 \\
\hline Insecta & Coleoptera & Phalacridae & Shining Fungus Beetles & Adult & 1 & 1 & 0.3 \\
\hline Insecta & Coleoptera & Tenebrionidae & Darkling Beetles & Adult & 1 & 1 & 3.6 \\
\hline Insecta & Diptera & Diptera & Flies & Puparia & 1 & 1 & $\mathrm{~N} / \mathrm{A}$ \\
\hline Insecta & Diptera & Heleomyzidae & Heleomyzid Flies & Adult & 1 & 1 & 0.2 \\
\hline Insecta & Diptera & Sphaeroceridae & Small Dung Flies & Adult & 1 & 1 & 0.7 \\
\hline
\end{tabular}


Appendix IXb. Continued.

\begin{tabular}{|c|c|c|c|c|c|c|c|}
\hline Class & Order & Taxonomic group & Common name & Stage & Abundance & Frequency & Total biomass ( $\mathrm{mg})$ \\
\hline Insecta & Diptera & Syrphidae & Flower Flies & Adult & 1 & 1 & 1.4 \\
\hline Insecta & Hemiptera & Tingidae & Lace Bugs & Adult & 1 & 1 & 0.1 \\
\hline Insecta & Hymenoptera & Cynipidae & Gall Wasps & Adult & 1 & 1 & 0.1 \\
\hline Insecta & Hymenoptera & Ichneumonidae & Ichneumons & Adult & 1 & 1 & 1.4 \\
\hline Insecta & Hymenoptera & Tenthredinidae & Sawflies & Adult & 1 & 1 & 1.7 \\
\hline Insecta & Lepidoptera & Arctiidae & Tiger Moths & Larva & 1 & 1 & 2.5 \\
\hline Insecta & Lepidoptera & Lepidoptera & Moth & Puparia & 1 & 1 & N/A \\
\hline Insecta & Lepidoptera & Noctuidae & Noctuids & Adult & 1 & 1 & 11.1 \\
\hline Insecta & Lepidoptera & Pyralidae & Snout Moths & Adult & 1 & 1 & 2.1 \\
\hline Insecta & Lepidoptera & Pyralidae & Snout Moths & Larva & 1 & 1 & 14.1 \\
\hline Insecta & Lepidoptera & Tineidae & Clothes Moths & Adult & 1 & 1 & 0.1 \\
\hline Insecta & Lepidoptera & Tineidae & Clothes Moths & Larva & 1 & 1 & 0.1 \\
\hline Insecta & Lepidoptera & Tortricidae & Leafrolling Moths & Larva & 1 & 1 & 0.1 \\
\hline Insecta & Neuroptera & Chrysopidae & Common Lacewings & Larva & 1 & 1 & 0.1 \\
\hline Insecta & Psocoptera & Polypsocidae & Bark Lice & Adult & 1 & 1 & 0.2 \\
\hline Insecta & Thysanoptera & Phlaeothripidae & Thrips & Adult & 1 & 1 & 0.1 \\
\hline
\end{tabular}


Appendix Xb. Abundance, frequency, and total biomass (mg) of 67 invertebrate groups sampled in the understory of 45 dense thickets of Morrow's honeysuckle shrubs at Fort Necessity National Battlefield, Pennsylvania, U.S.A. during July 2004 and May \& August 2005.

\begin{tabular}{|c|c|c|c|c|c|c|c|}
\hline Class & Order & Taxonomic group & Common name & Stage & Abundance & Frequency & Total biomass ( $\mathrm{mg}$ ) \\
\hline Insecta & Collembola & Isotomidae & Springtails & Adult & 106 & 28 & 8.1 \\
\hline Insecta & Homoptera & Cicadellidae & Leafhoppers & Adult & 44 & 18 & 20.0 \\
\hline Insecta & Hymenoptera & Formicidae & Ants & Adult & 38 & 17 & 11.6 \\
\hline Insecta & Coleoptera & Curculionidae & Snout Beetles & Adult & 23 & 14 & 30.8 \\
\hline Insecta & Diptera & Sciaridae & Dark-winged Fungus Gnats & Adult & 17 & 6 & 3.8 \\
\hline Gastropoda & Stylommatophora & Stylommatophora & Land Snails and Slugs & Adult & 13 & 12 & 72.1 \\
\hline Arachnida & Araneae & Lycosidae & Wolf Spiders & Adult & 12 & 6 & 6.4 \\
\hline Arachnida & Araneae & Salticidae & Jumping Spiders & Adult & 9 & 8 & 6.9 \\
\hline Insecta & Hemiptera & Lygaeidae & Seed Bugs & Adult & 9 & 8 & 0.7 \\
\hline Insecta & Lepidoptera & Noctuidae & Noctuids & Larva & 9 & 8 & 10.7 \\
\hline Insecta & Hemiptera & Pentatomidae & Stink Bugs & Adult & 9 & 7 & 85.0 \\
\hline Insecta & Diptera & Simuliidae & Black Flies & Adult & 8 & 4 & 2.4 \\
\hline Insecta & Coleoptera & Staphylinidae & Rove Beetles & Adult & 7 & 6 & 15.1 \\
\hline Diplopoda & $\mathrm{N} / \mathrm{A}$ & Diplopoda & Millipedes & Adult & 7 & 5 & 0.2 \\
\hline Insecta & Diptera & Diptera & Flies & Puparia & 6 & 4 & $\mathrm{~N} / \mathrm{A}$ \\
\hline Arachnida & Araneae & Araneidae & Orb Weavers & Adult & 5 & 5 & 2.6 \\
\hline Insecta & Hymenoptera & Braconidae & Braconids & Adult & 5 & 5 & 2.9 \\
\hline
\end{tabular}


Appendix Xb. Continued.

\begin{tabular}{|c|c|c|c|c|c|c|c|}
\hline Class & Order & Taxonomic group & Common name & Stage & Abundance & Frequency & Total biomass ( $\mathrm{mg}$ \\
\hline Insecta & Diptera & Dolichopodidae & Long-legged Flies & Adult & 5 & 4 & 1.0 \\
\hline Insecta & Collembola & Hypogastruridae & Springtails & Adult & 5 & 1 & 0.7 \\
\hline Insecta & Homoptera & Psyllidae & Jumping Plantlice & Adult & 4 & 3 & 1.4 \\
\hline Arachnida & Araneae & Clubionidae & Two-clawed Hunting Spiders & Adult & 3 & 3 & 2.7 \\
\hline Insecta & Coleoptera & Carabidae & Ground Beetles & Adult & 3 & 3 & 1.7 \\
\hline Insecta & Coleoptera & Chrysomelidae & Leaf Beetles & Adult & 3 & 3 & 16.9 \\
\hline Insecta & Diptera & Drosophilidae & Small Fruit Flies & Adult & 3 & 3 & 0.8 \\
\hline Insecta & Hymenoptera & Scelionidae & Scelionid Wasps & Adult & 3 & 3 & 0.3 \\
\hline Insecta & Diptera & Syrphidae & Flower Flies & Larva & 3 & 2 & 2.6 \\
\hline Insecta & Diptera & Tephritidae & Fruit Flies & Adult & 3 & 2 & 2.5 \\
\hline Insecta & Homoptera & Delphacidae & Planthoppers & Adult & 3 & 2 & 1.0 \\
\hline Chilopoda & N/A & Chilopoda & Centipedes & Adult & 2 & 2 & 0.1 \\
\hline Insecta & Coleoptera & Erotylidae & Pleasing Fungus Beetles & Adult & 2 & 2 & 0.6 \\
\hline Insecta & Collembola & Sminthuridae & Springtails & Adult & 2 & 2 & 0.1 \\
\hline Insecta & Diptera & Heleomyzidae & Heleomyzid Flies & Adult & 2 & 2 & 0.6 \\
\hline Insecta & Diptera & Mycetophilidae & Fungus Gnats & Adult & 2 & 2 & 0.7 \\
\hline Insecta & Hemiptera & Reduviidae & Assasin Bugs & Adult & 2 & 2 & 1.5 \\
\hline Insecta & Lepidoptera & Gelechiidae & Gelechiid Moths & Larva & 2 & 2 & 2.2 \\
\hline Insecta & Diptera & Sciaridae & Dark-winged Fungus Gnats & Larva & 2 & 1 & 0.1 \\
\hline Arachnida & Araneae & Agelenidae & Funnel Weavers & Adult & 1 & 1 & 2.8 \\
\hline
\end{tabular}


Appendix Xb. Continued.

\begin{tabular}{|c|c|c|c|c|c|c|c|}
\hline Class & Order & Taxonomic group & Common name & Stage & Abundance & Frequency & Total biomass $(\mathrm{mg})$ \\
\hline Arachnida & Araneae & Theridiidae & Comb-footed Spiders & Adult & 1 & 1 & 0.3 \\
\hline Arachnida & Araneae & Thomasidae & Crab Spiders & Adult & 1 & 1 & 17.7 \\
\hline Arachnida & Opiliones & Phalangiidae & Harvestmen & Adult & 1 & 1 & 14.4 \\
\hline Insecta & Coleoptera & Chrysomelidae & Leaf Beetles & Larva & 1 & 1 & 0.0 \\
\hline Insecta & Coleoptera & Coccinellidae & Ladybugs & Adult & 1 & 1 & 0.3 \\
\hline Insecta & Coleoptera & Lathridiidae & Minute Brown Scavenger Beetles & Larva & 1 & 1 & 0.1 \\
\hline Insecta & Coleoptera & Staphylinidae & Rove Beetles & Larva & 1 & 1 & 0.2 \\
\hline Insecta & Diptera & Anthomyiidae & Anthomyiid Flies & Larva & 1 & 1 & 2.1 \\
\hline Insecta & Diptera & Chloropidae & Grass Flies & Adult & 1 & 1 & 0.2 \\
\hline Insecta & Diptera & Empididae & Dance Flies & Adult & 1 & 1 & 0.2 \\
\hline Insecta & Diptera & Muscidae & House Flies and Allies & Adult & 1 & 1 & 1.5 \\
\hline Insecta & Diptera & Pipunculidae & Big-headed Flies & Adult & 1 & 1 & 0.5 \\
\hline Insecta & Diptera & Sepsidae & Black Scavenger Flies & Adult & 1 & 1 & 0.5 \\
\hline Insecta & Hemiptera & Enicocephalidae & Unique-headed Bugs & Adult & 1 & 1 & 0.4 \\
\hline Insecta & Hemiptera & Miridae & Plant Bugs & Adult & 1 & 1 & 0.5 \\
\hline Insecta & Hemiptera & Nabidae & Damsel Bugs & Adult & 1 & 1 & 0.7 \\
\hline Insecta & Hemiptera & Piesmatidae & Ash-Gray Leaf Bugs & Adult & 1 & 1 & 0.1 \\
\hline Insecta & Hemiptera & Tingidae & Lace Bugs & Adult & 1 & 1 & 0.1 \\
\hline Insecta & Homoptera & Derbidae & Planthoppers & Adult & 1 & 1 & 0.6 \\
\hline Insecta & Hymenoptera & Hymenoptera & Wasps, Ants, Bees & Puparia & 1 & 1 & $\mathrm{~N} / \mathrm{A}$ \\
\hline
\end{tabular}


Appendix Xb. Continued.

\begin{tabular}{|c|c|c|c|c|c|c|c|}
\hline Class & Order & Taxonomic group & Common name & Stage & Abundance & Frequency & Total biomass $(\mathrm{mg})$ \\
\hline Insecta & Hymenoptera & Ichneumonidae & Ichneumons & Adult & 1 & 1 & 0.3 \\
\hline Insecta & Hymenoptera & Mutillidae & Velvet Ants & Adult & 1 & 1 & 0.3 \\
\hline Insecta & Hymenoptera & Sphecidae & Cicada Killers, Mud Daubers, \& Sand Wasps & Adult & 1 & 1 & 1.0 \\
\hline Insecta & Hymenoptera & Symphyta & Sawflies and Horntails & Larva & 1 & 1 & 0.1 \\
\hline Insecta & Lepidoptera & Arctiidae & Tiger Moths & Larva & 1 & 1 & 1.8 \\
\hline Insecta & Lepidoptera & Geometridae & Measuringworms & Adult & 1 & 1 & 16.6 \\
\hline Insecta & Lepidoptera & Geometridae & Measuringworms & Larva & 1 & 1 & 3.0 \\
\hline Insecta & Lepidoptera & Lyonetiidae & A Moth & Adult & 1 & 1 & 0.4 \\
\hline Insecta & Lepidoptera & Psychidae & Bagworm Moths & Adult & 1 & 1 & 1.7 \\
\hline Insecta & Lepidoptera & Tineidae & Clothes Moths & Adult & 1 & 1 & 0.1 \\
\hline Insecta & Neuroptera & Chrysopidae & Common Lacewings & Larva & 1 & 1 & 0.3 \\
\hline Insecta & Neuroptera & Hemerobiidae & Brown Lacewings & Adult & 1 & 1 & 0.1 \\
\hline Insecta & Neuroptera & Hemerobiidae & Brown Lacewings & Larva & 1 & 1 & 2.2 \\
\hline Insecta & Psocoptera & Pseudocaeciliidae & Bark Lice & Adult & 1 & 1 & 0.1 \\
\hline
\end{tabular}


Appendix XIb. Abundance, frequency, and total biomass (mg) of 62 invertebrate groups sampled in the understory of 45 open plots with no overstory at Fort Necessity National Battlefield, Pennsylvania, U.S.A. during July 2004 and May \& August 2005.

\begin{tabular}{|c|c|c|c|c|c|c|c|}
\hline Class & Order & Taxonomic group & Common name & Stage & Abundance & Frequency & Total biomass (mg) \\
\hline Insecta & Homoptera & Cicadellidae & Leafhoppers & Adult & 195 & 37 & 97.7 \\
\hline Insecta & Collembola & Isotomidae & Springtails & Adult & 152 & 31 & 8.4 \\
\hline Insecta & Hymenoptera & Formicidae & Ants & Adult & 70 & 21 & 37.2 \\
\hline Insecta & Coleoptera & Chrysomelidae & Leaf Beetles & Larva & 54 & 10 & 4.0 \\
\hline Insecta & Homoptera & Psyllidae & Jumping Plantlice & Adult & 44 & 16 & 15.2 \\
\hline Arachnida & Araneae & Lycosidae & Wolf Spiders & Adult & 31 & 16 & 65.6 \\
\hline Insecta & Hemiptera & Miridae & Plant Bugs & Adult & 13 & 11 & 7.7 \\
\hline Insecta & Diptera & Drosophilidae & Small Fruit Flies & Adult & 13 & 7 & 3.2 \\
\hline Insecta & Coleoptera & Curculionidae & Snout Beetles & Adult & 11 & 7 & 8.7 \\
\hline Insecta & Lepidoptera & Noctuidae & Noctuids & Larva & 10 & 5 & 38.8 \\
\hline Arachnida & Araneae & Salticidae & Jumping Spiders & Adult & 9 & 7 & 5.9 \\
\hline Insecta & Hymenoptera & Formicidae & Ants & Larva & 9 & 1 & 7.4 \\
\hline Insecta & Hymenoptera & Scelionidae & Scelionid Wasps & Adult & 8 & 8 & 1.3 \\
\hline Insecta & Diptera & Sciaridae & Dark-winged Fungus Gnats & Adult & 8 & 7 & 1.2 \\
\hline Gastropoda & Stylommatophora & Stylommatophora & Land Snails and Slugs & Adult & 7 & 7 & 45.4 \\
\hline Insecta & Homoptera & Delphacidae & Planthoppers & Adult & 7 & 6 & 3.3 \\
\hline Insecta & Hymenoptera & Braconidae & Braconids & Adult & 6 & 6 & 2.5 \\
\hline Arachnida & Opiliones & Phalangiidae & Harvestmen & Adult & 6 & 4 & 25.5 \\
\hline Insecta & Coleoptera & Chrysomelidae & Leaf Beetles & Adult & 6 & 4 & 11.7 \\
\hline
\end{tabular}


Appendix XIb. Continued.

\begin{tabular}{|c|c|c|c|c|c|c|c|}
\hline Class & Order & Taxonomic group & Common name & Stage & Abundance & Frequency & Total biomass $(\mathrm{mg})$ \\
\hline Insecta & Homoptera & Cercopidae & Spittlebugs & Adult & 5 & 4 & 16.5 \\
\hline Insecta & Hemiptera & Nabidae & Damsel Bugs & Adult & 5 & 3 & 2.4 \\
\hline Insecta & Hymenoptera & Chalcidoidea & Chalcids & Larva & 5 & 1 & 0.7 \\
\hline Arachnida & Araneae & Araneidae & Orb Weavers & Adult & 4 & 4 & 2.4 \\
\hline Arachnida & Araneae & Clubionidae & Two-clawed Hunting Spiders & Adult & 4 & 4 & 15.6 \\
\hline Insecta & Diptera & Heleomyzidae & Heleomyzid Flies & Adult & 4 & 4 & 0.8 \\
\hline Insecta & Hemiptera & Reduviidae & Assasin Bugs & Adult & 4 & 4 & 2.6 \\
\hline Insecta & Coleoptera & Bruchidae & Seed Beetles & Adult & 3 & 3 & 1.7 \\
\hline Insecta & Diptera & Chloropidae & Grass Flies & Adult & 3 & 3 & 0.9 \\
\hline Insecta & Hemiptera & Pentatomidae & Stink Bugs & Adult & 3 & 3 & 21.6 \\
\hline Insecta & Homoptera & Aphididae & Aphids & Adult & 3 & 3 & 0.8 \\
\hline Insecta & Collembola & Hypogastruridae & Springtails & Adult & 3 & 2 & 0.5 \\
\hline Insecta & Diptera & Dolichopodidae & Long-legged Flies & Adult & 3 & 2 & 0.5 \\
\hline Insecta & Diptera & Empididae & Dance Flies & Adult & 3 & 2 & 0.6 \\
\hline Insecta & Diptera & Syrphidae & Flower Flies & Larva & 3 & 2 & 2.7 \\
\hline Insecta & Hymenoptera & Symphyta & Sawflies and Horntails & Larva & 3 & 2 & 10.8 \\
\hline Chilopoda & $\mathrm{N} / \mathrm{A}$ & Chilopoda & Centipedes & Adult & 2 & 2 & 0.2 \\
\hline Diplopoda & $\mathrm{N} / \mathrm{A}$ & Diplopoda & Millipedes & Adult & 2 & 2 & 0.1 \\
\hline Insecta & Coleoptera & Staphylinidae & Rove Beetles & Adult & 2 & 2 & 2.0 \\
\hline
\end{tabular}


Appendix XIb. Continued.

\begin{tabular}{|c|c|c|c|c|c|c|c|}
\hline Class & Order & Taxonomic group & Common name & Stage & Abundance & Frequency & Total biomass $(\mathrm{mg})$ \\
\hline Insecta & Diptera & Chironomidae & Midges & Adult & 2 & 2 & 0.6 \\
\hline Insecta & Hemiptera & Lygaeidae & Seed Bugs & Adult & 2 & 2 & 0.2 \\
\hline Insecta & Orthoptera & Acrididae & Short-horned Grasshoppers & Adult & 2 & 2 & 13.1 \\
\hline Insecta & Orthoptera & Tettigoniidae & Katydids & Adult & 2 & 2 & 17.6 \\
\hline Insecta & Coleoptera & Phalacridae & Shining Fungus Beetles & Adult & 2 & 1 & 0.6 \\
\hline Arachnida & Acari & Trombidioidea & Mites & Adult & 1 & 1 & 0.3 \\
\hline Arachnida & Araneae & Gnaphosidae & Sac Spiders & Adult & 1 & 1 & 0.6 \\
\hline Arachnida & Araneae & Oxyopidae & Lynx Spiders & Adult & 1 & 1 & 1.7 \\
\hline Arachnida & Araneae & Thomasidae & Crab Spiders & Adult & 1 & 1 & 0.5 \\
\hline Insecta & Coleoptera & Byrrhidae & Pill Beetles & Adult & 1 & 1 & 1.2 \\
\hline Insecta & Coleoptera & Carabidae & Ground Beetles & Adult & 1 & 1 & 0.2 \\
\hline Insecta & Coleoptera & Elateridae & Click Beetles & Larva & 1 & 1 & 0.4 \\
\hline Insecta & Diptera & Cecidomyiidae & Gall Midges & Larva & 1 & 1 & 0.2 \\
\hline Insecta & Diptera & Diptera & Flies & Puparia & 1 & 1 & $\mathrm{~N} / \mathrm{A}$ \\
\hline Insecta & Diptera & Tephritidae & Fruit Flies & Adult & 1 & 1 & 0.5 \\
\hline Insecta & Homoptera & Cixiidae & Planthoppers & Adult & 1 & 1 & 1.0 \\
\hline Insecta & Homoptera & Derbidae & Planthoppers & Adult & 1 & 1 & 1.8 \\
\hline Insecta & Hymenoptera & Eurytomidae & Eurytomids, Jointworms, \& Seed Chalcids & Adult & 1 & 1 & 0.2 \\
\hline Insecta & Lepidoptera & Arctiidae & Tiger Moths & Larva & 1 & 1 & 0.1 \\
\hline Insecta & Lepidoptera & Gelechiidae & Gelechiid Moths & Larva & 1 & 1 & 0.5 \\
\hline
\end{tabular}


Appendix XIb. Continued.

\begin{tabular}{|c|c|c|c|c|c|c|c|}
\hline Class & Order & Taxonomic group & Common name & Stage & Abundance & Frequency & Total biomass $(\mathrm{mg})$ \\
\hline Insecta & Lepidoptera & Gracillariidae & Leafblotch Miners & Adult & 1 & 1 & 0.8 \\
\hline Insecta & Lepidoptera & Noctuidae & Noctuids & Adult & 1 & 1 & 20.9 \\
\hline Insecta & Lepidoptera & Pyralidae & Snout Moths & Adult & 1 & 1 & 3.5 \\
\hline Insecta & Mecoptera & Panorpidae & Common Scorpionflies & Adult & 1 & 1 & 4.0 \\
\hline Insecta & Orthoptera & Gryllacrididae & Wingless Long-horned Grasshoppers & Adult & 1 & 1 & 4.1 \\
\hline Insecta & Orthoptera & Tetrigidae & Pygmy Grasshoppers & Adult & 1 & 1 & 1.4 \\
\hline Malacostraca & Isopoda & Porcellionidae & Sowbug & Adult & 1 & 1 & 3.4 \\
\hline
\end{tabular}


Appendix XIIb. $F$ and $p$ values of abundance, biomass, and richness of invertebrates $(\geq 2 \mathrm{~mm}$ in length) sampled in the understory below four shrub types during three different months at Fort Necessity National Battlefield, Pennsylvania, U.S.A.

\begin{tabular}{|c|c|c|c|c|c|c|}
\hline \multirow[b]{3}{*}{ Dependent variables } & \multicolumn{6}{|c|}{ Independent variables } \\
\hline & \multicolumn{2}{|c|}{ Shrub type } & \multicolumn{2}{|c|}{ Month } & \multicolumn{2}{|c|}{ Shrub type $\times$ month } \\
\hline & $\mathrm{F}_{[3,168]}$ & $\mathrm{p}$ & $\mathrm{F}_{[2,168]}$ & $\mathrm{p}$ & $\mathrm{F}_{[6,168]}$ & $\mathrm{p}$ \\
\hline Abundance & 10.03 & $<0.001$ & 23.81 & $<0.001$ & 3.19 & 0.006 \\
\hline Biomass & 5.75 & $<0.001$ & 0.75 & 0.476 & 1.72 & 0.118 \\
\hline Richness & 7.99 & $<0.001$ & 13.84 & $<0.001$ & 3.02 & 0.008 \\
\hline
\end{tabular}


Appendix XIIIb. Mean ( \pm SE) abundance, biomass, and richness of invertebrates $(\geq 2 \mathrm{~mm}$ in length) sampled in the understory based on shrub type and season combinations at Fort Necessity National Battlefield, Pennsylvania, U.S.A.

\begin{tabular}{|c|c|c|c|c|}
\hline Variable & $n$ & $\begin{array}{c}\text { Abundance } \\
\bar{X} \pm S E^{\mathrm{ab}}\end{array}$ & $\begin{array}{c}\text { Biomass (mg) } \\
\bar{X} \pm S E^{\mathrm{c}}\end{array}$ & $\begin{array}{l}\text { Richness } \\
\bar{X} \pm S E^{\mathrm{d}} \\
\end{array}$ \\
\hline \multicolumn{5}{|c|}{ Lone Morrow's honeysuckle shrubs } \\
\hline May & 15 & $22.0 \pm 1.7 \mathrm{~A}$ & $13.0 \pm 2.3 \mathrm{ABC}$ & $8.3 \pm 0.5 \mathrm{AB}$ \\
\hline July & 15 & $16.4 \pm 1.2 \mathrm{AB}$ & $12.1 \pm 1.5 \mathrm{AB}$ & $8.5 \pm 0.5 \mathrm{~A}$ \\
\hline August & 15 & $9.1 \pm 1.1 \mathrm{CD}$ & $18.5 \pm 5.5 \mathrm{AB}$ & $6.3 \pm 0.8 \mathrm{BCDE}$ \\
\hline \multicolumn{5}{|c|}{ Lone southern arrowwood shrubs } \\
\hline May & 15 & $22.5 \pm 2.1 \mathrm{~A}$ & $13.5 \pm 1.4 \mathrm{~A}$ & $9.4 \pm 0.6 \mathrm{~A}$ \\
\hline July & 15 & $13.9 \pm 1.3 \mathrm{BC}$ & $10.9 \pm 1.6 \mathrm{ABCD}$ & $7.1 \pm 0.7 \mathrm{ABCD}$ \\
\hline August & 15 & $10.5 \pm 1.4 \mathrm{CD}$ & $19.1 \pm 4.4 \mathrm{~A}$ & $6.1 \pm 0.8 \mathrm{CDE}$ \\
\hline \multicolumn{5}{|c|}{ Dense thickets of Morrow's honeysuckle } \\
\hline May & 15 & $9.0 \pm 1.4 \mathrm{CD}$ & $8.1 \pm 1.5 \mathrm{ABCD}$ & $4.7 \pm 0.4 \mathrm{EF}$ \\
\hline July & 15 & $9.7 \pm 2.0 \mathrm{CD}$ & $9.8 \pm 4.5 \mathrm{BCD}$ & $5.9 \pm 0.7 \mathrm{CDE}$ \\
\hline August & 15 & $9.1 \pm 2.3 \mathrm{D}$ & $7.9 \pm 2.6 \mathrm{CD}$ & $5.3 \pm 0.8 \mathrm{EF}$ \\
\hline \multicolumn{5}{|c|}{ Open plots with no overstory } \\
\hline May & 15 & $20.9 \pm 3.4 \mathrm{AB}$ & $11.8 \pm 2.9 \mathrm{~A}$ & $7.9 \pm 0.7 \mathrm{ABC}$ \\
\hline July & 15 & $20.7 \pm 3.5 \mathrm{AB}$ & $17.9 \pm 4.5 \mathrm{~A}$ & $7.8 \pm 0.9 \mathrm{ABC}$ \\
\hline August & 15 & $8.7 \pm 2.4 \mathrm{D}$ & $7.2 \pm 2.2 \mathrm{D}$ & $3.9 \pm 0.7 \mathrm{~F}$ \\
\hline
\end{tabular}

${ }^{a}$ Means in columns with different letters are significantly different $(p<0.05)$, based on Duncan's multiple range tests.

${ }^{\mathrm{b}} F_{[11,168]}=8.80, p<0.001$

${ }^{\mathrm{c}} F_{[11,168]}=2.64, p=0.004$

${ }^{\mathrm{d}} F_{[11,168]}=6.34, p<0.001$ 
Appendix XIVb. Mean ( \pm SE) values of microhabitat variables recorded under Morrow’s honeysuckle shrubs (L), southern arrowwood shrubs (V), dense thickets of Morrow's honeysuckle (X), and open plots with no shrub cover (O) at Fort Necessity National Battlefield, Pennsylvania, U.S.A.

\begin{tabular}{lcccc}
\hline & \multicolumn{4}{c}{ Shrub type $^{\mathrm{c}}$} \\
\cline { 2 - 5 } Microhabitat variables ${ }^{\mathrm{a}, \mathrm{b}}$ & $L$ & $\bar{X} \pm S E$ & $\bar{X} \pm S E$ & $\bar{X} \pm S E$ \\
\cline { 2 - 5 } Herb richness & $\bar{X} \pm S E$ & $5.8 \pm 0.4$ & $5.6 \pm 0.3$ & $7.3 \pm 0.5$ \\
Total herb cover (\%) & $72.7 \pm 5.7 \mathrm{~B}$ & $72.8 \pm 5.4 \mathrm{~B}$ & $44.1 \pm 4.0 \mathrm{C}$ & $105.3 \pm 6.5 \mathrm{~A}$ \\
Native cover: total cover (\%) & $61.8 \pm 3.6 \mathrm{~B}$ & $71.1 \pm 3.3 \mathrm{~A}$ & $51.5 \pm 3.9 \mathrm{~B}$ & $72.8 \pm 3.3 \mathrm{~A}$ \\
Litter N (\%) & $1.22 \pm 0.06 \mathrm{BC}$ & $1.44 \pm 0.06 \mathrm{~A}$ & $1.38 \pm 0.07 \mathrm{AB}$ & $1.17 \pm 0.04 \mathrm{C}$ \\
Litter Ca (\%) & $0.80 \pm 0.04$ & $0.87 \pm 0.03$ & $0.99 \pm 0.05$ & $0.76 \pm 0.04$ \\
Litter P (\%) & $0.075 \pm 0.004$ & $0.092 \pm 0.005$ & $0.094 \pm 0.007$ & $0.068 \pm 0.002$ \\
Litter Mg (\%) & $0.067 \pm 0.004$ & $0.080 \pm 0.004$ & $0.069 \pm 0.004$ & $0.068 \pm 0.004$ \\
Litter K (\%) & $0.15 \pm 0.01$ & $0.18 \pm 0.03$ & $0.16 \pm 0.01$ & $0.15 \pm 0.01$ \\
Dry litter wt. (g) & $17.88 \pm 1.96 \mathrm{BC}$ & $31.63 \pm 2.86 \mathrm{~A}$ & $17.57 \pm 2.11 \mathrm{C}$ & $25.18 \pm 2.82 \mathrm{AB}$ \\
Wet debris wt. (g) & $1.91 \pm 0.21 \mathrm{~B}$ & $2.14 \pm 0.25 \mathrm{~B}$ & $3.88 \pm 0.44 \mathrm{~A}$ & $1.68 \pm 0.25 \mathrm{~B}$ \\
Soil moisture (\%) & $19.5 \pm 0.8 \mathrm{~A}$ & $20.4 \pm 0.8 \mathrm{~A}$ & $19.9 \pm 0.8 \mathrm{~A}$ & $19.5 \pm 1.0 \mathrm{~A}$ \\
Soil temp. $\left({ }^{\circ} \mathrm{C}\right)$ & $20.7 \pm 0.7 \mathrm{~A}$ & $20.6 \pm 0.6 \mathrm{~A}$ & $19.9 \pm 0.6 \mathrm{~A}$ & $21.9 \pm 0.7 \mathrm{~A}$ \\
\hline
\end{tabular}

${ }^{\text {a }}$ For all microhabitat variables - shrub types, $n=45$, except for: wet debris wt. $(\mathrm{L}(\mathrm{n}=41)$ and $\mathrm{V}(\mathrm{n}=44))$; soil moisture $(\mathrm{L}(\mathrm{n}=41), \mathrm{V}(\mathrm{n}=44), \mathrm{O}(\mathrm{n}=43)$, and $\mathrm{X}(\mathrm{n}=44))$; and soil temperature $(\mathrm{V}(\mathrm{n}=44)$ and $\mathrm{O}(\mathrm{n}=41))$.

${ }^{\mathrm{b}}$ Litter $\mathrm{Ca}, \mathrm{P}, \mathrm{Mg}$, and $\mathrm{K}$ not tested for significance.

${ }^{\mathrm{c}}$ Means in rows with different letters are significantly different $(p<0.05)$, based on Duncan's multiple range tests. 
Appendix XVb. Mean ( $\pm \mathrm{SE})$ values of invertebrate abundance, biomass $(\mathrm{mg})$, and microhabitat variables recorded under Morrow's honeysuckle shrubs (L), southern arrowwood shrubs (V), dense thickets of Morrow's honeysuckle (X), and open plots with no shrub cover (O) based on month at Fort Necessity National Battlefield, Pennsylvania, U.S.A.

\begin{tabular}{|c|c|c|c|c|}
\hline \multirow[b]{3}{*}{ Microhabitat variables ${ }^{\mathrm{a}}$} & \multicolumn{4}{|c|}{ Shrub type } \\
\hline & $L$ & $V$ & $X$ & $O$ \\
\hline & $\bar{X} \pm S E$ & $\bar{X} \pm S E$ & $\bar{X} \pm S E$ & $\bar{X} \pm S E$ \\
\hline \multicolumn{5}{|l|}{ May, $n=58$} \\
\hline Abundance (\#) & $22.0 \pm 1.7$ & $22.5 \pm 2.1$ & $9.0 \pm 1.5$ & $21.2 \pm 3.6$ \\
\hline Biomass (mg) & $13.0 \pm 2.3$ & $13.5 \pm 1.4$ & $7.7 \pm 1.6$ & $12.3 \pm 3.1$ \\
\hline Herb cover $(\%)$ & $50.2 \pm 5.6$ & $49.6 \pm 5.4$ & $34.1 \pm 5.3$ & $75.0 \pm 4.1$ \\
\hline Native cover: total cover (\%) & $48.5 \pm 6.9$ & $64.8 \pm 5.4$ & $39.4 \pm 5.9$ & $61.7 \pm 6.1$ \\
\hline Dry litter wt. (g) & $21.57 \pm 4.27$ & $30.99 \pm 5.35$ & $20.66 \pm 4.84$ & $17.16 \pm 3.01$ \\
\hline Litter N (\%) & $1.30 \pm 0.12$ & $1.49 \pm 0.08$ & $1.48 \pm 0.12$ & $1.22 \pm 0.07$ \\
\hline Soil moisture (\%) & $24.7 \pm 0.8$ & $24.7 \pm 0.7$ & $24.9 \pm 1.1$ & $23.3 \pm 0.7$ \\
\hline Soil temp. $\left({ }^{\circ} \mathrm{C}\right)$ & $15.0 \pm 0.3$ & $16.1 \pm 0.4$ & $14.8 \pm 0.3$ & $16.7 \pm 0.3$ \\
\hline Wet debris wt. (g) & $2.09 \pm 0.45$ & $1.99 \pm 0.22$ & $5.60 \pm 1.08$ & $0.62 \pm 0.09$ \\
\hline \multicolumn{5}{|l|}{ July, $n=50$} \\
\hline Abundance (\#) & $17.1 \pm 1.4$ & $14.7 \pm 1.4$ & $9.7 \pm 2.0$ & $17.9 \pm 2.8$ \\
\hline Biomass (mg) & $12.9 \pm 1.9$ & $11.0 \pm 1.8$ & $9.8 \pm 4.5$ & $15.9 \pm 5.0$ \\
\hline Herb cover $(\%)$ & $99.1 \pm 11.0$ & $106.8 \pm 10.5$ & $50.6 \pm 8.0$ & $155.5 \pm 11.7$ \\
\hline Native cover: total cover (\%) & $64.6 \pm 8.0$ & $68.3 \pm 8.1$ & $56.7 \pm 6.8$ & $72.8 \pm 7.8$ \\
\hline Dry litter wt. (g) & $13.06 \pm 3.99$ & $23.66 \pm 4.46$ & $17.10 \pm 3.37$ & $22.10 \pm 4.73$ \\
\hline Litter N (\%) & $1.07 \pm 0.12$ & $1.28 \pm 0.12$ & $1.23 \pm 0.12$ & $1.11 \pm 0.07$ \\
\hline Soil moisture (\%) & $19.9 \pm 1.14$ & $22.8 \pm 0.8$ & $21.6 \pm 0.7$ & $21.2 \pm 2.3$ \\
\hline Soil temp. $\left({ }^{\circ} \mathrm{C}\right)$ & $21.8 \pm 0.9$ & $20.4 \pm 0.4$ & $20.6 \pm 0.3$ & $22.9 \pm 0.6$ \\
\hline Wet debris wt. (g) & $1.03 \pm 0.16$ & $0.92 \pm 0.19$ & $2.86 \pm 0.52$ & $0.92 \pm 0.16$ \\
\hline \multicolumn{5}{|l|}{ August, $n=59$} \\
\hline Abundance (\#) & $9.1 \pm 1.1$ & $10.5 \pm 1.4$ & $9.1 \pm 2.3$ & $8.9 \pm 2.6$ \\
\hline Biomass (mg) & $18.5 \pm 5.5$ & $19.1 \pm 4.4$ & $7.9 \pm 2.6$ & $7.6 \pm 2.3$ \\
\hline Herb cover $(\%)$ & $61.3 \pm 6.2$ & $64.1 \pm 7.4$ & $46.0 \pm 7.4$ & $88.9 \pm 6.3$ \\
\hline
\end{tabular}


Appendix XVb. Continued.

\begin{tabular}{|c|c|c|c|c|}
\hline \multirow[b]{3}{*}{ Microhabitat variables $^{\mathrm{a}}$} & \multicolumn{4}{|c|}{ Shrub type ${ }^{6}$} \\
\hline & $L$ & $V$ & $X$ & $O$ \\
\hline & $\bar{X} \pm S E$ & $\bar{X} \pm S E$ & $\bar{X} \pm S E$ & $\bar{X} \pm S E$ \\
\hline Native cover: total cover (\%) & $75.4 \pm 3.4$ & $77.7 \pm 4.5$ & $58.0 \pm 7.4$ & $81.5 \pm 4.0$ \\
\hline Dry litter wt. (g) & $19.69 \pm 2.76$ & $40.68 \pm 4.92$ & $16.00 \pm 2.94$ & $27.84 \pm 4.71$ \\
\hline Litter N (\%) & $1.27 \pm 0.12$ & $1.53 \pm 0.11$ & $1.45 \pm 0.11$ & $1.13 \pm 0.09$ \\
\hline Soil moisture $(\%)$ & $14.2 \pm 0.5$ & $14.5 \pm 0.3$ & $13.6 \pm 0.4$ & $13.5 \pm 0.6$ \\
\hline Soil temp. $\left({ }^{\circ} \mathrm{C}\right)$ & $25.2 \pm 0.6$ & $25.3 \pm 0.7$ & $24.2 \pm 0.5$ & $26.2 \pm 0.5$ \\
\hline Wet debris wt. (g) & $2.35 \pm 0.27$ & $3.33 \pm 0.55$ & $3.31 \pm 0.51$ & $3.56 \pm 0.50$ \\
\hline
\end{tabular}

${ }^{\text {a }}$ Microhabitat variables correspond to model parameters in Table 1.

${ }^{\mathrm{b}} \mathrm{L}=$ single Morrow's honeysuckle shrubs; $\mathrm{V}=$ single southern arrowwood shrubs; $\mathrm{X}=$ dense thickets of Morrow's honeysuckle shrubs; and $\mathrm{O}=$ open plots with no shrub canopy. 
Appendix XVIb. $F$ and $p$ values of leaf herbivory metrics for Morrow's honeysuckle and southern arrowwood at Fort Necessity National Battlefield, Pennsylvania, U.S.A.

\begin{tabular}{|c|c|c|c|c|c|c|}
\hline \multirow[b]{3}{*}{ Dependent variables } & \multicolumn{6}{|c|}{ Independent variables } \\
\hline & \multicolumn{2}{|c|}{ Shrub type } & \multicolumn{2}{|c|}{ Month } & \multicolumn{2}{|c|}{$\begin{array}{c}\text { Shrub type } \times \\
\text { month }\end{array}$} \\
\hline & $\mathrm{F}^{\mathrm{a}}$ & $\mathrm{p}$ & $\mathrm{F}^{\mathrm{b}}$ & $p$ & $\mathrm{~F}^{\mathrm{b}}$ & $\mathrm{p}$ \\
\hline$\%$ w/evidence of herbivory & 154.56 & $<0.001$ & 49.61 & $<0.001$ & 8.89 & $<0.001$ \\
\hline Leaf area consumed & 18.31 & $<0.001$ & 5.40 & 0.006 & 2.90 & 0.061 \\
\hline Leaf rank & 139.30 & $<0.001$ & 51.94 & $<0.001$ & 9.94 & $<0.001$ \\
\hline
\end{tabular}

${ }^{a}$ Degrees of freedom/error df is $F_{[1,84]}$ for variables \% w/evidence of herbivory and leaf rank; df is $F_{[1,77]}$ for leaf area consumed.

${ }^{\mathrm{b}}$ Degrees of freedom/error df is $F_{[2,84]}$ for variables \% w/evidence of herbivory and leaf rank; df is $F_{[2,77]}$ for leaf area consumed. 
Appendix XVIIb. Mean ( \pm SE) leaf herbivory metrics based on shrub-month combinations at Fort Necessity National Battlefield, Pennsylvania, U.S.A.

\begin{tabular}{lcccc}
\hline & \multicolumn{2}{c}{$\begin{array}{l}\text { Percent } \\
\text { w/evidence of } \\
\text { herbivory }\end{array}$} & $\begin{array}{l}\text { Leafarea } \\
\text { consumed }\left(\mathrm{cm}^{2}\right)\end{array}$ & Leaf rank \\
\cline { 4 - 5 } Shrub-month & $n^{*}$ & $\bar{X} \pm S E$ & $\bar{X} \pm S E$ & $\bar{X} \pm S E$ \\
\hline $\begin{array}{l}\text { Morrow's honeysuckle } \\
\text { May }\end{array}$ & 15 & $1.5 \pm 0.5 \%$ & $0.12 \pm 0.06$ & $0.02 \pm 0.01$ \\
July & 15 & $13.2 \pm 2.8 \%$ & $0.13 \pm 0.02$ & $0.18 \pm 0.04$ \\
August & 15 & $8.9 \pm 3.1 \%$ & $0.11 \pm 0.06$ & $0.13 \pm 0.05$ \\
Southern arrowwood & 15 & $13.0 \pm 3.3 \%$ & $0.21 \pm 0.09$ & $0.14 \pm 0.03$ \\
May & 15 & $95.2 \pm 1.3 \%$ & $0.39 \pm 0.11$ & $1.34 \pm 0.07$ \\
July & 15 & $97.8 \pm 1.2 \%$ & $0.51 \pm 0.13$ & $1.45 \pm 0.07$ \\
August & & & & \\
\hline
\end{tabular}

* For leaf area consumed, $\mathrm{n}$ is as follows: Morrow's honeysuckle - May $(\mathrm{n}=13)$, July $(\mathrm{n}=15)$, August $(n=14)$; southern arrowwood - May $(n=12)$, July $(n=15)$, August $(n=14)$. 